\title{
Thermal Processing System Concepts and Considerations for RWMC Buried Waste
}

\author{
T. L. Eddy \\ P. C. Kong \\ B. D. Raivo \\ G. L. Anderson
}

Published February 1992

\author{
Idaho National Engineering Laboratory \\ EG\&G Idaho, Inc. \\ Idaho Falls, Idaho 83415
}


Thermal Processing System Concepts and Considerations for RWMC Buried Waste

EGG-WTD-10058

Prepared by:

$\frac{\text { Petal C. Kong }}{\text { P. C. Kong }} \frac{3-27-92}{\text { Date }}$
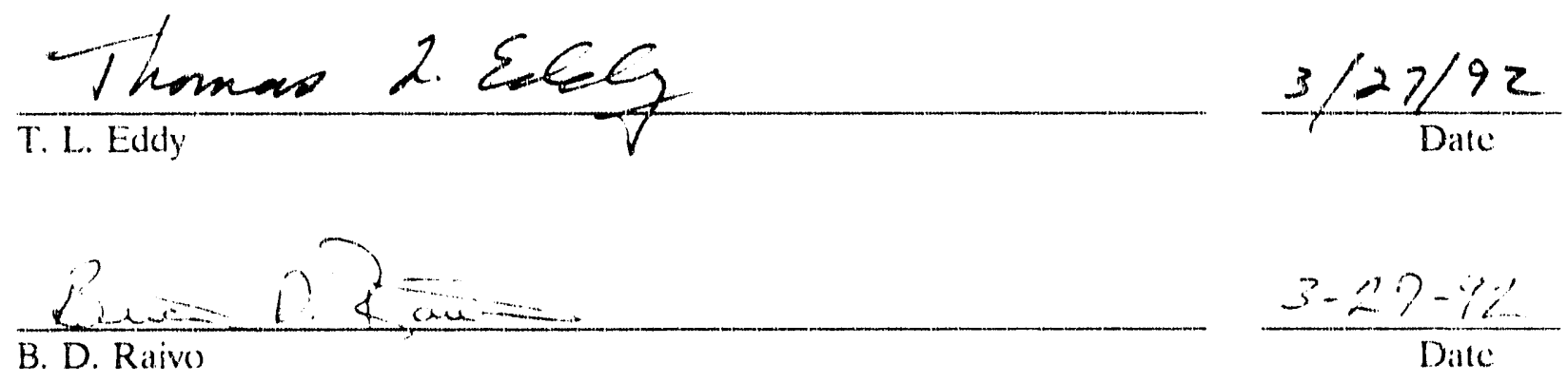

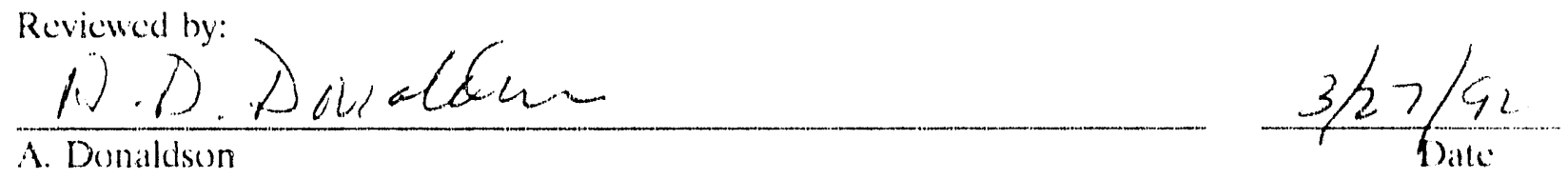

J. R. Weidner

Date:
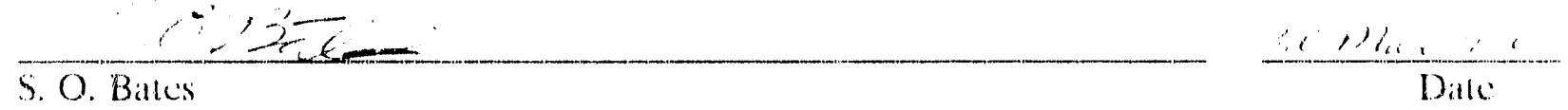

Reviewed and Approved by:

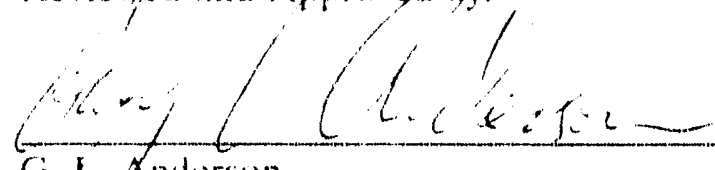

(i. 1. Anderson
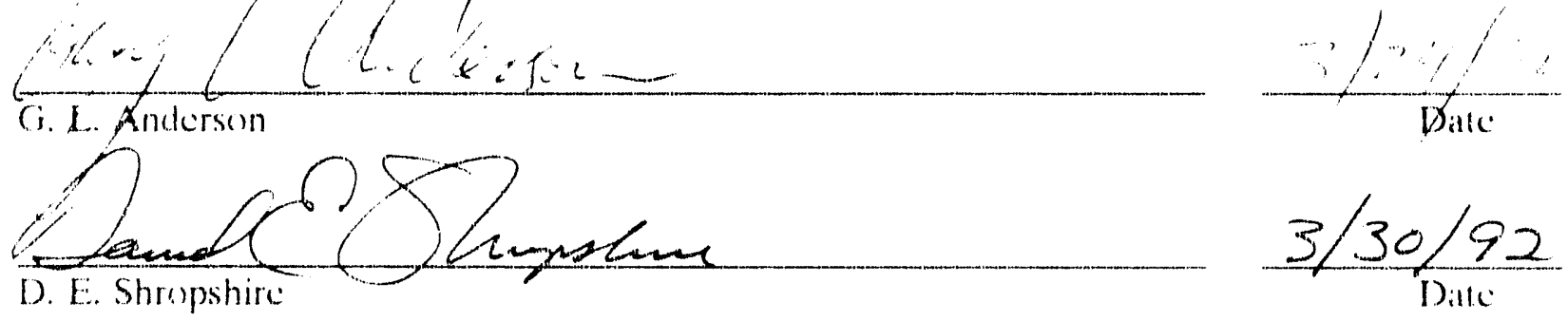


\begin{abstract}
This report presents a pretiminary determination of $\mathrm{ex}$ situ therral processing system concepts and related processing considerations for application to remediation of transuranic (TRU). contaminated buried wastes (TRUW) at the Radioactive Waste Management Complex (RWMC) of the Idaho National Enginecring Laboratory (INEL). Beginning with top-level thermal treatment concepts and requirements identified in a previous Preliminary Systems Design Study (SDS), a more detailed consideration of the waste materials thermal processing problem is provided. Anticipated waste stream elements and problem characteristics are identified and considered. Final waste form performance criteria, requirements, and options are examined within the context of providing a highintegrity, low-leachability glass/ceramic, final waste form material. Thermal processing conditions required and capability of key systems components (cquipment) to provide these material process conditions are considered. Information from closely related companion study reports on melter technology development needs assessment and INEL Iron-Enriched Basalt (IEB) research are considered. Five potentially practicable thermal process system design configuration concepts are defined and compared. A scenario lor thermal processirg of a mixed waste and soils streitm with essentially no complex presorting and using a series process of incineration and high temperature melting is recommended. Recommendations for applied research and development necessary to further detail and demonstrate the final waste form, required thermal processes, and melter process equipment are provided.
\end{abstract}




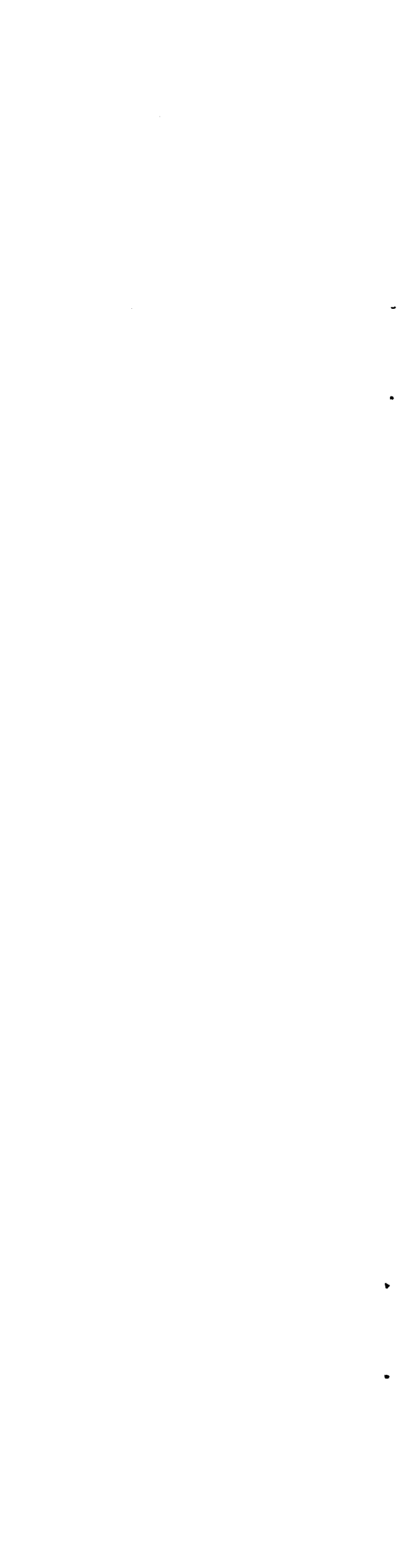

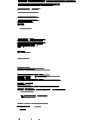




\section{FOREWORD}

This report was prepared for the Waste Technology Development Department of EG\&G Idaho, Inc., under contract to the U. S. Department of Energy Oftice of Technology Development Idaho Field Olfice. Funding was provided under FY.91 Thermal P oncessing Technologies Tecinical Task Plan ID-0502-DT, 1991, and ID-(04)E-2D, 1992.

This is one of a series of reports prepared for the Thermal Processing Technologies Project. Two other closely related reports in the series present a "Melter Development Needs Assessment," and "A Survey of INEL Research on the Iron-Enriched Basalt Waste Form."

Contributions to the report far exced the list of authors and reviewers. We appreciate the assistance of all those who contributed to this effort. 
1 


\section{CONTENTS}

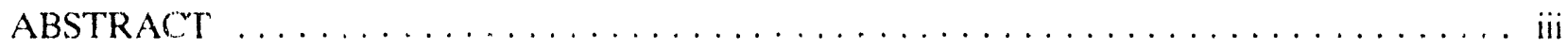

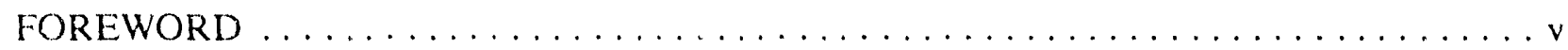

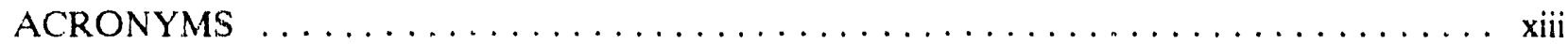

EXECUTIVE SUMMARY $\ldots \ldots \ldots \ldots \ldots \ldots \ldots \ldots \ldots \ldots \ldots \ldots \ldots \ldots \ldots$

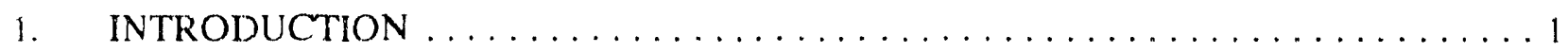

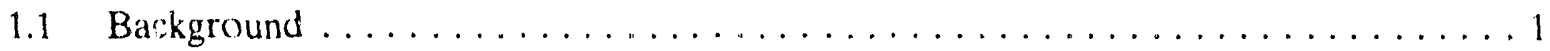

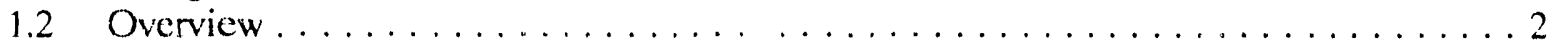

2. CLASSIFICATION OF INPUT WASTE STREAMS $\ldots \ldots \ldots \ldots \ldots \ldots \ldots \ldots$

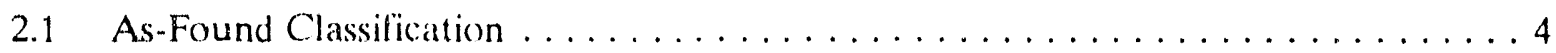

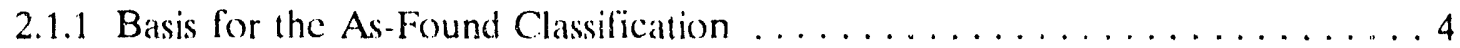

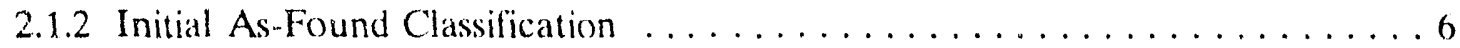

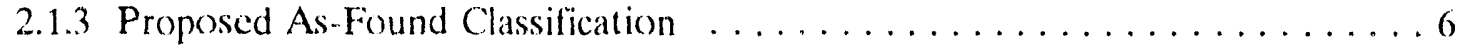

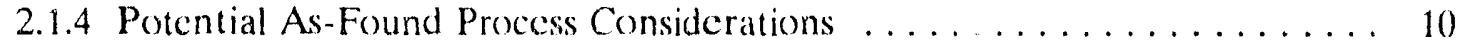

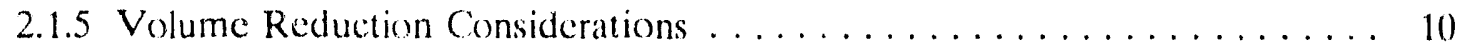

2.2 As-Separated Classilication $\ldots \ldots \ldots \ldots \ldots \ldots \ldots \ldots \ldots \ldots \ldots \ldots$

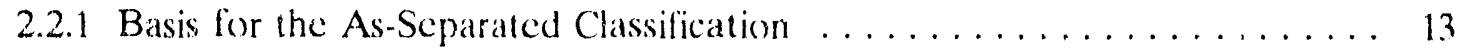

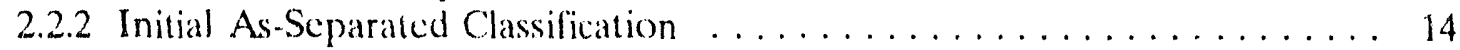

2.2 .3 Potential As-Separated Process Considerations . . . . . . . . . . . 14

2.3 Recommended Classification of Waste Streams . . . . . . . . . . . . . 18

3. CRITERIA AND REQUIREMENTS FOR FINAL WASTE FORM $\ldots \ldots \ldots \ldots$

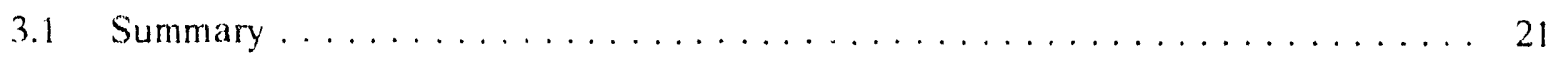

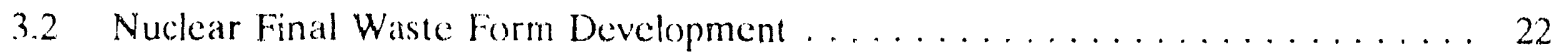

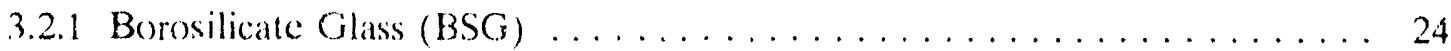

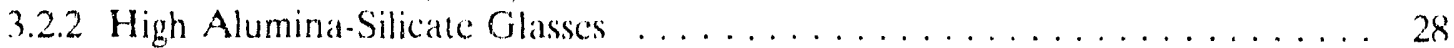

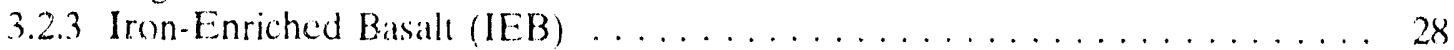

3.2 .4 Glass-Ceramics . . . . . . . . . . . . . . . . . . . . . . . .30

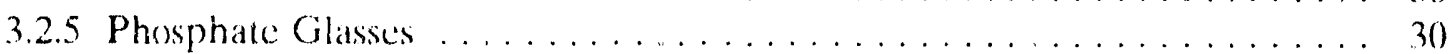

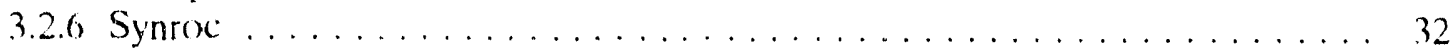

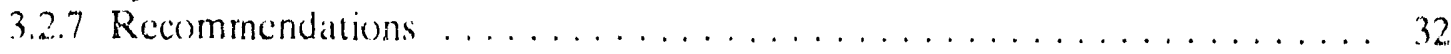


3.3 Criteria for RWMC TRU Final Waste Form

3.3.1 System Design Study Generalized Criteria $\ldots \ldots \ldots \ldots \ldots \ldots \ldots \ldots . . \ldots 3$

3.3.2 Desirable Final Waste Form Characteristics and Criteria $\ldots \ldots \ldots \ldots \ldots 33$

3.4 Final Waste Form Evaluation $\ldots \ldots \ldots \ldots \ldots \ldots \ldots \ldots \ldots \ldots \ldots \ldots$

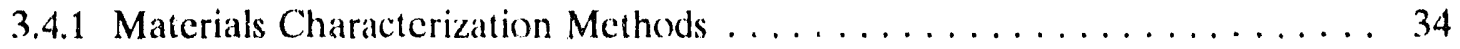

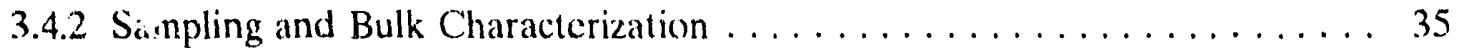

3.4.3 Chemicai, Phase, and Morphological Analyses ............. 3.5

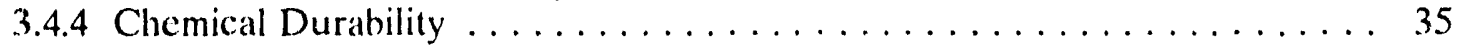

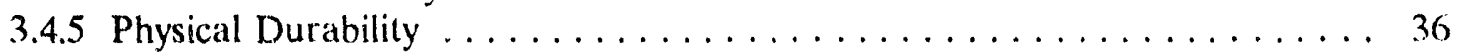

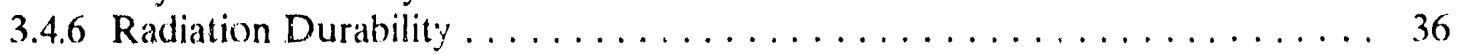

3.4.7 Proposed Waste Form Characterization Methods for Tests . . . . . . . . 37

4. WASTE STREAM PROCESSING $\ldots \ldots \ldots \ldots \ldots \ldots \ldots \ldots \ldots \ldots \ldots$

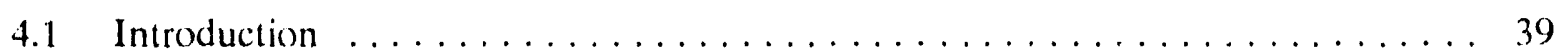

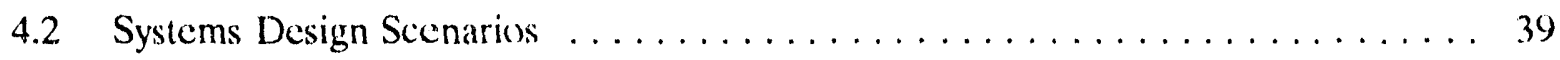

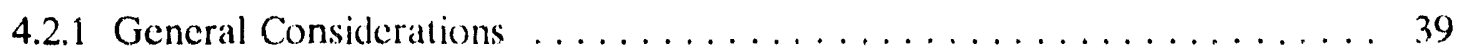

4.2 .2 The SDS Scenario . . . . . . . . . . . . . . . . . 42

4.2.3 The Simple Retrieval and Burden Soil Separation Scenario . . . . . . . . . 49

4.2.4 The SDS Retrieval and Total Soil Separation Scenario . . . . . . . . . . . 56

4.2.5 The SDS Retricval and Soils Processing Scenario . . . . . . . . . . . 56

4.2.6 The Borosilicate Glass Scenario ... . . . . . . . . . . . . 61

4.2.7 Comparison of Seenarios and Options and Recommendations . . . . . . . 61

4.3 Radiological Assays $\ldots \ldots \ldots \ldots \ldots \ldots \ldots \ldots \ldots \ldots \ldots \ldots \ldots \ldots$

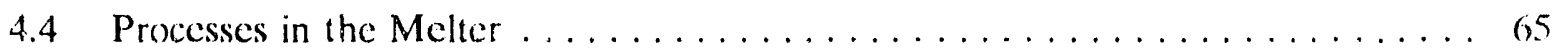

4.4.1 Physical Processes in the Melter . . . . . . . . . . . . . . . . 65

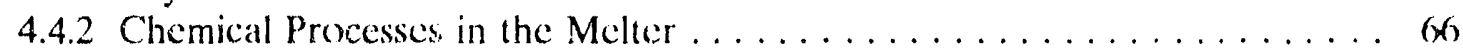

4.4 .3 Vitrification/Devitrification Processes in Slag . . . . . . . . . . . . 69

4.5 R\&D to Optimize the Waste Form and Processes . . . . . . . . . . . . 69

4.5.1 Recommended R\&D and Priorities $\ldots \ldots \ldots \ldots \ldots \ldots \ldots \ldots \ldots \ldots$ 70

4.5.2 Proposed Testing . . . . . . . . . . . . . . . . . . . . . . . . . . . . 71

4.5 .3 Potential Collaborators to Solve Problems . . . . . . . . . . . 72

5. FIRST TEST SERIES RESULTS $\ldots \ldots \ldots \ldots \ldots \ldots \ldots \ldots \ldots \ldots \ldots$

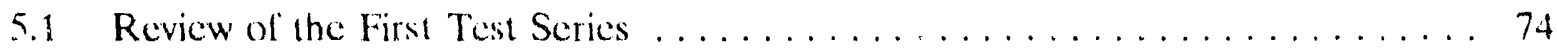

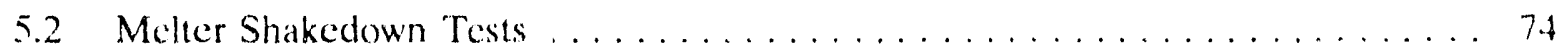

5.3 Scientific Experiments ......................... 75 
6. CONCLUSIONS AND RECOMMENDATIONS $\ldots \ldots \ldots \ldots \ldots \ldots \ldots \ldots$

6.1 Input Waste Streams $\ldots \ldots \ldots \ldots \ldots \ldots \ldots \ldots \ldots \ldots \ldots \ldots \ldots$

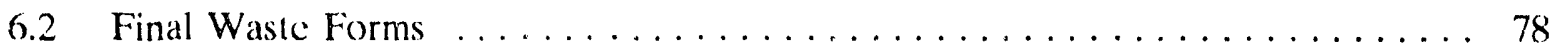

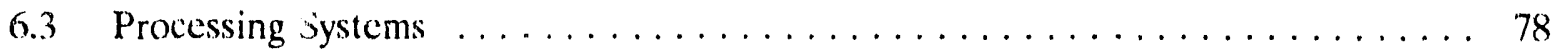

6.4 Recommended $R \& D \ldots \ldots \ldots \ldots \ldots \ldots \ldots \ldots \ldots \ldots \ldots \ldots \ldots$

7. REFERENCES $\ldots \ldots \ldots \ldots \ldots \ldots \ldots \ldots \ldots \ldots \ldots \ldots \ldots \ldots \ldots \ldots \ldots$

Appendix A-Source Data for Waste Streams and Scenarios $\ldots \ldots \ldots \ldots \ldots \ldots \ldots$ A-1

Appendix B-Materials Characterization Methods $\ldots \ldots \ldots \ldots \ldots \ldots \ldots \ldots \ldots$

FIGURES

S-1. A conceptual, not-to scale incineration and melting system with no sorting (other than Special Case) $\ldots \ldots \ldots \ldots \ldots \ldots \ldots \ldots \ldots \ldots \ldots \ldots \ldots \ldots \ldots \ldots$

S-2. An approximate mass flow diagram of input waste streams and output

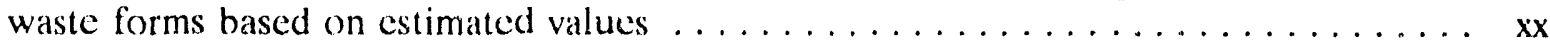

S-3. Relative mass (left) and volume (right) fractions of the TRUW, entrained soil, underburden soil and overburden soil for Pit 9. Areas are similar because mean specific gravities are approximately two $\ldots \ldots \ldots \ldots \ldots \ldots \ldots$ xii

S-4. Scenario II-E, the most highly recommended incineration and melting system scenario $\ldots \ldots \ldots \ldots \ldots \ldots \ldots \ldots \ldots \ldots \ldots \ldots \ldots \ldots \ldots \ldots \ldots \ldots \ldots$

S.5. Illustration of the effect of adding flux to the slag melt $\ldots \ldots \ldots \ldots \ldots \ldots \ldots$ xix

2-1. A schematic overview of the iniajor storage activities at RWMC related to this work . . . 5

2-2. Relative mass fractions of material categories of Pit $9 \ldots \ldots \ldots \ldots \ldots \ldots$

2-3. Component waste streams for As-Separated classification based on the

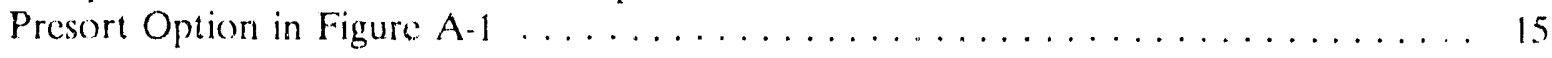

2-4. Preliminary process thow diagram of matcrial categories within waste streams to indicate the probable types of processing needed $\ldots \ldots \ldots \ldots \ldots \ldots \ldots 17$

3-1. Historical development of the nuclear final waste forms $\ldots \ldots \ldots \ldots \ldots \ldots \ldots$

3.2. Tolerance range of major oxides in IFP $\ldots \ldots \ldots \ldots \ldots \ldots \ldots \ldots \ldots \ldots \ldots \ldots$

4-1. Scenario I-SDS process incincration and melting system with L.L.W

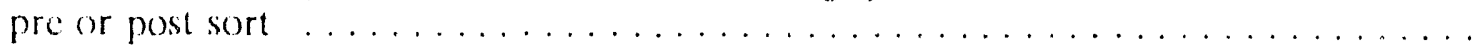


4-2 Conceptual sketch of electrically-heated melters: (a) Jouk-heated melter with the immersed electrodes in the horizontal configuration, (b) an are-heated melter with 3-phase AC operation and graphite electrodes, and (c) a plasma-heated melter with 1-phase DC operation and both electrodes in the torch $\ldots \ldots \ldots \ldots \ldots$

4-3. The INEL. Joule-heated melter with molybdenum electrodes used for IEB rescarch

4-4. Plasma-heated melter torch-clectrode configurations: (a) transferred-arc torch with the melt as the cathode and (b) nontransferred-are torch with both electrodes in the torch

4-5. Plasma-heated melter used in the INEL PAFE experiment in the transferred-arc mode with 1-phase DC operation, metal electrode torch, an oxygen lance, and water-cooled skull with a rotating chamber that is slowed to pour the slag

4-6. Scenario II-A - Combined Incineration and Melting System with Simple Retrieval and over/under burden soil separation from the treated waste stream. Option A - no sorting other than Special Case

4-7. Scenario II-B - Separated Incineration and Melting System with Simple Retrieval and over/under burden soil se aration. Option B - Sorting

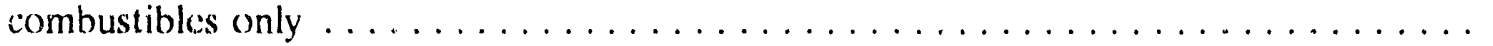

4-8. Scenario II-C - Separated Incineration and Melting System with Simple Retrieval and over/under burden soil separation. Option C - Sorting combustibles, noncombustibles (including entrained soil), and metals.

4-9. Scenario II-D - Separated Incincration and Melting System with Simple Retrieval and over/under burden soil separation. Option D - Sorting metals only

4-10. Scenario II-E - Separated Incineration and Melting System with Simple Retrieval and over/under burden soil separation. Option E - No sorting other than Special Case. Also includes the air-plant and zeroemissions options.

4-11. Scenario III - Scenario II options but including the SDS Retrieval Subsystem and total soil separation.

4-12. Scenario IV - Scenario II options but including the SDS Retrieval Subsystem, total soil separation, and the SDS Soil Processing Subsystem.

4-13. Scenario V - Secnario II options but including the SDS Retrieval Subsystem, total soil separation, SDS Soil Processing Subsystem, and with a Borosilicate Glass linal waste form.

4-14. Types of and requirements for radiological assays al various stages in the generic processing scenario 
5-1. Microphotographs of the slag waste form from the PEC, ACT, and RWMC tests $(1000 \mathrm{X})$. The PEC slag is predominantly amorphous glass. The RWMC slag is predominantly crystalline rock . . . . . . . . . . . . . . .

\section{TABLES}

S-1. Material categories identified and estimated quantitics in each of the major waste streams $\ldots \ldots \ldots \ldots \ldots \ldots \ldots \ldots \ldots \ldots \ldots \ldots \ldots \ldots \ldots \ldots \ldots$

S-2. A qualitative comparison of the properties of various glasses

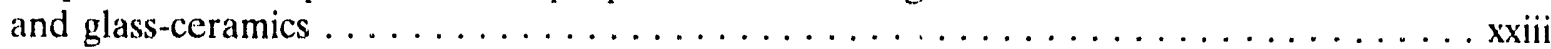

S-3. Processing options for using various Joule-heated and plasma-heated melters to make different viable waste forms . . . . . . . . . . . . . . . .

2-1. Preliminary tabulation of materials found in buried waste in

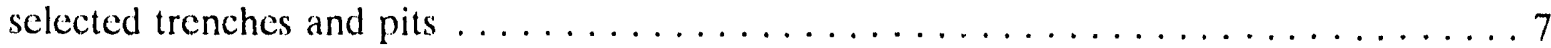

2-2. Proposed As-Found classification of input waste streams. Mass/Volume

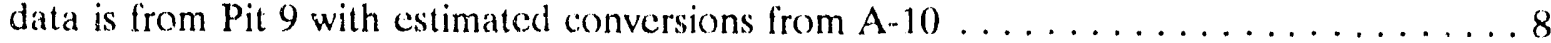

2-3. Expected potential problems and possible fixes for the various material categories of the input waste streams. Note that all substances may have radiation-hazard problems. Most of the reaclive materials and radionuclides should be in the oxide state

2-4 Various volumes and calculated volume reduction or compaction ratios for

Pit 9 based on estimated volumes and masses

2.5 Initial As-Separated classification of input waste streams. Mass/Mole data is for Pit 9 as estimated from Tables A-10 and A-11. Pit 9 has no record of LLW from the INEL. The basis for the molecular weight is given in parenthesis.

2-6. Recommended As-Separated classification of input waste streams . . . . . . . . . 20

3-1. Desirable final waste form characteristics $\ldots \ldots \ldots \ldots \ldots \ldots \ldots \ldots \ldots \ldots \ldots$

3-2. Desirable process considerations for waste form development $\ldots \ldots \ldots \ldots \ldots \ldots \ldots$

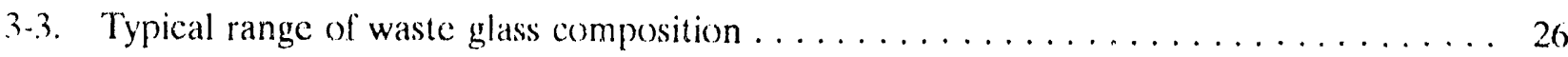

3.4 Characteristics of different waste forms compared to BSG $\ldots \ldots \ldots \ldots \ldots \ldots \ldots$

3-5. Cation size indices and valency for icnic exchange reaction $\ldots \ldots \ldots \ldots \ldots \ldots$

3-6. Summary table of chemical, irradiation, and mechanical durability tests for the final waste forms 
4-1. Summary of the options included in the system design scenarios $\ldots \ldots \ldots \ldots \ldots \ldots$

4-2. Comparison of input sorting Options $A, B, C, D \& E \ldots \ldots \ldots \ldots \ldots \ldots$

4-3. Potential researchers and collaborators to solve problems $\ldots \ldots \ldots \ldots \ldots \ldots \ldots$ 


\section{ACRONYMS}

$A C T$

BSG

CDIF

CERCLA

CFR

DOE

DOT

EAF

EPA

HLWW

HVPM

IEB

INEL.

ISV

JHM

I.DR

I...

I.I.W

MAP

MIFP

MSDS

NRTS

PAFE

PCR

PlAM

PiL

R\&D

RCRA

RFP

RWM

प)

-1)

>til.

IPI

TRA

TRAMPAC

TRE

IRI H

ISA

1.5819

Iscis

WIPP

MM

WTDD

MSEP afterburn component test

borosilicate glass

Component Development Integration Facility

Comprehensive Environmental Response, Compensation, and Liability Act

Code of Federal Regulations

Department of Energy

Department of Transportation

electric are furnace

Environmental Protection Agency

bigh-level waste

high vapor-pressure metals

iron-enriched basalt

Idaho National Engineering Laborytory

in situ vitrification

Joule-healed muller

land disposal restrictions

low-level radionuclides

low-level waste

mixed activation proctuct

mixed lission product

materiat sitcety datas sheet

National Reactor Testing Station

plasma arc lumace experimernt

plasmit centrifugal reactor

plasma-heated melle"s

Pacilic Rorthwest Lathoratary

researsh and dewelopment

Resource Consenation and Recovery Act

Rocky Fats Plant

Raduactine Waste Management Complex

Subsurface Disposal Arcai

Preliminary System Dewign Study Report (Red 1)

Satarath Rower Laboratory

thermal precessing kechnologies

Tese Reactur Areat

DOT nuclear saste transportation requirements

transuratnis

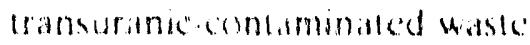

Tranourance Storitge Areat

1:S. Burcatu of Mince

IS. Congoged Sures

Waste Guthern Pikn Plant

Waste Mathatement Department

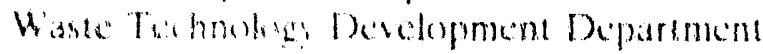

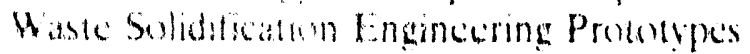




\section{EXECUTIVE SUMMARY}

\section{Introduction}

Beginning with results from existing preliminary systems design scudies (SDS), the work reported here provides the next level of preliminary conceptual design determination for thermal treatment-based processing of Idaho National Engineering Laboratory (INEL) buried wastes. Transuranic (TRU)-contaminated buried wastes at the Radioactive Waste Management Complex (RWMC) Subsurface Disposal Area (SDA) require remediation via the Comprehensive Environmental Response, Compensation, and Liability Act (CERCLA) decision process in order to remove the INEL from the National Prioritics List (NPL) of the Environmental Protection Agency (EPA). The buried wastes and contaminated soils represent a highly heterogencous mixture of combustibles and noncombustibles contaminated with Resource Conservation and Recovery Act (RCRA)-listed and characteristic hazardous materials and TRU radionuclides. Based upon the sysiem design studies, proposed thermal prow....ing concepts involve incineration for combustion climination of hazardous organics and melting/vitrilication for stabilization of the hazardous nonconbustibles and TRU elements as a long-lived glass ceramic final waste form.

In particular, this study focuses on a determination of the melting/vitrification process condition and enabling technologies within the context of developing a total thermal systems application to the RWMC buried wastes. Development of a processing system requires determitation of the incoming waste materials to be processed, determination of the output product material performance required, and an iterative design match of available and improved process systems technology components (equipment) capabilities to the desired process parameters.

As an example, a conceptual incincration and melting system with no sorting (other than a bulk presort of Special Case waste items) is illustrated in Figure $S-1$ and is briefly described in the following. A simplified retrieval system is located in a temporary alpha containment building located wer the pit to be excavated. An overhead crane is available to relocate oversized or highly ratdioactive items. The manually-operated backhos is shicked and is used for loading drums, containers, and soil into sealable bins on conveyor belts. The bins are sealed, assayed for content, and transported to the processing building where they are routed into the appropriate order or feed line to be empticd into the sizing unit.

The entire thermal processing system from the sizing unit on through the offgas treatment system exhaust and the waste form packaging unit is enclesed for alpha containment. After sizing, the unsorted waste goes through a thermal desorption process to initiate decomposition of volatile organies at low temperature, then to the incinerator to initiate combustion/pyrolysis and to preheat noncombustible solids in the waste stream. The gascous products of incomplete combustion from the incinerator are routed to an afterburner to ensure complete combustion of hydro carbons (the afterhurner provides residence time and lemperature to ensure complete destruction of dioxins and wher potential intermediate loxic hydrocarbons). Olfgases from the melter also go to the afterbumer. The offgas treatment system removes any volatilized metals and metal oxides, halogen and sulfur compounds, (acid gases) and other precipitable compounds. These will be later treated at at sceondary waste stream, as necessary. The exhiust gases to the atmosphere are elean carbon dioxide, water vapor, and nitrogen that meet EPA and State air pollution requirements.

The noneombustible solids from the incinerator are led into the melter by a serew conveyor in a semicontinuous mode with periends of 10 to 30 minutes. The solids temperature out of the 


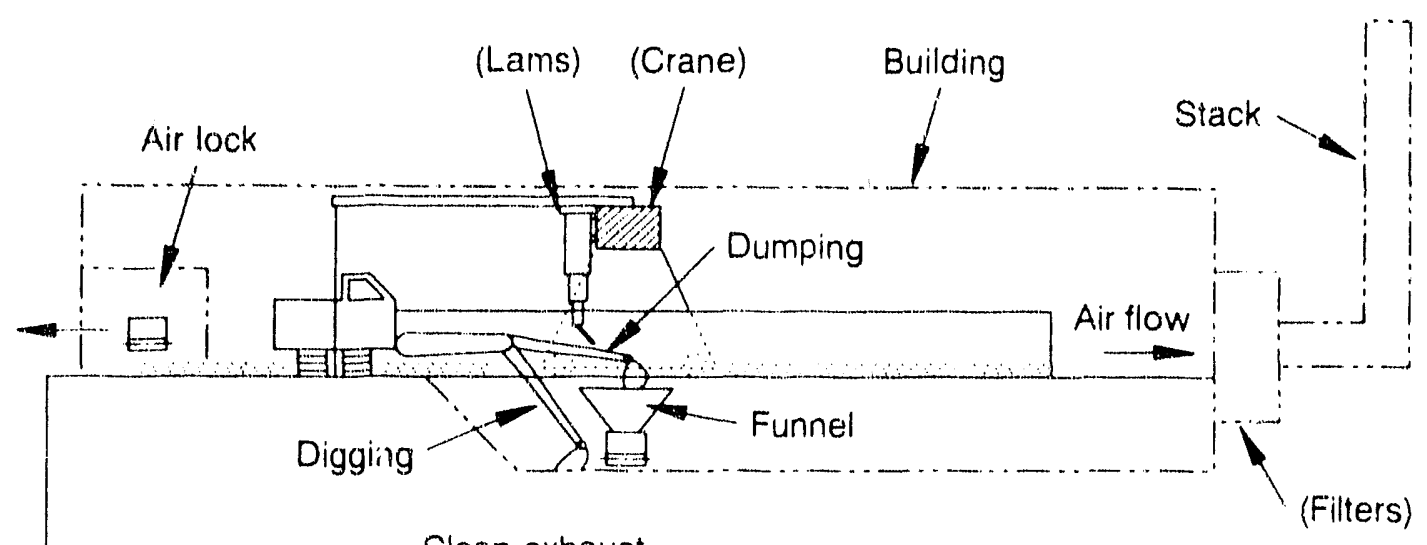

Clean exhaust

Filters)

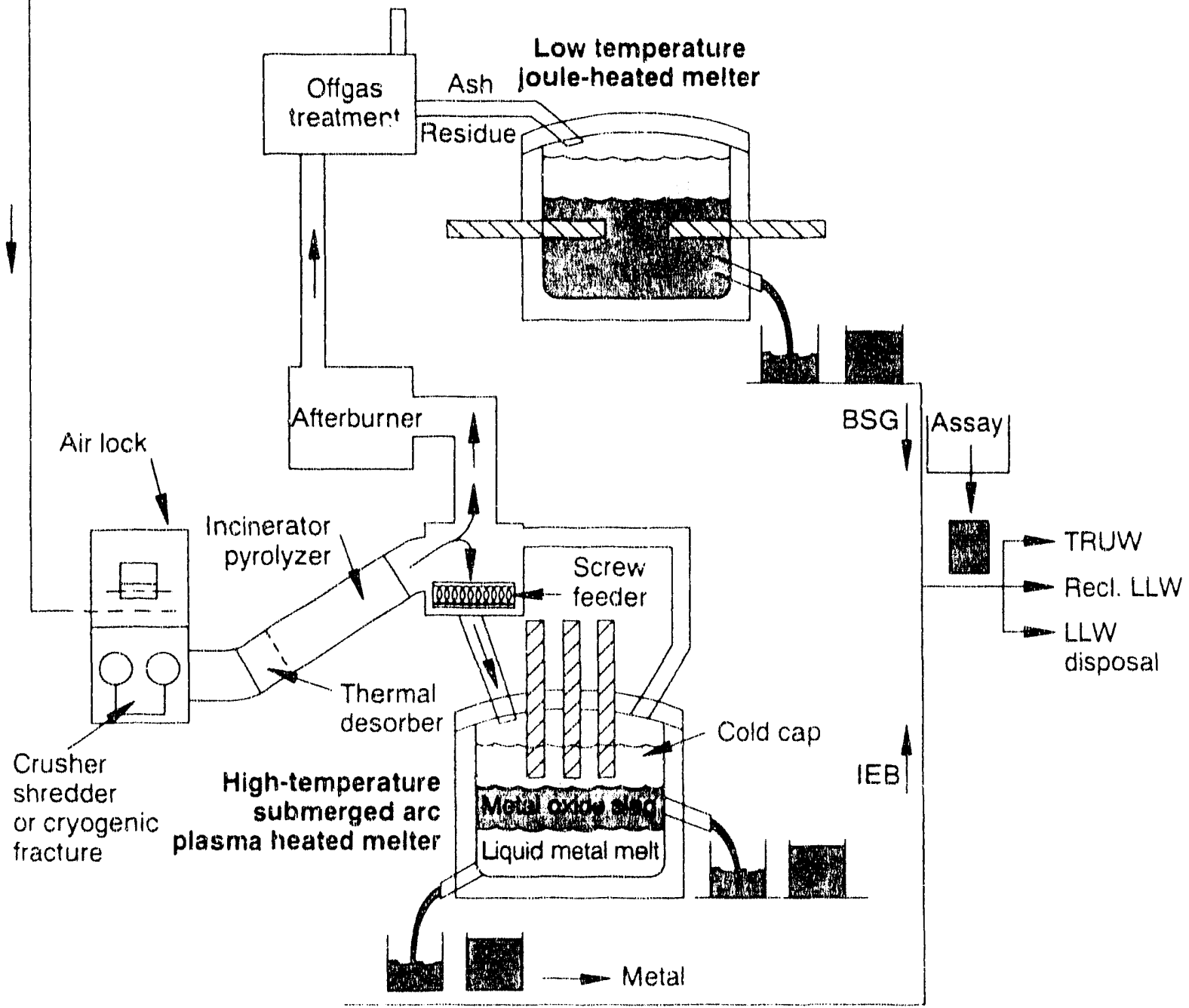

N92 0026

Figure S-1. A conceptual, not-to scale incineration and melting system with no sorting (other than Special Case). 
incincrator/pyrolyzer must be controlled to minimize agglomeration and corrosion in the screw conveyor. In the melter, the new solids (feed burden) are anticipated to form a cold cap over the: slag melt which may help to inhibit loss of the high vapor pressure metals and their oxides. The middle layer in the meller is the molten slag composed of silica and metallic oxides that will yield the tinal waste form elemental composition. The lower layer is a molten metal bayer decontaminaled of TRU and low-kevel waste (LLW) nuclides (heavy metal oxides are retained in the slag). Natural convection currents in the slag promote mixing for the desired reactions and homogencity. The melter configuration shown is a 3-phase, AC graphite electrode submerged-arc melter. Other types and conligurations of melters are possible (DC arc, plasma torch, etc.). Periodically, e.g., every 10) to 30 minutes, a barrel of liquid metal (mostly iron) is tapped and packaged for LLLW disposal or possible reclamation depending upon activity level. Al similar periods, one or more barrels of slag are tapped, packaged, cooled under a controlled schedule of form the desired glass/ceramic, assayed, and routed to the appropriate TRUW, reclassitied LLW, or LLW temporary storage prior to permanent disposal. Melter operating procedures would generally follow these which have heen in practice in the scrap melting and smelting industry for decades, with modification to ensure alpha control.

The secnario described is provided as a representative example at this point, intended to give the reader some understanding of an overall thermal processing system approach. "The following sections summarize the waste stream, linal waste form, and thermal processing scenario considerations.

\section{The Input Waste Stream}

Buried waste materials have been examined in this study from the standpoint of representing potential input waste streams for thermal processing. This has included delermining what type and amount of materials are likely to be processed, which materials may constitute potential problems, possible process problem resolutions, whether sorting is needed or advantageous, and how these lactors alfect melter design and internal processing.

Existing information on SDA waste and contaminated soils was examined to identily probable input material streams for thermal processing. Two preliminary design-based waste stream dassilications have heen delined for subsequent thermal processing considerations in this study. An "As Found" waste stream classilication is estahlished which essentially represents a mix of all the waste materials present to be processed without separation; while an "As Separated" waste stream classification groups the wastes into separate waste streams for processing (combustibles, nencombustibles, and bulk metals). Contaminated soils are considered as a separate input material category on be processed along with the wastes.

The TRUW is buried in Thenches $1-10$ and Pits $1-69$ and 10 of the SDA at RWMC. Detailed mlormation is availathe for Pit 9, with other pits and tereches expected on have similar types of materiais. Major input waste sticams defined for processing in the SDS were metals, combustibles, noncombustibles, and sovils. Table S-1 lists the material calcegories identilied and provides estimated quantities lor eatch of these major streams based upon available data. Special case wastes (oversized objects, compressed gas cylinders, highly radioactive wastes, efe.) are to be separated out prior to thermal processing and trated separately. All remaining waste is to be sized by crushing, shredding. cryegenic fracture, or equivalent to approximately 2 in. dimensions. 
Table S-1. Material categories identified and estimated quantities in each of the major waste streams.

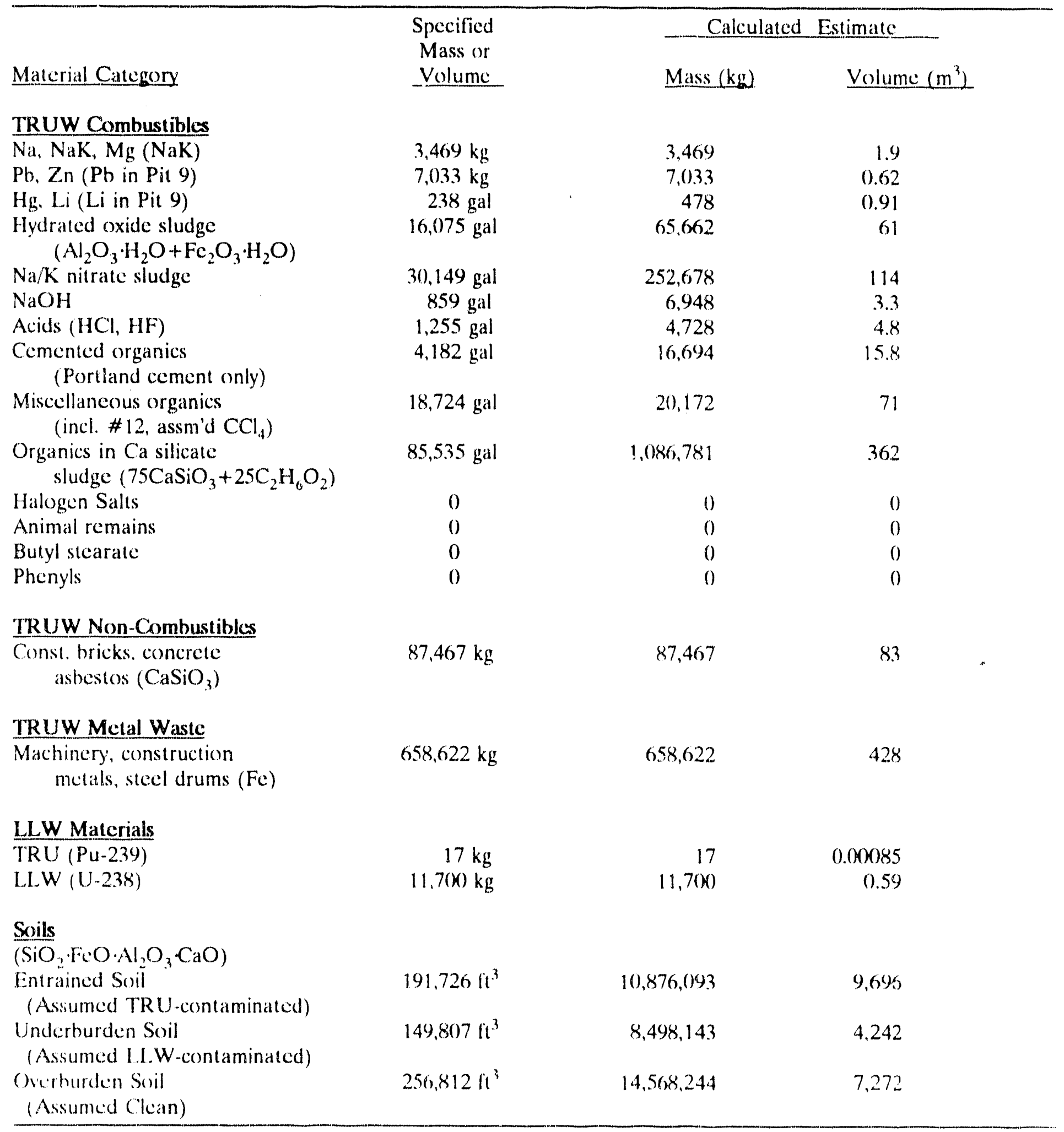


For the "As Separated" case, consistent with the System Design Study (SDS), combustibles are to be routed to an incinerator with the noncombustible solid residues (ash) then routed to the melter. The contaminated soils waste stream is assumed processed by the SDS Soils Processing Subsystem, or equivalent, to separate clean, low-level, and TRU-contaminated soils, with at kast the TRU. contaminated soil routed to the melter. The metals waste steam may be muted through the SDS Metals Decontamination Subsystem, or routed to the primary meler/vitrilier to be surfate oxidized or decontaminated by melting in the high-temperature $\left.(15)(1)-18(0){ }^{\circ} \mathrm{C}\right)$ oxidizing melter (iron melts at $1538^{\circ} \mathrm{C}$ ). Any remaining melted metal could be tapped and packaged as L.LW (or ckean material depending upon activity level).

When mixed with soil, most of the organies, acids, base's, and reactive metals are buffered and not expected to represent significant thermal processing problems. In the melter environment, complex chemical compounds will be decomposed inco oxides in the slag or produce pyrolized gases. Some compounds (nitrates, cemented organics, hydrated oxides, ete) in large quantities could lead 6) rapid gas generation in the melter and should be sized and thermally decomposed before entering the melter. In particular, the nitrales are strong oxidizing agents, are very reactive at higher temperatures, and would be best roasted at modest temperature to convert to Na/K oxides and NOn. Noncemented organics and toxic materials should be mixed with soil. combusted, and the ash vitrified. High vatoor pressure (volatile) metals (HVPMs) such as $\mathrm{Pb}, \mathrm{Zn}, \mathrm{Hg}, \mathrm{Cs}-137$. etc., are expected to be oxidized and refurned to some extent to the slag with transported metal vapors collecled downstream in the offgas system for later treatment, e.g. vitrify at lower cemperature. The exhaust gases to atmosphere would be air, water vapor, and carbon disoxide meeting EPA and State requirements.

It will probably be difficult 10 accurately and thoroughly identify the contents of the various incoming barrels, so a more appropriate precess solution may be to combine all waste materials with sullicient soil to yield an oxidizing, fucl-laden soil which can be processed in a rotary kiln or rquivalent incinerator. The noncombustible residue, preheated by its own encergy souree, goes to the meler. All TRU and low kevel (LL) radioactive materials will be oxidized and dissolved in the slag and almoss all is expected 10 be retained in the slag. The extent of volatilization of any TRU/L.L materials will be process dependent and needs $t o$ be addressed experimentally to ensure expected retention in the slag. Available assaying kechnology and procedures are assumed to be adequate for safety and material process control purposes. Some application development in this area may be needed.

Figure S-2 shows an approximate mass llow input output diagram hatsed on estimated input waste stream quantities and assumed compositions for the non-sonced As Found case. Though approximate, it gives a rough idea of the relative amounts of different waste materials to be processed. The bulk of the waste stream is calcium silicate containing organics $(25 \%)$, sodium and potassium nitrates, and metals (mostly steed not including the drums). The oxven required to combust the organics is relidively large because of the low atomic weights of $\mathrm{C}$ and 11 . The amount of oxygen required for oxidation of the metal has been reduced from the theoretical total by assuming $30 \%$ of the metal is oversize and sorted wut, $55 \%$ is tapped as pure reduced meled metal, and only the remaining 158 in surface oxidized 10 remove contaminants. The exhatust gats effluent volume that will result is appreximatcly 10 (no times smaller than that from a boiler in a typical electri power plant. In this "average" composition scenario, no soil is added. If soil is added, the final wane form mass will increase by the amount of soil added. Soil would be added to provide problem-material bulfering and to aceount for variations in :he no-sort composition. It is also expected that contraned soil may be difficult to separate from the wastes. 


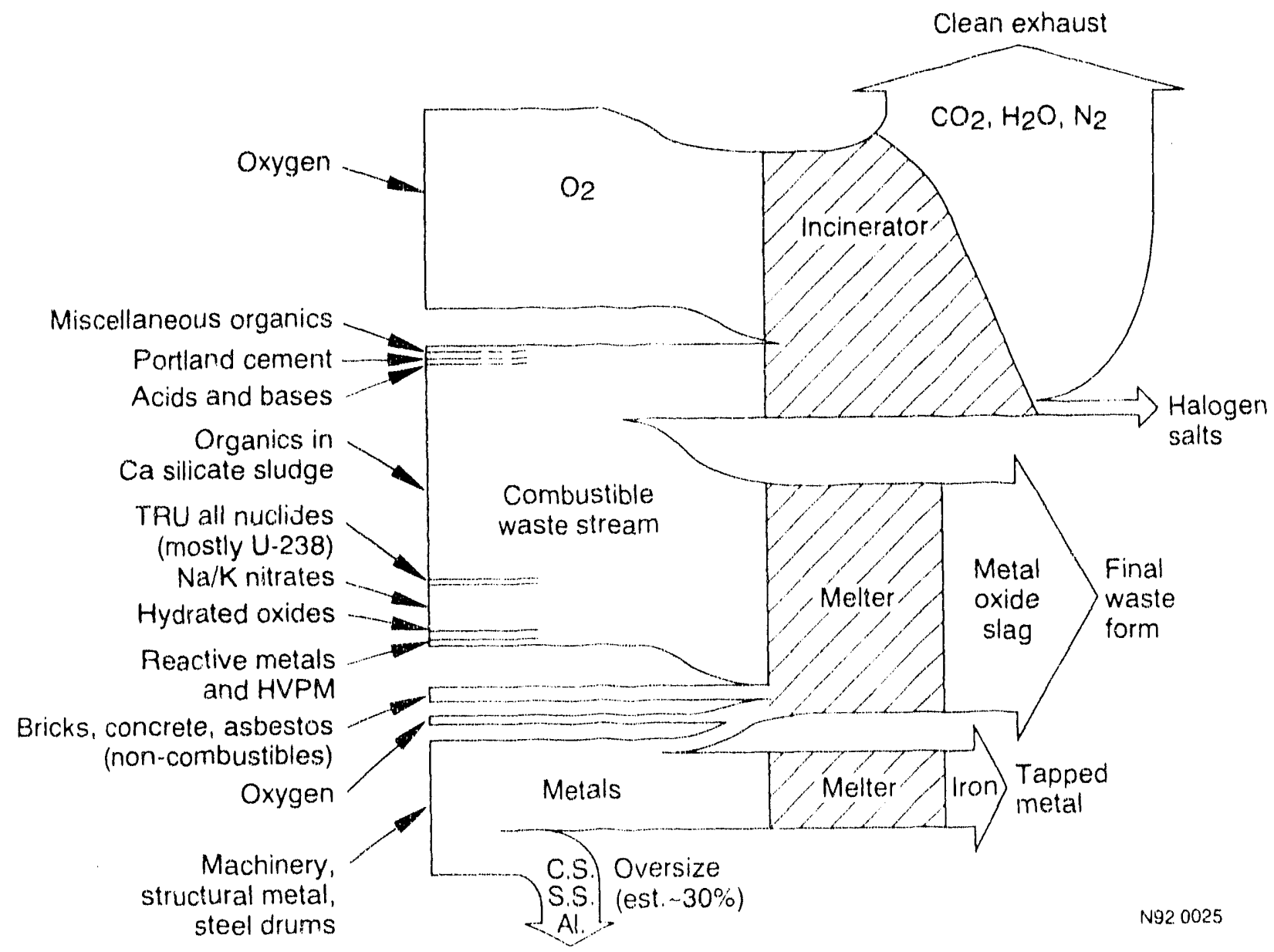

Figure S-2. An approximate mass flow diagram of input waste streams and output waste forms based on estimated values. 
It should be noted that the potentially contaminated soil input stream to be thermally processed is from three to nine times that of the mass or volume of the buried wastes, as shown in Figure S-3 The estimated waste and soil volumes have been used to estimate the potential waste volume reduction resulting from vitrification. The compaction ratio for the waste stream, excluding soil, is about 4/1. If the net soil entrained among the containers is adled to the waste, the compaction ratio is almost 3/1. Using only soil (processing only soil and no waste) would produce at reduction ratio of about $1.6 / 1$. Heterogeneity in as-retrieved waste stream composition in a no-sort scenario will likely vary the soil fraction from $0-60 \%$, in which casc the mass of entrained soil would be more than adequate to provide for buffering in the process and produce the desired final waste form for a wide range of input waste composition. The resulting total compaction ratios should then be between $2 / 1$ and $3 / 1$.

\section{The Final Waste Form}

Based upon the preliminary SDS, the preferred final waste form is a highly leach-resistant, ghass/ceramic solid that will meet or exceed all current Waste Isolation Pilot Plant (WIPP) Waste Acceptance Criteria (WAC) and EPA land disposal restriction (LDR) criteria. The determination of the desired composition and performance characteristics of the final waste form product is necessary to establish the materials thermal processing conditions and technology to be used. Various ylassicera ric waste form materials have been considered, compared with the waste stream composition, and a recommendation made for the use of a form of iron-enriched basalt (IEB).

In examining possible glass/ecramic host solids for the stabilization and immobilization of buried TRU mixed wastes, this study has considered the phosphate, borosilicate (BSG), and high aluminasilicate glasses, as well as the iron-enriched basalt, Synroc, and other glass-eeramics. The glassy forms are amorphous (or vitrified), have physical features like window glass or pyrex, and may be translueent or opaque. The ceramics are mostly crystalline (devitrified or rock-like) and have physical fattures like river rock, lava rock, or granite. Glass-ceramics can be transformed into predominantly ylassy or predominantly ceramic forms by the method of processing. Different forms will have different keach characteristics and other properties depending on the composition of the crystalline and surrounding vitrified (glass) phases in the waste form.

From a final waste form product performance standpoint, parameters affecting product performance, such as chemical stability, waste form leachability, thermal stability, mechanical durability, impact resistance to the generation of breathable fines, radiation damage resistance, and environmental compatibility have been identified $t o$ be characterized and optimized. Processing parameters such as slag/melt temperature and viscosity, electrical and thermal conductivities of the melt, waste solubility, melt corrosivity and volatility of high vapor pressure hatardous species must be considered to produce the desired waste form in an effective and eflicient manner.

The BSG silica-based glass waste form has heen approved for the immobilization of radionuclide-bearing high-level waste (HLW) and, as such, represents a standard of comparison in this study. A qualitative comparison of the performance of various glatsses and glass-ceramics is given in Table S-2. Phosphate glasses are durable, but have poor thermal stability and low solubility for many waste components and the glass melts are highly corrosive. Borosilicale glasses melt at lower lemperatures $\left(90(0)-12(k)^{\circ} \mathrm{C}\right)$ and as a result reduce volatilization of hazardous materials, and are less corrosive to the melter. BSG has good long-range chemical stability, thermal stability, mechanical stability, and, therefore, geod environmental compatibility. The silica based glass ceramics, ferroalumina silicates (iron-enriched hasalt or IEB), and the high-alumina silicate waste forms usually have 


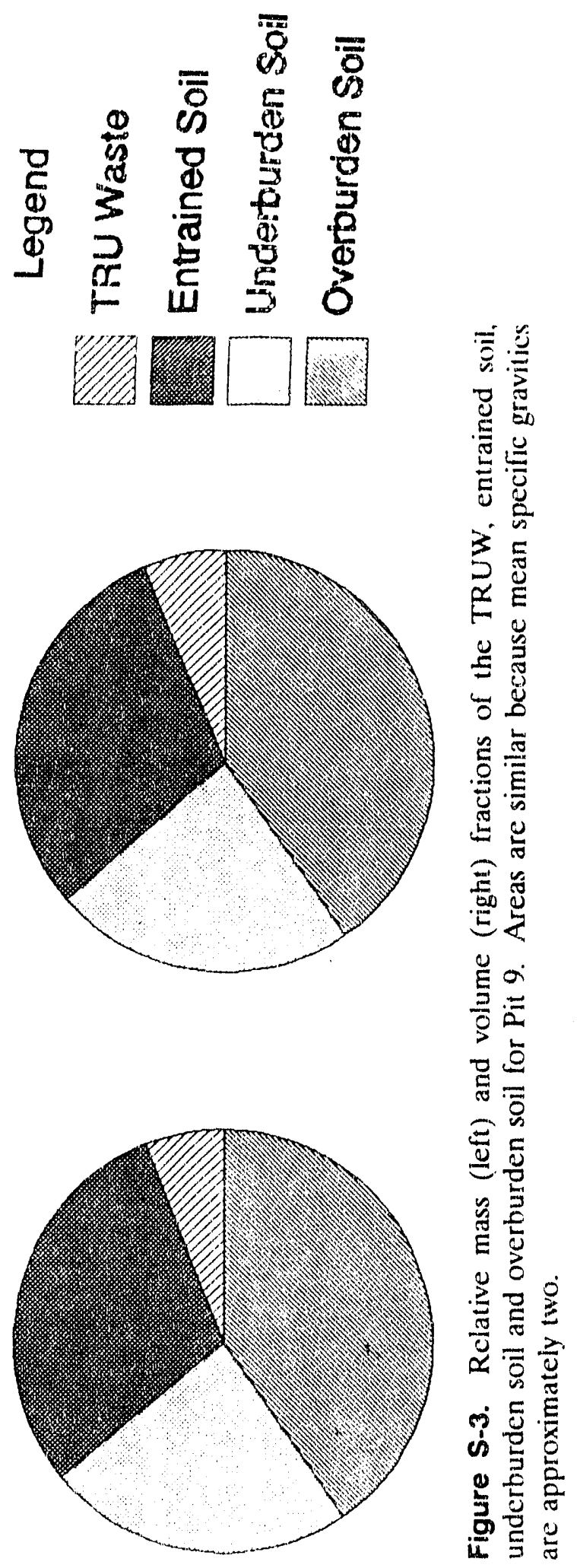



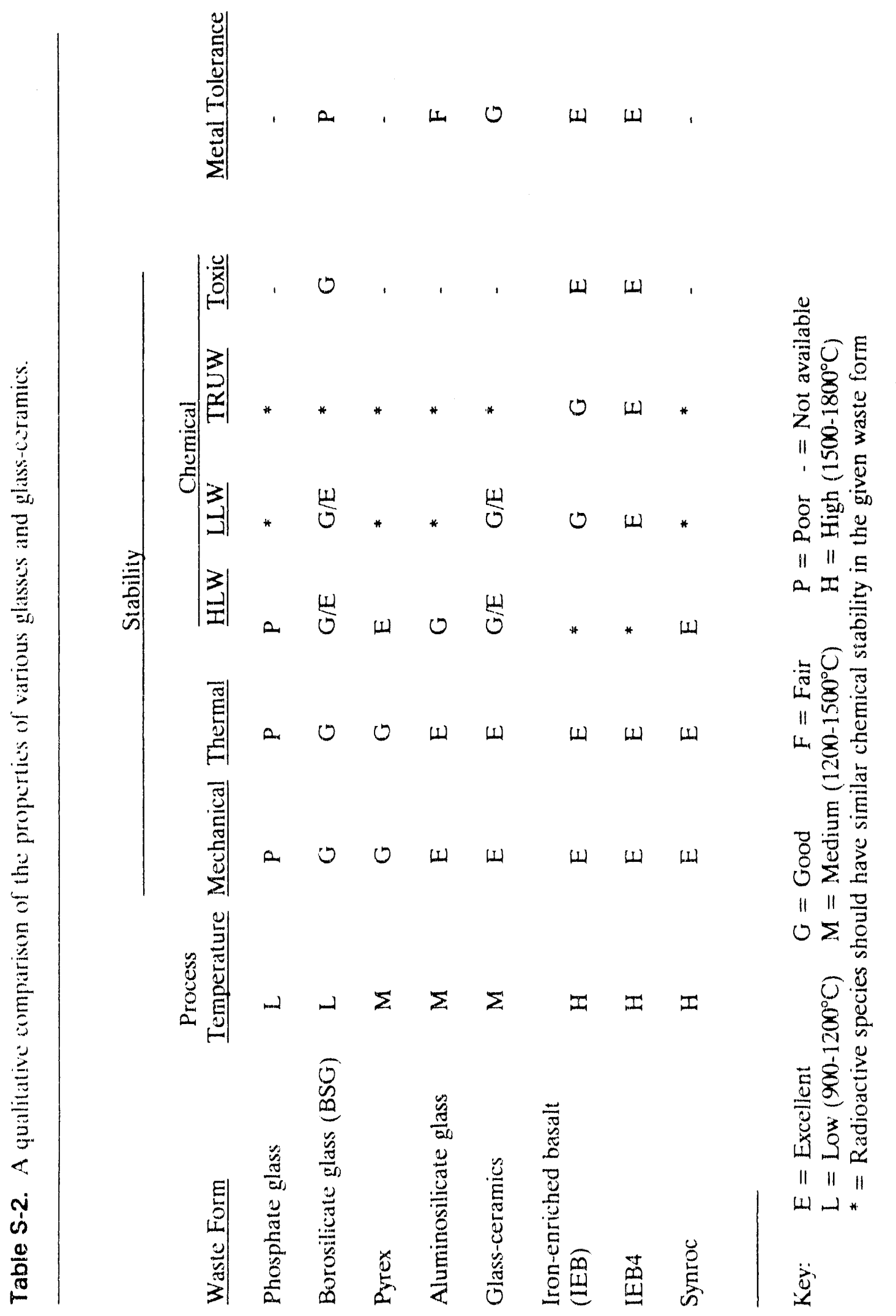
higher chemical stability, thermal stability, mechanical stability, and envirormental compatibility, than even BSG, in part due to their crystalline (rock-like) structure and higher temperature (energy) of formation. IEB is a high temperature silica-based, glass-ceramic with high concentrations of iron and aluminum oxide similar to naturally occurring basalt rock. Its composition variations were originally formulated based on various combinations of average TRUW and soil at the RWMC at the INEL. IEB4 is an IEB variation with small additions (1-10\%) of Group IV elemental oxides ( $\mathrm{Zr}$ and Ti) postulated to further increase the leach resistance of TRU and LL nuclides. Synroc is a titania based ceramic with a large concentration of $\mathrm{Zr}$ and $\mathrm{Ti}$ oxides and is made in a high pressure, lower temperature hot isostatic pressing process. High process pressures, low process throughput capability, and the additional host material stream (titania) required are present show stoppers for the Synroc process in this application, even if it may provide the best performanec of any glass/ecramic waste form considered. The metal tolerance in Table $S-2$ incicates the ability of the waste form to oxidize and dissolve a significant amount of the most prevalent metals, e.g., iron and aluminum. Again the higher temperature glass-ceramics have the ability to dissolve meize iron and aluminum oxides in the matrix.

The BSG waste form, approved for immobilization of radionucide-bearing, high-level wastes, has the advantage of lower processing temperatures; but the lower temperatures are incapable of melting iron (at $21538^{\circ} \mathrm{C}$ ) and metal oxidation rates would be very siow. BSG becomes extremely corrosive in this high temperature range. Further, the average TRUW material stream does not have a composition similar to BSG. Waste loadings would have to be small, perhaps $<10 \%$, to produce a BSG waste form. The result would be an increase in total waste volume of 5 to 10 times the original waste stream.

The buried TRUW has an average composition similar to the iron-alumina silicates, which when melted with or without added INEL soil yields the waste form material developed and known as iron-enriched basalt (IEB). IEB, as a final waste form, can accommodate higher waste loadings than BSG and has an associated increased process robustness for accommodating the expected range. of heterogencous input waste stream materials.

The IEB linal waste form possesses the following desirable characteristics as compared to BSO: (a) both fine grained and coarse grained IEB final waste forms have demonstrated a much better leach resistance than BSG, (b) IEB waste forms generally exhibit better mechanical and thermal stability than BSG, (c) the IEB fabrication process has high tolerance (acceptance) for all metals, including high melting temperature metals, (d) the IFB waste form and processing is very accommodating to the expected highly helerogeneous buried waste material and varying compositions, (c) IEB processes would produce higher volume reduction for the RWMC TRUW streams, and (i) properties of IEB final waste forms are comparable to the natural geological basaltic rock analogue.

Some limited existing IEB studies indicate that the addition of small amounts of $\mathrm{ZrO}_{2}$ enables crystals of $\mathrm{UO}_{2}-\mathrm{ZrO}_{2}$ to form in the $1 E \mathrm{~B}$ solid solution $\mathrm{to}$ form an even more leach-resistant material. This IEB variation material is herein given the name IEB4. Without $\mathrm{ZrO}_{2}$ present, uranium and plutonium precipitate as separate oxides in the residual glass phase allowing them to be more easily leached than if contained in the $\mathrm{ZrO}_{2}$ crystalline solid solution phase. It is expected that the TRUs will behave with $\mathrm{ZrO}$, in a manner similar 10 uranium; but this behavior remains to be demonstrated in tests. 


\section{System Processing Scenarios}

Processing system sectarios integrating various components and melters have been developed. The factors influencing processes within the melter are also discussed and R\&D requirements delineated. The processing scenarios pivot around the SDS Incinerator and Melting system. All the scenarios presented are believed capable of destroying hazardous organics and producing an appropriate final waste form to stabilize TRU elements and other hazardous noncombustible.

Sorting Options A, B, C, D, and E represent A) no separations and no incinerator, B) separation of combustibles, C) separation of nuncombustibles, combustibles, and metals, D) separation of bulk metals only, and E) no separations with an incinerator for the entire input waste stream. Soil disposition varies depending on the scenario. The sorting can be relatively limited (10$20 \%$ ) because of the robustness of the processing components. Special case (highly-radioactive and large objects) are assumed to have been sorted out for special processing prior to entering the thermal processing input waste stream.

Scenario I essentially represents the SDS seenario on Incineration and Melting with Postsort of the 'TRUW \& LLW. It utilizes the SDS Retrieval, Soils Processing, and Metals Decon Subsystems. Combustibles, noncombustibles, metals and soil are sorted for processing (Option C). The final waste orms are packaged, assayed, and temporarily stored pending ïnal disposal in a TRUW, Reclassified LLW, or LLW repository.

Scenarios II, III and IV are variations on Scenario I employing the various SDS subsystems in different configurations. Scenario $V$ assumes BSG as an objective and uses borosilicate glass frit and develops a BSG waste form instead of the natural IEB waste form where possible.

The presently recommended scenario from this study is II-E, as shown in Figure S-4. It is very similar to the example processing system discussed carlier and illustrated in Figure S-1. Scenario II-E is a no-sort option which includes both an incinerator and a melter. Seenario II-D is a close second choice and differs from Senario Il-E only in that bulk metals are sorted out for separate metals decon-treatment prior to incincration of the remaining waste streams. The metals separation is an added stage that may not be too complicated and may prove to be beneficial when more detailed design analyses are done. Third on the list is Seenario II-A with no sort and no incinerator, which uses the melter to do both the pyrolysis/oxidation of combustibles and the melt/vitrification of all noncombustibles. Advantages are the no sorting and fewer components, countered by a potentially much more complex process monitoring and control system.

Scenario II, Option E, is the highest priority because it requires a minimum of sorting (no sort other than Special Case), the simplest control of incinerator and melter, only one melter, and maximum safety and maintenance. It requires a less complicated retrieval system (to be determined by others) than the SDS Retrieval Subsystem, one that sorts out overburden soil which may be clean and passes the waste stream and entrained soil to the sizing unit ( $<50 \mathrm{~mm}$ or $2 \mathrm{in}$.) with an intermediate assay for safety. The contaminated underburden soil is routed to either the soils processing system (to be determined by others) or the melter, if needed. After sizing, the waste stream is routed to a thermal desorber with the pyrolized gases going to the incinerator for additional pyrolysis and partial combustion. The solids go to a high-temperature, oxidizing-slag, arc/plasmaheated melter. The metals may be surface oxidized, melted, and tapped from the bottom of the 
침
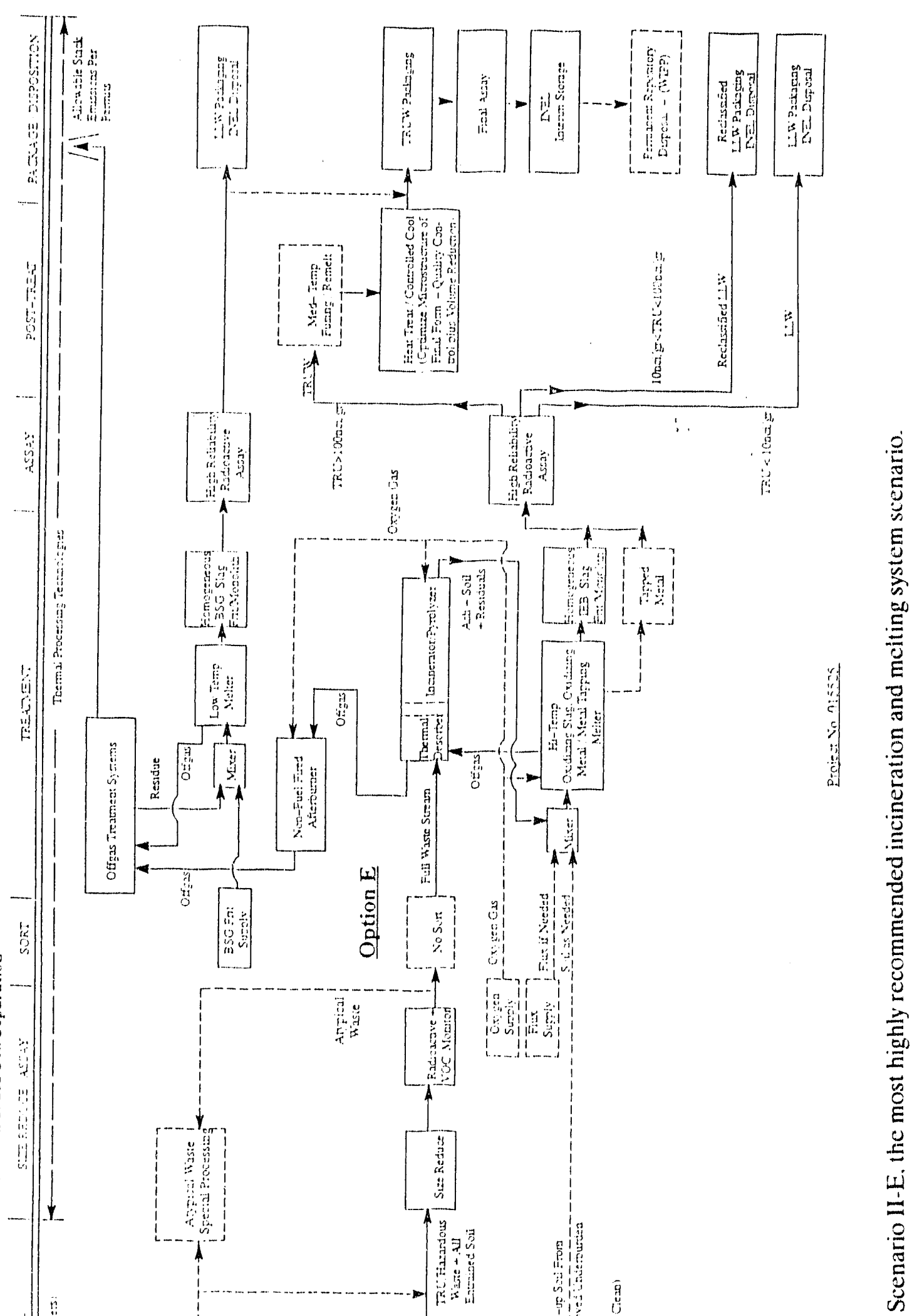

|

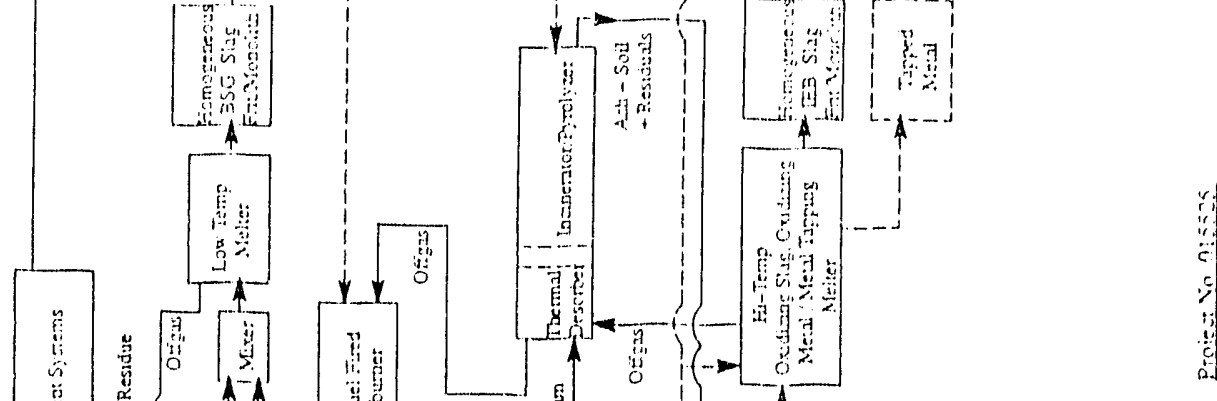

|| $\mid \begin{aligned} & 0 \\ & 0 \\ & 0 \\ & 0 \\ & 0 \\ & 0 \\ & 0 \\ & 0\end{aligned}$
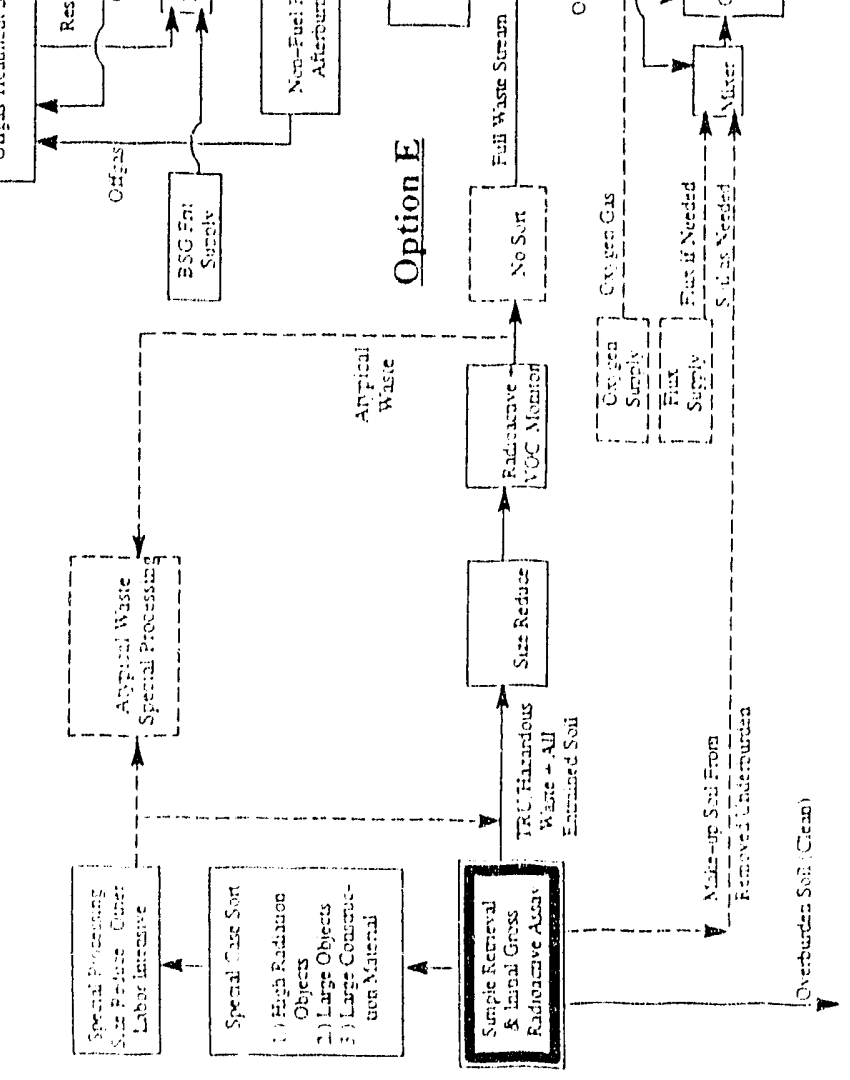

xxvi 
melter or totally oxidized and dissolved into the slag as found to be necessary in testing. Any combustibles leaving the incinerator will be routed to the incinerator and offgas treatment system. as appropriate.

If separate TRUW disposal is selected, the output slag normally cast as a monolith could be fritted to a size potentially more amenable to an assay (to alow separating TRUW, Reclassified LI.W. and LLW, if needed). It has been shown that a water quench may become contaminated under these conditions, requiring secondary treatment. The TRUW frit would be remelted or fused, heal-treated to obtain the optimum final waste form, and poured into appropriate packaging. It is preferable to pour the slag into a monolith in the linal packaging and use controlled cooling to obtain the optimum tinal waste form, if an aceeptable assay can be performed.

The melter processes need to bo tested to confirm current expectations and o determine how to minimize HVPM carryoser, including TRU and LL sudionuclides. Oxidation of the metals followed by slow diffusion of the HVPM through a thick slag or foaming layer is expected to reduce the loss into the offgas significanlly. Any volatilized toxic or radioactive materials will be collected in the offgas treatment, assayed, dissolved in BSG in a low-temperature Joule-heated melter, and packaged for disposal. Collection may be by condensation/solidification or other specific process (e.g., for $\mathrm{Hg}$. These are wo betermined for specific materials later.

It should be noted that Scenario II A cmploys a pyrolyzing-gas, high-temperature, oxidizingslag. plasma are-heated melter that replaces the incinerator and the nonpyrolyzing melter of Scenarios II.D and $\mathrm{E}$. This scenario has been partially demonstrated in early test series at the INELMSEButte Component Development Integration Facility (CDIF), where RWMC soil and simulated metal, combustible, and TRU waste have heen processed in an oxidizing high-lemperature, plasma-heated melter. The combustithe organios were axidized in the primary chamber with negligible or no sooting. Although an alterburner is required to ensure meeting destruction removal efficiencies required by EPA for hazardous organies and PICS. The metals at a $3 / 1$ metals-to-soil mass ratio were completely oxidized. The slag ciast into drums went through a $1-2$ day cooling period with a resulting microstructure that was predominanty enstalline (ceramic rock-like) material, with very little vitrified (ghassy) material. Prior experiments with INEL soil and some diesel fuel resuled in a predominantly glassy material. The waste form compositions from this plasma-healed melter (PHM) are essentially dupicates of what was lound a decade ago in the INEL. IEB research, using a high-temperature Jouk-heated meler (JHM).

\section{Melter Processes}

There are several primary within-melter process issues that influence the product of the process and the capabibity of the melter. As presensly identified, these are 1) melt fluidity viscosity, 2) electricial conduclivity. 3) materials corrosion erosion, 4) slag chemistry and TRU retention. 5) slag chemistry and HVP.H metals retention. and 6) controlled cooling for devitrification.

\section{Fluidity}

The compesition and temperature of the melt determine its viscosity. and thermal and electrical conductivity-hence. the fluidity and uniformity of the melt. Increasing the silisa or alumina content increases the viscosity and decreases the fluidity. Adding fluxes, such as alkali ( $\mathrm{Na}, \mathrm{K}$. cte.) or alkali carth ( $\mathrm{Ca}, \mathrm{Mg}$. ele.) compounds decrease the viscosity. Alkalis are dissolved into the glassy phases and not the crystalline. from which they have a susceptibihty to readily leach and aflect the 
leachability of other dissolved substances. As a result, alkali content in the siag should be minimal. The addition of zirconia or zircon to the IEB melt to form a solid solution with U-238 and TRU will raise the temperature required to maintain fluidity. Figure S-5 illustrates the effect of adding flux to the slag melt.

\section{Electrical Conductivity}

Joule-heated melters require the electrical conductivity of the melt to be in a acceptable narrow range in order to obtain the optimum heating. If it is to low, the current will be to low, and the $I^{2} \mathrm{R}$ heating too low. If too high, the bath will be short circuited and will not heat as broad a volume. Melted metal collected at the bottom of the bath can short out the electrodes. Because of this constraint on electrical conductivity (and viscosity), Joule-heated melters are limited to a relatively narrow range of composition changes around the design point. This limitation is not amenable to the wide variations in RWMC waste streams expected. An extensive sorting, sampling, and control system would have to be developed to enable Joule-heated nielters to be vitized for processing the SDARWMC TRUW streams.

In arc/plasma-heated melters, the viscosity is controlled by temperature and the electrical conductivity is not a major factor. Transferred are and plasma torch-heated melters do have a Jouleheating component; but arc/plasma radiation, strong arc-generated convection, and conduction heating at the electrode attachment region are usually the dominant heating mechanisms. The main disadvantage of the arc/plasma-heated melters for waste processing is ihe potential for increased vaporization of HVPM at the higher processing temperatures utilized.

\section{Corrosion}

Corrosion can occur at the refiactory wall near the slag surface, usually due to convective currents in the slag and oxidation or other chemical reactions among the gas, slag, and refractory materials. These problems are accelerated at higher temperatures. With the intense energy disposition possible with plasma/are heating, the melter walls can be water cooled and a sk: il of the slag material built up to protect/replace the refractory. These problems are melter configuration and materials dependent.

Corrosion of the electrodes can be a problem in both JHM and PHM. Water-cooled copper clectrodes in high-powered plasma torches typically operate for $300 \mathrm{~h}$. Consumable graphite electrodes in arc-heated melters can be oxidized unless operated in a reducing mode or coated to reduce surface oxidation. Oxidizing-slag, pyrolyzing-gas phase melters experience less corrosion than totally oxidizing reactors. A small JHM with nitrogen cooled walls operated for over $2200 \mathrm{~h} \mathrm{in}$ producing IEB at the INEL on molybdenum electrodes. Each melter configuration has its advantages and disadvantages which must he understood for proper design and testing in new applications.

Table S-3 presents a matrix of waste forms versus melter types. The waste form composition dictates an approximate operating temperature range, which along with the type of electrodes used, determines allowable redox states to minimize cortosion. The type of refractory or use of a watercolced skull is also based on the composition and temperature range. Tabie $5-.3$ also indicates the types of waste streams treatable for the cemperature ranges given. 


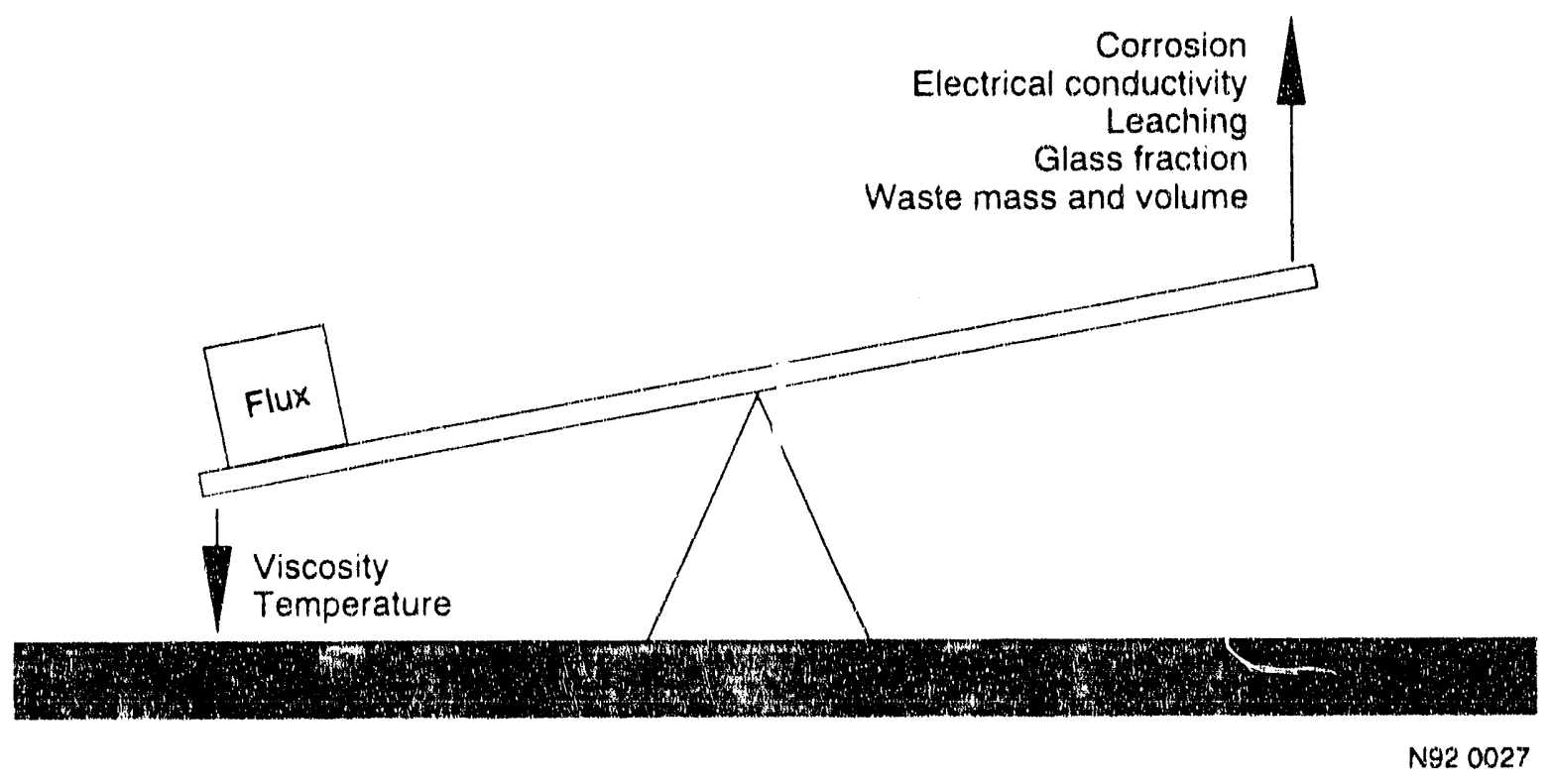

Figure S-5. Illustration of the effect of adding flux to the slag melt. 


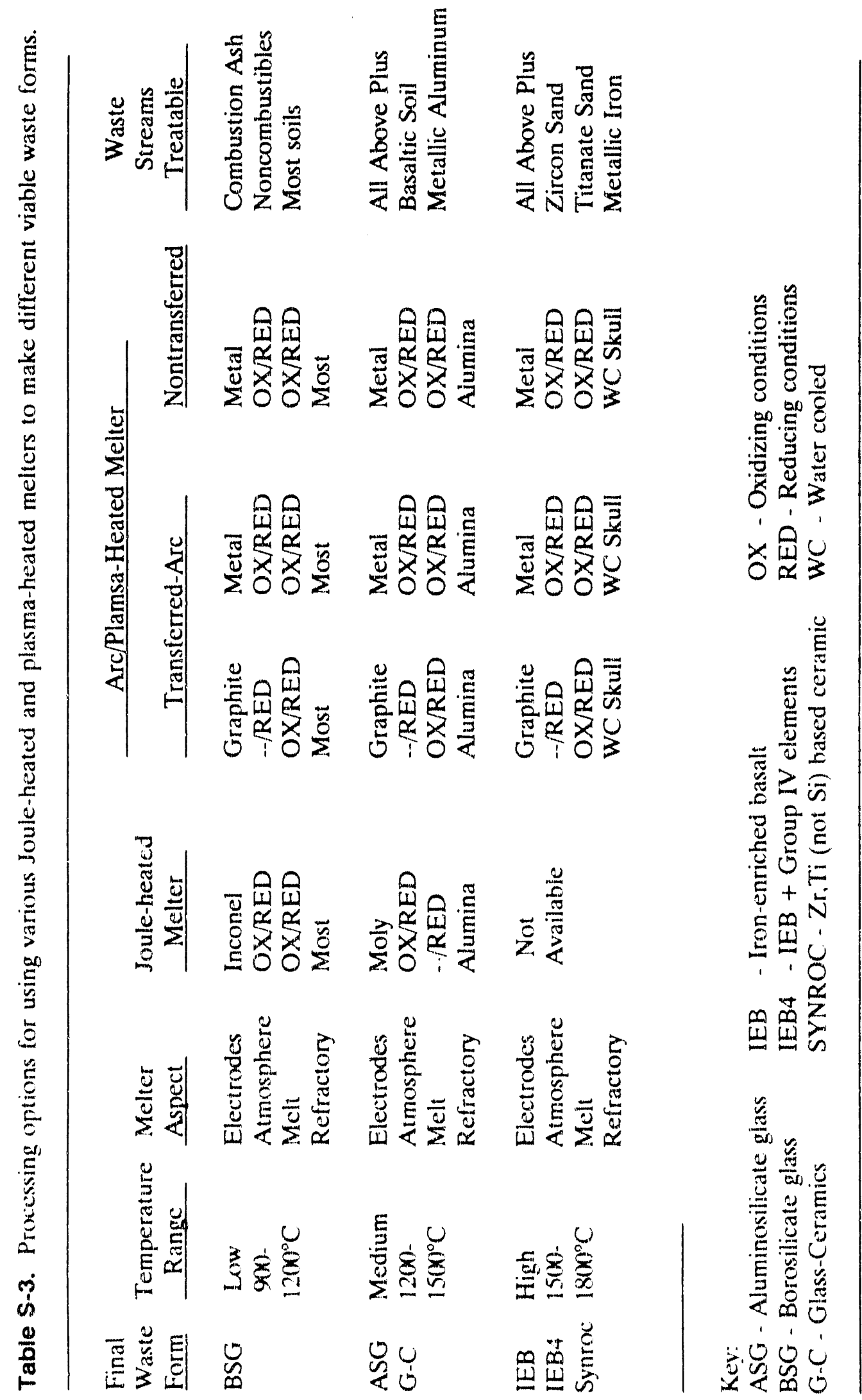




\section{Slag Chemistry and Retention of TRU Nuclides}

The slag melt must be able to dissolve the TRUs and incorporate them in its matrix. The TRU metals are extremely reactive and form insoluble oxide compounds in the glass matrix or oxide solid solutions with alumina, titania, and zirconia in crystalline phases. Tailoring the slag chemistry so that ceramic phases are achieved to retain the TRU species in solid solution is highly desirable.

\section{Slag Chemistry and Control of HVPM}

The slag chemistry process (materials, compositions, temperature, pressure, time, mixing) is the most important part of the melter operation because it deals directly with the fabrication of the final waste form material and its performance characteristics. There are several important parameters to be considered in the fabrication of an acceptable high-integrity final waste form, one is the retention of the HVPM. The slag must be able to retain an aceptable fraction of the high vapor pressure metals within its matrix. The volatilization of the HVPM during processing is closely related to the redox state and the temperature of the melt. It is desirable that the volatilization of the HVPM be minimized even at high temperatures. Tailoring the slag chemistry to produce high temperature ceramic phases which will retain these species, such as $\mathrm{Pb}, \mathrm{Zn}, \mathrm{Cd}$, etc., in stable compounds or solid solutions is highly desirable. Detailed tailored-design studies of the slag chemistry are needed to enable optimization of the retention of HVPM in the slag. The offgas system must be designed to trap any transported HVPMs.

\section{Vitrification/Devitrification Processes}

Controlled cooling would allow a manipulation of the vitrification and devitrification processes in the slag to produce the desirable durable ceramic phases with an engineered grain size. These controlled cooling, rocesses have been shown in INEL IEB research to produce a final waste lorm with much superior product performance characteristics. Typical cooling procedure is to cool the slang to the recrystallization or nuckeation temperature (perhaps $950^{\circ} \mathrm{C}$ ) for a period of one to two hours, then raise the temperature about $100^{\circ} \mathrm{C}$ for 4.8 hours to increase the crystal growth rate, followed by a rapid quench to retain the nonequilibrium state microstructure at ambient temperature. The procedure and recrystallization temperature are dependent on composition and Redox state in the slag. Appropriate testing needs to be done to determine optimum procedures for typical waste slag compositions.

\section{Some Initial Melter Test Series Results}

In selecting a conceptual melter design, the most fundamental question is: Can it melt the expected mix (range) of INEL buried waste and contaminated soil? Several recent limited test series have yiclded information relevant to this fundamental melter question for INEL wastes.

No recent test results from JHM applications for typical INEL wastes/soils are available. An initial series atlempt was begun; however, JHM manufacturers indicated that quite a bit of flux would be needed to melt the soil and they could not handle much metal. High temperature JHM would require development. This was consistent with past work at the INEL with a lab-scale, high temperature JHM that indicated temperatures of $1300-150()^{\circ} \mathrm{C}$ can be reached to melt INEL soil/waste in a JHM, but with severe consequences to electrodes and refractory (reliability issues). JHM for lower temperature ranges are available, are relatively simple to design and use, and give good low temperature $\left(1050^{\circ} \mathrm{C}\right)$ glass waste forms. 
INEL soil with metals has been vitrified in tests in a pot melter at the Plasma Energy Corporation (PEC) with a nontransferred plasma arc/torch. Also, slag from the ACT (soil plus diesel fuel) and RWMC (soil, metal, diesel fuel, and wood chips) test series at INEL/MSE CDIF at Bulte, MT, was generated in the Retech plasma centrifugal reactor with a transferred plasma are torch. The PEC test slags were rapidly cooled $(1-2 \mathrm{~h})$ and found to be mostly glass phase with some small crystab. Leach tests for toxic metals were well within toxicity characterization leaching procedure (TCL.') requirements. The ACT test series was cooled slowly (1-2 d), and had a much larger fraction in erystalline or ceramic phase. The RWMC slag samples were also cooled slowly (1-2 d) and were almost all crystalline phase. All the metal and the organics had been oxidized. The RWMC series tests used wide variations in input feed composition, demonstrating the robustness of the basic process. The minerals and structure of the PHM-generated slag were very similar to the high temperature JHM slag generated on the INEL IEB research a decade ago. The results of these tests are very encouraging in that PHM clearly can be used to make a good waste form from the typical RWMC waste and rock mixture and that the knowledge gained from prior research on IEB formed using a JHM is applicable to PHM-generated IEB. Either type of melter can be used as appropriate to generate the required waste form. It appears relatively easy to get excellent waste forms from high temperature plasma-heated melters, but the extent of HVPM loss from the melt needs to be further investigated in any higher temperature melter. Additional melter evaluation tests are clearly needed.

\section{Conclusions and Recornmendations}

The average TRUW waste stream at RWMC has the composition of an iron-enriched basalt, without adding soil. Adding soil still gives a waste form that is an IEB. Altempting to use: or generate waste form compositions other than IEB, such as BSG, would result in low waste load. and not take advantage of the natural features of the TRUW in RWMC. There are no existing commercial melter systems on the shelf that can be used today to demonstrate application to RWMC wastes and generate IEB. There are, however, high temperature plasma- and are-heated melters well demonstrated for metal ores processing that are expected to be demonstratable for INEL buried waste applications. There are lower temperature JHMs demonstrated for use on glass and HLW. These would require high temperature development work. If the melting of structural metals is required, a high temperature PHM will be required. Melting of INEL mixed wastes and soils, even without metals, will require a medium to high temperature range, $1350-150()^{\circ} \mathrm{C}$, more easily achieved with a plasma/arc-heated melter than a JHM. Ash from the incinerator and residue from the offgas treatment system could probably be treated in a low temperature JHM, possibly using BSG frit. The final waste form can be put into an optimum IEB glass-ceramic form via a controlled cooling process. An integrated system design concept presently recommended is shown as Scenario II-E, with no sorting, a thermal desorption/incineration step for combustibles with an afterburner to ensure complete combustion, melting of the noncombustible portions of the waste soils input with surface oxidation of metals, and free reduced metals tapping. Any high vapor pressure metals carried over in the offgas will be condensed and filtered for separate treatment, perhaps in a low temperature melte: step.

The following R\&D topics need to be addressed in the near future for completion of development and pilot-scale demonstration tests on a reasonable schedule: (a) erucible lests of the transport and disposition of HVPM (including Cs-137) and metal oxides in high-temperature (150). $18(0)^{\circ} \mathrm{C}$ ) processing, (b) crucible and melter tests of the retention and dissolution of TRUW and reconfirmation of uranium in circonia-augmented over the range of incoming waste compositions and stags, including the effect of the redox state in the slag and its influence on the HVPM, as well as 
controlled cooling processes and their influence on the phase composition of the final waste frirm, (c) crucible and melter tests to study metal oxidation and dissolution in the melter in both surface and total oxidation modes, (d) crucible and melter tests to confirm refractory/skull corrosion and protection effects, and (e) melter tests to confirm and resolve expected electrode corrosion/erosion effects. Further design studies, safety related studies, and establishment of a verified set of melter design evaluation tools (models) are needed. 


\section{Thermal Processing System Concepts and Considerations for RWMC Buried Waste}

\section{INTRODUCTION}

\subsection{Background}

This report presents the determination of a preliminary conceptual process systems design, and related processing conditions considerations, for thermal lechnologies based treatment of Idaho National Engineering Laboratory (INEL) Radioactive Waste Management Complex (RWMC) buried wastes. Early conceptual definition of remediation processes is necessary to allow for the focused and iterative evaluation and development/demonstration of the treatment processes and the enabling process technologies (process equipment).

From the early 1950) through 1972, low-level waste (LLW) generated at the INEL and lowlevel alpha emitting wastes (defined as transuranic wastes or TRU) were buried in pits and trenches at the Subsurface Disposal Area (SDA) of the RWMC. In 1972 this practice was stopped and the Department of Energy (DOE) began segregation of the wastes, placing TRU wastes in retrievable surface storage at the Transuranic Storage Area (TSA) of the RWMC. Most of the transuranic wastes were generated in the production processes for nuclear weapons at the Rocky Flats plant. Because of the nature of these processes, the TRU wastes contain listed and characteristic hazardous materials as well as radionuclides and are, therefore, catcgorized as mixed (radiological and hazardous) wastes.

In 1989 the INEL was placed on the Environmental Protection Agency's (EPA's) National Priority List, which requires remediation of the SDA using the Comprehensive Environmental Response Compensation, and Liability Act (CERCLA) decision process. Using the CERCLA process, a remedial action option can either be "no action," in situ treatment and disposal, or ex situ treatment and disposal. A "Preliminary Systems Design Study" (SDS) ${ }^{1}$ was conducted in 199()/91 to provide a top-level conceptual remediation systems basis for identifying and focusing waste technology development/demonstration efforts in line with INEL Environmental Restoration buried waste remediation problem needs. The SDS considered four treatment categories related to the final waste form performance: treatment in place, processing to a waste form acceptable for disposal at the DOE's Waste Isolation Pilot Plant (WIPP), processing to a waste form that satisfies EPA's critcria liof land disposal restrictions (L.DR), and processing to a leach-resistant, high-integrity, vitreous/erystalline (glass/eramic) waske form (that satisfies all requirements). Of 73 treatment system alternatives identilied and sereened, 12 coneepts were selected and then evaluated based on the stage of technology development, the need for luture rescarch and waste-specific demonstration, programmatic and technical risks, schedule requirements, and costs. Life-cycle cost comparisons indicated that the in situ treatments cest the least (no retrieval cost), but thest: are not within the scope of the present study. Among the ex situ treatments, the costs were similar for all processes. The ex situ Incineration and Melting with (low-level waste) LLWW Postsort process system option was identified as producing a waste lorm which will meet all the WIPP, LDR, and leach/integrity conditions and received the highest overall system concepts ranking flied with in situ vitrification (ISV) and Retrievall: hence, this system was chosen as a starting point for the present more detailed work on incineration and melting treatment processes and technologics. 
The thermal processing systems and technologies considered herein are focused on, but not limited to, the incineration and melting system process lechnologies and options recommended by the SDS. Processes associated with Joule-heated melters (JHM) and are/plasma-heated melters (PHM) have heen considered. Processes affecting the melting or dissolution of the mixed waste streams (pretreatment), the microstructure and durability characteristics of the final waste form (posttreatment), and offgas treatment, in addition to the internal melter processes, have been considered.

\subsection{Overview}

Design and development of a waste treatment process requires the identification and consideration of incoming materials (waste streams) characteristics, output product requirements/criteria (final waste form and performance), and the iterative match of capability of enabling process technology/equipment to the desired process conditions. The purpose of the work reported herein is to provide the next level of thermal processing systems investigation and conceptual design beyond the SDS.

In particular this study was intended to provide a basis for evaluation of the key technology components, particularly the melter, within a thermal processing system context, and to lead to defining preliminary functional and operational requirements for the conceptual design of system components. This study has, therefore, included several separate but related parts.

The study has examined the available buried waste description data in an attempt to better deline the incoming waste streams for thermal process conceptual design. This is reported in Section 2 and includes definition of material types, amounts, potential processing problems, whether sorting is needed/desirable, and how these factors inlluence melter design and processing. Two preliminary design bases waste stream classifications are proposed, representing the range of extremes (an "As Found" mixed waste stream classification and an "As Separated" waste siream classification) to consider for processing.

The study has examined the final product of the thermal process, that is the linal waste form product options and performance eriteria within the context of the requirements for producing a highly-leach resistant durable glass/eramic that will meet the DOE requirements for WIPP, the Department of Transportation (DOT) nuclear waste transportation requirements, the EPA LDR requirements, and have capability for meeting future more stringent requirements. Section 3 reports these final waste form considerations. Variation in composition and volume of the final waste form hased on different waste streams is considered. These compositions are compared to known glass, glass-ceramic, and ceramic compositions to determine the melting process operating conditions and probable slag and final waste form properties. Appropriate materials characterization tests for the waste form are suggested 6 verify that the characteristics meet stated objectives for physical and chemical performance.

Considering the waste streams and desired final waste form, Section 4 identifies and compares several potential thermal processing system scenarios/conligurations utilizing available melter technologies beginning with and pivoting about the bascline SDS case. Factors intluencing processes within the melter are atso discussed and key development/demonstration requirements identified. Processing considerations include both the preliminary system design ol components and processes within the melter. Incincration will use conventional lechniques and components. Various scenarios for the system design using conventional components are presented, as well as a recommended 
scenario. The types of melters which should work under the particular processing conditions are delineated. Smelters and melters of similar materials are in conmon practice but none have completed process applications demonstrations/development for the particular waste streams being considered here. Critical processes within the melter are discussed and aspects of processes requiring research and development (R\&D) to ensure successful processing are identified. The effect of nonhomogeneous feed composition is eonsidered. The processing results are integrated with results from the reports focusing on other aspects of the TPT project, including: a survey of prior research at INEL on the iron-enriched basalt waste form, ${ }^{2}$ the assessment of present melter JHM and AHM/PHM capabilities, ${ }^{3}$ and the survey of modeling melter gas and slag phases for understanding and control purposes. , $^{\mathrm{b}}$ Finaly, melter and crucible tests are proposed and prioritized in order to resolve key questions related so optimizing operation of the melting system processes.

In Section 5 several recent test series results related to the melter thermal processing systems issues are briefly discussed.

Section 6 then provides a final summary of conclusions and recommendations.

a. S. Paik, "Melter Models for the Thermal Processing ol Mixed Wastes," WTD-92-33, January 1992.

h. R. L. Williamson, "Slag/Melt Modeling Capabilitics at INEL," Letter report, January 1992. 


\section{CLASSIFICATION OF INPUT WASTE STREAMS}

The classification of input buried waste streams is important to determine the material caliegories, how the materials need to be processed, where the potential processing problems exist, and the quantities of materials expected. Two general classifications will be considered. The first will be the average no-sort or "As-Found" in the ground case, as obtained from recent reports on the contents of the SDA. The second will be an "As-Separated" case, which separates combustibles, noncombustibles, metals, and soil, as in both the presort and postsort of LLW from TRUW as recommended in the SDS Report (see Relerence 1). The two cases are considered, then comparisons made, and considerations for appropriate waste streams to be input to the incineration and melter processing scenarios are recommended.

\subsection{As-Found Classification}

\subsubsection{Basis for the As-Found C'lassification}

The classification of input waste streams is based on information from existing summaries of waste description data for the SDA at RWMC. The main references used were Vigil and Arrenholz and Knight, ${ }^{\text {cd }}$ which also referred to prior studies. Of major interest are Trenches 1-10 and Pits 1-6, 9, and 10 because they contain TRUW. Many of the other trenches and pits contain only LLW, and are not the focus of this project. The history and contents of these trenches are described in more detail in the above refierences. Figure 2-1 presents an overview of the major activities at RWMC related to this work. Trenches 1-10 were filled with INEL MFP/LLW, RFP TRUW, and various off-site wastes from July 1952 until November 1957. The wastes were not segregated by type. At this time the Rocky Flats Plant (RFP) waste was increasing and it was decided to use pits. In the pits, the INEL/LLW and the RFP/TRUW were segregated, but were often located in the same pit. Prior to 1963, the waste had been stacked in the trenches and pits. Between 1963 and 1969 the waste was dumped in the pits in order (o) save cost and limit worker exposure. Since 1970, the RFP TRUW has been stored in the TSA. The contents in drums from Pits 11 and 12 were refocated to the TSA circa 1978. The TRUW in the SDA was rated at greater than $10 \mathrm{nCi} / \mathrm{g}$; whereas, in the TSA the rating was greater than $100 \mathrm{nCi} / \mathrm{g}$.

The specific data used as background for this report is included in Appendix A for reference. Additional detailed information on the contents and the location within the trenches and pits that will be useful during actual remediation is being generated by Waste Technology Development Department (WTDD) personnel.

c. D. A. Arrenholz and J. L. Knight, "A Briel Analysis and Description of Transuranic Waste Disposal in the Subsurface Area of the Radioactive Waste Management Complex at the INEL," WTD-9()-(0)16, November 199).

d. D. A. Arrenholz and J. L. Knight, "Historical Report of Transuranic Waste Pits and Trenches at the Subsurface Disposal Area of the Redioactive Waste Management Complex at the INEL," WTD91-()27. August 1991. 


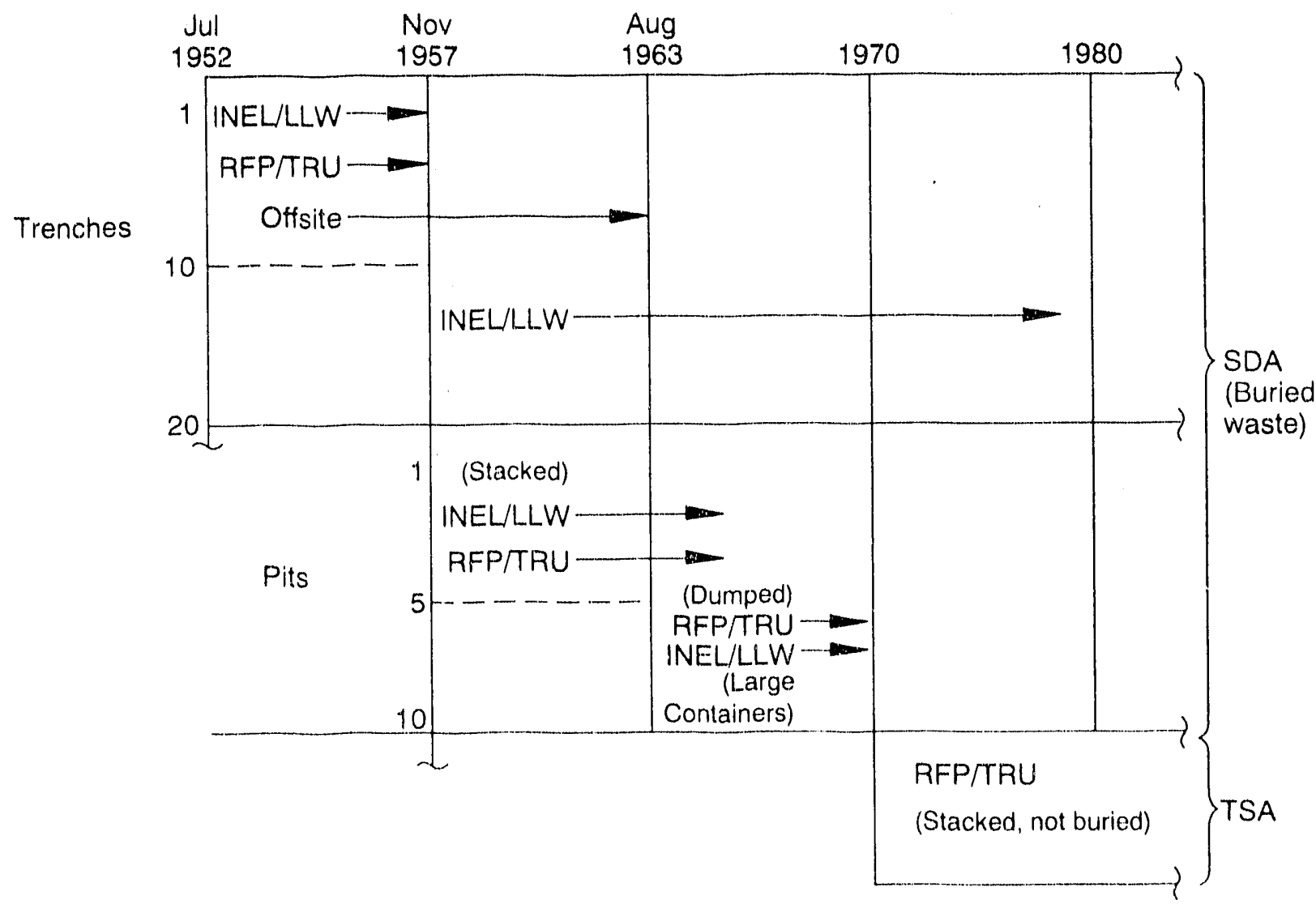

N92 0079

Figure 2-1. A schematic overview of the major storage activities at RWMC related to this work. 


\subsubsection{Initial As-Found Classification}

The classification of waste streams generated in this report is based predominantly on Tables A-9 and A-11. The classification is for the purpose of defining the type and approximate amount to be processed in order to determine the necessary processes. It is not the purpose of this work to determine quantitative flow process conditions. Table $2-1$ provides a classification of the materials in the selected trenches and pits as determined here from the prior tables. The data for the trenches is incomplete at this time. It can be seen that in the various pits there is a wide variety of classes of materials, but the pits are relatively consistent in "composition" (neglecting amounts), with a few exceptions in certain pits. As an example, all the pits have TRUW (Pu and Am), LLW (U, Co-60, Cs-137, Sr-90, etc.), inorganic sludge (hydrated metal oxides), steel and other metals with low reactivity, construction materials, cemented organics, and miscellaneous containerized organics.

Contents of some of the pits maly not be sufficiently well known to be identilied in the sourees used, so only items that are known $t(1)$ be absent should be dismissed. An example is the lack of nitrate inorganic sludges in Pits 1.3 and 5 because they were not received from RFP until 1967, by which time Pits 1.3 and 5 had been closed. Pits containing metals (Na, NaK. Pb, Zn, Hg, Li, ctc.) with special processing requirements appear to be Pits 2, 3, and 9, but Pits 4, 5, 6, an 10 also contain similar metals, but in as yet undetermined extent. Much of the $\mathrm{Li}$ and $\mathrm{Hg}$ is in batteries and may very well be sorted out. NaK is a liquid-metal coolant, but is a solid at room temperature.

Other special or unique processing may need to be applied to handle chloride, fluoride, and radium salts (Pit 2), hydrochloric and hydrolluoric acids (Pits 2 and 9), sodium hydroxide (Pit 9), animal carcasses (Pits 2 and 3), Butyl stcarate (Pit 3), and some phenyls (Pits 1, 6, and 10). Most of the other material types are in a sufficient number of pits (and probably (renches) that they should be handied by the mainline process.

\subsubsection{Proposed As-Found Classification}

A review of Table 2-1 indicates that most of the trenches and pits have similar types of materials as a result of the nature of the sources: RFP/TRUW and INEL/LLW. For similar reasons, the composition of the waste materials depending on the ratio of 'TRUW to LLW is similar with notable exceptions, i.e., the INEL SL.-1 waste, the RFP Recovery Facility fire, etc.

The proposed As-Found classification for input waste streams is based on Pit 9 because more explicit information about contained materials is presently available (from the above references) than for any of the other pits or trenches. Pit 9 does not apparently contain the halogen salts of Pit 2 , the animal remains of Pits 2 and 3 , butyl stearate of Pit 3, or the phenyls of Pits 2, 6, and 10. The various materials have been put into 18 categories in Table 2-2. The table also lists volumes and masses based on data from Table A.11 lor Pit 9 . Volumes and masses were converted using density data from Table A-10 and other sourees. ${ }^{5}$ Though speculative because volume eoneentrations are not known precisely, approximate densities are necessary to get an estimate for the processing. Figure 2-2 illustrates the relative mass fractions of $\mathrm{Pil} 9$ in a pie chart. There is considerable uncertainty surrounding the values shown in Table 2-2, and this must be recognized when considering melier processing. 
Table 2-1. Preliminary tabulation of materials found in buried waste in selected trenches and pits (see footnoted).

Metals

$\mathrm{Na}, \mathrm{NaK}, \mathrm{Mg}$,

$\mathrm{Pb}, \mathrm{Zn}$

$\mathrm{Hg}, \mathrm{Li}$

Other

TRU (a-cmitters)

$\mathrm{Pu}, \mathrm{Am}$

LLW $(\beta / \gamma$-emitters $)$

$U-235.238$

MA.P. Co-60, etc.

MFP, Cs-137, etc.

Tritium. Th, $\mathrm{Cf}, .$.

Inorganic Sludges

741.2 Hydrous oxides

( + Li. $\mathrm{Hg}$ batteries?)

Trenches

$\overline{12345678910}$

\begin{tabular}{lll}
\multicolumn{3}{c}{ Pits } \\
\hline 1234 & 569 & 10 \\
& $\times \times x \quad$ & $x$ \\
$x$ & $x$ \\
$\times x$ & $x$ \\
$x$ & $x$ \\
$x \times$ & $x$
\end{tabular}

$745 \mathrm{Na} / \mathrm{K}$ Nitrates

74R Cemented Nitrates

Inorganics

$x \times \times \times \times \times \times \times \times x \quad x \times \times \times \times \times \times x$

$\times \times \times \times \times \times \times \times \times x$

$x \times x \times x \quad x$

$x \times \quad x$

$x \times x \quad x \times$

$\mathrm{x} \times \mathrm{x}$

$x \times x \times \times \times \times \times \times \times \quad x \times x \times x \times x \times$

$\mathrm{x} \times \mathrm{x} \times$

$x \times \times \times x$

Machinery, SL-1/Fire waste

Construction, Fire Matls

746 Empty oil drums in cartons

$\mathrm{NaOH}$

Acids ( $\mathrm{HCl}, \mathrm{HF}$ )

Asbestos

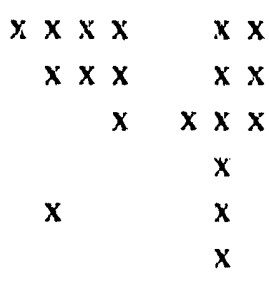

$x$

$\mathrm{x}$

$x \times \times \times x$

$\mathrm{x} \times \mathrm{x} \times$

743 Alcohols. Acids. Versenes

Organics-Miscellaneous

Oils. Freons. Ethy. Glycol.

Animal carcasses

Butyl Stearate. Meth. $4(x)$

Misc. solvents

Teraphenyls, diphenyls...

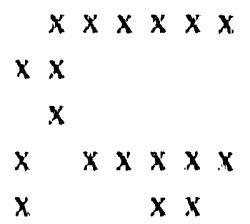

a. Some of these may to cemented (in with the 743 waste). 
Table 2-2. Proposed As-Found classification of input waste streams. Mass/Volume data is from Pit 9 with estimated conversions from Table A-10.

\begin{tabular}{|c|c|c|c|}
\hline \multirow[b]{2}{*}{ Material Category (Pit 9) } & \multirow{2}{*}{$\begin{array}{l}\text { Specified } \\
\text { Mass or } \\
\text { Volume } \\
\end{array}$} & \multicolumn{2}{|c|}{ Calculated Estimate } \\
\hline & & Mass (kg) & Volume $\left(\mathrm{m}^{3}\right)$ \\
\hline 1. Na, NaK, Mg (Na Comp.) & $3.469 \mathrm{~kg}$ & 3.469 & 1.9 \\
\hline 2. $\mathrm{Pb}, \mathrm{Zn}(\mathrm{Pb}$ in $\mathrm{Pit} 9)$ & $7.013 .3 \mathrm{~kg}$ & 7.0 .33 & 0.62 \\
\hline 3. Hg Li (Li) & $238 \mathrm{gal}$ & 478 & 0.91 \\
\hline 4. TRU & $16.85 \mathrm{~kg}$ & 16.85 & 0.00085 \\
\hline 5. LLWW & $11.7(\mathrm{k}) \mathrm{kg}$ & $11,7(k)$ & 0.59 \\
\hline 6. Hydrated oxide sludge & $16,075 \mathrm{gal}$ & 65,662 & 61 \\
\hline 7. $\mathrm{Na} / \mathrm{K}$ nitrate sludge & $30.149 \mathrm{gal}$ & $2.52,678$ & 114 \\
\hline $\begin{array}{l}\text { 8. Machinery, construction } \\
\text { metals, steel drums }\end{array}$ & $6.58 .622 \mathrm{~kg}$ & $6.58,622$ & 428 \\
\hline $\begin{array}{l}\text { 9. Construction bricks, } \\
\text { concrete asbestos }\end{array}$ & $87,467 \mathrm{~kg}$ & 87,467 & 83 \\
\hline 10. $\mathrm{NaOH}$ & $859 \mathrm{gal}$ & 6,948 & 3.3 \\
\hline 11. Acids ( $\mathrm{HCl}, \mathrm{HF})$ & $1,255 \mathrm{gatl}$ & 4.728 & 4.8 \\
\hline 12. Cemented organics (cement only) & $4.182 \mathrm{gal}$ & 16,694 & 15.8 \\
\hline $\begin{array}{l}\text { 13. Miscellaneous organics, } \\
\text { combustibles (incl. } \# 12 \text { ) }\end{array}$ & 18.724 gal & 20.172 & 71 \\
\hline 14. Organics in silicate sludge & $85,535 \mathrm{gal}$ & $1.086,781$ & 362 \\
\hline 15. Halogen Salts & 0 gal & & \\
\hline 16. Animal remains & 0 ga! & & \\
\hline 17. Butyl stearate & O g gill & & \\
\hline 18. Phenyls & (1 |iil & 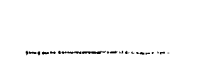 & $\ldots$ \\
\hline Tintal & & 2.222 .4 .49 & 1.146 \\
\hline
\end{tabular}




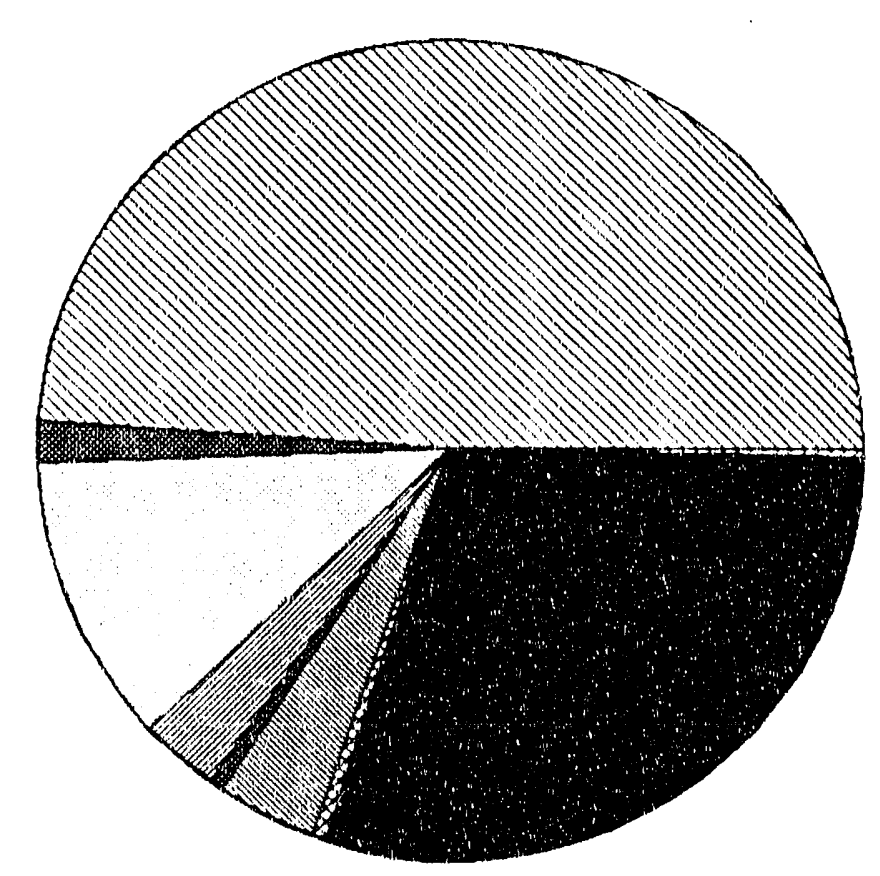

Legend

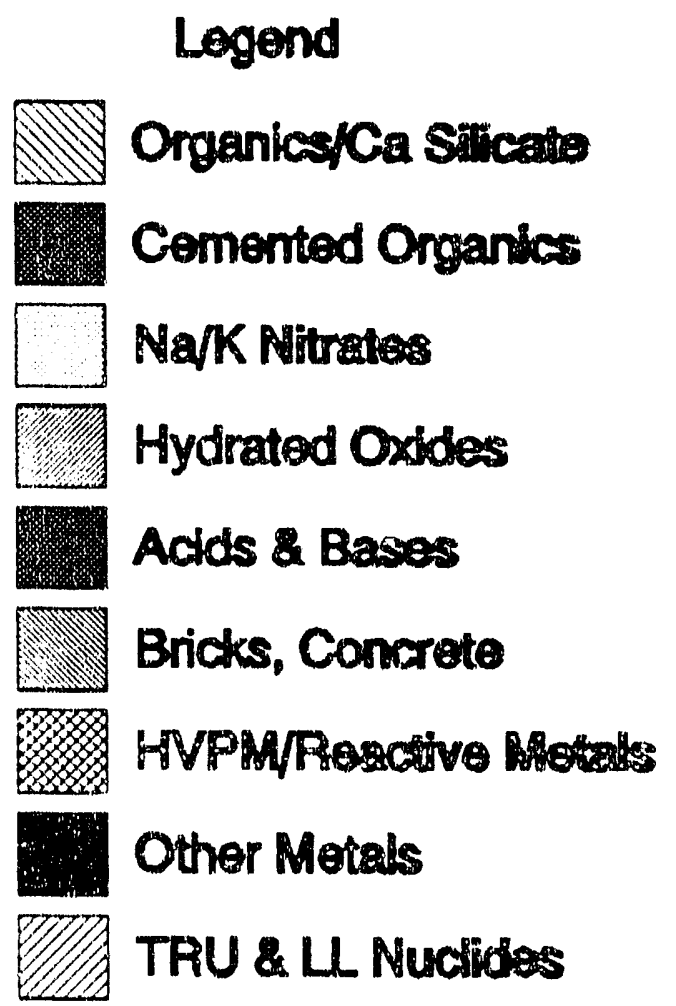

Figure 2-2. Relative mass fractions of matcrial categories of Pit 9. 


\subsubsection{Potential As-Found Process Considerations}

If the relative masses and volumes of the other pits are similar to Pit 9, as assumed above, the large majority of the mass of the waste in the pit is composed of (a) organics in a calcium silicate sludge, followed by (b) low-reactivity metals, (c) the nitrate sludges, and (d) the hydrated oxides. This sum comprises over $80 \%$ of the mass and excludes contaminated or clean adjacent soil. The TRUW and LLW components comprise less than $0.5 \%$ of the waste mass. It must also be recognized, however, that various materials may be concentrated locally; henee, large swings in waste streams of retricved concentrations could occur.

A preliminary discussion of general incineration and melting processing methods and/or problems resulted in the following. Note that organics are to be combusted, "solid" metal oxides to be dissolved in the slag, volatile metals and oxides to be collected in the offgas system, and other inorganic salts to be converted to oxides or collected in the offigas system. The TRU, LL, Na, NaK, $\mathrm{Ph}, \mathrm{Zn}$, and Li should ix readily oxidized, if not already oxidized or separated but by some other process. The $\mathrm{Hg}, \mathrm{Cs}$, and $\mathrm{ZnO}$ will likely appear in the off-gas and must be collected, along with any other volatile oxides or metals. The hydrated metal oxides and calcium silicate sludge should not present significant problems. The nitrate sludges will have to be treated carefully to prevent explosive reactions in the reactor. The material safety data sheets (MSDS) indicate that the nitrates could explode when heated. Preprocessing at lower temperatures is an option. The ecmented organies can result in irregular combustion reactions and can also erupt or explode; therefore, they should be redued to two inch or smaller chunks. The process will probably generate a dust which could result in explosions if not handled properly. Any uncemented organics may need to be fed into the reactor in appropriate amounts, but should not provide any unusual problems. The same is true of concentrations of acids $(\mathrm{HCl}, \mathrm{HF})$ or bases ( $\mathrm{NaOH})$. If mixed and heat treated with soil and lime, the HF may be reduced to calcium fluoride, which can be dissolved into the iron-enriched basalt (IEB) more easily than the chlorides. The large amount of stecl from machinery and construction could be separated from the slag and tapped. The bricks, asbestos, and other non-metallic construction materials would be part of the slag. The particulat chemical form of the materials is not as important as which elements are involved when using incineration and melting processes.

The major potential prohlem materials are those which cause discontinuities in the process: cruptions, explosions, unwanted (premature) oxidation, or strong reactions in processing units. The major potential contributors to discontinuities are the nitrate sludge (can erupt at moderate temperalures) and the eemented organics (can erupt when heated or oxidized). These materials will probahly require separation for special preprocessing. The effects of other materials which may usually be considered to be bad actors (acids, NaK, ete.) are dampened out here because of the large amount of soil which will be processed with these materials. Other polentially toxic materials (eg.. $\mathrm{Hg}$ or Cs-137) can be processed in the ofl-gas which is discussed under processing in a different siction.

A preliminary summary of the expeced problems and probable solutions is listed in Table 2-3.

\subsubsection{Volume Reduction Considerations}

The relative mass and velume fractions of TRUW and associaled soil are illustraled in figure $\$-3$. The mass and volume fractions are similar because of similar densities. The various volumes of waste and soil for Pit 9 are summarized in Table 2-4. Estimated volume reduetions in the form of a compaction ratio are calculated. It appears that the volume reduction considering only the 
Table 2-3. Expected potential problems and possible fixes for the various malcial catcgories of the input wasste streams. Note that all substances may have radiation-hazard problems. Most of the reaclive metals and radionuclides should be in the oxide state.

\begin{tabular}{|c|c|c|c|}
\hline \multicolumn{2}{|c|}{ Matcrial (atcgory (Pll9) } & \multirow{2}{*}{$\frac{\text { Ixpected Prohicm }}{\text { high reactivily }}$} & \multirow{2}{*}{$\frac{\text { Potential liax }}{\text { dilution in soul and oxidec/dissolve in slag. }}$} \\
\hline 1. & $\mathrm{Na}, \mathrm{NaK}, \mathrm{Mg}, \mathrm{I}, 1$ & & \\
\hline 2. & Ph. Zn & high volatility & $\begin{array}{l}\text { oxidize/collect in slag or collect in offigas } \\
\text { system. }\end{array}$ \\
\hline 3. & Hgli batteries & high reaclivity & $\begin{array}{l}\text { dilution in soil, Ilg pollutant collect in off-gas } \\
\text { system. }\end{array}$ \\
\hline 4. & TRU (Pu, Am) & a-radiation & $\begin{array}{l}\text { deted of limit exposure, oxidtize/dissolve into } \\
\text { slag. }\end{array}$ \\
\hline 5 & $\begin{array}{l}\text { LI.W (U. MIPP, MAl:) } \\
\text { C.S-137, ctc. }\end{array}$ & $\beta / \gamma-r a t d a t i o n$ & $\begin{array}{l}\text { detect to limit exposure, oxidize/dissolve into } \\
\text { sligg, collect in off-giss. }\end{array}$ \\
\hline 0. & Ilydrated oxicle sludge: & hydratc eruption & dilute with soil and dissolve in slag. \\
\hline 7 . & $\mathrm{Na} / \mathrm{K}$ nitrate sludgr & high-I reactivily & $\begin{array}{l}\text { low'-l roast lo get oxides, dissolve oxides in } \\
\text { slag. } N()_{x} \text { processed in oll-gas. }\end{array}$ \\
\hline 8. & $\begin{array}{l}\text { Mischincry, construction } \\
\text { melials, stecl drums }\end{array}$ & none & $\begin{array}{l}\text { oxidize and dissolve in sligg or lap melt and } \\
\text { parckigge. }\end{array}$ \\
\hline 9 & $\begin{array}{l}\text { Construction hricks, } \\
\text { concrete. ashestos }\end{array}$ & none & melt and dissolve in slagg. \\
\hline 10. & Nal)H & high reactivity & dilute in soil, oxidize and dissolve in slang. \\
\hline 11. & Acids $(11(\%, 111)$ & high reascisily & dilute in soil, oxidize and dissolve in slang. \\
\hline 12 & cemented organics & high-I cruption & $\begin{array}{l}\text { crush, incincrate, and dissolve ash/oxides in } \\
\text { sligg. }\end{array}$ \\
\hline 13. & $\begin{array}{l}\text { Miscellanecius organics, } \\
\text { combusubles }\end{array}$ & irregular combustion. & $\begin{array}{l}\text { preprocess w/wo soil, loxic incinerate } \\
\text { (rolary kiln), dissolve ash/oxides in slag. }\end{array}$ \\
\hline 14. & $\begin{array}{l}\text { ()rganks in sillcale } \\
\text { sludge }\end{array}$ & proper oxidation & $\begin{array}{l}\text { meller off-gass incmeration, or rolary kuln, } \\
\text { reatet with oxides and dissolve in slag. }\end{array}$ \\
\hline 15 & Halogen silis & high reaclivily & dilution with sosil, oxidire, dissolve in slag. \\
\hline 16. & Aismal remans & conlammonation & $\begin{array}{l}\text { dilution with sonl, oxudize, dissolve oxidies in } \\
\text { sligg. }\end{array}$ \\
\hline 17. & Buty| stcarille & «xis)y & $\begin{array}{l}\text { dilution with soll, oxidize, dissolve ixides in } \\
\text { slagg. }\end{array}$ \\
\hline $1 \mathrm{~s}$ & Phonyls & loxkity & clilutum with soll, axidize. \\
\hline
\end{tabular}


Table 2-4. Various volumes and calculated volume reduction or compaction ratios for Pit 9 based on estimated volumes and masses.

Volume Identity

Dense Waste (Table A ${ }^{10}$ )

Extraction Volume

Container Volume

Net Soil with Waste

Underburden soil

Overburden soil

Total soil

Compaction Ratio Taken

Soil Only

Waste Only

Waste + Entrained

Waste + Entrained + Under

Waste + All Soil

$\frac{\text { Volume }}{\left(\mathrm{ft}^{3}\right)}$

$40,482 \quad 1,146$

$342,416 \quad 9,696$

$150,690 \quad 4,267$

$191,726 \quad 5,429$

$149,807 \quad 4,242$

$256,812 \quad 7,272$

$598,345 \quad 16,943$
Value

$\operatorname{slag}(S . G .=3.2)$

soil $($ S.G. $=2.0)$

Container Volume

Dense Waste

Extraction Volume

$\overline{\text { Waste + Entrained/1.60 }}$

Extraction + Underburden

Waste + (Entraired + Underburden)/1.60

Extraction + Underburden + Overburden

Waste + (All Soil)/1.60)
$2.13 / 1$

$1.94 / 1$

$3.72 / 1$

$1.81 / 1$ 
containers and the contained waste is about 4-to-1. If the surrounding soil (excluding overburden and underburden) is included with the waste, the compaction ratio is about 2-to-1. (The compaction of the soil from its natural field density is about 1.6-10-1.) Including the over-and underburden soil decreases the volume reduction to approximately 2-to-1. The density difference between slag (specific gravity about 3.2) and the soil in the pit (specitic gravity about 2.0) giving a volume reduction factor of $3.2 / 2.0=1.6$ has been considered in the above calculations. The minimum volume reduction is, therefore, about 2-to-1, on an average, assumed homogeneous basis. The volume loss of organics and other volatile matter has been neglected in this conservative calculation.

If all the TRUW (without soil) were mixed to obtain a homogeneous waste stream input; combusted to remove the organies, $\mathrm{NO}_{\mathrm{x}}$ from the nitrates, and halides; and the remainder oxidized; the final waste form would solidify to a glassy rock with an average composition of approximately $38 \%$ silicon oxide, $7.4 \%$ aluminum oxide, $34.5 \%$ iron oxide, $8.3 \%$ calcium oxide, $4.6 \%$ magnesium oxide, $4.8 \%$ sodium oxide, and $2.4 \%$ potassium oxide." This composition was called the "Average TRU-contaminated Waste" composition for the RWMC and is designated A-(). The "()" indicates the wt \% of RWMC (basaltic) soil in the final waste form: A-40) indicates $40 \%$ RWMC soil and $60 \%$ average TRUW. If the RWMC soil were melted and solidified, it would form a ferro-aluminosilicate glass/rock (partly amorphous glass and partly crystalline rock). The A-() composition gives an iron-enriched aluminosilicate glass/rock; henee, the composition of the waste is very similar to the soil with designations between $\mathrm{A}-()$ and $\mathrm{A}-100)$ spanning the limits.

A-1) will make a good waste lorm, but a particular melter batch will probably not have the aterage waste composition. If it does, a $4 / 1$ volume reduction is attainable. If not, the amount of contaminated soil added to obtain an appropriate composition will reduee the volume reduction ratio (1) no worse than $2 / 1$.

\subsection{As-Separated Classification}

\subsubsection{Basis for the As-Separated Classification}

The classification of input watste streams for the As-Separated classification is based on the recommendations of the SDS (see Reference 1). Only two of the treatment systems proposed in the SDS fall within the work scope of the JHM/PHM applicalions, the incineration and melting with LLW Presort (2-EG-1) and with LLW Postsort (2-EG-4). The difference between the two is that in the lirst, after retrieval, an on-line assay is made to separate TRUW and I.L.W wastes prior (o) other sorting procedures common to both systems. (Figure A-1 gives the process flow diagram for the presort system.) The common sorting procedures occur at different stages and essentially separate into three classes: (a) TRUW for packaging and storage in a TRUW repository, (b) LLW wistes for separate treatment (from 'TRUW) and subsecuent I.DR storage, and (c) clean off-gas, water or soils for unrestricted disposal.

The recommendation of the SDS is for the Postsont option (see Figure A-2) because of estimated cost savings. In the Postsorl option, the On-Line Assay between TRUW and LLW and, herrec, the LLW Processing Subsystem (S-1T-3, as shown in Figures A-7 and A-8) are eliminated. With this option, the disposal options are the same, but the assity and separation of TRUW and LLW oceur after the decontamination of metals, incineration of eombustibles, and melting and dissolution.

Prior to retricval, the trench or pit would be characierized by available methods to identily probable locations of concentrations of TRU and LL sources. The Retrieval Subsystem (S-BE-4 as 
shown in Figures A-3 and A-4) would then scparate the soils from the non-soil containers, machinery, etc. A Soils Processing Subsystem (S-EB-2 as shown in Figures A-5 and A-6) then separates the soil into TRU-contaminated soil, LL-contaminated soil, clean soil, and clean water. The non-soil containers are opened and sorted into metallic, non-metallic/combustible, and combustible streams. The combustibles are shredded and incinerated, followed by ash separation and off-gas treatment. A Metal Decontamination Subsystem (S-EG-1 as shown in Figures A-9 and A-10) sorts into TRUW metals, LLW metals, liquid/residue, and clean water. All TRU-contaminated soil, TRUW metals, combustible ash, olf-gals and metal-decontamination liquid/residue, and shredded non-combustible waste are routed to the melting furnace. Final TRUW products are packaged and sent to TRUW storage. LLW wastes are routed to a LLW treatment facility with tinal disposal under LDR. Clean, treated off-gases, water, and soil are disposed of without restrictions. Additional details are discussed elsewhere (see Reterence 1).

\subsubsection{Initial As-Separated Classification}

The Presort process flow diagram (sec Figure A-1) can be expressed in terms of a simplified component waste streams as shown in Figure 2-3. For Postsort, the LL.W materials stream would be combined with the appropriate TRUW combustibles, non-combustibles, and metal wastes. Rearranging the materials categories classified in Table $2-2$ into the component waste streams results in the preliminary As-Separated classification presented in Table 2-5. The nitrates are included with the combustibles because they are oxidizers, can react lavorably with the silicate sludge to form a good final waste form, and can give potential processing problems. The table also lists "soil" on the rough assumption that the TRU-contaminated soil is possibly contained in the net soil in the waste (see Table 2-4), the LLW materials are possibly contained in the underburden soil or equivalent amount, and the clean soil may be equivalent to the amount of the overburden soil. The molecular weights used to estimate the number of moles are given in parenthesis and are based on some component(s) in the material. The soil is assumed to be a "calcium-oxide" basalt. The number of moles is useful in estimating the quantity of additional materials that will be required to complete the reactions or dissolution.

\subsubsection{Potential As-Separated Process Considerations}

The As-Separated Case represents a first cut at dividing the total waste and related soil to reduce the TRUW storage, to use incincration techniques where possible, and to separate the LLW from clear materials. Considering the comments in Section 2.1.4, it appears that it may be desirable to have more than one incinerator or ractor to convert the TRUW combustibles to desired forms. Also some additional feedstock processing will be necessary with different feedstocks requiring different processes. In brief, the preliminary As-Separated classification appears to be belter than the As-Found, but needs additional retinements.

Polential refinements are shown in the preliminary llow diagram of Figure $2-4$ which includes leatures of both the Presort and Postsort options. The combustibles are shown as four streams in Figure 2-4: miscellaneous organics, cemented organics, organics in silicate sludge, and the $\mathrm{Na} / \mathrm{K}$ nitrates. The animal remains, Butyl stearate, and phenyls of Table $2-5$ or other organics not explicitly identified here could be added to one or more of these streams as appropriate. The miscellaneous and eemented organics need 10 be processed in a crusher or shredder prior 10 incineration. Ash is recycled to the silicate melter \#1 through one of the other pretreatment processors. Off-gas treatment is via traditional mixed waste incineration methods. The organics in silicate sludge are proposed to be mixed with some TRli-contaminaled (or other) soil prior to entering the melter to minimize the effect of small eruptions. Additional soil maly be added as needed. 'The nitrates are 


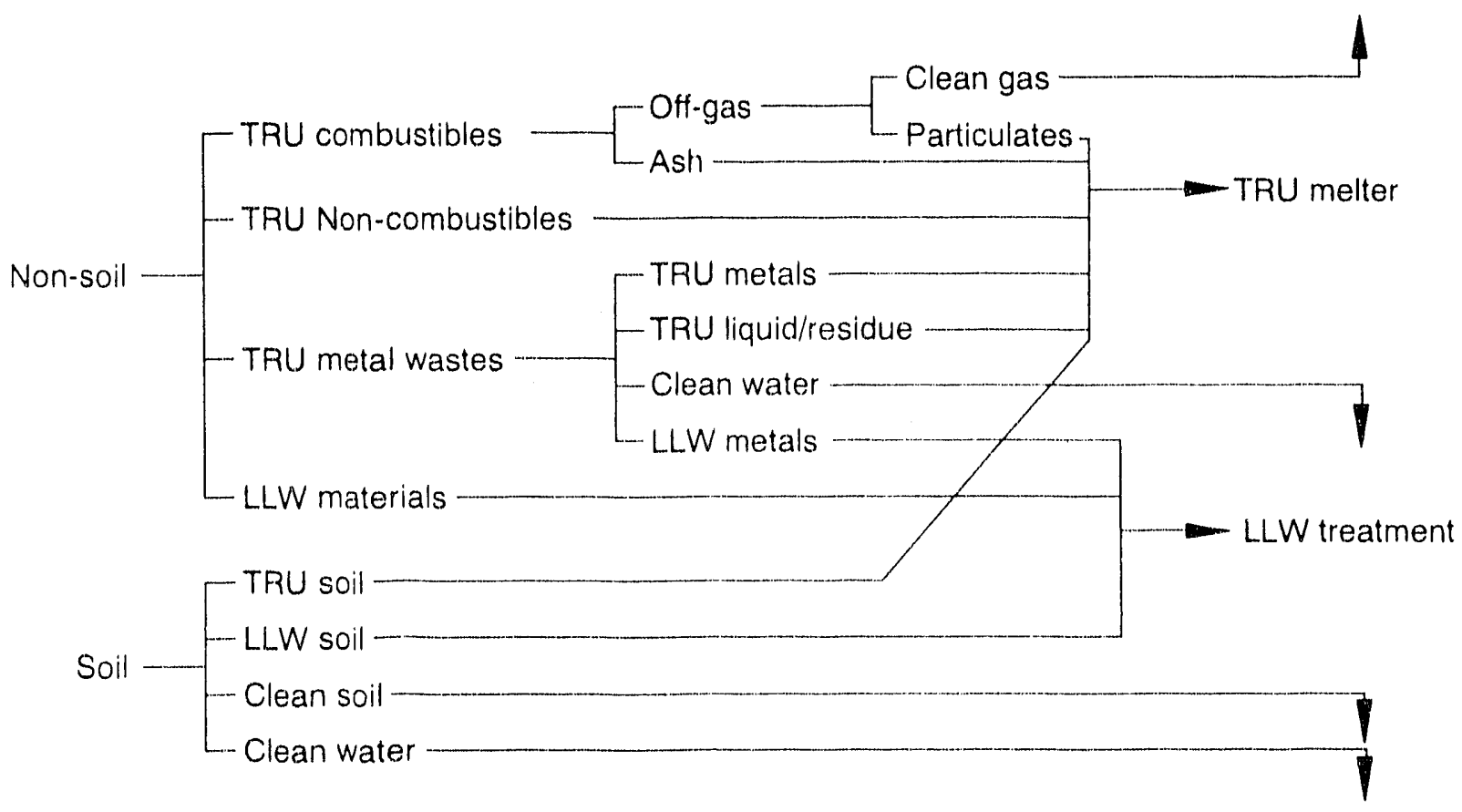

N92 0080

Figure 2-3. Component waste streams for As-Separaled classification based on the Presort Option in Figure A-1. 
Table 2-5. Initial As-Separated clatssilication of input waste strcams. Mass/Mole data is for Pit 9 as estimated from Tables A.10 and A-11. Pit 9 has no record of LLW from the INEL. The basis for the molecular weight is given in parenthesis.

\section{Malcrial Catciory}

\section{TRUW Combustibles}

7. $\mathrm{Na} / \mathrm{K}$ nilrate sludge

12. Cimented organics (Portland cement only)

13. Miscellancous organics (incl. \#12, assm d $\left.\mathrm{C}^{\circ} \mathrm{Cl}_{4}\right)$

14. Organics in Ca silicate sludge $\left(75 \mathrm{CaSi}_{3}+25 \mathrm{C}_{2} \mathrm{H}_{11}\left(\mathrm{O}_{2}\right)\right.$

16. Animal remains

17. Butyl stcarale

18. Phonyls

\section{TRUW Non-Combustibles}

6. Hydrated oxide sludge $\left(\mathrm{Al}_{2} \mathrm{O}_{3} \cdot \mathrm{H}_{2}\left(\mathrm{O}+\mathrm{Fe}_{2} \mathrm{O}_{3} \cdot \mathrm{H}_{2} \mathrm{O}\right)\right.$

9. Const. bricks concrele asbestos $\left(\mathrm{CaSiO}_{3}\right)$

11). $\mathrm{NiOH}$

11. Acids (HCl, HI)

15. Hakgen Salts

\section{TRUW Metal Waste}

1. $\quad \mathrm{Na}, \mathrm{NaK}, \mathrm{Mg}(\mathrm{NaK})$

2. $\mathrm{Pb}, \mathrm{Zn}(\mathrm{Pb}$ in $\mathrm{Pit}$ 9)

3. Hu, L.i (Li in Pit 9)

8. Machinery, constrution melals, slect drums (lie)

\section{Radioactive Malerials}

4. TRU (Pu-239)

5. LLWW (U.238)

\section{Soils $\left(\mathrm{SiO}_{2} \cdot \mathrm{FeO} \cdot \mathrm{Al}_{2} \mathrm{O}_{3} \mathrm{CaO}\right)$}

19. Entrained Soil (Assumed TRUW Soil)

2). Underburden Soil (Assumed LI.W)

21. Overburden Soil (Assumed ( kain)
2,777

12,211

()

()

()

552

754

174

175

34

56 $\begin{array}{lll}56 & 0.58,622 & 11,761\end{array}$

,$(13.3$

() 


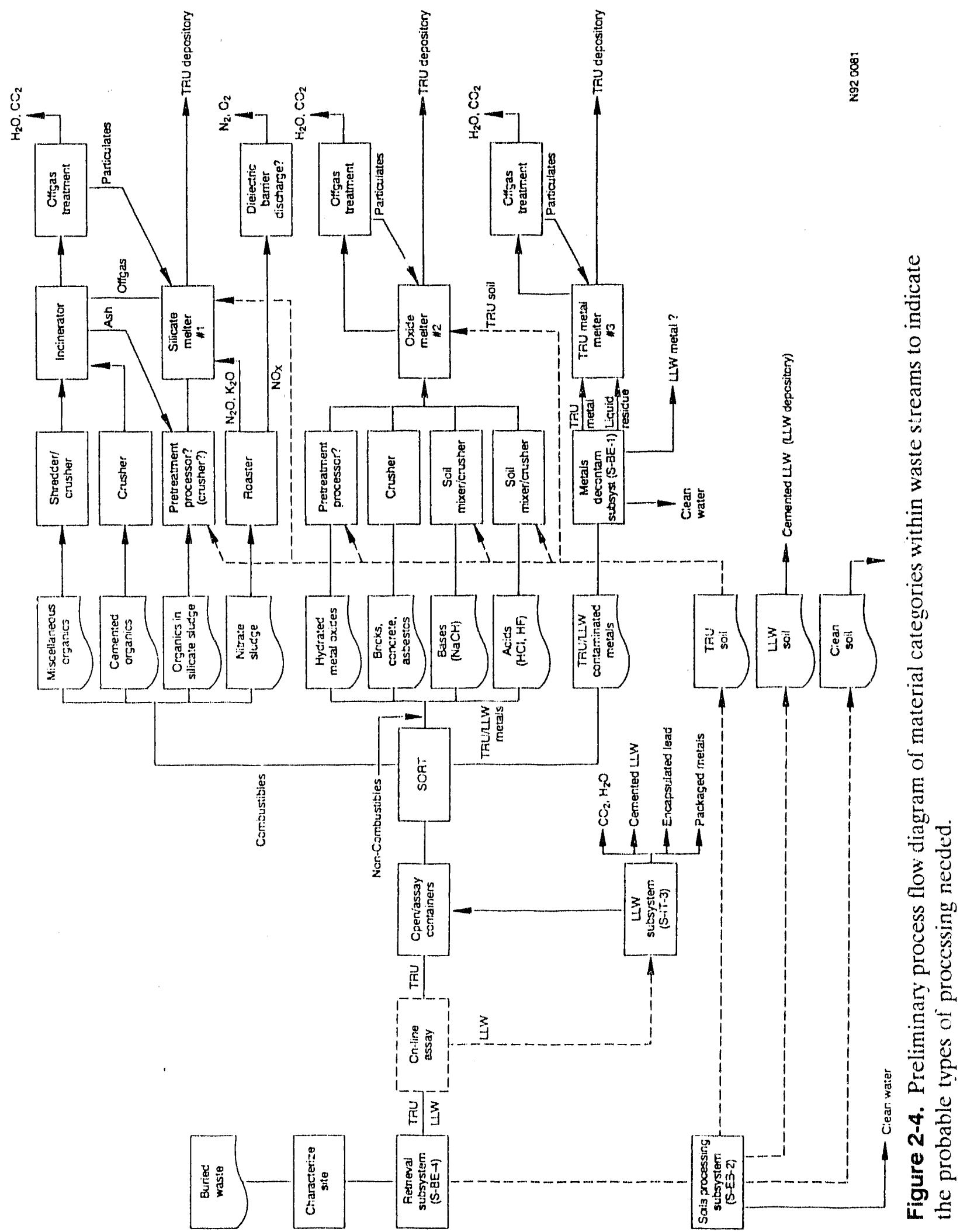


foasted at low temperature to convert them to the oxides and $\mathrm{NO}_{x}$. The oxides are added to the melter; whereas, the $\mathrm{NO}_{x}$ needs 10 be processed to $\mathrm{N}_{2}$ and $\mathrm{O}_{2}$ (c.g., by the dielectric barrier discharge ${ }^{7,8,9}$ or the gliding are discharge ${ }^{10}$ or more conventional methods). The material from the melter would be packaged, assayed, and stored (see Figures A-1 or A-2).

The non-combustibles are also shown as four streams in Figure 2-4: hydrated metal oxides, construction materials (bricks, concrete, asbestos), bases $(\mathrm{NaOH})$, and acids ( $\mathrm{HCl}, \mathrm{HF})$. Other non-combustibles could be added to one of these streams. The halogen salts could probably be added to one of these streams or to a combustible stream if strong reaction effects are expected. For the lour streams, the pretreatment in a crusher is similar. Mixing with soil could probably be done sequentially in the same crusher while feeding the oxide melter \#2. Additional soil can be added as needed to give the appropriate melt composition.

The TRUW and/or LLW metallic wastes would be processed by the Metals Decontamination Subsystem, with the LLW metals being packaged for LDR disposal, TRUW metals, liquids and residue going to the TRUW metal melter \#3, and clean water being recycled for use in various subsystems.

Not considered in the above simplified scheme are details in the processes, including off-gas treatment of high vapor-pressure motals (HVPM), the addition of lluxes to lacilitate dissolution or affect viscosity, and packaging considerations. Offgas collection and treatment options are being considered by others. ${ }^{11}$ The actual methods, which have to be specific to the resulting process, need to be resolved in a later design stage.

Several melters have been consiclered in this preliminary waste stream analysis. A number of such systems may be needed to handle the quantity of waste in the proposed SDS time period. Each melter system will predominantly handle similar types of waste streams so that the monitoring and control system techniques will be similar on each melter and for each set of operators. Systems could be modified to handle other streams depending on loading factors and maintenance.

\subsection{Recommended Classification of Waste Streams}

It is premature to determine the optimum waste stream classilication prior to additional information on the details of the processes. This must involve a systems design analysis that integrates the input waste streams, the desirable final waste product, and the processes necessary for particular waste streams. From the As-Separated discussion, it appears that a number of different matcriat streams could be input sequentially or encurrently to the same preprocessor (shredder/crusher) and be blended and melted to obtain the desired high quality waste product. The amount of some of the components will depend to some extent on the amount of other components and the particular process or recipe to be used; hence, the input waste stream matrix if extensive sorting is to be used will also have to be determined later.

Preliminary reviews of this report have indicated that it will be very difficult and expensive to do sorting and much more to do sophisticated sorting. Based on the discussion above it appears that a "logical" sort of combustibles and noncombustibles per Table $2-5$ may not be practical. If sorting is to be done at all, a more pratical sorting could run most of the questionable materials into a thermal desorber/incinerator system lirst as "combustibles," with the identiliable concrete, bricks asbestos, etc. as "noncombustibles," and easily sorted metals (by magnets or mass/conductivity methods). The soils could be added as needed for buffering or composition controt. The resulting 
distributions are shown in Table 2-6. The radionuclides are assumed to be distributed throughout the other materials.

The mass of the noncombustible waste stream is now about $10 \%$ of the combustible stream and could be included to provide additional buffering and simpler sorting. Adding the structural metal stream to the other two would increase the heating requirements, but this metal would not melt or vaporize, hence, the incineration process (prior to the afterburner) could provide a means of cogeneration to preheat the metal and noncombustibles with the combustion heat just prior to entering the melter. Melter process time can be thus substantially reduced, giving greater throughput per melter. If the combustion air is countercurrent to the waste stream, it could also act as the thermal desorber near the entrance of the incinerator. With this integrated waste stream, sorting is unnecessary. The TRU-contaminated soil can be either injected separately or with the heterogeneous waste stream to obtain an appropriate lïnal waste form. 
Table 2-6. Recommended as-separated classification of input waste streams.

Estimated

Matcrial Category

Molecular

\section{TRUW Combustibles}

$1 \mathrm{Na}, \mathrm{NaK}, \mathrm{Mg}(\mathrm{NaK})$

$2 \mathrm{~Pb}, \mathrm{Zn}(\mathrm{Pb}$ in Pit 9)

$3 \mathrm{Hg}, \mathrm{Li}$ (Li in Pit 9)

6 Hydrated oxide sludge

$\left(\mathrm{Al}_{2} \mathrm{O}_{3} \cdot \mathrm{H}_{2} \mathrm{O}+\mathrm{Fe}_{2} \mathrm{O}_{3} \cdot \mathrm{H}_{2} \mathrm{O}\right)$

$7 \mathrm{Na} / \mathrm{K}$ nitrate slucge

$10 \mathrm{NaOH}$

11 Acids $(\mathrm{HCl}, \mathrm{HF})$

12 Cemented organics (Portland cement only)

13 Miscellaneous organics (incl \#12, assm'd $\mathrm{CCl}_{4}$ )

14 Organics in Ca silicate sluage $\left(75 \mathrm{CaSiO}_{3}+25 \mathrm{C}_{2} \mathrm{H}_{6} \mathrm{O}_{2}\right)$

15 Halogen Salts

16 Animal remains

17 Butyl stearate

18 Phenyls

\section{IRUW Non-Combustibles}

9 Const bricks, concrete asbestus $\left(\mathrm{CaSiO}_{3}\right)$

\section{TRUW Mctal Waste}

8 Macninery, construction metals, steel drums (Fe)

\section{Radioactive Materials}

$4 \quad$ TRU (Pu-239)

$5 \operatorname{LLW}(\mathrm{U}-238)$

\section{Soils $\left(\mathrm{SiO}_{2} \cdot \mathrm{FoO} \cdot \mathrm{Al}_{2} \mathrm{O}_{3} \cdot \mathrm{CaO}\right)$}

19 Entrained Soil (Assumed TRUW Soil)

20) Underburden Soil (Assumed LLW)

21 Overburden Soil (Assumed Clean)
240

238

Calculated Estimate

Mass (kg)

kg-Moles

62

207

119

91

40

27

66

152

89

3,469

7,033

478

65,662

56

34

68

552

252,678

6,948

4,728

2,777

174

175

16,694

253

20,172

133

$1,086,781$

12,211

()

0

0

()

()

0

()

116

87,467

754

56

658,622

11,761

290

$10,876,093$

37,504

290

$8,498,143$

29,304

290)

$14,568,244$

50,235
0.07

49

$11,700)$ 


\section{CRITERIA AND REQUIREMENTS FOR FINAL WASTE FORM}

\subsection{Summary}

Development of a host solid for the immobilization of nuclear wi les and non-nuclear hazardous waste has focused on various vitreous/ceramic waste forms including borosilicate, high silica glass (Pyrex), high alumina silicate glasses, iron-riched basalt (IEB), glass-ceramics, and phosphate glasses. Consideration of all parts of the waste disposal system ensures that the final product will safeguard the public, and that the production process used will be safe, efficient, and environmentally sound to operate. The system engineering development approach requires that parameters affecting product performance and processing conditions be considered simultaneously. Parameters alfecting product performance, such as chemical stability, waste form kachability, thermal stability, mechanical duratility. impact resistance to generate breathable lines, radiation damage resistance, and environmental compatibility, must be ensured and optimized, relative to prosessing parameters such as meit temperature and viscosity, electrical and thermal conductivities of the melt, waste solubility, melt corrosivity. and volatility of high vapor hazardous species.

Numerous sysrem research approaches have indicated that borosilicate glasses (BSG) are, overall, the most studied glasses for immobilization of nuclear wastes. Some phosphate glasses are highly durable; but the glass melts are highly corrosive 10 the melter even at $9000^{\circ} \mathrm{C}$, have poor thermal stability, and have low solubility for many waste components. On the other hand, iron enriched basaltic (silica composition ranges from 40-60) wt ${ }^{\circ}$ ) waste forms, glass-ceranics, and high alumina silicates have high chemical stability, high thermal stability, high mechanical stability, and gond entironmental compatibility, but their associated high melting temperatures potentially increase the volatilization of hazardous waste species during processing. The fabrication of these final waste forms requires the use of very high temperature melters. The borosilicate glasses rnelt at much lower temperatures than other high temperature waste forms and are generally less corrosive to the melter. The low melting temperatures of borosilicate glasses minimize excessive volatilization of hazardous species from the melt.

However, there are sericus draubacks to the fabrication of BSG final waste forms. The BSG labrication process requires a known waste stream composition and is incapable of handling a highly varying heterngeneous waste streams. Because of the low processing temperatures, BSG processes cannot handle refractory materials such as iron and basaltic soil. The fabrication of BSG final waste furms required large additions of $\mathrm{B}_{2} \mathrm{O}_{3}$, alkaline oxides. alkaline eirth oxide, and glass frits. The INEL RWMC huried TRU mixed wastes and the associated contaminated soil are heterogeneous and their compositions vary between extremes. Retrieving and converting the RWMC buried TRU mixed wastes to BSG is impratical and impossible. The process would require costly efforts to separate all the high melting metals. a large addition of glass forming materials, and a tight control of the waste sroam compositions. The large quastity of glass forming materials needed to fabricate BSG will not produce a volume reduction of the RWMC huried wastes and, potentially, the process would produce at high volume of the final waste form.

Based on the System Design Study (see Reference 1), the waste form must be a leach-resistant, high quality synthetic glass or rock and must satisfy the general requirements established for high-level watse forms to be disposed of in deep geological repository. The final waste form will also comply with the TRAMPAC (ransportation and packaging) requirements. From the design stand point, the final waste form must possess the follow ing characteristics: (a) chemical stability. (b) thermal stability. (c) rrechanical durability. (d) high leach resistance. (e) high impact resistance to gemerale hreathahle 
lines, (f) macroscopic homogeneity in terms of overall waste form propertics performance. (g) high waste loading capability, and $(h)$ high stability to internal $\alpha, \beta$, and $y$ radiation damage.

From the design stand point the final waste form must meet the following specific requirement assumptions: (a) plutonium and other TRUs will be dissolved, oxidized, and chemically incorporated into the silicate melt, (b) low-level wastes and/or fission products will be dissolved, oxidized, and chemically or physically incorporated into the melt. (c) HVPM will he either incorporated into the silicate melt or volatilized from the melter and collected down-stream of the melter unit for separate disposal, (d) the final waste form should enable a high concentration of $\mathrm{Fe}$ and $\mathrm{Al}$ to be chemically dissolved because they are the major components of the INEL TRU waste stream and this would yield maximum volume reduction, and (e) the tinal waste form will not contain organic residues and water of hydration so that hydrogen generation due to radiolysis will not become a problem because the tinal waste form is produced from very high temperatures.

In view of the above general and specific requirements. iron-enriched basalt (IEB) ${ }^{12}$ is a suitable final waste form to immobilize the INEL RWMC buried TRU mixed wastes. The IEB linal waste form possesses the following desirable critical characteristics (see Reference 6) as compared 10 BSG; (a) both fine-grained and coarse grained IEB final waste lorms have demonstrated a much betler leach resistance for uranium than BSG and high silicale glasses. (b) IEB waste forms generally exhibit better mechanical and thermal stability than BSG. (c) the IEB labrication process has high werance for all metals, including high melting temperature metals, (d) the IEB waste form is very accommodating to highly heterogencous waste streams with varying compositions. (e) IEB processes produce very high volume reduction for the RWMC TRU waste streams, and (f) properties of IEB final waste forms are comparable to the natural basaltic rock anakgue.

The INEL soil is basaltic and is among the waste streams at the site "herefore. the basaltic soil should be considered as the host matrix to fabricate IEB for immobilization and stabilization of the RWMC radioactive mixed hazardous wasles. The IEB previously studied at INEL should be reinvestigated and pursued more vigorously as a viable final waste form for the INEL buricd radioactive wastes.

\subsection{Nuclear Final Waste Form Development}

Development of linal glass waste forms for the solidilication sf nuclear waste began at different limes in the U.S. Canada, Europe, and the USSR. Dilferent glass formulation and processing methods were developed. The system approach to final nuclear waste form development must consider the parameters affecting the product performance. Table $3-1$ indicates desirable characteristics of the final waste form product. 'Table 3-2 lists desirable conditions during the processing of the waste in a melter.

The borosilieate glass formulations were developed in the U.S. between 1956 and 1957. The aluminosilicate glass formulations, were simultaneously heing develoned in Canada in 1957. Phosphate-base glasses were the last 10 he investigated and the first to be abandoned as a final waste form for nuclear waste. The evaluation of phosphate glisses demenstrated that the pessitive aspects if presessing. e.g. kow melling temperatures, were out weighed by other negative processing aspects-melt corrosiveness to the melece system and pour product performance. Later, glass-ceramic such as IEB (sec References 6 and 12 ) and eramic such as Synroc ${ }^{13}$ (a titanate-based material) were deweloped as tinal waste forms for the immobilization of nuckar wastes. These waste forms have compositions that paraliel the natural analogs which are stable in geological time scale. These 
Table 3-1. Desirable final waste form characteristics.

\section{Desirable product characteristics}

Chemical stability

Thermal stability

Mechanical durability

Impact resistance to generate breathable fines

Macroscopic homogeneity in terms of overall properties performance

Waste form insolubility

Resistance to radiation damage

High TRU and fission products retention in the final waste form

High hazardous metal retention in the linal waste form

Ease of waste form formulation

Table 3-2. Desirable process conditions for waste form development.

\section{Desirable process characteristics}

Appropriate Melt temperatures

Minimum Melt corrosivity

Maximum Waste loading

Appropriate Melt thermal conductivity

Appropriate Melt electrical conductivity

Appropriate Melt viscosity

High reproducability

Ease of radiation shielding and equipment handling

Minimum volatilization of hazardous high vapour pressure metals 
types of ceramic and glass-ceramic linal waste lorms are much more leach resistant under parallel test conditions and provide higher levels of assurane over a wider range of geological disposal temperatures than those applicable 10 borosilicate waste glasses. At present, research and development into all types of linal waste forms are still on going. Figure 3-1 attempts to present an overview of the historical development of nuclear final waste forms.

\subsubsection{Borosilicate Glass (BSG)}

The first glasses formulated for use in nuclear waste disposal were investigated by Goldman and others as early as $1956 .{ }^{14,15,16}$ They examined the calcium-aluminosilicate with boron oxide added to achieve a pourable glass at $13000^{\circ} \mathrm{C}$. The quality of the glass did not suffer from the incorporation of $\mathrm{ZrO}_{2}$ and $\mathrm{Fe}_{2} \mathrm{O}_{3}$, which were present in the nuclear wastes. Eliassen and Goldman (see Reference 15) considered the most promising vitreous systems for future development were boresilicate-based glasses, e.g. $\mathrm{CaO}-\mathrm{Al}_{2} \mathrm{O}_{3}-\mathrm{B}_{2} \mathrm{O}_{3}-\mathrm{SiO} \mathrm{O}_{2}$ and $\mathrm{CaO}-\mathrm{Na}_{2} \mathrm{O} \cdot \mathrm{Al}_{2} \mathrm{O}_{3}-\mathrm{B}_{2} \mathrm{O}_{3}-\mathrm{SiO}_{2}$, because these glasses were pourable at $13(N)^{\circ} \mathrm{C}$ and their quality did not suffer from the incorporation of nuclear waste materials.

Although the original BSG formulations were developed in the U.S., further development and testing of the vitritication process during the early 1960s were carried out primarily in Britain and Europe. ${ }^{17,18,19}$ In the mid-196), the Waste Solidification Enginecring Prototypes (WSEP) program was initiated at Pacific Northwest Laboratory (PNL) and demonstrated the overall ease of possibility and compositional flexibility of BSG for high-level wastes (HLW). ${ }^{20}$ Simultaneously, PNL demonstrated the capability of Joule-heated glass-melters (sce Reference 20) j. Other waste producers such as Savannah River Laboratory (SRL) built upon both European and U.S. experiences and utilized BSG as the preferred linal nuclear solid waste disposal form. ${ }^{21}$ Borosilicate glasses are alkali aluminosilicate which are fluxed with boron. The fower alumina content and the presence of boron lowers the melt viseosity and, hence, the processing temperature to below $11500^{\circ} \mathrm{C}$. This is low relative to that of other aluminosilicate glasses. In general practice, the viscosity of the melt is kept near 1(x) Poise for easy pouring. Besides lowering of the melt viscosity at a given temperature, boron also increases the solubility of many waste constituents in the silica-balsed glass. ${ }^{22}$ While maintaining thermal and mechanical stability ${ }^{2.3}$ of the glass, boron only decreases the chemical stability slightly ${ }^{24}$ relative to the highly durable, but much harder to process, high alumina silicate glasses.

The typical $\mathrm{BSG}^{25}$ (see Table 3-3) currently in use for the solidilication of nuclear waste is very different from the original Pyrex BSG. Since the borosilicate waste glasses contain 15-30 wt\% waste, much of the chemistry is still dominated by the chemistry of the alkali oxide-silica-boron oxide system. The alkali oxide is mainly $\mathrm{Na}, \mathrm{K}$, or a combination of $\mathrm{Na}$ and $\mathrm{K}$. Quite often, the alkali oxides are tailored to include alkaline earths, such as $\mathrm{Ca}$ and $\mathrm{Mg}$, 10 produce a glass melt with slightly higher melting temperatures. Alkaline earths are not strong charge carricers and will not increase substantially the electrical conductivity of the melt-a requirement for Joule-heated melting, while maintaining the mell lluidity. From Table 3-3. the compositional differences between the borosilicate waste glasses and Pyrex show that Pyrex has a much higher silica content and, hence, melts at a higher temperature. Pyrex is an extremely durable glass due to its high silica content. ${ }^{26}$ The high alumina silicate glasses. IEB, and glass-ceramics have comparable silica composition but the melting cemperatures of these hosts are considerably higher than BSC hecause of a higher composition in alumina and the alkaline earth sxides. In particular, the alkaline content in IEB is one of the lowest among other silicate glasses and its melting temperature is substantially higher than most other ylatsses. 


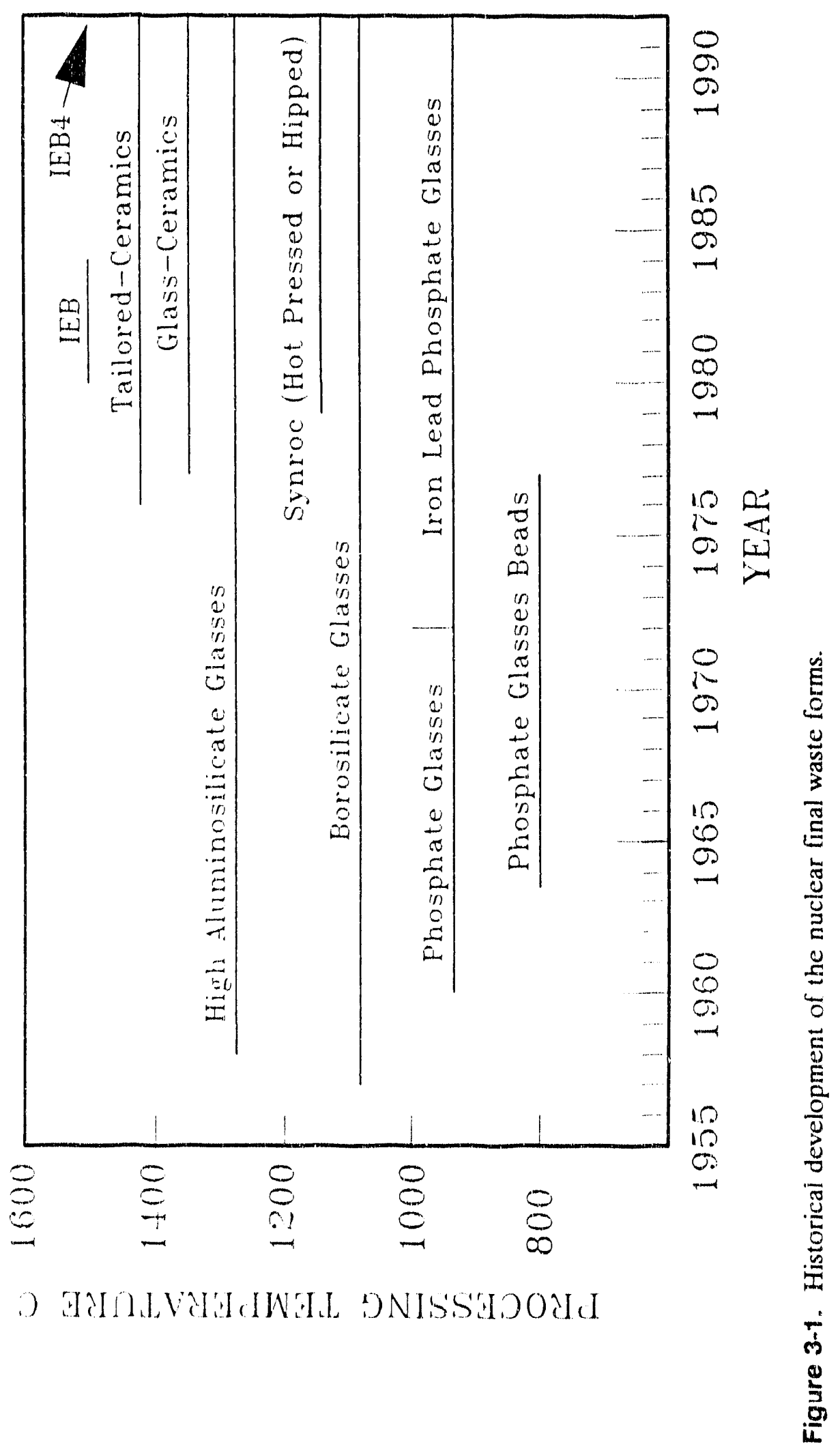


Table 3-3. Typical range of waste glass composition.

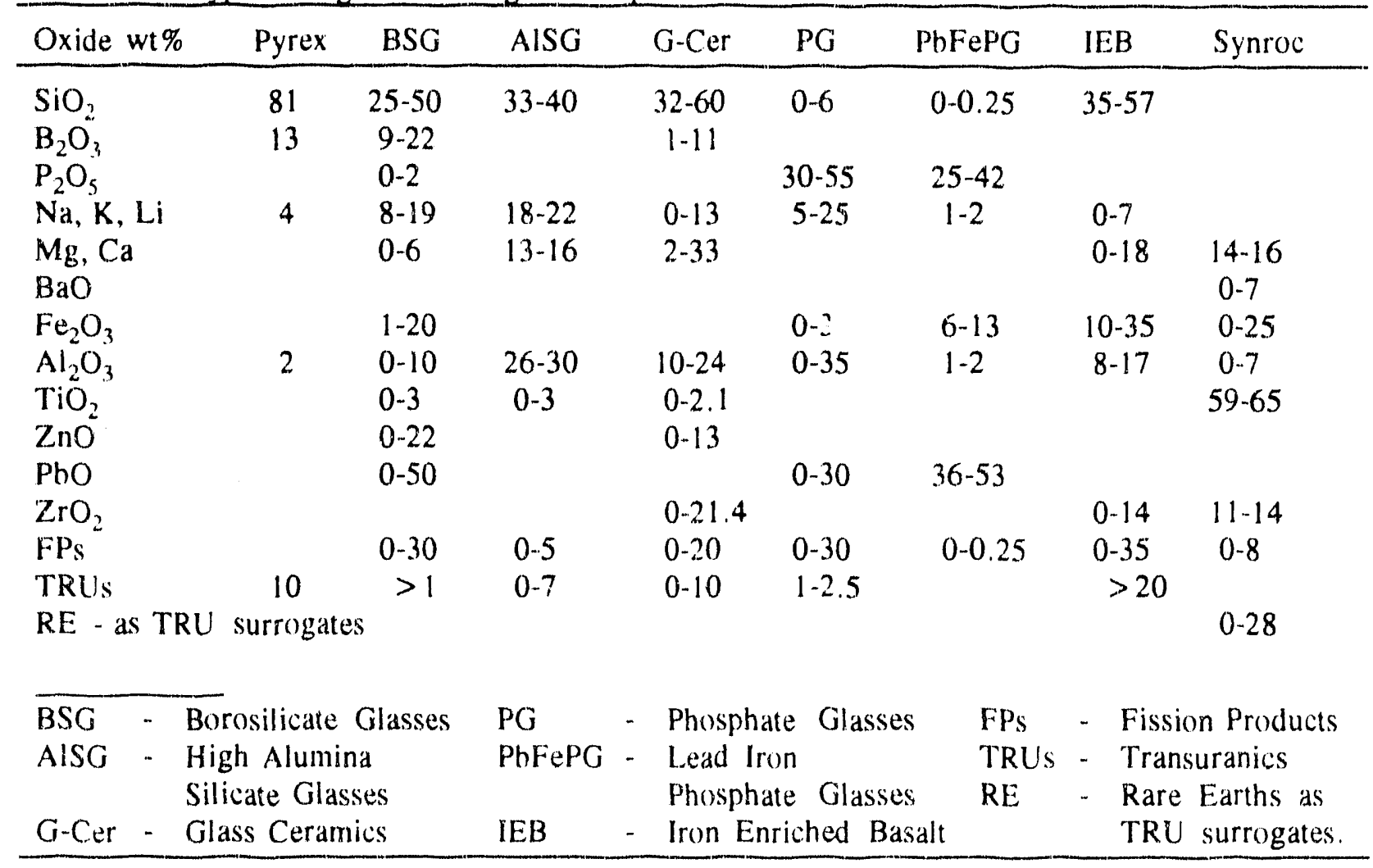


Table 3-4. Characteristics of different waste forms compared to BSG.

TYPES OF WASTE FORMS

Product Stability

\begin{tabular}{|c|c|c|c|c|c|c|c|}
\hline & Pyrex & $\mathrm{BSG}$ & $\mathrm{PG}$ & AlSG & G-Cer & IEB & Synrox: \\
\hline hemica & excello & goo & & excellent & ellent & lent & \\
\hline . & good & good & poor & excellent & excellent & excellent & \\
\hline ical & good & good & poor & excellent & excellent & excellent & excells \\
\hline
\end{tabular}

Process Characteristics

\begin{tabular}{lllllll} 
& Pyrex & BSG & PG & AlSG & G-Cer & IEB \\
\cline { 2 - 7 } & & & & & & \\
Melt temperature & $>14(0)^{\circ} \mathrm{C}$ & $<115()^{\circ} \mathrm{C}$ & $<1050^{\circ} \mathrm{C}$ & $>1350^{\circ} \mathrm{C}$ & $>1450^{\circ} \mathrm{C}$ & $>1500^{\circ} \mathrm{C}$ \\
Melt corrosivity & high & average & high & high & high & moderate \\
Melt viscosity & moderate & average & low & moderate & moderate & high \\
Waste solubility & moderate & high & moderate & low & high & high \\
Limit volatility & moderate & good & good & moderate & poor & poor
\end{tabular}

BSG - Borosilicate Glasses

AISG - High alumina silicate Glasses

PG - Phosphate Glasses

G-Cer-Glass Ceramics

IEG - Iron-Enirched Basalt 
Table 3-3 indicates the upper and lower oxide composition limits in the final waste form. Table 3-4 compares the system characteristics of different waste glasses. The borosilicate melts are generally less corrosive to the refractory materials of the glass melter than other nuclear waste glasses due to lower temperatures of fabrication or the absence of $\mathrm{P}_{2} \mathrm{O}_{5}$. The technology used for commercial waste glass fabrication can, therefore, easily be applied to the process of borosilicate glass. Under these considerations, borosilicate glasses exhibit favorable product performance as well as ease of processibility.

The product stability and the process characteristics of different linal waste forms use BSG as a reference baseline for comparison. The total amount of alkaline or phosphoric oxides (see Table 3-3) in each waste form and its eorresponding melt temperature were used as baseline criteria to rank the melt corrosivity to the melter system and the mell viseosity. The process characteristics for Synroc was not compared with other waste forms because the material was fabricated and consolidated under hot pressed conditions well below its melting temperature.

\subsubsection{High Alumina-Silicate Glasses}

The major advantages of high alumina silicate waste glasses are the excellent chemical, thermal, and mechanical durability due to the high silica and alumina content. The disadvantages are the high melting temperatures of $>1350)^{\circ} \mathrm{C}$, which require a higher temperature processing environment and may lead to higher volatilization of hazardous species and, therefore, limited retention of these wastes in the glass (see Referenee 22). Melt corrosivity of the high alumina silicate glass is comparable to that of the commercial Pyrex glass and is greater than the borosilicate glasses due to a higher fabrication temperature. An evaluation of process conditions for the high alumina silicate glasses indicates that while they have superior product characteristics than BSG, they are more difficult to process.

\subsubsection{Iron-Enriched Basalt (IEB)}

Another class of the aluminosilicate glass-ceramic which is considered for nuclear waste immobilization is the iron aluminosilicate, an analogue to natural basaltic rock. Of particular interest are silicate melts relatively low in alkalli melals, i.e., $<10 \% \mathrm{R}_{2} \mathrm{O}$ where $\mathrm{R}$ is $\mathrm{Na}$ or $\mathrm{K}$. The foremost objective is to immobilize heavy metals within a stable iron aluminosilicate matrix. A slag composition with particular promise for fixing heavy metals is $\mathrm{SiO}_{2}-\mathrm{Al}_{2} \mathrm{O}_{3}-\mathrm{FeO}_{\mathrm{x}}-\mathrm{MO}$, e.g., an iron-enriched basalt investigated at Corning Glass Works ${ }^{27}$ and the INEL. ${ }^{28} \mathrm{M}$ is either an alkaline metal, an alkaline carth, or a combination of the two groups. Properly formulated and processed, this slag resists chemical and physical decomposition. In geological terms, basalt is an igneous crystalline rock, a slag formed in nature from mixtures of oxides. Basaltic magma, cooled slowly, formed crystalline phases rather than amorphous phases. Two major components are plagioclase feldspar and monoclinic pyroxene. The ratios of $\mathrm{FeO} / \mathrm{Fe}_{2} \mathrm{O}_{3}$ (or $\mathrm{Fe}^{2+} / \mathrm{Fe}^{3+}$ cations) apparently are optimal between $0.1-0.5$ (see Reference 27) in terms of avoiding undesirable foaming and precipitation of metallic species ciuring processing.

$A$ basalt contains a relatively high amount of $\mathrm{SiO}_{2}, \mathrm{Al}_{2} \mathrm{O}_{3}$, and $\mathrm{Fe}_{2} \mathrm{O}_{3}$. These higher valency cations can exchange for other heavy metal ions with comparable ionic sizes and valency. The pyroxene incorporates greater concentrations of the oxides, such as $\mathrm{CaO}, \mathrm{MgO}$, FeO, which can exchange for other heavy metal ions with comparable ionic sizes and valency. In terms of melt composition formulation fior metal incorporation, Table 3-5 (sec Reference 27) shows the ionic size 
Table 3-5. Cation size indices and valency for ionic exchange reaction (see Reference 27).

\begin{tabular}{cccccc}
\hline $\mathrm{K}(\mathrm{I})$ & 0.03 & $\mathrm{Fe}(\mathrm{II})$ & 0.14 & $\mathrm{Fe}(\mathrm{III})$ & 0.22 \\
$\mathrm{Na}(\mathrm{I})$ & 0.06 & $\mathrm{Cu}(\mathrm{II})$ & 0.14 & $\mathrm{Mo}(\mathrm{IV})$ & $0.2 \mathrm{~S}$ \\
$\mathrm{Ba}(\mathrm{II})$ & 0.07 & $\mathrm{Ni}(\mathrm{II})$ & 0.14 & $\mathrm{Ti}(\mathrm{IV})$ & 0.28 \\
$\mathrm{~Pb}(\mathrm{II})$ & 0.08 & $\mathrm{Mg}(\mathrm{II})$ & 0.14 & $\mathrm{AL}(\mathrm{III})$ & 0.35 \\
$\mathrm{Ca}(\mathrm{II})$ & 0.09 & $\mathrm{U}(\mathrm{IV})$ & 0.19 & $\mathrm{Si}(\mathrm{IV})$ & 0.48 \\
$\mathrm{Mn}(\mathrm{II})$ & 0.13 & $\mathrm{Zr}(\mathrm{IV})$ & 0.20 & $\mathrm{As}(\mathrm{V})$ & 0.60 \\
$\mathrm{Zn}(\mathrm{II})$ & 0.14 & $\mathrm{Cr}(\mathrm{III})$ & 0.22 & $\mathrm{P}(\mathrm{V})$ & 0.62 \\
\hline
\end{tabular}


indices and valency for exchange reactions. The Roman numerals in the parenthesis are the oxidation states of the metal ions.

Thus, $\mathrm{Zn}(\mathrm{II}), \mathrm{Cu}(\mathrm{II})$, and $\mathrm{Ni}(\mathrm{II})$ tend to substitute for $\mathrm{Fe}(\mathrm{II})$ and $\mathrm{Mg}$ (II), and $\mathrm{Cr}$ (III) $\mathrm{lo}$ substitute for $\mathrm{Fe}$ (III) in a crystal lattice. In feldspar and pyroxene, the alkali metals are acceptors for $\mathrm{Ba}$ (II) and $\mathrm{Pb}$ (II); also the alkali earth ions and $\mathrm{Fe}$ (II) are aceeptors for all other ions with similar size and charges. The silicate melt should contain a wide range of higher valency oxides such as $\mathrm{Zr}(\mathrm{IV}), \mathrm{Ti}(\mathrm{IV}), \mathrm{Al}(\mathrm{III})$, and $\mathrm{Si}(\mathrm{IV})$ to aceept the various heavy metals in the feedstock. Excessive addition of sodium and calcium oxides to an alumino-silicate is known to result in more rapid weathering of the silicate matrix. Incorporating a reasonable or controlled portion of the $\mathrm{Na}(\mathrm{I}), \mathrm{K}(\mathrm{I})$, $\mathrm{Ca}(\mathrm{II}), \mathrm{Fe}$ (II), and $\mathrm{Mg}$ (II) ions with the silicate can actually enhance the environmental compatibility by providing the substitutional or interstitial sites for other hazardous metal ions. There can also be important process benefits; increasing the aluminosilicate alkaline or alkaline earth metals content typically lowers both its viscosity and in some cases the liquids temperature. As a result, slag mixing and uniformity in the melter operation can be improved, which can be important for producing homogeneous and environmentally stable slag.

One INEL study of IEB (sec Relerence 28) for nuckear waste incerporation found IEB had high capability to incorporate radioactive nuclei and other toxic metals. Figure 3-2 shows the results of the INEL'S IEB studies. IEB can dissolve up 1014 wl\% of zirconia, which in turn has high solubility for $\mathrm{UO}_{2}$. When uranium dissolves and oxidizes in the IEB melt, it forms extensive stable solid solutions with $\mathrm{ZrO}_{2}$ in the IEB malrix.

\subsubsection{Glass-Ceramics}

Although glass-ceramics have also been examined as hosts for the solidification of nuclear waste, these forms proved more diflicult to process and are not as flexible toward variations in

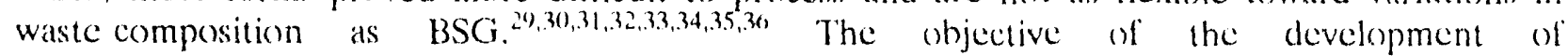
glass-ceramies was to provide chemical, thermal, and mechanical stability superior to the boresilicate glasses. However, intergranular glassy phases often formed in the ceramic materiats, especially when alkali-containing waste was processed. This intergranular glass limited the product stability and durability. ${ }^{37,38}$ The chemical durability of glass-ceramics was found to be comparable to BSG. ${ }^{39}$ The enneept of using a glass-ceramics matrix for the immobilization of the radioactive waste is accomplished by tailoring the dissolution of the waste in an assemblage of mineral phases. ${ }^{40}$ In the glass-ceramic formulation, the idea is to use additives to alter the waste composition, thus tailoring the wastes chemically so that the desired hosis for the radionuclides are produced after solidilication. This class of synthetic materials includes the silicate-titanates and silicate-phosphate glass-ceramics.

\subsubsection{Phosphate Glasses}

The effort and intensity in the research and development of phosphate-based waste glass for radionuclide immobilization was completely dwarled by the development of boresilicate glasses. The. relatively lack of major development in phosphate glasses has been attributed to the lack of industrial usage of these types of glasses and hene the lack of commercial experience and technology such as exists for the various silica-based glasses. The altractive low melting temperature of the phosphate glasses is offset by the corrosivity of the melt to the melter system and the ease with which the glass is devitrified (see Reference 25). Phosphate glasses were also attractive because Mo and $\mathrm{SO}_{4}{ }^{2}$ were more soluble than in borosilicate glasses (see Reference 36). Compared to borosilicate glasses the phosphate glasses have severe shortcomings. In a demonstration project in 1966 , PNL revealed the foilowing sionteomings of the phosphate glass investigated by PNL (sce Reference 20) as follows: 


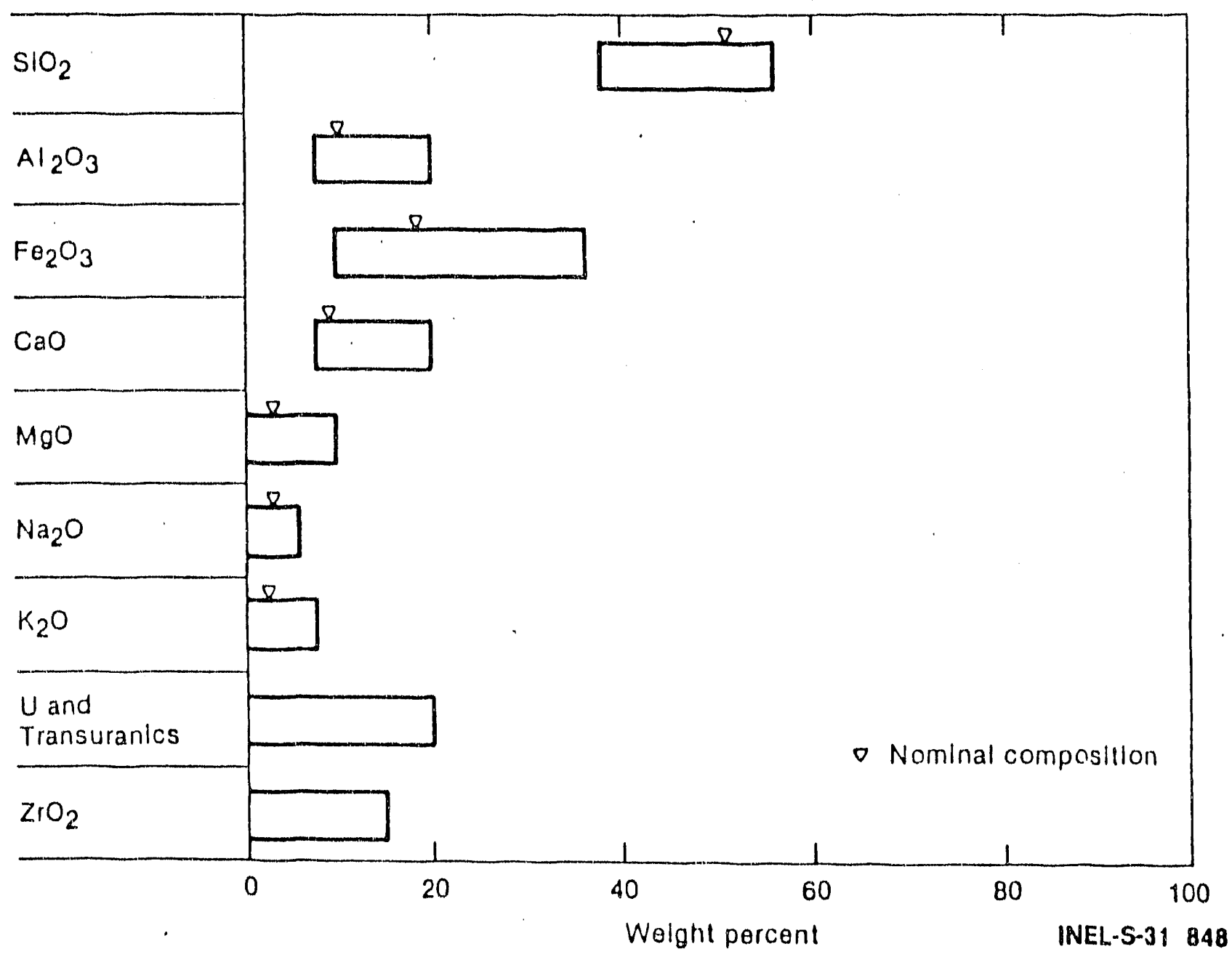

Figure 3-2. Tolerance range of major oxides in IEB. 
- High volatility of Ru during processing

- Excessive $\mathrm{Fe}(\mathrm{III})$ and $\mathrm{Na}(\mathrm{I})$ required to adjust the melting point and the mell viscosity

- Extreme corrosivity of the melt - requiring Pt melters and limiting the pouring temperature of the melt into metal canisters

- Low solubility of ertain waste components $-\mathrm{Al}_{2} \mathrm{O}_{3}$, alkaline earth oxides, and TRUs

- Segregation of fission products in the glass - increased leaching

- Rapid thermal devitrification at temperatures $>5())^{\circ} \mathrm{C}$ - increasing the risk of leaching by a factor of 1000 .

Later, in 1984 lead-iron-phosphate glass wats developed as a new, very stable and casily prepared glass for the immobilization of all types of high-level liquid wastes. ${ }^{41.42}$ The corrosion rate of this new glass is at least $1(k)$ - $I(K)($ ) times lower than the corrosion rate of a comparable borosilicate waste glass at $900-100\left(0^{\circ} \mathrm{C}\right.$. In addition, the glass could be prepared at temperatures as low as $8000^{\circ} \mathrm{C}$ because of low melt viseosity. Furthermore, the glasses were not adversely affected by large doses of gamma radiation in water at $135^{\circ} \mathrm{C}$. It was suggested that the improved chemical and thermal stability was caused by the content and structural role of $\mathrm{Fe}(\mathrm{III})$ which strengthened the cross bonding of the phosphate chains in the glass. ${ }^{43}$ However, melt corrosivity and incompatibility with certain canister materials ${ }^{44,45}$ were observed for this new glass. Even with this new glass formulation, the shortcomings in low waste solubility and rapid devitrification (poor thermal stability) at temperatures above $550^{\circ} \mathrm{C}$ still persisted. By and large the rescarch and development work on phosphate glasses has been abandoned.

\subsubsection{Synroc}

Synroc ${ }^{46}$ is a synthetic three-phase crystalline titanate, designed on the basis of known geochemistry, for the immobilization of HLW to higher levels of assurance over a wider range of geological disposal temperatures than those applicable to BSG. The three principal phases, $\mathrm{BaAl}_{2} \mathrm{Ti}_{6} \mathrm{O}_{16}$ (barium hollandite), $\mathrm{CaZrTi}_{2} \mathrm{O}_{7}$ (zirconolite), and $\mathrm{CaTiO}_{3}$ (perovskite) can incorporate $10-20 \mathrm{wt} \%$ of all components of the HLW into solid solution. The typical weight proportions of these three phases are approximately 40,35 , and $25 \%$, respectively. A minor $\mathrm{TiO}_{2}$ phase is normally present to buffer the system and maintain the hollandite when significant amounts of Ti(III) are produced during fabrication. Synroc is very leach resistant up 10.30()$^{\circ} \mathrm{C}$ and it will allow consolidated HLW to be dispesed without engineced storage, thus increasing public acceptability for final waste form disposal. The fabrication of Synroe is very different from other final waste form processes because it does not go through a melting process. The process requires the mixing and calcining of HLW (composition well controlled) with fixed amounts of $\mathrm{TiO}_{2}, \mathrm{ZrO}_{2}, \mathrm{Al}_{2} \mathrm{O}_{3}, \mathrm{BaO}$, and $\mathrm{CaO}$. The calcined products are then consolidated by hot-pressing 16 a high density final waste form at a cemperature well below the melling temperature under reducing conditions.

\subsubsection{Recommendations}

A preliminary survey on nuclear waste glass form: has been completed. Not enough details on each process were given. More in-depth comparison of the advantages and disadvantages of borosilicate glasses, high aluminat silicate glasses, glass-ceramics, and iron-enriched basalt should be 
done. Both the INEL TRUW and INEL-contaminated soil fall within the range of IEB compositions. Naturally, IEB should be the preferred choice for the final waste form for incorporation of the INEL nuclear wastes. IEB formulations have comparable or better performance characteristics for waste incorporation and retention than the boresilicates glasses. The addition of zirconia to the IEB needs further studies since the formation of zirconia-urania solid solutions will enhance the retention of $U$ and/or TRUs in the waste form. The addition of titania-zirconia to the IEB has the polential of forming major Synroc-like phases in the IEB. These phases will enhanee the incorporation and retention of TRUs in the modified $1 E B$ waste form. The volatilization of LL and TRU radionuclides from a high temperature melier has not been established. The rare carths (or lanthanides) are good surrogates for uranium and plutonium in establishing the dissolution behavior in the slag and the volatilization from the slag. These areas will need bench studies.

\subsection{Criteria for RWMC TRU Final Waste Form}

\subsubsection{System Design Study Generalized Criteria}

There are several Comprehensive Environmental Response, Compensation, and Liability Act (CERCLA) criteria which guided the System Design Study to set the top-level requirements for the linal waste form performane characteristics. The CERCLA criteria included the following.

- Overall protection of human health and the environment

- Compliance with appropriate or relevant and applicable requirements

- Long-term effectiveness and permanence

- Reduction of toxicity, mobility, and volume through treatment

- Short-term effectiveness

- Implementability

- Cost

- State acceptance

- Community acceptance.

\subsubsection{Desirable Final Waste Form Characteristics and Criteria}

Based on the CERCLA criteria, the preliminary SDS identilied that the preferred final waste form for TRU waste is a leach-resistant, high-integrity, synthetic glass or rock which can capture TRU waste clements and can meet the general requirements established for a high-level waste to be disposed of in deep geological repository. The final waste form must also eomply with the transportation and packaging (TRAMPAC) requirements. The high-integrity final waste form must possess the following desirable properties performance characteristics:

- Chemical stability in high leach resistance

- Thermal stability

- Mechanical durability in high impact resistance to generate breathable lines

- Macroscopic homogeneity for overall final waste form performance

- Least volume

- High stability to internal $\alpha, \beta$ and $\gamma$ radiation damage.

From the desirable product properties performance characteristics, a set of specific performance criteria has been generated for the RWMC TRU final waste form. The final waste form performance criteria include the following: 
- Plutonium and other TRUs will be dissolved, oxidized, and chemically incorporated into the slag to form a high integrity final waste form which is equivalent to or exceeds the expectation for BSG for the HLW.

- Low level wastes and/or fission products will be dissolved, oxidized, and chemically or physically incorporated into the slag to form a high integrity final waste form which is equivalent to or excecds the expectation of BSG for the LLW.

- HVPM will be either dissolved/oxidized and chemically/physically incorporated into the slag by appropriate methods, or volatilized from the melier and collected down-stream of the melter unit for separate disposal.

- The final waste form should enable a high concentration of Fe and $\mathrm{Al}$ to be chemically dissoived because they are the major components of the INEL TRU waste stream and this would yield maximum volume reduction.

- The final waste form will not contain residue organic materials.

- Potential for gas generation will be nonexistent because there is neither organic residue nor water of hydration in the vitreous/ecramic final waste form which is produced from very high temperatures processing $\left.(\text { e.g., }>15())^{\circ} \mathrm{C}\right)$.

\subsection{Final Waste Form Evaluation}

\subsubsection{Materials Characterization Methods}

Ex situ thermal processing technology is being eonsidered to treat the soil contaminated with hazardous and radioactive wastes at high temperatures and lix the contaminants in a benign high quality glass or glass-ceramic linal waste form. The process involves heating the contaminated soil and wastes with appropriate additives in a high temperature processor to produce a molten slag. Natural convective currents within the melt help to homogenize the stabilized materials. The molten slag cools to a benign and high integrity glass or glass-ceramic final waste form, depending on the cooling rates, chemically and physically resembling natural obsidian or other volcanic rocks. The final waste form can be cast either as monoliths, or as water granulated marbles, or frits. Since the primary purpose of the ex situ thermal treatment process is to stabilize and immobilize nuclear and toxic waste components, the chemical eomposition and the release characteristics of the final waste forms must be known to determine an accurate performance assessment of the process. Failure to fully characterize the final waste forms from bench, pilot, and field demonstration tests would undermine the credibility of the ex situ thermal treatment process as a method for the INEL environmental restoration program.

Currently, there is a substantial data base on the chemical, physical, and internal radiation damage ${ }^{47,48}$ stability properties of different final waste forms which includes glass, glass-ceramic, and Synroc (sec References 13,46, 48). ${ }^{49,50}$ However, the final waste forms are directly related 10 the eomposition of the incoming waste to be treated and the host matrix, the thermal history of materials during reaction, and phases and morphology development during vitrilication or devitrilication of the melt. Since the INEL soil and waste stream compositions are varied and unique, detailed characterization procedures to qualify the final wiste for disposal are required. 
The waste forms produced during laboratory, bench, and pilot facility tests will be made using surrogate wastes. Some laboratory, bench, and pilot lests will be conducted using radioactive and mixed wastes. The field demonstration will process the actual mixed radioactive hazardous wastes. When radioactive waste forms are produced, internal radiation effects, along with the other standard tests, will be performed. The data generated will be used to determine how well the ex situ high temperature melting process satislies CERCLA criteria.

Evaluation of the final waste form performance characteristics will determine the extent $f(1$ which the CERCLA criteria are met. Characterization of the final waste forms can be divided into three aspects: (a) sampling and bulk characterization. (b) chemical, phase, and morphological analyses, and (c) stability or durability tests. Testing details of the latter two aspects of materials characterization are contained in Appendix B.

\subsubsection{Sampling and Bulk Characterization}

The primary objective of the produce evaluation statistical sampling activities of the bench, pilot, and field demonstration tests are to provide an accurate description of the bulk final waste form and detailed evaluation of the properties of the different phases observed. For the cast monoliths, sampling will be conducted using cores drilled through the monoliths or through a fracture of the monolith. A megascopic physical description of the monolith is the first step in the characterization of that material. The physical description provides the most general information gained during the material characierization processes. A megascopic deseription of the monolith is important because the sampling strategy of all other characterization techniques eannot be detailed until the type and distribution of the megascopie regions are known. By identilying the major regions of the monoliths by the unaided eye, and stratified random sampling those regions, sufficient data can be generated 10 determine the chemical, morphulogical, and durability properties of each region. A megascopic evaluation will also reveal the volume pereent of the total that each region represents. This information is required to allow for a bulk mass balance, an indication of potential interfacial reactions, and a determination of the bulk durability.

\subsubsection{Chemical, Phase, and Morphological Analyses}

The purpose of chemical analysis is to determine the elemental composition of the final waste form as a whole, by regions, and by the phases in each region. The purpose of phase and morphological andyses is to identify the crystallographic phases of the bulk and in the regions. The molten slag is a complex elemental system which ean form multiple phases while solidifying. During casting of the monolith, different regions of the cast have different cooling rates and this is reflected hy the formation of heterogeneous phases in the monolith. Fast cooling outer regions of the monolithic bulk will vitrify 10 form glasses while the slow cooling inner regions will solidify into crystalline phases. Due to thermal dilfusion effect, some glasses in the intermediate regions will partially devitrify to enstalline matcrials. The structure and elemental eomposition of each region will reveal if any waste components have segregated into less durable phases or migrated into interfaces hetween regions or the grain boundaries of erystalline phases.

\subsubsection{Chemical Durability}

Chemical durability lesting hat been discussed by Bates ${ }^{51}$ regarding in situ vitrification of NEL huried waste. The discussion can be directly applied to the evaluation of the final waste form trom a melter since these final waske forms are very similar There are currently no specifo durability specilications estathlished for ISV IEB final waste forns. The minimum expected testing requirements 
will be those currently established for landfill disposal. Since September 1990, the EPA toxicity characterization leaching procedure (TCLP) ${ }^{52}$ has replaced the Extraction Procedure Toxicity Test (EPTOx). Passing the test only classifies the ISV/IEB waste final form as satisfying the RCRA criteria for EPA-designated toxic metals leach characteristics. However, the TCLP lest procedures neither address the radioactive components, provide an assessment for the long-term durability, nor make a comparison to other highly durable linal waste forms or natural analogs. For each type of the durability tests, all major phases within the ISV/IEB final waste form should be lested, if possible. Where multiple phases cannot be separated, such as when devitrification produces an intimate mixture of different small grain erystalline phases, these multiphase mixtures should be lested as a single phase.

Assessing the long-term durability of the ISV/IEB linal waste form is difficult because it requires extrapolation of data from short-term tests to geologic time frames. One method to assess the long-term durability performance is to compare the ISV/IEB waste form to the natural analogs. A number of the natural analogs are similar in composition and morphology to the ISV/IEB final waste forms. These include obsidian, basalt, tektites, and andesites (all of which are millions of years old). The relative durability of many natural and ancient man made glasses have been shown to brack t the durability of waste glasses. ${ }^{53,54,55,56}$ Thus, relating the behavior of the ISV/IFEB linal waste forms determined from short-term leach tests to the observed behavior of natural anaings provides an exeellent means of validating the long-term stability of the ISV/IEB final waste forms. The natural analog also provides a basis for assisting in public acceptance of the ex situ high cemperature processes for the INEL environmental remediation program. While the public has litte understanding about the durability of the high-level waste glasses, they will have an appreciation for a comparison made of ISV/IEB final waste forms to a "rock" they can pick up in the field that has been exposed to the environment for millions of years.

\subsubsection{Physical Durability}

The physical durability of the final waste form will be evaluated using a variety of mechanical test methods. The Impact Test reveals the resistance of the monolith during impact to generate breathable fines and is necessary to satisly TRAMPAC requirements, The Bending Test reveals the fracture toughness of the final waste form. Indentation Tests indicate the hardness of the final waste form. Splitting Tensile Strength Tests give the maximum strength of the final waste form.

\subsubsection{Radiation Durability}

The radiation damage has long-ferm eflects on the mallerials properties. The chief sources of radiation in the linal waste forms are the $\beta / \gamma$ decay of fission products (e.g. Cs-137 and Sr-9)1) and the $\alpha$ decay of the actinides. $\beta / \gamma$ decaly of fission products is responsible for the bubble formation (see Reference 49) and the heat generation early in the history of the final waste form. The $\alpha$ decaly of the actinides remains importint through out the history of the final waste form. The $\beta$ decay and $\alpha$ decay events can cause three lypes of radiation damage in the linal waste form (sec Reference 48 ): (a) collision eascades which cause atomic displacements and the creation of Frenkel defect patirs due (1) elastic collisions betucen nuckear particles (c.g., $\alpha-\alpha$ or $\alpha$-recoil nuckei), (b) ionization effects ansociated with high velocity $\alpha$ or $\beta$ pantickes, and $(c)$ the transmutation of radionative paren nucke into different elements. Of ihese thee dfects, the atcmic displacement is the most important precess which causes atomic-scate rearrangemen of the structule and hence ketds to the greatest change in chemical and phesical durahilitics of the final watste forms. Becouse the mass difference helucen an

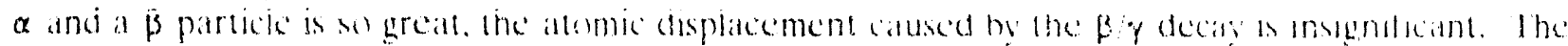
Simulated Radiation Damage Test prosides the comparative resisto ses of the amorphorous and the 
crystalline phases in the final waste form to atomic displacement and ionization damage due to internal radiation source effects.

\subsubsection{Proposed Waste Form Characterization Methods for Tests}

Table 3-6 summarizes the available test methods lor chemical, irradiation, and mechanical durability evaluation of the final waste forms. It is useful to group the waste form characterization into a short-term and a long-range focus. The focuses are needed to compile data to qualify the final waste forms to satisfy the CERCLA criteria.

The short-term focus is to characterize the properties of the final waste forms produced from the bench studies and the pilot tests based on the process parameters. The results will become a data base for critical evaluation of the ex situ high temperature thermal process and its ability to produce aceeptable high integrity final waste forms. The data base will also provide a basis to qualify the final waste form for the CERCLA criteria. The characterization methods recommended for the short-term focus are the following:

- TCLP-required for EPA designated toxic metals

- MCC-3-agitated leach test of powders for all metals, particularly for radionuclides

- ICP

- SEM - EDXS/WDXS - x-ray Maps

- $\mathrm{OM}$

- $\quad$ XRD

- Irradiation tests

- Indentation - hardness fest

- Bending - fracture toughness test.

The long-term focus is to characterize the propertics of the waste forms from the demonstration tests based on the production parameters determined from the pilot tests. The results will become a data base for critical evaluation to qualify the final waste forms to satisfy the CERCLA and TRAMPAC criteria for permanent dispositions. The long-term fous will include the MCC-1 and impact tests in addition to all the short-term materials characterization methods as follows:

- Impact test-required to qualify the final waste form for TRAMPAC criteria

- MCC-long term static leach test of monoliths for all metals, particularly for radionuclides.

Splitting tensile tests will not be recommended for the evaluation of the strength of the final waste form for either the short-term or the long-term focus because this method is very sensitive to the surface micre crack conditions. 
Table 3-6. Summary table of chemical, irradiation, and mechanical durability tests for the final waste forms.

\begin{tabular}{ll}
\hline Test Method & \multicolumn{1}{c}{ Functions } \\
\hline TCLP & EPA regulatory leach test for designated toxic metals \\
MCC-1 & Static leach test for monoliths, reveal leach resistance \\
MCC-3 & Agitated leach test for powders, reveal leach resistance \\
Forward Rate & Evaluate and predict the dissolution hethavior of waste forms \\
Irradiation & Predict waste form resistance to internal radiation damage \\
Bending & Determine fracture toughness of the final waste form \\
Impact & Determine resistance to generate breathable lines, satisfy the TRAMPAC \\
& criteria \\
Indentation & Determine hardness for the final waste form \\
Tensile & Determine maximum strength of the final waste form
\end{tabular}




\section{WASTE STREAM PROCESSING}

\subsection{Introduction}

Processing considerations are presented for both an overall systems design (see Section 4.2) and a more detailed materials processing (see Section 4.3) viewpoint. The input waste stream considerations are taken from Section 2 and the desirable waste form microstructure and composition from Section 3. The systems design is based on the Preliminary Systems Design Study (SDS) (see Reference 1) as modified by materials processing needs and focuses on requirements for processing major constituents. The detailed materials processing focuses on problem materials and how to control and bind them in a suitable waste form. The Systems Design Study has been extremely valuable by providing a relatively detailed technical assessment of options and estimated costs of the types of process components, subsystems, and overall systems that could be used to generate suitable waste forms.

This chapter takes the analysis for the "incinerator/melter option" one step further by considering more specific input waste stream compositions and process methods required to get a desirable waste form. In the following, the difference between "waste" and "waste soil" needs to be recognized because the buried waste is often separated into waste streams and soil streams (which also contain waste, e.g., TRU-contaminated waste vs TRU-contaminated soil). The topics to be discussed in this chapter are various preliminary systems design component scenarios, appropriate melting processes of interest in the melter or other components, and problem areas in which more information (R\&D) is needed to complete the desired design.

\subsection{Systems Design Scenarios}

\subsubsection{General Considerations}

Five general systems design scenarios are considered, each of which has several suboptions. The scenarios are modifications of the SDS recommended melting and incineration system with postsort (2-EB-4) for which the process diagram is shown in Figure A-2. The first scenario is essentially identical to the SDS system and represents the base case for comparison. The variations in the systems and options are summarized in Table 4-1. The first four columns are SDS subsystems for retrieval, soils processing, LLW processing, and metals decontamination.

The SDS Retrieval Subsystem (S-BE-4) is composed of two moving buildings 127 by 250 fit long each with space for equipment storage, scooping the earth, conveying, opening the containers, depositing in new containers, container storage, testing, control, power, and maintenance rooms (see Figures A-3 and A-4). The sorting out of highly radiative objects, large mechanical or construction objects, or unusually large containers for special case preprocessing occurs during retrieval. Soil can be separated and routed to the SDS Soils Processing Subsystem (S-EB-2), that thermally desorbs the soil at $450^{\circ} \mathrm{F}$, separates the TRU-contaminated soil from the LL-contaminated and clean soil, assays for and separates the LL-contaminated soil from the clean soil, and solidifies (cements) the LLW (see Figures A-5 and A-6). Metals may be routed to a Metals Decontamination Subsystem (S-EG-1) that pretreats, sizes, and decontaminates primarily the surface of the metals as needed (see Figures A.9 anc A-10). If presorting of the TRUW and LLW is desired, an on-line assay following the Retrieval Subsystem can be used to separate TRUW and LLW wastes. The latter can be 


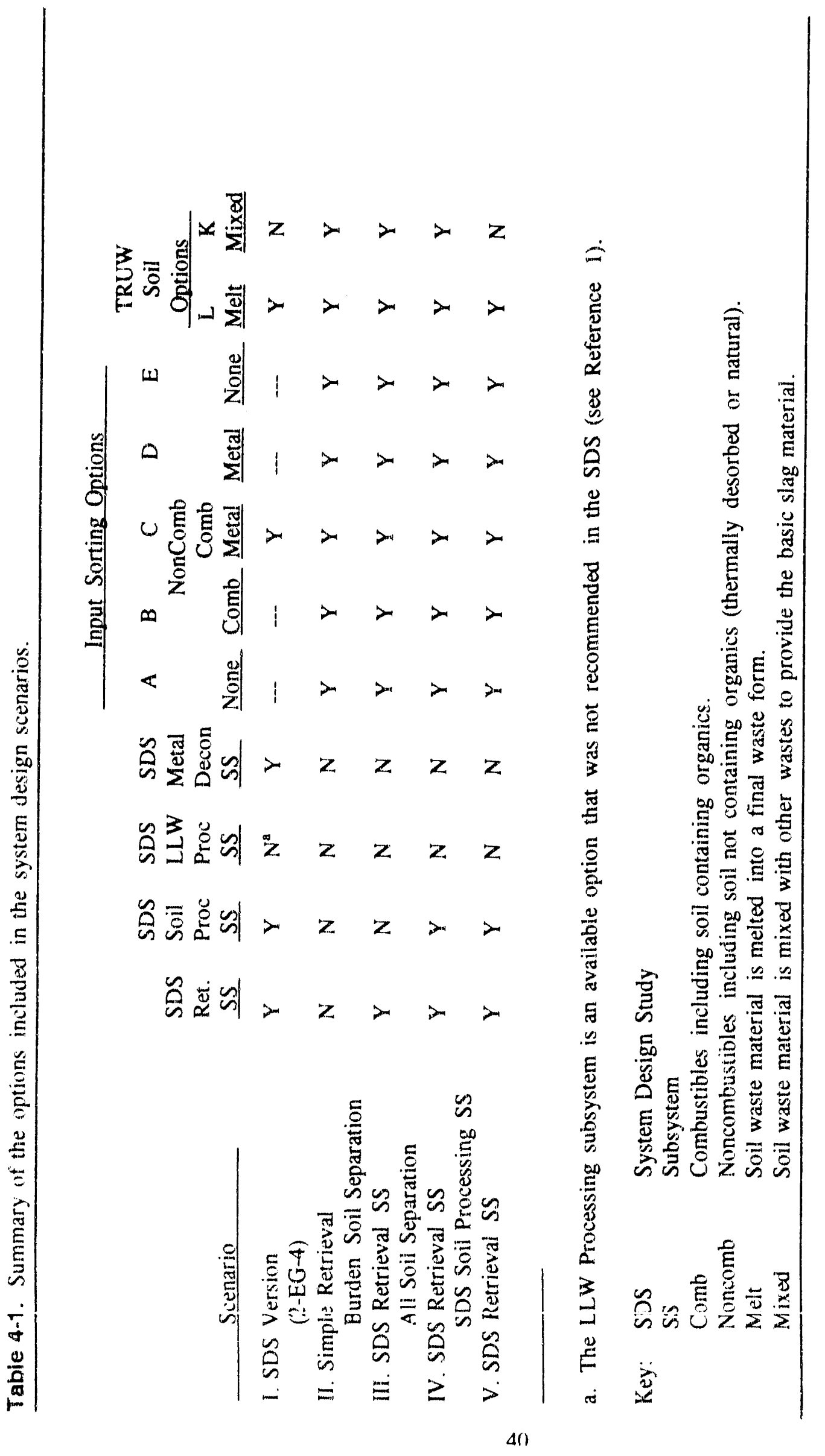


treated by the LLW Subsystem (S-IT -3), that opens packages and sorts the waste stream into metals, lead, sludge, and combustibles/loose materials which are packaged or solidified prior to assaying and disposal (see Figures A-7 and A-8).

A major question with the above is in the ability to assay TRU in objects larger than the size of pebbles or marbles. Such assaying capabilities do not presently exist with eonfidence. Many of the processes proposed are still under development (R\&D) with the resulting capabilities unknown. Other processes add materials to the waste stream which decreases the extent of volume reduction. (The Metals Decon Subsystem has $140 \mathrm{~kg}$ units out for every $100 \mathrm{~kg}$ in.) Because of this, the best scenarios of the following will include processes which are not dependent on developing new technology, but applying old technology to this new application and attempting to add as little external material as possible.

Table 4-1 also indicates the extent to which sorting options can be used in the various scenarios with sorting (A) and (E) none, (B) only combustibles, (C) noncombustibles, combustibles, and metals, or (D) only metals out from the main waste stream. It is expected that each waste stream will not exclude other stream materials, but will be predominantly the designated waste stream materials. Combustibles include containerized organies, organic-laden soils, cemented organics, and silicated organics, as well as alkali nitrates which are oxidizers. Noncombustibles (e.g., construction materials) include materials known to exclude combustibles and metals.

The reasons for separating into these waste streams will be explained in more detail in Section 4.3, but will be briefly addressed here. The combustibles are to be oxidized into $\mathrm{H}_{2} \mathrm{O}$ and $\mathrm{CO}_{2}$ with any ash, associated calcium silicate, ecment, and similar metal oxides going to the melter as part of the slag waste form. The noncombustibles can go directly to the melter as they are metal oxides already and do not have to take up space or energy in the incinerator if sorting is not inconvenient. The metals will have to be oxidized, or at least surface oxidized to remove the surface contamination of TRUW materials, which will require a melter with an oxygen atmosphere, oxygen bubbling through the melt, or equivalent. The high concentration of metals (especially aluminum) will probahly result in a higher temperature for the slag fluidity. Control of a combustion chamber with a heterogeneous fuel feed is difficult enough without compounding the problem by trying to control the composition (partitioning) within the melt/slag phase at the same time; hence, the desire to separate into different waste streams.

Other questions, of a political nature, also affect the types of processes required. In the ISV option, the input waste is vitrified in place. The TRUW and LI.W are not separated and the cost of envirenmental remediation are much smaller than when sorting and transportation are required.

The most economical and useful disposition of the soil is also desired. Is it hest to melt and package separated TRU-contaminated soil (if the soils processing subsystem is used) or to use the TRU-contaminated soil as the basic waste form to dissolve the other waste materials? The decision is a balance between polluting the nonsoil waste with TRU-contaminated soil, the decrease in volume reduction, the use of LLWW soil and probable TRU contamination. and the use/eost of processing additional vitrification material. The TRU-contaminated soil option is included in Table 4-1 as options $L$ (separate melting) and $K$ (mixed together with other waste streams). 


\subsubsection{The SDS Scenario}

The first scenario is patterned after the SDS system 2-EG-4, the Melting Incineration System With LLW Postsort (sort of TRUW from LLW after melting), which will hereafter be referred to as the SDS scenario. The identical system with presorting of the TRUW and LLW waste streams, 2-EG-1, is an alternative, but was not recommended by the SDS report because of the additional cost of the LLW processing subsystem without additional benelits in the resulting waste form. Tabie 4-1 shows that the SDS scenario includes the Retrieval Subsystem, the Soils Processing Subsystem, and the Metals Decontamination Subsystem, but excludes the LLW Subsystem in lieu of post sorting. The SDS scenario includes Option C (input sorting of combustibles. noncombustibles, and metals) and Option L (the TRU-contaminated soil is melted separately).

The flow diagram for the SDS scenario, as shown in Figure 4-1, has been modified from that in the SDS (Figure A-2) to correspond to the needs of this work and for easy comparison with alternative scenarios. The functions have been identified as Retrieval, Size Reduce/Assay, Sort/Size, Treatment, (intermediate) Assay, Post-Treatment, and Package/Disposition. The SDS scenario uses the SDS Retricval subsystem which separates the buried waste into special case, soil, and "containerized" waste streams. The Assay/Presize function consists of an on-line assay and mechanical and/or manual (remote robotic) opening of containers for sorting. (The optional LLW Presort subsystem is included as dashed lines to show how it would integrate into the system.) The Sort/Size function sorts the containerized waste stream into combustible, noncombustible, and metal streams with appropriate sizing (crusher/shrededer) operations for the next treatment stage.

In Treatment, the combustibles are incinerated with the appropriate offgas treatment. The noncombustibles go to a melter, in front of which there is a mixer to mix the waste stream with the necessary soil to make the glassy/rocky waste form, akh from the incincrator, residue from the offgas treatment, as well as any lluxes needed 10 maintain proper melter operation. The metals are routed 10 the SDS Metals Decon Subsystem from which the TRUW stream and residue goes to the melter and the LLW stream is packaged or solidified. The melter must be an oxidizing melter because of the significant input of metals and, hence, the offgas is oxidized and put into the offlgas treatment system. There is no intermediate assay or post-treatment of the final waste form planned in the SDS secenario, but these may be necessary depending on the quality of the assay methods and final waste disposal requirements. The slag waste stream from the melter is packaged, assayed for separation of TRUW from LLW, and separately packaged (TRUW) or solidified (LLW) for disposal. The disposition of reclassified LLW was not included as a separate alternative in the preliminary SDS.

Melters can, therefore, perform different functions at different temperatures and operating conditions. The characteristics of various melters discussed below are now defined. Figure 4-2 illustrates typical melters. In a neller there are two separate regions which influence operation, the gas phase above the melt and the liquid mell/slag. The melt/slag may be composed of a slag floating on top of a denser liquid metal melt. Solid metals may sink to the bottom of the melter if the melling lime and/or temperature are insufficient.

Actual melters run the spectrum from low temperature, pure Joule-heated melters (see Figure 4-2a) through transferred are heated melters with Joule, radiative and are-melt interface heating contributions (sec Figure 4-2h) up to nontransferred-arc torches for plasma-convective heating (sec Figure 4-2c). Figure 4-3 shows a cut away vicw of one of the INEL JHM used for IEB rescarch. Figure $4-4$ illustrates the difference between (a) transferred are and (b) nontransferred are

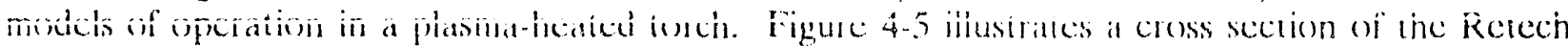
plasma centrilugal reactor (PCR) in operation at INEL/MSE in the plasma-are furnace experiment 


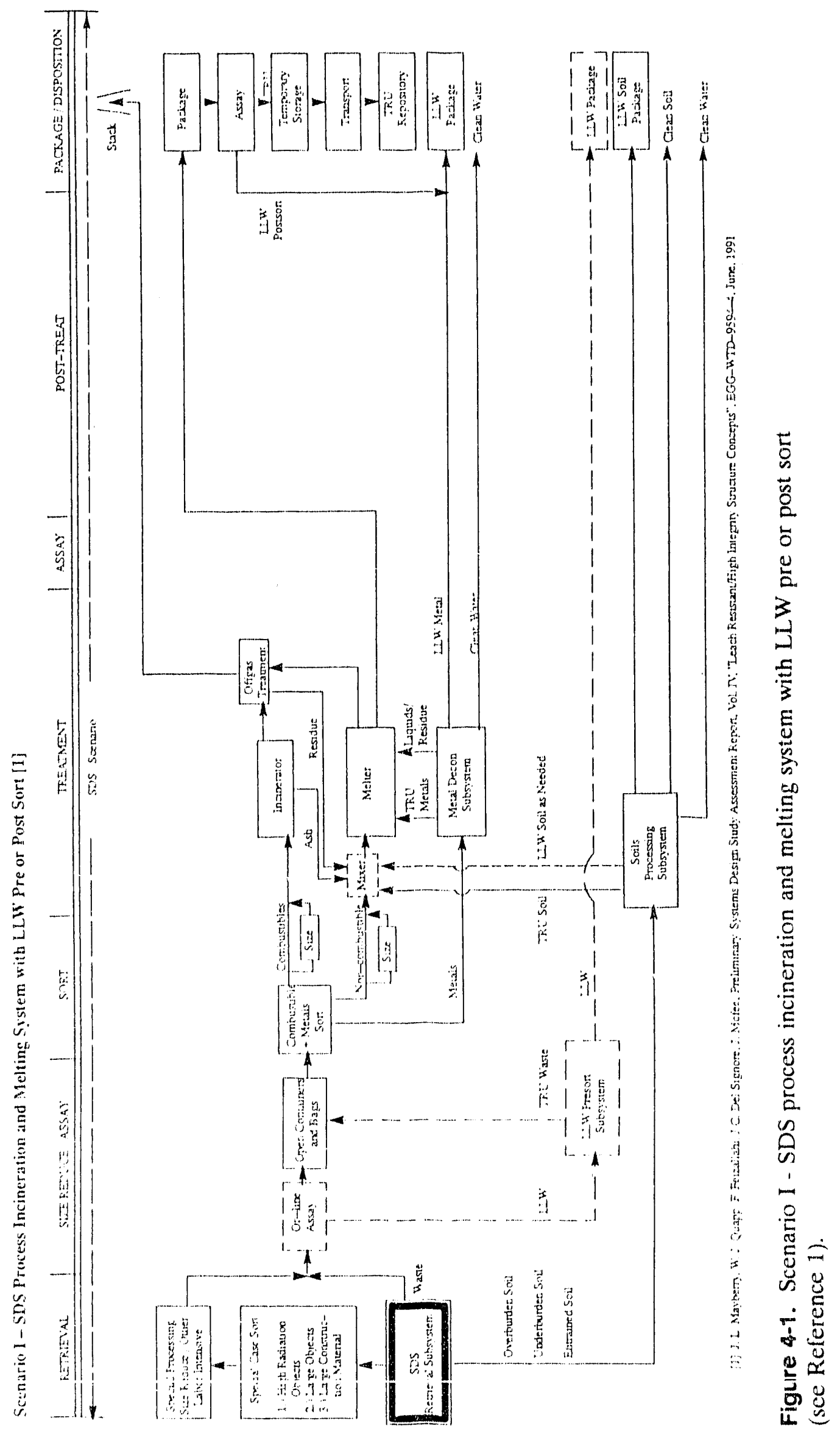




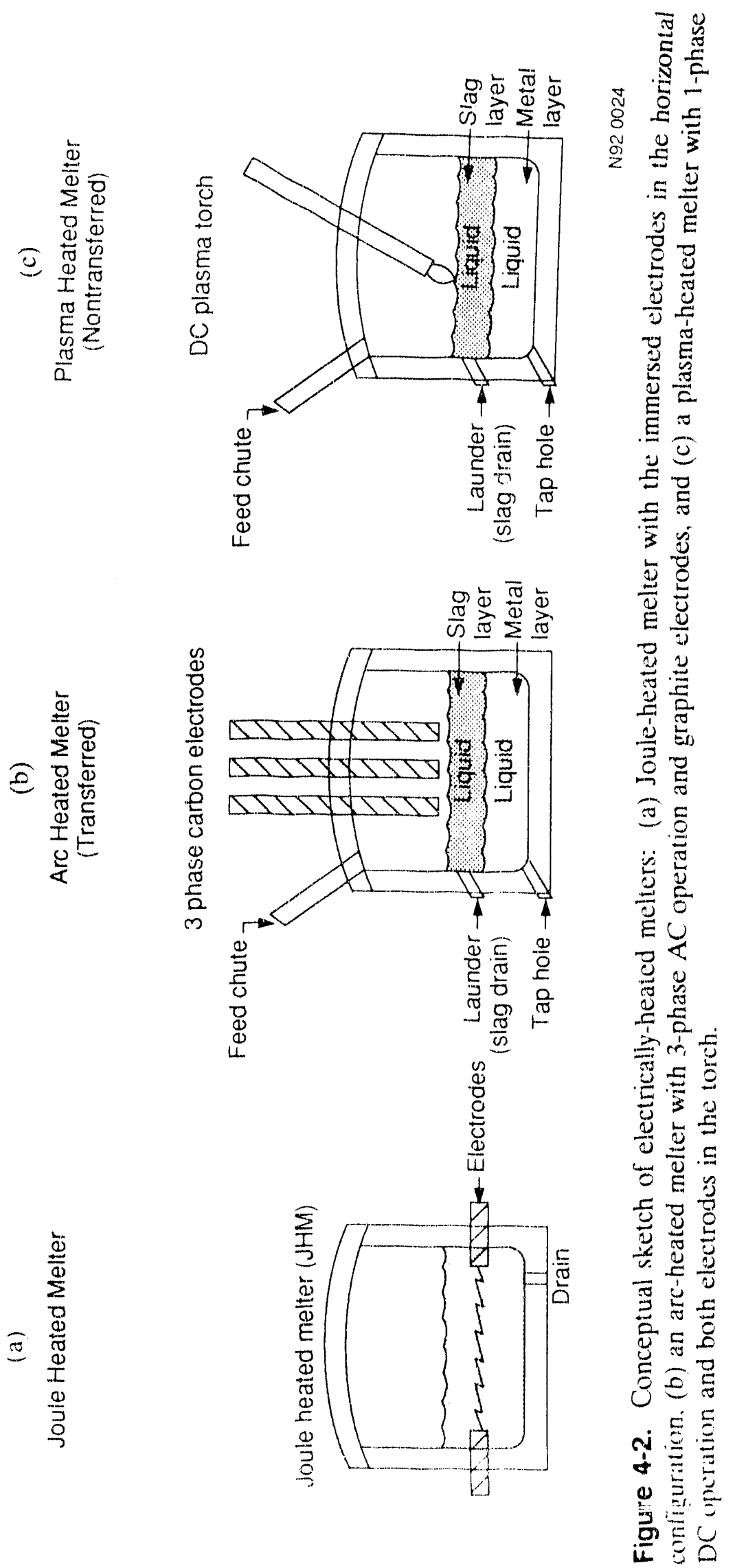




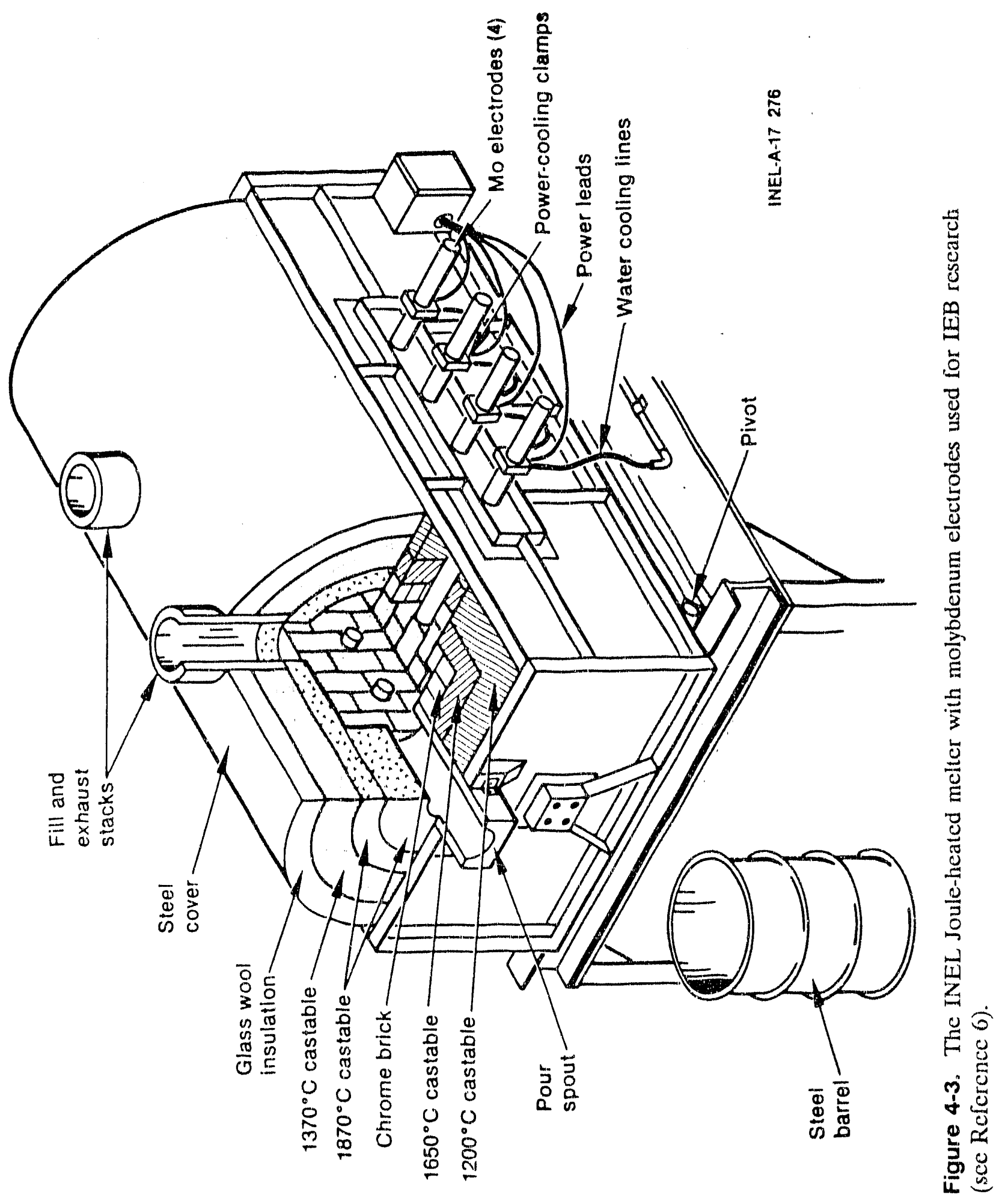


Plasma torch types

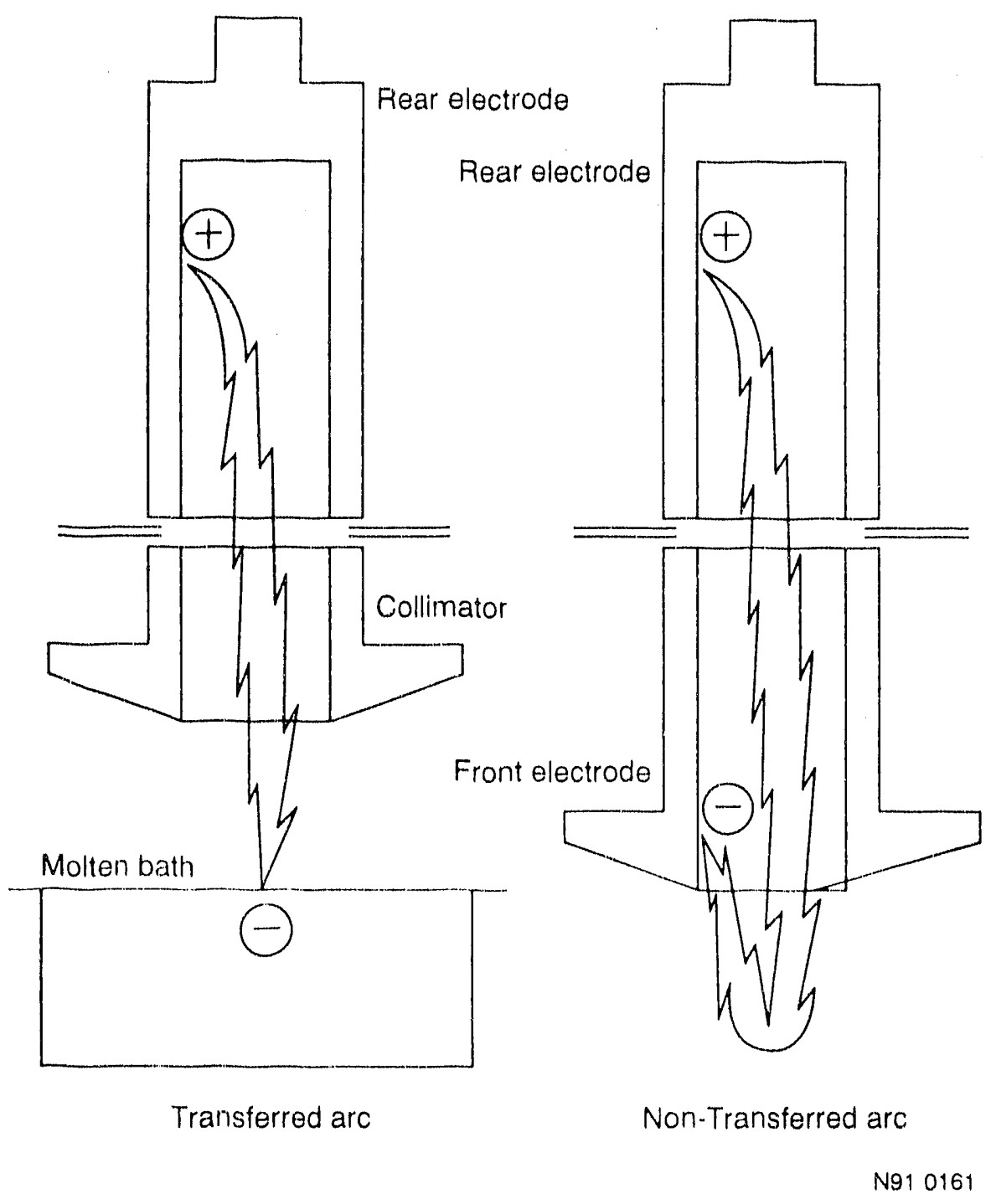

Figure 4-4. Plasma-heated melter torch-electrode configurations: (a) transferred-are torch with the melt as the cathode and (b) nontranslierred-arc torch with both electrodes in the torch. 


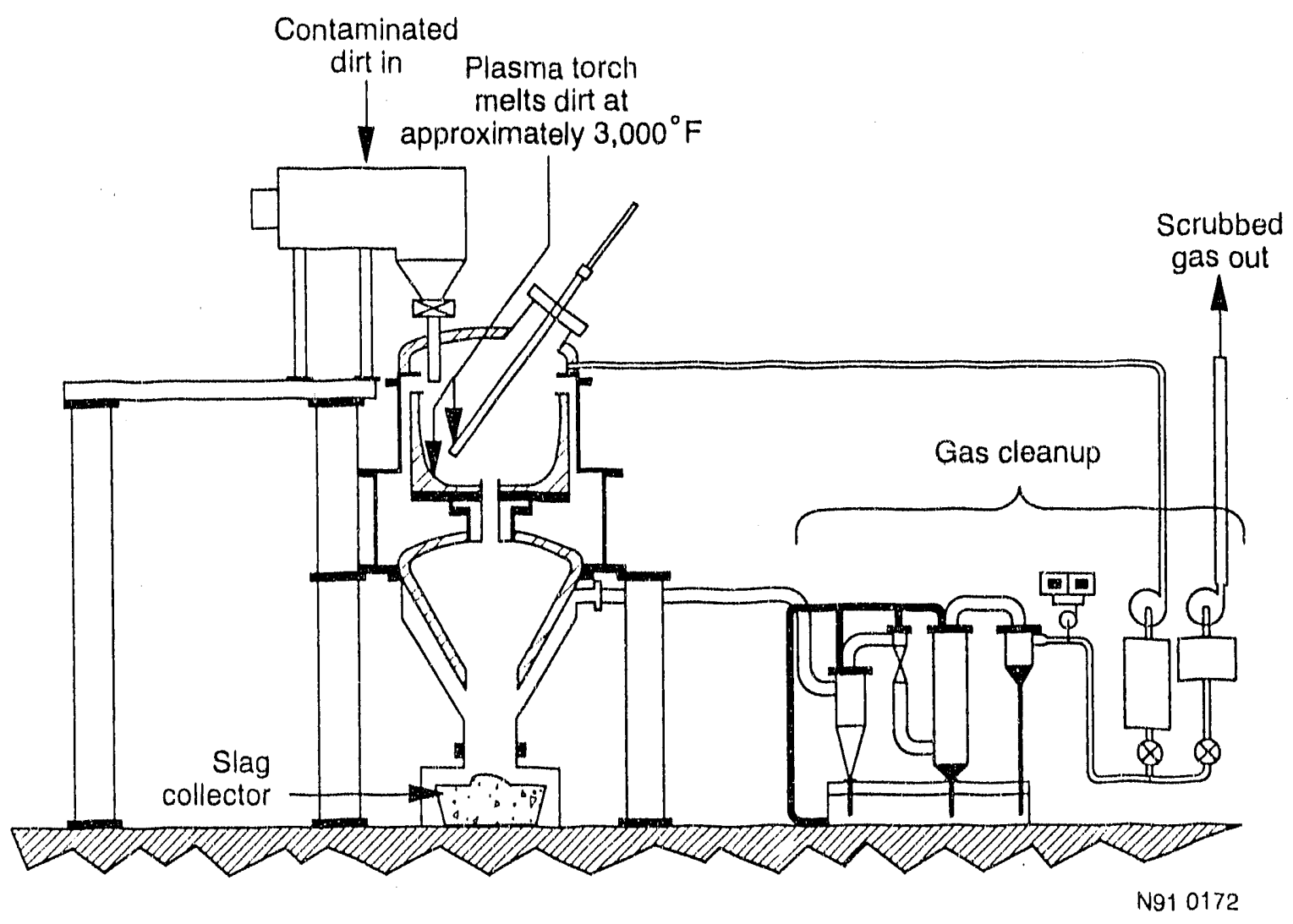

Figure 4-5. Plasma-heated melter used in the INEL PAFE experiment in the transferred-arc mode with 1-phase DC operation, metal electrode torch, an oxygen lance, and water-cooled skull with a rotating chamber that is slowed to pour the slag (see Reference 57). 
(PAFE). The PCR uses a transferred are torch with an oxygen lance for combustion inside the chamber. The slag is poured out the bottom by slowing the speed of rotation.

Low-temperature melters $(900)-120)^{\circ} \mathrm{C}$ ) can melt glasses and assimilate waste streams which are not high in metals content, especially aluminum and iron, and are not high in metal oxides or soils with high alumina (alumina-silicates, basalts) or titania/zirconia (e.g., Synroc). These melters are usually termed glass melters. Refractory-lined, Joule-heated melters with Inconel electrodes using a borosilicate glass frit for assimilation of a relatively homogeneous waste stream is one example of a low-temperature (glass) melter. Almost any melter can operate under low temperature melter conditions.

Medium-temperature melters $\left(120\left(-1500^{\circ} \mathrm{C}\right)\right.$ can usually melt various giasses, glass/ceramics and soils. A Ruby-refractory lined, Joule-heated melter with molybdenum electrodes is an example of a low-maintenance, medium-temperature melter. High-temperature melters $\left(15(x)-17(x)^{\circ} \mathrm{C}\right.$ ) are capable of melting most ceramics and metals, including iron, basaltic soils, and high temperature ceramics. Present JHM electrodes will melt or rapidly corrode under these conditions because of the locally higher temperature at the electrode.

The Joule heat source is more limited than the arc-plasma heat souree so using a skull in a JHM is marginal. The INEL attempted to employ a high-temperature JHM for IEB waste form research and found more problems than solutions (see References 2 and 58). Arc or plasma-heated melters with transferred or nontransferred (are to slag/melt) operation are capable of providing the intense heat source required without excessive electrode corrosion because the electrodes do not contact the melt or are of much higher temperature materials (e.g., graphite). The refractory corrosion problem can be overcome by using a water-cooled skull of the slag material between melt and reactor wall, while maintaining temperature with the intense heat source. Maintenance is related to graphite electrode consumption and replacement rates or to plasma torch electrode lifetimes.

The state of redox (reducing or oxidizing environment) is critical in the maintenance of some melters (as well as in obtaining optimum final waste form). Melters are designated as pyrolyzing with limited oxidation in the gas phase to vaporize and break down the organics with subsequent oxidation in an incinerator or afterburner. Oxidizing gas-phase melters are not treated explicitly, but could be substituted for combined melter and incinerator units. Oxidizing-slag melters are designed to oxidize metals in the melt/slag phase. Metal tapping melters allow the draining of liquid metal from the bottom of the metal melt, as well as slag from above it. Low-temperature JHM with Inconel electrodes work well under oxidizing or reducing conditions in the melt/slag or gas phases. A medium-temperature JHM with molybdenum electrodes will corrode rapidly under oxidizing conditions, but work satisfactorily under reducing conditions. The redox state in the gas phase of JHM does not appear to be a problem unless it influences the redox state in the melt/slag.

For arc melters, the use of graphite electrodes is no problem under reducing or neutral conditions. If the gas phase is oxidizing, the carbon will oxidize to $\mathrm{CO}_{2}$. Coating the electrode with $\mathrm{SiC}$ or a similar substance has been shown to reduce the graphite oxidation. Flooding the electrode lip with argon can reduce oxidation of the tip. If air or nitrogen is present, undesirable levels of $\mathrm{NO}_{x}$ may be obtained in the offgas. This result appears to be melter dependent as well as operation dependent. Offgas treatment of $\mathrm{NO}_{x}$ is available, but should be avoided if possible. With graphite

c. G. A. Reimann, unfinished report on a small-size JHM operation, personal communication, 1991. 
arc-melter operation, the melt/slag can be oxidizing if the oxygen getting into the gas phase is limited or its effect controlled, as above. A reducing slag is not a maintenante problem.

The allowed redox state for a plasma/arc melter with water-cooled metal electrodes can be more oxidizing than for the graphite-electrode transferred-arc melter. Both oxidizing and reducing states in either gas or melt phases are not problems. with the exception of air and $\mathrm{NO}_{\mathrm{x}}$ as discussed above. With the graphite electrodes, the are gap will probably be relatively short, with a small volume for $\mathrm{NO}_{\mathrm{x}}$ production. With a plasma nontransferred torch, the plasma gas could be blown into the melt like an air or oxygen lance. If air, the nitrogen and oxygen will be effectively bubbled through the melt, the $\mathrm{NO}_{\mathrm{x}}$ thereby quenched, and the $\mathrm{NO}_{\mathrm{x}}$ generation could be increased. $\mathrm{NO}_{\mathrm{x}}$ genera"ion is, therefore, melter dependent. The $\mathrm{NO}_{x}$ generation at the MSE PAFE project ${ }^{57}$ is less than expected considering the length of arc, the fiow rate of air, and the intensity of the plasma. The maintenance of present. plasma torch electrodes is expected to be more than on consumable graphite electrodes. The latter adds carbon to the melt which will change the Redox state and may diminish the quality of the waste form. Under chemical equilibrium, $\mathrm{SiC}$ is formed which may reduce the erosion at the refractory wall. In other plasma systems, electrode alloys have been developed to work in oxygen-rich environments (e.g., $\mathrm{TiO}_{2}$ production). The next preliminary design phase needs to resolve differences between various melter features.

Questions which have arisen during this investigation regarding the processing steps in the SDS scenario are the following. Is it relatively convenient for the SDS Retrieval Subsystem to bypass or assimilate oversize objects without delays in overall processing? The system adds even more containers and other processing materials to the waste stream which may result in a volume increase. The addition of soil or other material for generation of the glassy/rocky final waste form was not delineated explicitly in the SDS and it is not known how this was to be done. (The modification presented here uses contaminated soil.) The Metals Decontamination Subsystem adds $40 \%$ more mass to the system than it treats. The same function can be performed in an appropriate melter with negligible addition of additional mass as discussed in Section 4.3. The packaging and assay for disposal presumes that appropriate assaying of the waste form will be available to assay TRUW monoliths in a size appropriate for disposal. This does not appear to he in accord with projections for assaying capabilities in the future. Also, there is no post-treatment (e.g., controlled cooling cycle) to ensure that the final waste form has the material microstructure to provide the maximum leach resistance for toxic. TRUW, and LLW substances. This is a low-cost option to obtain the best final waste form characteristics.

Scenarios II through IV address improvements in the SDS scenario to overcome the above deficiencies. Seenario $V$ considers the option of using borosilicate glass as the vitrified waste form where possible.

\subsubsection{The Simple Retrieval and Burden Soll Separation senario}

Scenario II (see Figure 4-6) proposes a simpler overall system than the sophisticated SDS scenarico. Tabie 4-1 shows that it dies not use any of the SDS subsystems, at least as such, and that several different sorting options are considered for comparative purposes and are dependent upon future disposal decisions. A sinpler retrieval subsystem is proposed based on temporary buildings being constructed over the pit(s) or series of trenches. The recontainerized input waste is then transported to a more permanent preprocessing and treatment hub. The Soils Processing Subsystem

$\therefore$ S. T. Kujawa MSE Inc. private communicaion, September 3991. 


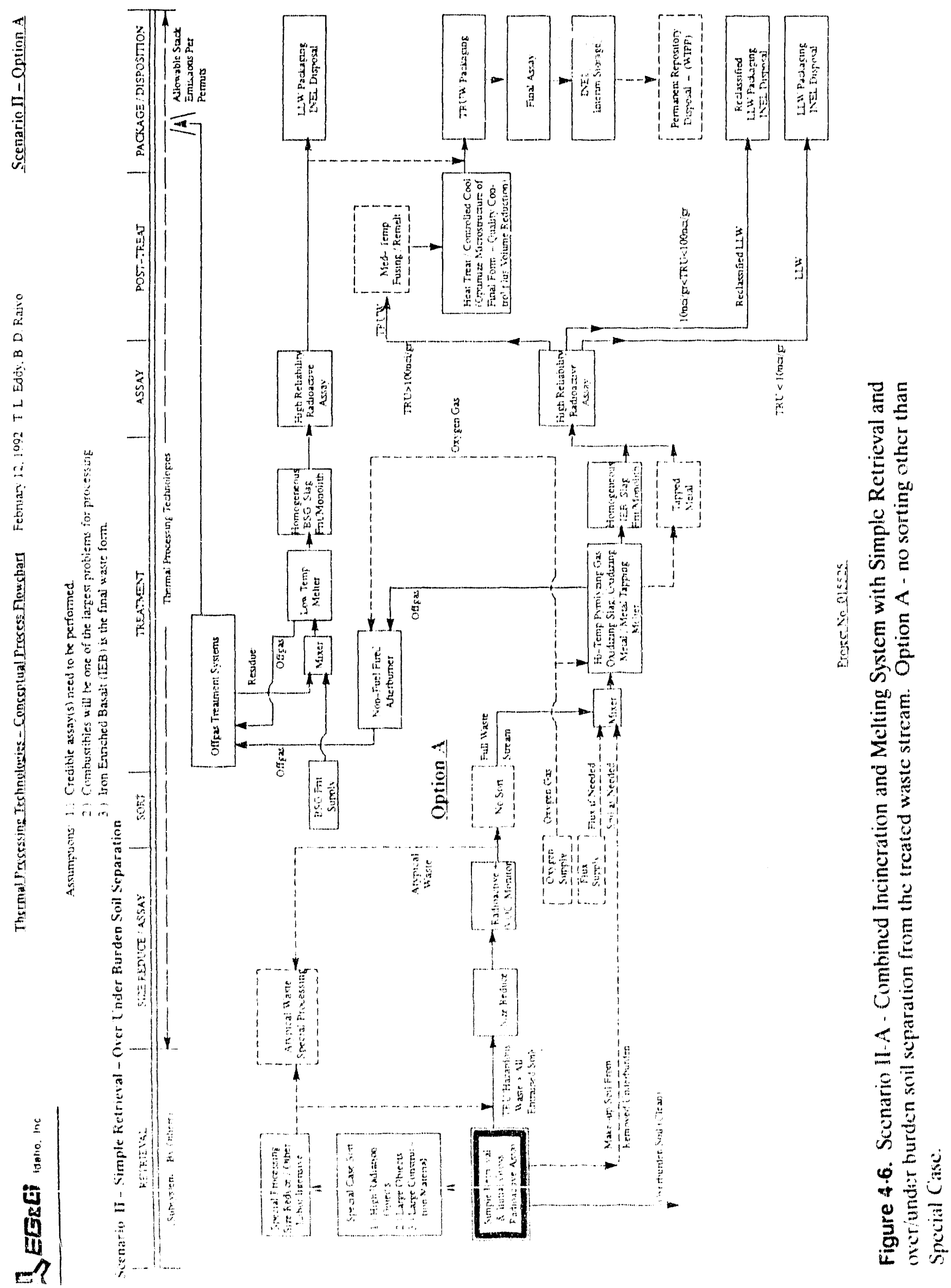


is not used in lieu of using the soil as the base for dissolving the waste streams with excess soil being treated in the same treatment subsystems. The Metals Decon Subsystem is not used because metals decontamination or total oxidation will be done in the melting process.

The simpler retrieval system separates special waste cases as above, separates the overburden soil which is probably the least contaminated, and possibly the underburden soil which may be significantly contaminated down to the lava basalt. The contaminated soil within the trenches or pits and surrounding the containers or other objects will be designated "entrained" soil and would be included with the waste stream. An initial assay of bulk objects identifies potential radioactive problems during retrieval. The details of such a system are beyond the scope of work and resources available at this time, but might be represented simplistically by temporary building(s) within which remotely operated front-end loaders feeding the buried containers and boxes into intermediate containers for transportation to the shredder/crushers contained in the more permanent processing building. (Such a retrieval system has recently been designed in more detail.) ${ }^{g}$ The Processing building would also contain all the treatment facilities, on-site labs, etc. It could have a terminal for transport of the waste form elsewhere or use an expired area building for reburial purposes.

The burden soil is used as needed to augment the dissolution of the waste streams in the best final waste form glassy/rocky state possible. The waste plus entrained soil plus specially processed Special Case materials are sized in a shredder/crusher to approximately $50 \mathrm{~mm}$ (2 in.) to promote reasonable assay, classifying, feeding, and treatment conditions. (The INEL/MSE plasma centrifugal reactor at Butte, Montana, handles up to $100 \mathrm{~mm}$ (4 in.) sizes without problems.) An on-line assay is then performed to verify radioactive content for safe operation.

All five options for sorting (and resultant treatment) of the input waste stream are included: (A) and (E) no sorting, (B) sorting combustibles only which includes organic-laden soil, (C) sorting combustibles from noncombustibles (including organic-frec soil) from metals, and (D) sorting metals only as shown in Figures 4-6 to 4-10. Each sorting option requires different treatment systerns which are a part of that option. The mixers in the treatment functions may be optional depending on the mixing capabilities of the melter chosen.

In Option A (see Figure 4-6). the waste and entrained soil are not sorted lurther. Soil and llux are added to obsain optimum waste form chemistry and lluidity, if needed. The melacr must be a high-temperature, pyrolyzing-gas, oxidizing-slag meler $\|$ be able to mell basaltic soil, pyrolyze combustibles in the gas phase and metals in the melt/slag phase, as well as dissolve the noncombustibles into the slag. The pyrolyzed gases are completely oxidized in an afterburner. Few melters have demonstrated such capabilities with one notable exception.

The INEL/MSE Retech PCR moller at Butte has recently completed several RWMC feed runs simulating waste loadings for $1 / 3$ to $1 / 1$ ratios of metal to INEL basaltic soil and for a $1 / 6$ mass ratio of combustibles with heating values ranging from $9(k)$ to $2(x)$ BTU/L. The metals and combustibles were combined with the soil as the input waste stream. After processing essentially all the combustibles and metals were oxidized and the slag exhibited characteristics of being mostly crystallized (rocky), which is the preferred final waste form, not vitrified (gluswy). Note that the combustibles were not only pvrolyzed but oxidiced. The exidation was apparently entanced by the plisma torch gas penetrating the slagmelt like an air lance. Questions remain about the disposition (1) the HVPM and the Ce surrogate lor the TRU Pu. Other melters that may be able to provide

g. C. C. Lommis, personal communication, EG\&G ldaho, December 1991. 
similar results are any are-plasma melters which can pyrolyze or tolerate oxidizing conditions in the gas phase and produce it in the melt. Low-temperature glass melters and medium-temperature JHM are unacceptable for this role because they cannot melt the metals as required.

All options include the possibility of generating a slag frit or monolith depending on disposal option decisions. The frit can be made into small $10-15 \mathrm{~mm}(1 / 2 \mathrm{in}$.) pieces that can be properly assayed for type and extent of radioactivity, or into monoliths. Assaying will determine the appropriate TRUW, reclassified LLW (10-100 nCi/g), LLW, or Clean disposal options. If the frit option is decided upon. the TRUW frit can be fused or remelted for monolith packaging at $1200-1400^{\circ} \mathrm{C}$, hence, a medium-temperature melter. The following heat treatment may require heating to $1000-1200^{\circ} \mathrm{C}$ depending on the recrystallization process to be used. The LLW waste frit would be either remelted or solidified by an approved, aceeptable method. After fusing or remelting the frit, it should be cooled slowly or a specified controlled cooling cycle followed to obtain the optimum crystalline microstructure for maximum leach resistance.

All options route the offgas from the incinerator and melter(s) to a special offgas treatment facility that is designed to separate the HVPM and other toxic or radioactive substances. These processes will vary with pollutant and are to be determined elsewhere. It is proposed that the residue be evolved as a frit to be assayed for type and extent of radioactivity and then dissolved in a low-temperature BSG glass melter. The expected low quantity of material suggests that further separation of TRUW and LLW streams is inappropriate here. Very little TRUW is expected, so the waste is packaged for LLW disposal.

Option B (see Figure 4-7) is almost identical to Option A. The combustibles are sorted out and run into a thermal desorber (pyrolyzer) from whence the organics, the cemented/silicated organic bearing chunks, and the nitrate olfgases (NOX and $\mathrm{O}_{2}$ ) are fed to an incinerator, such as a rotary kiln. The thermal desorber may or may not be necessary depending on tests with heterogeneous compositions or subsequent findings. The smaller soil and cement particulates are routed to an oxidizing-slag, metal-tapping, high or medium temperature molter. Operating mode will depend on whether the metals can be surface oxidized or must be melted and oxidized. The choice will be determined by subsequent testing. Offgas may be routed to the incinerator or offgas treatment as necessary.

Option C (see Figure 4.8) is identical to Option B except that the waste stream is separated into combustibles, noncombustibles, and metals. The noncombustibles are dissolved into a nonoxidizing medium-lemperature melter for improved maintenance. The metals are routed into a smaller high/medium-temperature, oxidizing-slag, metal-tapping melter with the ane choices of operation as Option B.

Option D (see Figure 4.9) is also identical to Option B with the exception that only metals are sorted out of the waste stream (to) the extent that is eonvenient). In practice. Option B may degenerate to Option D il it is difficult to separate soils with and without organics or chunk-sized construction materials from cemented silicaled organics. Option D may require a larger incinerator than Option B but a similar-sized melter because all the uncombusted material will end up in the melter. A ain, the melter will operate at high or medium temperatures depending on whether surface-metal or toral-metal oxidation is required. Figure 4 - 10 also illustrates the cryogenic fracture size reduction and air-liquifaction plant sptions. The air-liquifaction plant would provide both liquid

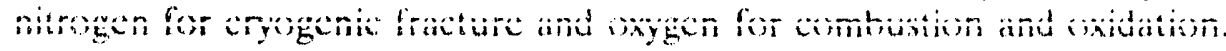




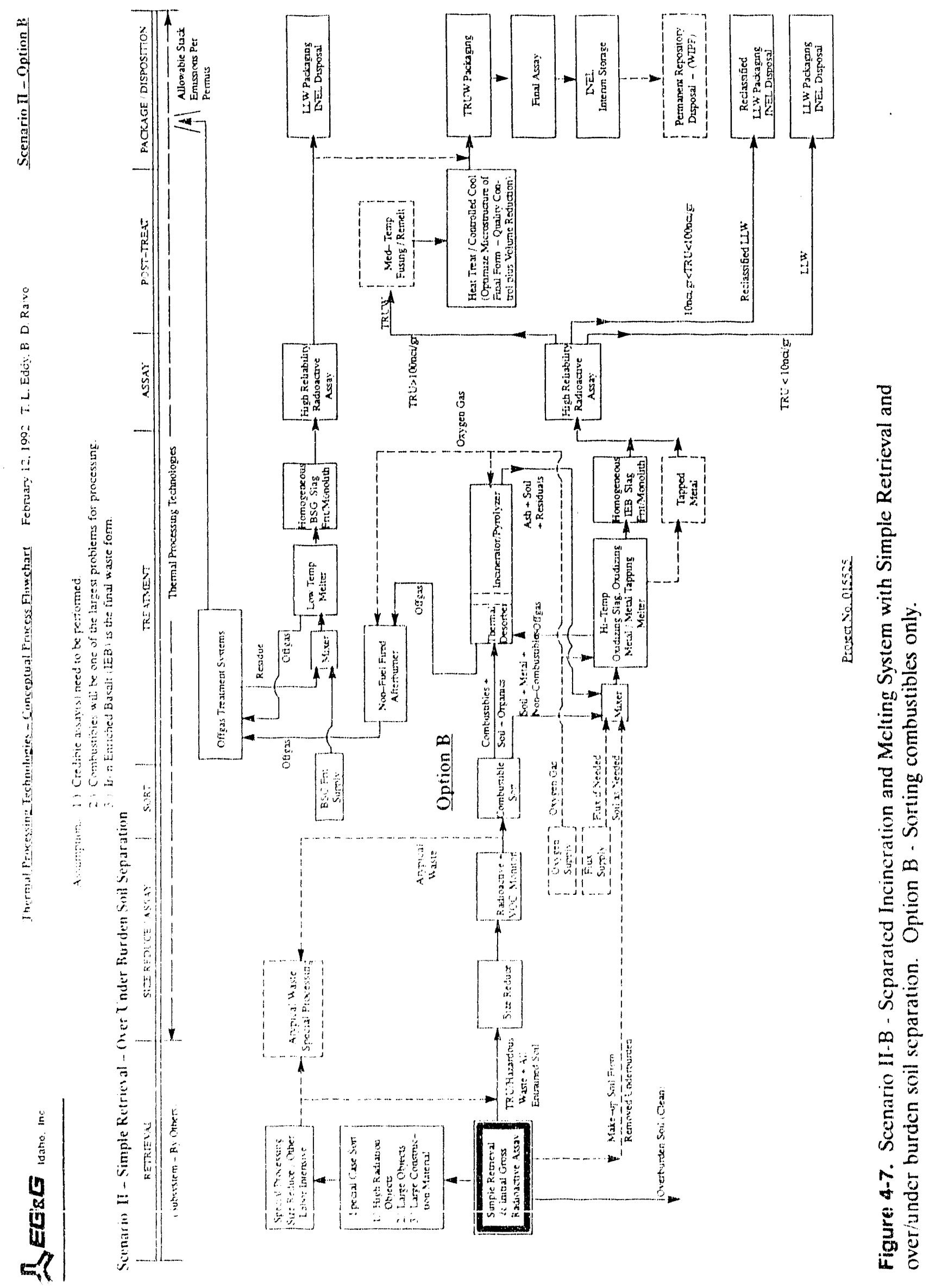




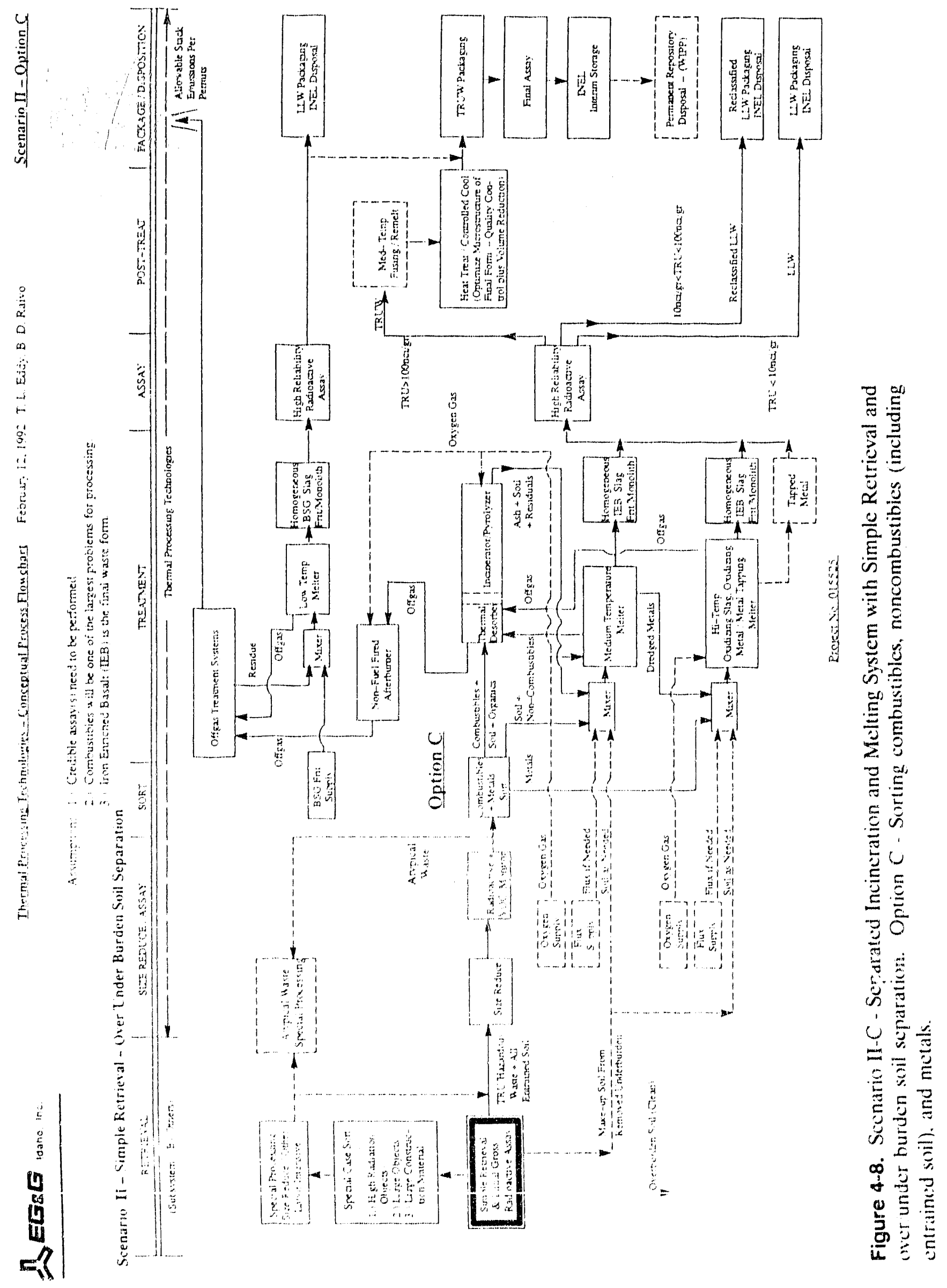




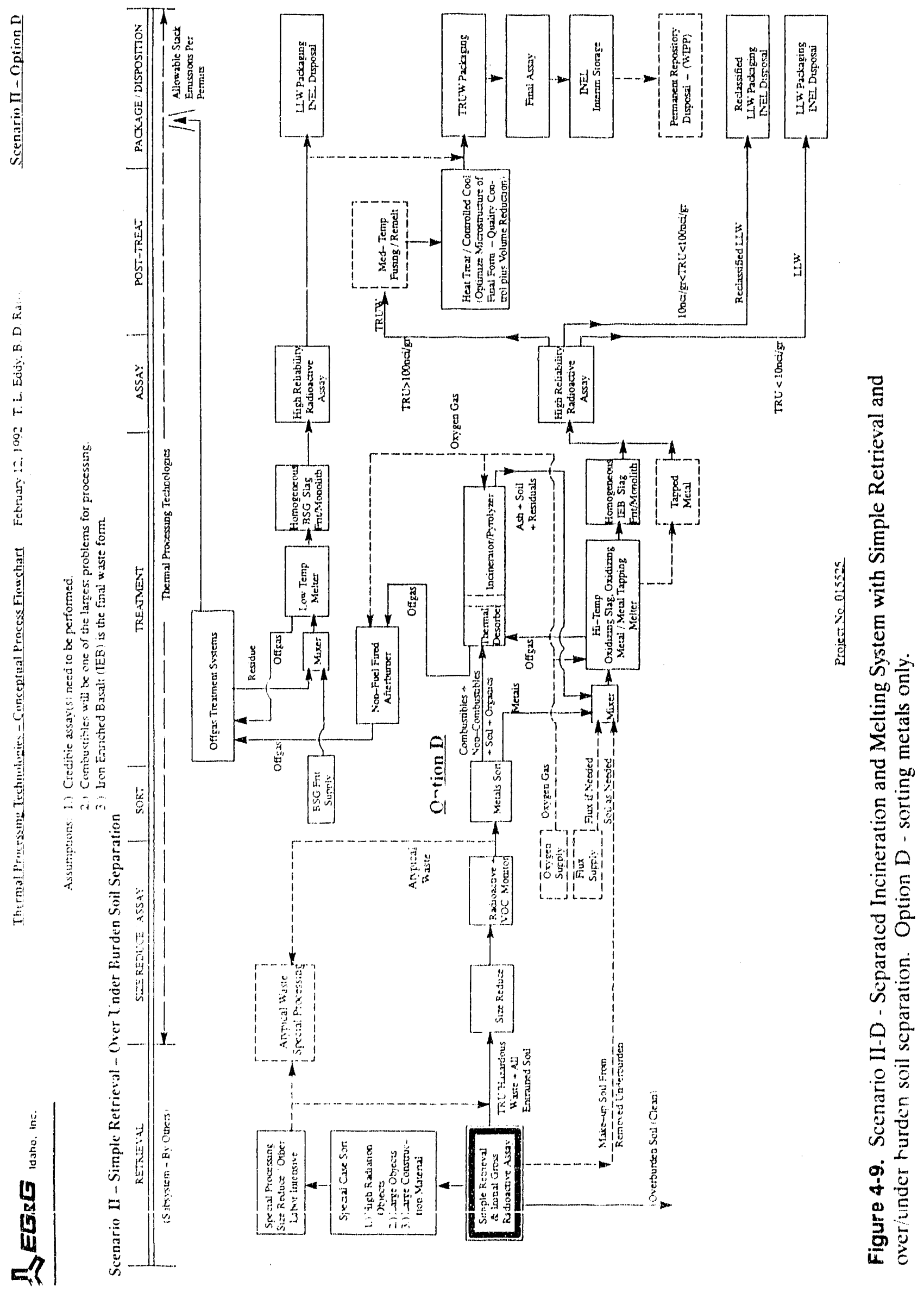


Option E (see Figure 4-10) is also identical to Option B with the exception that there is no sorting. In practice, Option B and D may degenerate to Option $E$ if it is difficult to separate the various waste streams as indicated. Option E may require a slightly larger incincrator than Option $\mathrm{B}$ or $\mathrm{D}$, but a similar-sized melter because all the uncombusted material will end up in the melter. Table 2-6 gives the masses of the material categories. Of the metals, the steel drums would go through the incinerator with their contents anyway. Special case materials, such as large machines, vehicles, etc. would not go through the incinerator. The noncombustible building materials are less than $10 \%$ of the other TRUW. The net added metal material required to go through the incinerator is probably about $30 \%$ more than in Option B. In addition, the incinerator will preheat these other materials via the incineration, thus reducing both the energy and the residenee time required in the melter. The melter will operate at high or medium temperatures depending on whether surface-metal or total-metal oxidation is required. Figure 4-10 also illustrates the cryogenic fracture size reduction and air-liquifaction plant options. The air-liquifaction plant would provide both liquid nitrogen for cryogenic fracture and oxygen for combustion and oxidation.

A comparison of the sorting options A-E is given in Table 4-2. Relative quality points are assigned as indicated below the table and cover sorting, safety, maintenance and cost on a relative, but qualitative basis. Ten points are given if an option does not have an incinerator or second meiter. The total number of points is close. The no sort, incinerator plus melter option (E) leads the way because of a combination of simplified sorting, control, safety and slag consistency. The metals only sort option (D) is second because of identical advantages, but requiring the additional metals sorting. The no sort Option A is third, mainly because of single unit operation plus no sorting. It falls behind Options $E$ and $D$ because of the more complicated melter control and maintenance required. These results are qualitative but do confirm concerns about the four options. Option E also has other advantages not considered in Table 4-2, such as redueed energy and residence time requirements.

\subsubsection{The SDS Retrieval and Total Soil Separation Scenario}

Secnario III (sec Figure 4-11) is identical to Scenario II, but utilizes the SDS Retrieval Subsystem as discussed in the SDS Secnario I (see Table 4-1). The entrained, as well as the burden soil, is separated from the containerized and special-case waste streams. In Scenario Ill, the soil is used to provide the base material for dissolution of the nonsoil waste streams with the exeeption of the offgas treatment system (see Scenario II) that used BSG frit. Excess soil will be processed as a waste stream in the melter option selected.

\subsubsection{The SDS Retrieval and Soils Processing Scenario}

Scenario IV (see Figure 4-12) is identical to Scenario 11, but utilizes both the SDS Retrieval Subsystem and the SDS Soils Processing Subsystem of the SDS Scenario I (see Table 4-1). Therefore, the total soil is separated from the containerized and special-case waste streams by the Retrieval Subsystem and the soils are then processed by the Soils Processing Subsystem. Special options are indicated on Figure 4.12 for this scenario. In Option $\mathrm{K}$, the TRU-contaminated soil (plus any LLW soil needed) is used for the melter makeup soil; whereas, the LL.W soil is solidified or packaged. This option would contaminate the nonsoil waste streams with TRU-contaminated soil, increasing its average contamination level. An alternative is Option 1 , in which the small amount of TRU-contaminated soil is assayed for type and extent of radioactivity, then melled in a low-lemper the BSG glass melter 4 minimize vaporzation, and poured into monoliths for TRUW

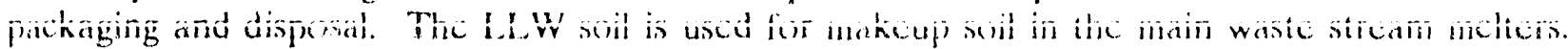
This will tend to dilute the TRUW effect. Option $\mathbb{L}$ appears to be the best choice here. 


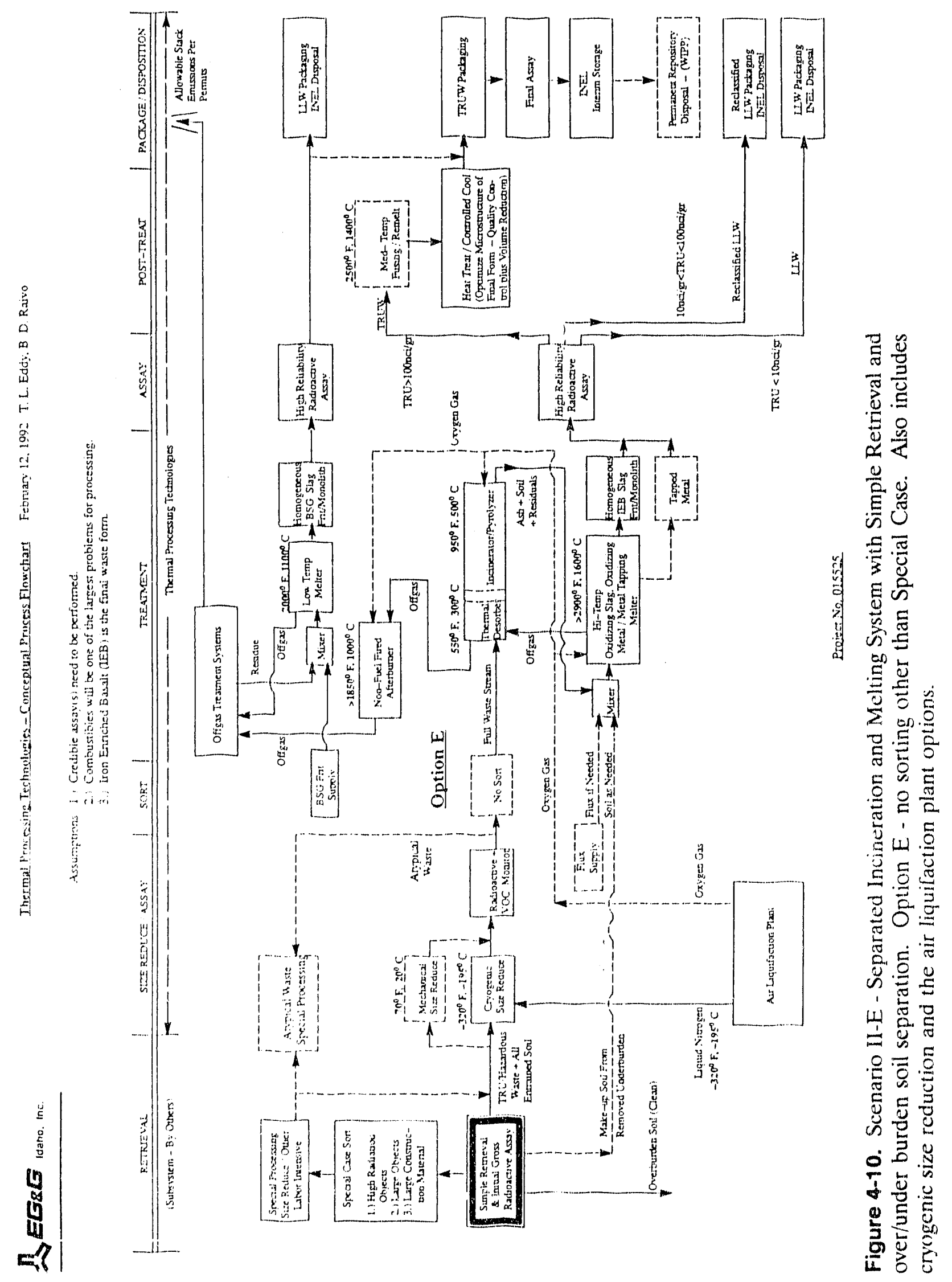


Table 4-2. Comparison of input sorting Options $A, B, C, D \& E$ a $^{a}$

\begin{tabular}{|c|c|c|c|c|c|}
\hline Quality & None & Comb & $\begin{array}{l}\text { C } \\
\text { NonComb } \\
\text { Comb } \\
\text { Metal }\end{array}$ & Metal & None \\
\hline Sorting ease & 10 & 6 & 4 & 8 & 10 \\
\hline Control of Incineration ${ }^{b}$ & 10 & 8 & 8 & 8 & 8 \\
\hline " " Melter 1 & 6 & 8 & 8 & 9 & 9 \\
\hline$" \quad$ Melter $2^{b}$ & 10 & 10 & 9 & 10 & 10 \\
\hline Slag consistency Melter 1 & 4 & 8 & 9 & 9 & 9 \\
\hline$" \quad$ Melter 2 & 10 & 10 & 9 & 10 & 10 \\
\hline Safety of sorting & 10 & 6 & 4 & 8 & 10 \\
\hline Safety of Incinerator & 10 & 8 & 8 & 9 & 9 \\
\hline " Melter 1 & 6 & 9 & 8 & 8 & 9 \\
\hline " "Melter 2 & 10 & 10 & 10 & 10 & 10 \\
\hline Maintenance of Incinerator & 10 & 8 & 8 & 8 & 8 \\
\hline " $\quad$ Melter 1 & 4 & 6 & 6 & 6 & 6 \\
\hline " $\quad$ Melter 2 & 10 & 10 & 8 & 10 & 10 \\
\hline Cost of Incinerator & 10 & 8 & 8 & 8 & 8 \\
\hline " " Melter 1 & 6 & 8 & 8 & 8 & 8 \\
\hline " Melter 2 & 10 & 10 & 10 & 10 & 10 \\
\hline Quality Points & 136 & 133 & 125 & 139 & 144 \\
\hline \multicolumn{6}{|c|}{$\begin{array}{l}\text { a. Relative quality points awarded on the basis of excellent-10, very good-8, good- } 6 \text {, fair- } 4 \text {, and } \\
\text { poor-2. }\end{array}$} \\
\hline
\end{tabular}




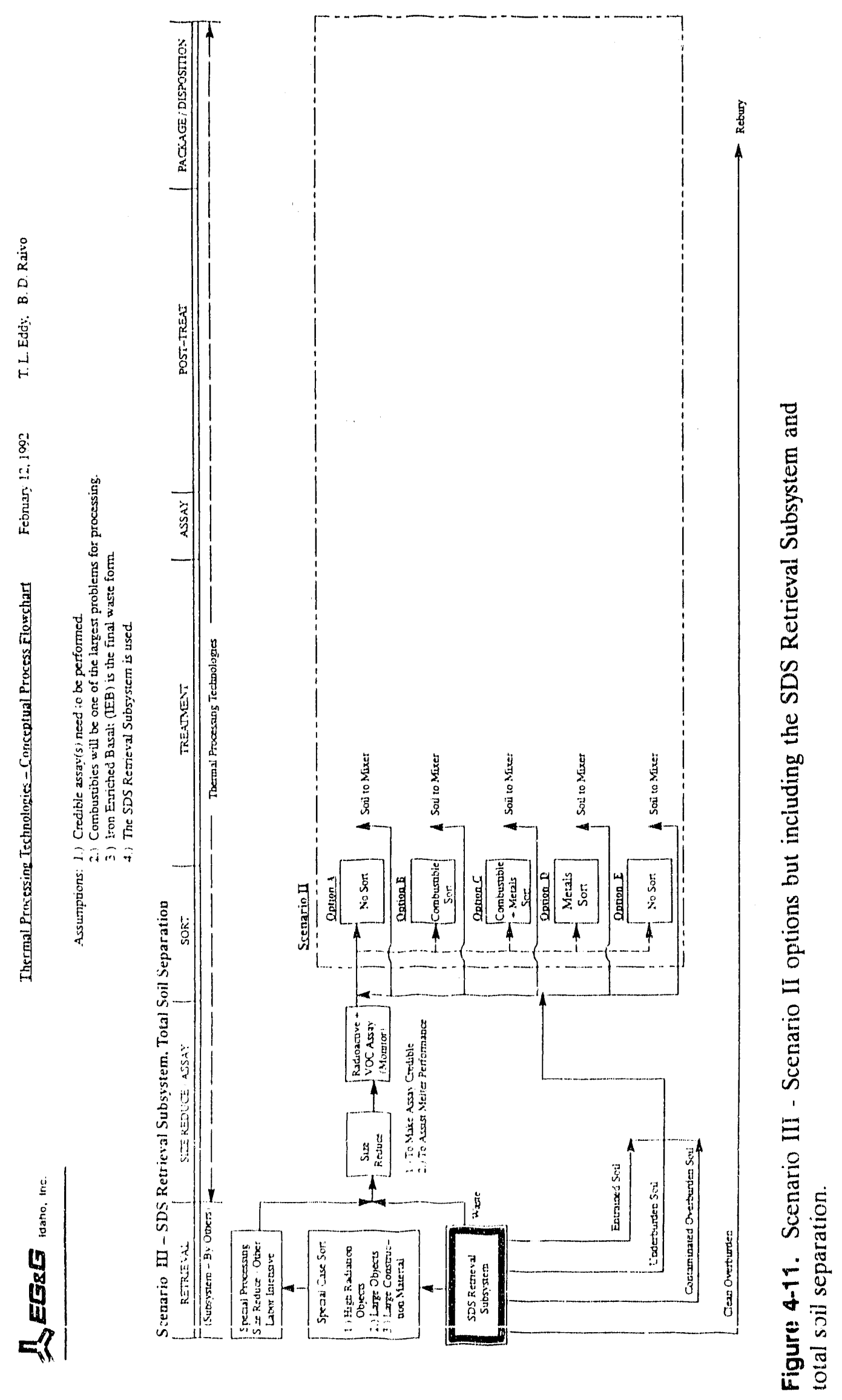




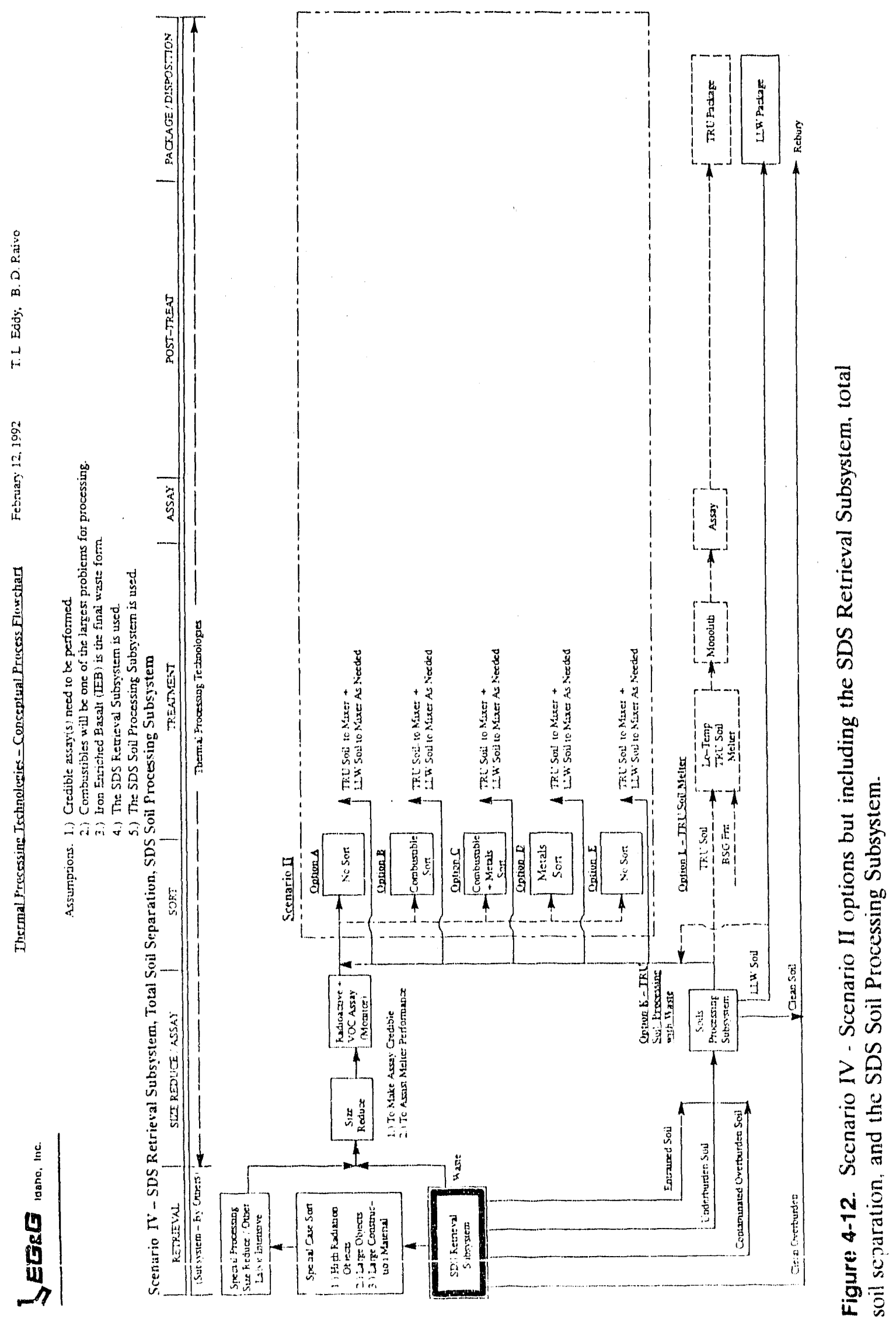




\subsubsection{The Borosilicate Glass Scenario}

Scenario V (see Figure 4-13) is similar to Scenario IV, but uses BSG as the makcup "soil" or glass material. Both the SDS Retricval and Soils Processing subsystems are employed. The TRU-contaminated soil is processed as in Option L which was with BSG. Options A, B, C, D, and $E$ then use BSG for makeup instead of INEL basaltic soil. The advantage of BSG is that lower-temperatures can be used in the melter while maintaining fluidity, but only as long as the waste streams do not have a high metallic content. A high metallic content converts a predominantly borosilicate glass into a predominantly iron-enriched basalt ceramic so that nothing is gained by using the BSG unless many times the waste stream mass is consumed. This would drastically increase the final waste form volume to many times the input waste volume which is an impractical solution.

In the IEB research, it was found that an average INEL TRUW could be combined with INEL soil in a $100 / 0$ to a $0 / 100$ ratio range and still make a high quality IEB final waste form (see References 2,6$).^{58}$ It is, therefore, much more appropriate to use the available contaminated soil, that must also be treated, in the oxidizing-slag, metal-tapping, metal-processing melters at high temperature than attempting to use BSG in a medium-temperature melter, requiring several times the waste mass plus extensive flux to maintain fluidity. The only viable use for BSG is in the noncombustible waste stream melters of Option C. This option had the least number of quality points in Table 4-2 and represents one of the most complex options without obvious benefits. It appears that BSG will be most appropriately used for encapsulating special low-flow waste streams at low temperatures to discourage vaporization and yet provide a simple proven system.

\subsubsection{Comparison of Scenarios and Options and Recommendations}

The SDS Scenario I is used as a comparison base case and has been modified to meet more detailed requirements; hence, it is not a viable option. The Borosilicate Glass Scenario $V$ has been shown to be impractical as a scenario because the final waste form will be a form of iron-enriched basalt unless a glass mass many times the waste mass is used. Scenarios II, III, and IV differ mainly in the use of (II) a simpler retrieval subsystem, (III) the SDS Retrieval Subsystem, and (IV) the SDS Retrieval and Soils Processing Subsystems. It is not known if the TRU Clean/Clear system of the SDS Soils Processing Subsystem will work. We know that the melters can process this soil effectively and therefore eliminate Scenario IV as viable. This also eliminates the need for Options $\mathrm{L}$ and $\mathrm{K}$.

The main differences between Seenarios II and III are (a) the physical form of the retrieval subsystem and (b) whether the entrained soil will go with the waste stream or the soil stream. There appears to be about ten times as much soil in the entrained and burden soils as needed to assimilate the 'TRUW/LLW waste. The preferred sort/treatment option is Option $E$ with an incinerator and melter but no sorting. It, therefore, would be frugal to keep as much contaminated soil with the waste stream as possible to reduce sorting, handling, and potential contamination while providing the soil makeup needed for the melter(s).

The solution for the system design is becoming clearer. A simple retrieval system not necessarily unlike the SDS Retrieval Subsystem, routes all the potentially contaminated soil with the main waste stream. Size reduction and salety assay are followed by Option D (metals only sort) or possibly Option A or E (no sort). The recommended scenario is II-E presented in Figure 4-10.

Additional questions regarding the recommended Scenario II-E include the following. The: thermal desorber may or may not be necessary. Tests with heterogeneous compositions or additional information from other sources need to be arranged. The operating mode of the melters will depend 


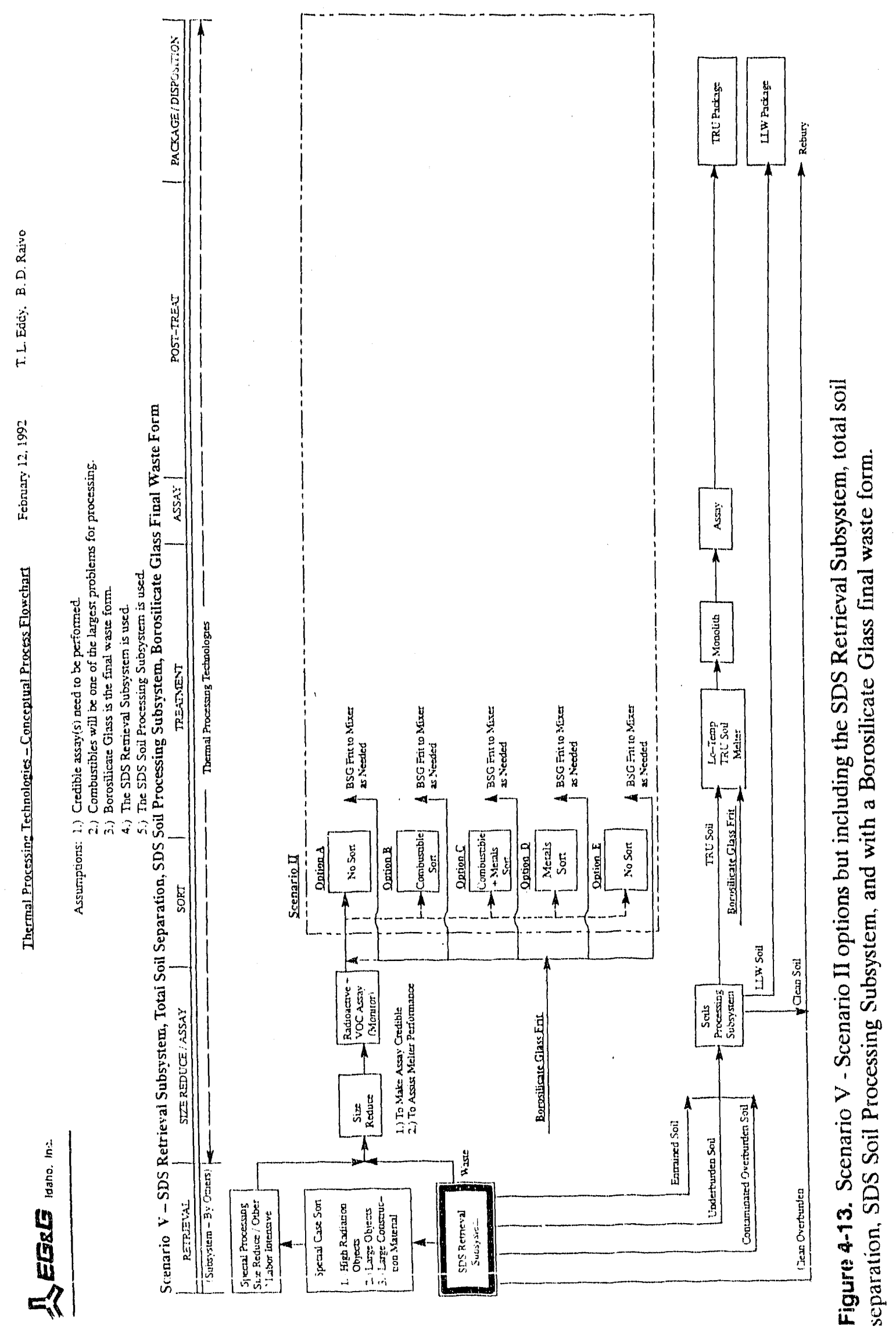


on whether the metals can be properly surface oxidized to remove the TRU or must be totally melted and oxidized. This choice needs to be determined by subsequent testing. Assaying soil and frit should be reviewed or tested 10 determine limits of the assay. Other testing will be required to optimize processes in the melter.

\subsection{Radiological Assays}

As described earlier in this report, the buried mixed wastes and contaminated soils at the SDA represent a highly heterogeneous input waste stream for any treatment process. Although the bulk of the waste materials expected to be encountered have been generally identified, considerable uncertainty exists as to the exact quantities and distributions of these materials. These uncertainties are related to unknowns in original waste coding practices, the relatively lower accuracies used for initial waste assays, and the varied disposal practices of the times. Degradation of containers over time and further degradation likely during retrieval will further increase these uncertaintics. The potential also exists for encountering some presently unidentified materials.

In order to achieve a safe, effective, and efficient process, the treatment process must be highly robust and accommodating to potential input material variations. The final waste form material must atso be sufficiently uniform and moasurable to categorize it for final disposition as LLW or TRU. ${ }^{59, \mathrm{~h}}$

High uncertainties are associated with present radiological assay technology capabilities for TRU waste. As a result, measurements and controls used for process operations activities must include large margins to accommodate the degree of uncertainty. The uncertainties are associated with the heterogeneous nature of the waste matrix. the unknown radionuclide distribution, wide material density differences, matcrials self-shielding, and the short time available for examination in a production operation.

For the purposes of waste processing following retrieval of intact containers, it is generally felt that a good job of characterizing and assaying the waste "as is" can be done by existing analytical methods, by investing large amounts of time on a per container basis. ${ }^{\text {(i) }}$ Using this approach to attempt processing a bulk rate of tons per day of retrieved materials, which will not necessarily be in intact containers, is clearly impractical.

Figure 4-14 illustrates various lypes of assays and their requirements across the processing speetrum. In the front end of the ex situ thermal processing system, an initial assay is assumed to be performed during retrieval operations (by others). This initial assay is viewed as likely having a very high uncertainty due to large uncertainties in existing assay technology relative to heterogeneous unknown waste materials and opportunities for error at higher throughput rates. Although some work is being done to develop improved radiological assay capability, the results are uncertain. The thermal processing system seenarios presented in this report outline methods intended to increase the redibilities (decrease uncertainties) of radionuclude assays required for process monitoring and control by lessening the degree of error in application of any assay technology associated with bulk processing. The process approach tatien is to first place the waste in a physical form (by sizing) which will improve the accuracy and resolution of a bulk rate assay performed by any existing and forthooming assay technology and, second, 10 assay several puints both before and after the thermal

h. B. C. Anderson (Westinghouse Flectric. WIPP), personal compersation, Regulatory trends and future requirements for rad-waste disposal sites. 


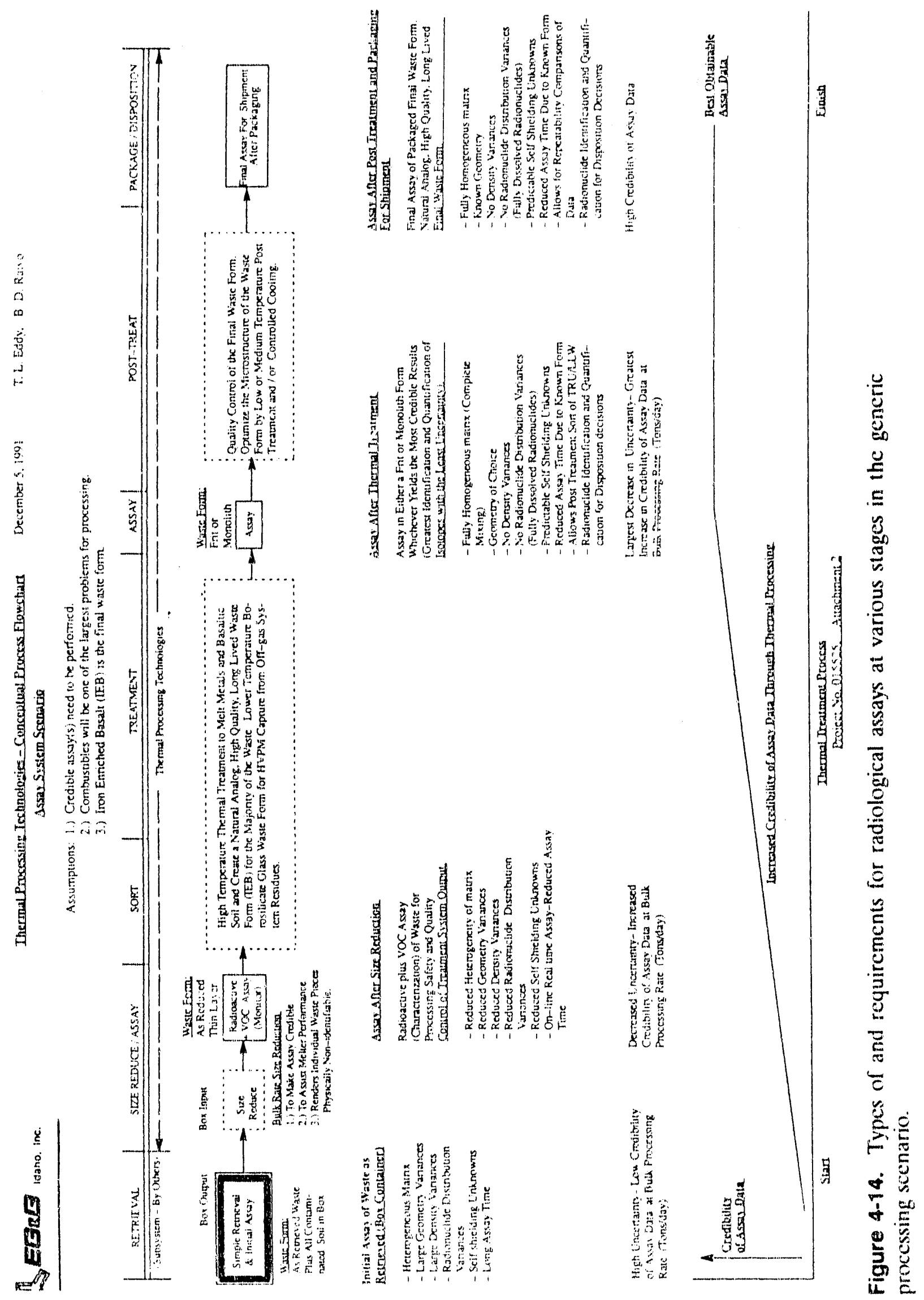


processing steps and again after final packaging. On the input feed stream, bulk size reduction will lessen the measurement uncertainties tied to heterogeneity, radionuclide distribution. density, and self shielding. The extent of the required size reduction will depend on the degree of ertainty ohtainable from the selected/developed assay technology, but the realistic limit is viewed as being in the $1-2 \mathrm{~cm}$ range. The numbers obtained from the assays used for process monitoring and control purposes are to ensure safe and product effective processing operations. A final assay of the waste form is performed at the output of thermal processing operations, which will yield a further improved degree of credibility (e.g., homogeneous frit or monolith). This post processed assay is expected to provide the highest quality assay since the material will be very homogeneous by this point. It is further proposed to perform an assay for shipment purposes after packaging and just prior to shipment.

\subsection{Processes in the Melter}

Several processes are identilied whith affect the internal operation of the melter. In general, these processes can be eategorized into three areas: physical processes in the melter, chemical processes in the melter, and the vitrification/devitrilication processes in the final waste form. These three processes internal to the melter are interrelated to the production of the aceeptable final waste form for final disposal. These processes are discussed below, along with aspects which need to be refined to improve operation of a treatment plant.

\subsubsection{Physical Processes in the Melter}

Relevant properties that influence physical processes internal to the melter and are required to be controlled within certain ranges include melt temperature, melt viscosity, melt corrosivity to the melter refractory materiats, melt electrical conductivity, and the melt thermal conductivity.

\section{Melt Temperature}

The operational ceiling temperature of a melter is limited by the erosion of the electrode materials and melter configuration used. The ceiling temperature limits the melt formation temperature of a slag and subsequently the type of the waste form product produced, i.e., more durable high lemperature glass-ceramics vs less durable low temperature glasses. The melt temperature has a direct effect on the volatilization of HVPM, but the loss will be dependent on transport by convective diffusion which is tied in with viseosity and its dependeree on temperature and composition. The melt temperature can be effectively controlled by the addition of alkaline, alkatine carth, and boren oxides into the melt; but these materials ean increase the leach rate and reduce the effective lifetime of the final waste form.

Melt Viscosity

The viscosity of the melt is inversely related to the mell temperatures. The viscosity of a slag melt at a certain temperature can be lowered by the addition of alkaline and alkaline earth oxides, horon exide, ard phosphoric pentoside; or raised by the addition of high valency oxides such as $\mathrm{SiO}_{2}$. $\mathrm{Al}_{2} \mathrm{O}_{3}, \mathrm{TiO}_{2}, \mathrm{ZrO}_{2}$, ete. Excessive addition of the latter oxides can freeze up a melt, requiring plasmat melting or jack-hammer removal. A highly fluid alkaline slitg melt is not $(00)$ dexirable because it will increase the rate of slag corrosion on the melter refractory materials as the slag moves against the refractories. A high alkaline slag is not $t o 0$ desirable either because the final waste form produced from this kind of slag will not ho very leach resistant. Choosing a proper value of viscosity at a certain temperature is critical to pouring of the slag mell for casting as well as for producing an acceptable final waste form. 


\section{Melt Corrosivity To Melter Refractory Materials}

The corrosiveness of a slag is a function of the alkaline oxide or phosphoric pentoside contents in the melt. The higher the contents of these materials, the more corrosion of the melt to the melter refractory materials. The corrosion increases when the melt becomes very fluid because the rate of interaction/reaction between the slag and the refractory interface increases. In order to prevent excessive corrosion of the melter refractory materials, the alkaline oxide or phosphoric pentoside contents in the melt should be critically controlled. The relative reactivity between slag and refractory can contribute to corrosion. The so-called acidic or basic nature of the slag and refractory compositions must be considered and the refractory must be chosen to minimize reactions for the typical slag composition. Convection near the slag-wall-atmosphere interface also increases the corrosion rate by increasing concentration gradients and mass transfer coefficients. Pilot síudy tests of different refractories under actual convective conditions should be made. Bench-scale validation of suitable newly-developed refractories should be initiated, similar to those on the prior INEL IEB research (see Reference 6). The corrosion resistance of graphite to an IER melt as a function of temperatures should be tested.

\section{Melt Electrical Conductivity}

The melt electrical conductivity is directly proportional to the melt temperature. The slag conducts electricity through the cations and anions. In a slag melt containing a significant number of alkali ions, the transmission of electrical current is primarily due to alkali metals because the mobility of the monovalent alkaline ions is much higher than other hivalent metal ions. For this reason, the addition of alkaline ions into a slag mell at constant electric current will increase its electrical conductivity and lower the Joule heating effect in the melt. Consequently, the melt temperature will decrease. A loss or lowering of the Joule heating effect may cause freczing of the melt. The addition of bivalent metal ions, for example $\mathrm{Ca}$, into a melt will only lower the melt viscosity but not the melt temperature (Joule heating effect) as long as alkaline ions are present.

\section{Melt Thermal Conductance}

The viscosity of a slag melt has strong influence on the thermal conductance within the melt. The thermal conductivity of the melt increases with increasing temperature because of the increased dielectric nature and mobility of cations and anions. The viscosity of the melt decreases with increasing temperature because of the gradual change from a solid to a liquid to give increased melt Ruidity. The thermal gradients in the melt induce recirculation which homogenizes the melt composition, makes the temperature more uniform, and increases the diflusion-limited reaction rates within the slag. Thermal convection also increases with melt nuidity. The thermal conductance in the melt is a function of both conduction and convection, but is mainly influenced by convection at the higher temperatures. Modeling design studies should be initiated to determine appropriate melter geometries using available FIDAP finite difference and GPP slag chernistry codes.

\subsubsection{Chemical Processes in the Melter}

Relevant chemical processes which are internal to the melter and require attention include combustion and pyrolysis, disposition and influenec of the halides, oxidation of metals, and slatg-chemistry processes.

\section{Combustion and Pyrohsis}

The combustibles in the incoming waste stream are organic materials. They may be incinerated priot 10 entering the melter. Two operating modes coukl be used in the melter to handle the combustibles: pyrolysis (the vaporization and breaking down of complex organios) or oxidation by combustion. Pyrolysis has she advantage of minimizing and buffering any sironger combustion 
reactions that might occur in the melter. The pyrolysis mode might create a reducing environment in the slag melt leading to poteritial metal (iron) partitioning from the slag (iron replaced by aluminum, chromium, ete. in the oxide). A reducing slag melt has the potential of volatilizing the HVPM from the melt, but most of them will be in oxide form and will not be reduced by any exeess iron. In the oxidation mode, most of the combustibles would be oxidized in the melter, with the rest in an afterburner. The slag melt woukd be subjected to an oxidizing environment, oxidizing the metals. Oxygen could be supplied above the melt to assist oxidation, or delivered through the slag melt by a gas bubbler. The technology for delivering oxygen into a slag melt has been well developed in the pyrometallurgical industry. Potential volatilization of gas phase suboxides of the HVPM, e.g., lead suboxides, from the melter might occur, requiring offgas collection and treatment. The redox state of the melt influences or is an indication of volatilization of HVPM, slag and ultimate waste form chemistry, and the stage of process development. The extent of and location of combustion and pyrolysis will inlluence the redox state in the melt.

\section{Disposition and Influence of Halides}

The disposition of halides, particularly chlorides, can be important. Chlorides in the melt will lower melting points, thus increasing volatilization of the HVPM. Most of the halides will be directed to the offgas system where they will be collected, whether via an incinerator or melter oxidation. Some chlorides will end up in the melt. Their effect needs to be checked to determine its signilicance. Monitors could be installed on the melter system to notify operators when excessive amounts are in the slag so corrective action (e.g., adding TRU-contaminated soil) can be taken.

\section{Oxidation of Metals}

Metal decontamination can oceur via surlace oxidation of the contaminated metals. The oxidation of metals can be considered from either the surlace oxidation or the total oxidation scenario. In the surface oxidation scenario, the metals contaminated with TRUs would enter the slag/melt bath, the TRUs would be dissolved into the slag melt with the surlace metal oxidation, and the decontaminated metal would then be dredged or melted and tapped. In this case, the melter would be required to operate at a near-neutral oxidizing condition. The melt temperature may not be as high as the melting temperature of the metal, if dredging is used. Surface oxidation of metals may not be easy to both control and handle without preliminary studies to determine the efliciency of the process, identifying problem areas to be overcome, and developing eriteria for sizing, agitation, and other procedures. Bench-scale studies of metal surface oxidation to indicate profof of principle are needed. Concentrated studies in the pilot plant would be needed to consider the effects of the mefter configuration. convection, metal orientation, the need for bubbling, etce on the actual surface axidation efficiency.

In the total oxidation scenario, the metal would be completely oxidized and dissolved in the mell with additional oxygen delivered into the melt to assist oxidation. To hasten oxidation, the metal dimensions need to be reduced and the melt agitated by bubbling, electromagnetic stirring, or equivalent. Total metal oxidation may he an important problem because, if required, it may lengthen the residence time to undesirable periods. Bench- scale studies should be initialed in concert with surface oxidation to determine methods to reduce the potential residence time without adversely affecting the other desired propertices of the slag melt.

\section{Slag-Chemistry Processes}

The slag-chemistry process is the most important part of the melter operation because it deials directly with the fathrication of the linal waste form and its performance characteristises. There are wereral important parameters to be considered in the fabrication of an acceplable high integrity final woste form as follows: 
- Retention of HVPMs in the slag. It is desirable that the volatilization of the HVPM be minimized even at high temperatures. Any vaporized metals or metal oxides would condense and be collected as particulates in the offgas treatment system. Retaining them in the slag would simplify the process. The volatilization of the HVPM is closely related to the redox state and the temperature of the melt. The incorporation of the HVPM into the slag would be enhanced if the melter is operated under oxidizing conditions. Tailoring the slag chemistry to produce high temperature ceramic phases which can dissolve the HVPM such as Pb, Zn, Cd, ete. to form stable compounds or solid solutions is highly desirable. Bench-scale tailored-design studies of the slag chemistry should be focused in this direction 10 maximize the retention of HVPM in the slag.

- Retention of TRU radionuclides in the slag. The slag melt must be able to dissolve the TRUs and incorporate them in its matrix. The TRU metals are extremely reactive and would form oxide compounds or oxide solid solutions with alumina, titania, and zirconia to produce mineralogical hollandite, perovskite, and zirconolite phases. These phases occur in Synroc, a hot isostatic pressing (HIPPIN(j) process at modest temperatures, and have demonstrated excellent product performance characteristics. Tailoring the slag chemistry to produce these high temperature erystalline phases which will retain the TRU species in an IEB matrix are highly desirable. Detailed tailored design studies on the slag chemistry should be focused on methods to improve the retention of TRUs in the IEB4, $\mathrm{ZrO}_{2} / \mathrm{TiO}_{2}$ modified IEB, type of slag. Bench-scale studies with rare-earth lanthanides as surrogates for the TRUs should be initiated at the INEL Research Center (IRC), as well as specific tests with TRU at Test Area North (TAN).

- Retention of LL radionuclides in the slag. The slag-chemistry condition to capture the LL in a slag is similar to those of the TRUs. Rare-earth lanthanides may not be the proper surrogates for the LL. Nonradioactive isolopes of the LL could be used in the tailored slag-chemistry investigations. IEB4 is also expected to be an excellent matrix for LL retention. IRC bench-scale tests for TRUW and LLW simulated wastes should be performed concurrently. Bench-scale tests concurrent with TRU-retention tests at the site should be performed to prove and confirm the less expensive surrogate experiments.

Some experiments have been performed on the volatility of $\mathrm{Cs}$ from the melters. In prior IEB research at the INEL, eesium oxide was expected to evaporate from the melt at a rapid rate, but this was shown not to be true [see Reference 6]. Some of the cesium remained in the slag and some evaporated. The conditions to retain the $C s$ in the slag need to be investigated with nonradioactive $C s$ as an ideal surrogate. Fxperiments with Cs will probably indicate the mechanisms to retain other HVPM as well or indicate that it is impractical. This subject warrants further work.

- Redox State of the Mell. The ratios of $\mathrm{FeO} / \mathrm{Fe}_{2} \mathrm{O}_{3}$ (or $\mathrm{Fe}^{2+} / \mathrm{Fe}^{3+}$ cations) in the slag indicate the redox state of the mell. The ratios of $\mathrm{Fe}^{2+} / \mathrm{Fe}^{3+}$ cations are optimal between $0.1-0.5$ in terms of avoiding undesirable unstable foaming and precipitation of metallic species during processing. Tailored design studies on proper conditions of the redox state in the melt may be applied to gencrate a high density and high viscosity slag foam to capture escaping HVPM at high temperatures. The redox state appears to be related to many of the results from matcrials characterization of mineral (glass and ceramic) states incleding recrystallization remperatures. Its walue may be used as it 
gauge to meter the formation process of the desired waste form. Other studies should include determination of the redox state of the melt to provide a base of information from which to determine if a focussed study relating redox state to final waste form characteristics and processing conditions is warranted.

- Electrode corrosion and crosion. The melter operation scenario could involve oxidizing or reducing environments. The interaction of the clectrode material, e.g., graphite or copper, with oxygen would create a serious corrosion problem. Other chemical reactions may occur due to the complex composition of the off gases. Metal alloys have been developed for electrodes operating in pure ovygen. Graphite electrodes with SiC coatings have been developed to minimize oxidation of the graphite. Electrode erosion can also be a problem if high current loading of the electrodes oecurs. Metal electrodes used in high erosion applications usually employ thick dimensions to lengthen lifetime. Graphite electrodes in the scrap melter/smelter industry are consumable electrodes which are advanced as they are used up. The decision as to which type of electrodes and melter configuration should be determined in Phase II of the SDS. Bench-scale test results and/or existing vendor experimental data should be obtained to provide explicit information on electrode corrosion with IEB slag.

\subsubsection{Vitrification/Devitrification Processes in Slag}

There is a great deal of evidence that leach resistance can be increased by crystallizing the slag as it cools into the final waste form. The crystals are usually more leach resistant. Recrystallization or devitrification occurs at different temperatures for different minerals, and hence over the temperature-time cooling curve. The minerals have different composition than the bulk material; therefore, the remaining glass is depleted of the elements in the crystals and the remaining elements increase in composition in the glass. The alkalis are usually not part of the crystals that form at the higher temperatures. They are found in the relatively low lemperature feldspars and some pyroxenes which form in the last stages of solidification. If the slag is cooled quickly, the alkali-containing crystals do not form and the alkalis are in the vitrified, amorphous glass. The alkali glass is also more easily leached than the crystalline structure and deteriorates the structure as a whole over time. The deterioration increases the surface area of the crystalline material, thus decreasing its leach resistance.

Slow cooling of the slag produces predominantly crystalline phases including the feldspars and pyroxenes containing alkalis. A variable cooling and possibly heating schedule has been used (1) first nucleate and then grow desired crystals on a limited basis. Controlled cooling would, therefore, allow a manipulation of the vitrification and devitrification processes in the slag to produce the desirable durable ceramic phases with an engineered grain size. These controlled cooling processes have been shown to produce a final waste form with much superior product performance characteristics than many other waste forms (see Reference 6). ${ }^{61}$ Prior experiments on controlled cooling demonstrated proof of concept and just started parametric studies to optimize the cooling profile with time. Experiments to determine nuckation temperatures for desired mineral phases and cooling profiles for IEB/IEB4 compositions to become an approved waste form for TRUW are needed.

\subsection{R\&D to Optimize the Waste Form and Processes}

The present state of the art in rotary-kiln incineration and plasma-heated melters is such that a treatment lacility for demonstration and subsequent operation could be designed today and operated in the near future. The various leasibility and more advanced design studies have identified 
appropriate methods for site classification, retrieval, treatment, assaying, packaging, and a good waste form. Material handling, incinerator, and offgas treatment systems are now available.

The waste management R\&D performed over the past 15 years has contributed to and resulted in this conclusion. The research results on the IEB waste form are no small contribution and have set the stage of confidence in the waste form and how to make it. Pit 9 has been sufficiently characterized. Retrieval methods have been appropriately simplified. Several waste stream sizing methods are available. Complex sorting methods are unnecessary. Containment methods are being linalized. Incineration methods for mixed LLW were developed and operated at Process Experimental Pilot Plant (PREPP) and Waste Experimental Reduction Facility (WERF). Plasma-heated melters have successfully made very leach resistant waste forms from feeds spanning the range from INEL soil (A-100) to soil with much metal and organic material (A-40). TRAMPAC containers have been designed and tested.

Further studies can improve many aspects of the system, including the quality of the waste form and the overall efficiency of the handling and treatment processes for making that waste form. These studies would run parallel to the next preliminary design phase focussed on the specific type of components to be installed. Topics for additional R\&D 10 optimize the system and waste form, as well as proposed testing, follow.

\subsubsection{Recommended R\&D and Priorities}

The purpose of this section is 10 identify valuable $R \& D$ areas in high-temperature melter processing of the RWMC buried mixed TRUW. These topics are intrinsic to the melter processes and will have important conseguences for the final waste form product performance characteristics Laboratory-scale tests are needed to provide solutions to these problems and to generate guideline: for optimizing pilot-scale design and tests. Environmental, heath, and safety constraints only allow bench-scale non-radioactive surrogate tests at IRC. Simulated surrogate tests will portrait possible seenarios for real TRUW conditions. It will be necessary to perform TRUW bench lests at the Site or elsewhere to investigate or confirm these scenarios. Other possible constraints are available facilities and manpower.

Several questions have been identilied that are in need of research and development work. The listing of the topies is randem and does not reflect any chronological order of importance. However, these topics are coupled (attempts to understand one topic need to consider the others) as follows:

- Dissolution and retention of HVPM in the slag melt

- Dissolution and retention of TRU and LL in the slag melt

- Refractory corrosion in the melter

- Combustibles and redox state in the melter

- Metal dissolution and oxidation

- Electrode corrosion and erosion

- Volatility of $\mathrm{Cs}$ from the melter.

Initial lirst series tests have begun 10 address some of these concerns. Tests have been conduced at PEC for plasma jet melting of INEL soil spiked with HVPMs, at MSE for the plasmatare centrifugal-reactor melting of INEL soil and simulated RWMC wastes, and at PNL. for crucible melt tests of pure INEL soil with $74 X$ simulatcol waste streams. 
The nature of the various topics have been discussed above. Future bench-scale research and development work is discussed below.

\subsubsection{Proposed Testing}

HVPM - Tailoring the slag chemistry to produce high temperature ceramic phases which can dissolve the $\mathrm{HV}^{\prime \prime} \mathrm{M}$ such as $\mathrm{Pb}, \mathrm{Zn}, \mathrm{Cr}, \mathrm{Cd}$, etc. to form stable compounds or solid solutions are highly desirable. IRC bench-scale tailoring design studies on the slag chemistry should be focused in this direction to enable the retention of HVPM in the slag.

Dissolution and retention of TRU and LL in the slag melt - Tailoring the slag chemistry to produce the high temperature $\mathrm{ZrO}_{2}$ or TiO $\mathrm{TiO}_{2}$ IEB4 phases, which will retain the TRU species in stable compounds or solid solutions in an IEB matrix, are highly desirable. Bench-scale tailoring design studies on the slag chemistry should be focused in this direction to enable the retention of TRU in the siag. Bench scale with rare-earth lanthanides as surrogates for the TRU should be initiated. TRU bench-scale tests should be performed to prove and confirm the surrogate experiments. IEB4 is also expected to be an excellent matrix for LL retention. Bench-scale tests for TRUW and LLW simulated wastes should be performed concurrently.

Refractory corrosion in the melter - The corrosion resistance of graphite or carbide crucibles to an IEB melt shoinld be tested at different temperatures. Bench-scale validation of suitable newly-developed refrictories should be initiated, similar to those on the prior INEL IEB rescarch (see Reference 6).

Combustibles and redox state in the melter. Bench-scale tailored design studies should bo focused on the proper conditions of the redox state in the melt to generate a high density and high viscosity slag foam to capture escaping HVPM at high temperattures. Other studies should include determination of the redox state of the melt to provide a base of information from which to determine if a focussed study relating redox state to final waste form characteristics and processing conditions is warranted.

Metal dissolution and oxidation - Bench-scale studies of metal surface oxidation to indicate proof of principle are needed. Lab studies eould simulate the pilot plant melter to consider the effects of the melter configuration, convection, metal orientation, the need for bubbling, etc. on the actual surface oxidation efficiency. Bench-scale studies should be initiated in coneert with surface oxidation to determine methods to reduce the potential residence time witho dversely affecting the other desirea properties of the slag melt. Bench-scale tests on metal oxidation should focus on its relation to the redox state of the melt and product phases formation.

Electrode corrosion and erosion - Bench-scale studies should focus on surface protfection of the electrode and the electrode tip geometry on high current crosion. Bench-scale studies and existing vendor experimental data should be obtained to provide explicit information on electrode corrosion with IEB type of slag.

Volatility of $C s$ from the melter - The high retention of $\mathrm{C}$ s in IEB at high temperatures contradicts the conventional expected behavior of $\mathrm{Cs}$. Bench-scale studies should focus on the volatility of $\mathrm{C}$ s with other oxides as a function of temperature to either confirm or deny previous results. Experiments with Cs will probably indicate the mechanisms io retain other HVPM as well as indicate that it is impractical. 
Melter modeling studies - Modeling design studies should be initiated to determine appropriate melter geometries using available FIDAP finite difference and GPP slag chemistry codes.

Controlled Cooling . Prior experiments on controlled cooling demonstrated proof of concept and just started parametric studies to optimize the cooling profile with time. Experiments to determine nucleation temperatures for desired mineral phases and cooling profiles for IEB/IEBA compositions to become an approved waste form for TRUW should be performed.

\subsubsection{Potential Collaborators to Solve Problems}

A number of university, National laboratory, and commercial/industrial collaborators are available for collaboration to solve problems. Some of them are listed in Table 4-3. 
Table 4-3. Potential researchers and collaborators to solve problems.

\begin{tabular}{ll}
\hline \multicolumn{1}{c}{ Vendors } & Government/National Laboratories \\
JHM & Burcau of Mines-Albany/ASME: \\
Glasstech & INEL/EG\&G S\&T \\
Penberthy & INEL/EGSG Site \\
AHM & INEL/MSE \\
Electromelt & INEL/WINCO CCP \\
Electropyrolysis Inc. & LLNL-Molten Salt \\
Elkem Technology & Los Alamos \\
& PNL-Battelle \\
PHM & SRL-Westinghouse \\
Retech & Universitics \\
Plasma Energy Corporation & Colorado School of Mines \\
Cupola & M.I.T. \\
Westinghouse & SUNY-Bullato \\
Scorpion Mig. & U. Idaho \\
Other & U. Missouri-Rolla \\
Hazen Associates & U. Minnesota \\
SAIC-WTMD & U. Utah \\
& \\
\hline
\end{tabular}




\section{FIRST TEST SERIES RESULTS}

\subsection{Review of the First Test Series}

The First Test Series is a number of experiments involving melters and/or melting from which information can be gleaned. The lests include the following.

1. PEC Test: Plasma heated melting of INEL soil and metal nitrates in a stationary melter pot using a nontransferred (plasma) torch at the Plasma Energy Corporation (PEC) facility.

2. ACT Test: Arc heated melting of INEL soil and diesel fuel in a centrifugally rotating meiter pot using a transferred (arc) torch at the INEL/MSE Component Development Integration Facility (CDIF) as a afterburner component test (ACT).

3. RWMC Test: Similar to the ACT test but with variations of simulated RWMC feeds including metals, combustibles, HVPM (Pb), and TRU (Ce).

4. PNL Test: Similar to the RWMC Test, but under JHM conditions, performed in externally-heated crucibles and with alkali flux to obtain fluidity at lower temperatures.

Tests 1-3 were initiated prior to this work and Test 4 was a part of this work. A Melter Shakedown Tesi was devised for quick proof of whether existing JHM and PHM could melt or process INEL soil and TRUW. The RWMC and PNL tests are related to the Melter Shakedown Test procedures. The RWMC test processed all options without problems. The PNL Tests are still not complete, but have demonstrated the difficulty in processing metals and INEL soil in low or medium temperature melters $\left(900-150()^{\circ} \mathrm{C}\right)$.

\subsection{Melter Shakedown Tests}

Several major questions were raised about melter capabilities to process INEL soil and TRUW. These questions were initially addressed in some First Test Series experiments. It is a popularly conveyed concept that JHM technology for waste treatment is state-of-the-art with numerous vendors with JHM (and processing techniques) sitting on the shelf awaiting purchasers. Plasma-heated melter technology, on the contrary, is believed to be new and in a research and development stage in spite of the fact that electric-arc furnaces have been smelting and melting metals and controlling slags for decades.

The first Melter Tests set up were to test existing melter technologies against their claims, e.g., proof of principie type tests. It proposed six simple tests that could be run at the vendors facility or at an installation or lab. Measurements only included power and mass data and slag temperature under operating conditions. Slag samples were to be returned to INEL/EG\&G Idaho, Inc., for materials characterization. The six tests simulated RWMC TRUW and were to answer the simple questions:

- Can you melt INEL basaltic soil to fluidity without llux?

- Can you melt INEL basaltic soil with flux"? How much is required?

- Can you melt soil and metals with flux?

- Can you melt soil and metal oxides with llux? 
- Can you melt soil and metal oxides and HVPM with flux?

- Can you melt soil and metal oxides and treat organics with flux?

The metals and organics concertrations were analogs of the INEL/MSE RWMC feed tests at the CDIF for comparative purposes.

The results of requests for the PHM tests are the following. The RWMC Test ran both metals and organics at the same time, oxidized both, and yielded the desired predominantly-crystalline final waste form. No tlux was required. The disposition of the HVPM is unknown at this stage of evaluation, but indications are that the lead was both vaporized and retained in the glass matrix of the waste form. The ACT Test results were similar, but yielded a larger fraction of glass phase than the RWMC Test. The PEC Test had previously run INEL soil plus metal nitrates in a PHM with and without alkali flux. The metal nitrates apparently vaporized near the beginning of the test, possibly during feeding, hut the waste form was predominantly vitreous (glassy) phase with the chromium locked in the ystalline (rocky) phase.

The requests for JHM tests were met with nu takers. In the first place, lew JHM vendors are actually available. Those that are available operate predominantly in the low temperature range $(900-$ $\left.1200^{\circ} \mathrm{C}\right)$, and 10 develop an appropriate medium or high temperature melter would require an extensive and expensive $\mathbb{R} \& D$ program. PNL indicated that teses in existing BSG JHM would need to be in large JHM at mass rates of $1000 \mathrm{~kg} / \mathrm{day}(2200 \mathrm{bb} / \mathrm{day})$. Small JHM will not give a good indication of performance because the current stream lines and proximities of the cold walls do not siale. The basaltic soil presented a new challenge and could not be done without a considerable amount of thux $(10-30 \%)$. The vatriable compositions presented thuidity problems in establishing reliable operating points without the danger of freczing up the melter. "The high concentrations of metals were to be excluded from the ests for similar reasons plus the unoxidized metal in the bath coukd short out the current path. PNL. proposed to do a set of crucible tests to identify operating ranges as a function of composition and temperature. After this R\&D eflort, a pilot plant could be designed and constructed to perform the melter tests requested. Other JHM vendors were concerned athout the impact of the chunks of waste materials on stirring impellers and required marble-sized particles.

It appears that the PHM have no problem melting the TRUW, LLW, and soil; are extremely rohust for variable input feed compositions such as found at RWMC/SDA; and can operate under bidising or reducing conditions, hut need to be investigated for the treatment and disposition and if the HVPM. The JHM are nst at the slage of development needed for stabilizing the particular RWMC TRUW LLW Waste strams and considerable development of processes, electrode materials, and refractories, as well as improved sorting and control precedures for the waste stream are required. For additionat information sece Reference 3 .

\subsection{Scientific Experiments}

Soveral tests have been initiated or monitored to evaluate the final waste form characteristics. WTDD intiated the melting of INEL soil and metal nitrates in a Plasma Energy Corporation (PEC) PHM with a nontransferred nitrogen plasma woth in a water-cooled tiltable meiter. After initial heating. the soil and nitrates were fed into the molter through the torch plasma. After melting, the slag was poured onto a bed of sand and cooled over a period of 1.2 hours. As a result of this rapid comling. the microstructure is yuite line with small erystals and dendrites distributed throughout the predominantly glass matrix. The dine is found in the dendrite erystals which are probably pyroxenes. 
The chromium is found in the pyroxene dendrites and as chromite. The alkalis (Na \& $\mathrm{K}$ ) are in the (aluminosilicate) glass phase, and the alkali earths ( $\mathrm{Ca} \& \mathrm{Mg}$ ) are in the glass phase and the dendrites. Leach tests and composition measurements indicated that little of the metals in the added nitrates remained in the slag. Nitrate decomposition temperatures are quite low (around $500^{\circ} \mathrm{C}$ ) so that they may have been decomposed at the beginning.

The ACT and RWMC Test experiments are performed in a Retech Plasma centrifugal reactor wuth a transferred torch operating on air. Oxygen is provided tirough a tube in the gas phase. The lirst slag samples received were from the ACT Series afterburner shakedown tests which melted INEL basaltic soil and $10 \%$ diesel fuel. The waste form resembled black obsidian rock and was predominantly the glassy, vitrified phase with large concentrations of crystals and dendrites throughout the samples. The erystal orientation indicated llow or cooling patterns. The crystals were predominantly ferritic spinel with some chromite and the alkalis were absent, except in the alumina silicate glass matrix.

The RWMC Test series gave different results. This series had $3 / 1$ and $1 / 1$ metals to soil content plus wood chips and diesel fuel as combustibles. The combustibles were almost totally oxidized before reaching the afterburner and the metals were alm ost completely oxidized in the slag via the plasma-torch air lance. XRD measurements did identify a very small amount of free iron in the slag samples. The slag core samples indicated a predominantly erystalline (rocky) phase with some glass phase. The slag is cooled in the pig in the bottom of the reactor chamber for a day and then further cooled in ambient air, taking another day to cool to room temperature. This slow twostage cooling process resulted in larger crystal formation than in the quickly cooled PEC rests. Also the large amount of metal and resulting metal oxide in the slag apparently increased the crystalline content drastically.

Figure 5-1 shows typical micro-photographs of the PEC, ACT, and RWMC with a magnification of 1000 . The crystals in the ACT photograph are approximately 10-micron squares. A comparison of the photographs emphasizes the shift from a predominantly glassy (PEE test) to a predominantly crystalline (RWMC test) waste form.

The PNL. Test results are not yet available for inclusion in this report.

It appears relatively easy to get excellent waste forms from plasma-heated melters. 


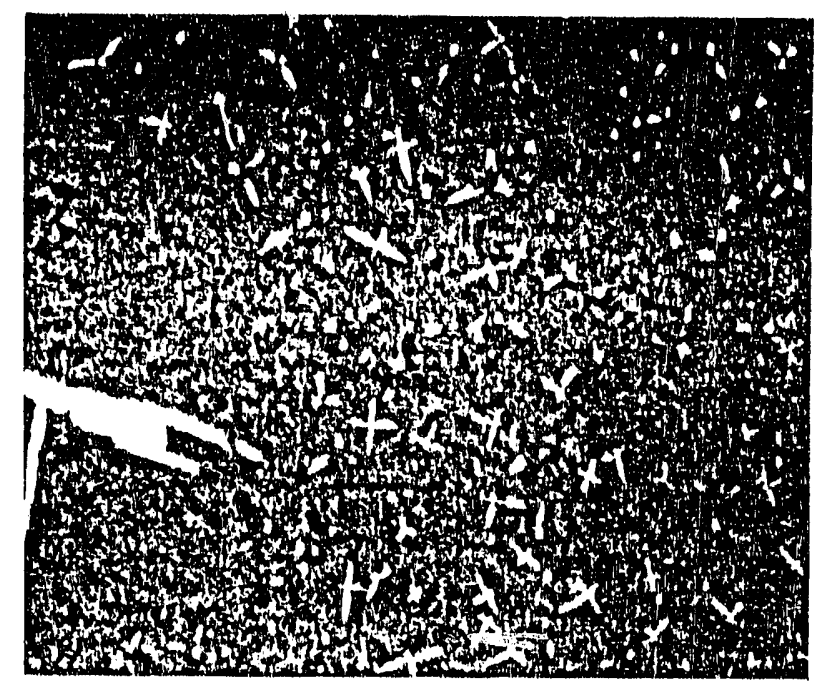

\author{
PEC PLASMA MELTER TEST \\ o INEL SOIL + NItRATES \\ - Rapidly Cooled \\ - Meets tCl.p Requirements
}

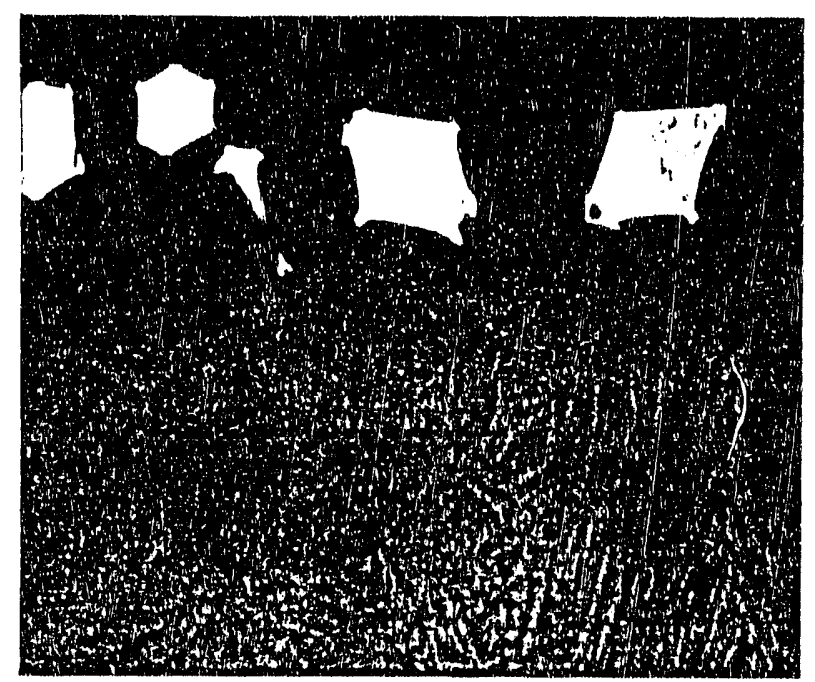

\title{
MSE PAFE ACT TESTS
}

- IIIEL SOIL + DIESEL FUEL

- Slow COOLED

- Half glass \& Half Ceramic (CERAMIC = CRYSTALLINE)

- LOW LEACHING

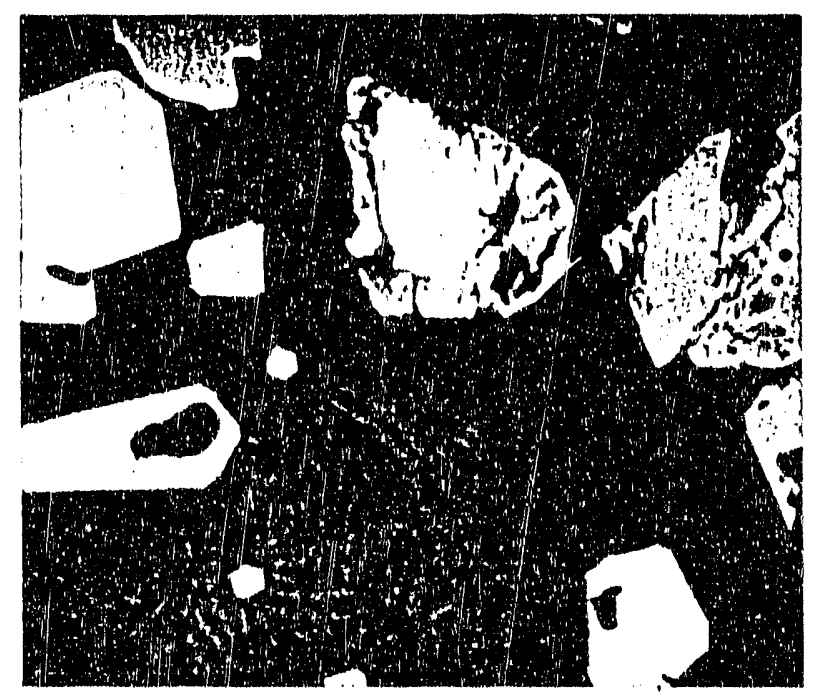

\section{MSE PAFE RWMC TESTS}

- INEL Sotl + Stainless Steel, DIESEl Fuel, WOOd ChIPS, \& LEAd

- SLOWLY COOLED

- Mostly Ceramic

- LOWEST LEACHING

Figure 5-1. Microphotographs of the slag waste form from the PEC, ACT, and RWMC tests (1000X). The PEC slag is predominantly amorphous glass. The RWMC slag is predominantly crystailine rock. 


\section{CONCLUSIONS AND RECOMMENDATIONS}

\subsection{Input Waste Streams}

The TRUW streams from the SDA at the RWMC are predominantly metals, organics in a variety of forms, materials made up of metal oxides, and a considerable amount of contaminated soil. Both toxic and radioactive substances are distributed throughout this heterogeneous mixture. There will be more than ample contaminated soil to stabilize the TRUW, as well as the LLW and toxic materials into a waste form with high leach resistance, long-range chemical and physical stability. Based on this preliminary analysis, the best way to do this safely, simply, efficiently, and with optimum control of the quality of the final waste form is as follows. Size the irput waste for an on-line safety assay and downstream processing. Sort out the metals from the waste and contaminated soil stream for processing in an oxidizing-slag, high-temperature p'asma/arc heated melter. The other waste and soil would be thermally desorbed to pyrolyze gases for the incinerator with the solid mater als routed to the melter. The melter slag could be fritted, assayed to separate TRUW and LLW with the TRUW form being fused, packaged, and transported to WIPP, or an equivalent. Alternately, if the TRU level is below $100 \mathrm{nCi} / \mathrm{g}$, the blended TRUW/LLW waste form could be paci:aged for reburial. HVPM that escape the slag will be collected and dissolved in a low-temperature Joule-heated melter with a BSG waste form.

\subsection{Final Waste Forms}

It has been determined that borosilicate glass is an inappropriate waste form for the high-metal and basaltic-soil contents in RWMC buried wastes. The low waste loadings required to force feed BSG would result in a significant increase in final waste volume instead of reduction. The few applications in which BSG could be used would require additional development costs and more complex sorting, waste stream composition control, and melter control systems which outweigh the benefits. It has also been demonstrated that JHM op ration at high-temperatures is not state of the art and much development of the JHM itself would be needed. The same is not true of Plarma/archeated melters which have already demonstrated the fabrication of a desirable waste form from RWMC types of waste streams. The R\&D can then focus on the refinement of the processes utilizing state of the art compnents.

\subsection{Processing Systems}

The recommended processing system scenarios is Scenario II, Option E (see Figure 4-10); it has the highest priority because it has no sorting (excluding special case sorting), the simplest control of incinerator and melter, only one melter, and maximum safety and maintenance.

It requires a less complicated retrieval system (already being designed by others) than the SDS Retrieval Subsystem that sorts out overburden soil which may be clean and passes nonspecial-case waste and other soil to the sizing crusher/shredder ( $<50 \mathrm{~mm}$ or $2 \mathrm{in}$.) and an intermediate assay for safety. The no-sort waste stream is routed to a thermal desorber with the pyrolized gases going to the incinerator and the solids going, with the metals, to a high temperature, oxidizing-slag. plasma/archeated melter. The metals may be surface oxidized, melted and tapped from the bottom of the melter, or totally oxidized and dissolved into the slag. Any combustibles getting to the melter will be at least partially oxidized and routed to the incinerator or offgas treatment system as appropriate. 
If Option X (separate TRUW disposal) is selected, the output slag could be fritted to a size amenable to an assay to separate TRUW and LLW. It has heen shown that a water quench may become contaminated under these conditions, requiring treatment. The TRUW frit can then be remelted or fused, heat treated to obtain the optinum final waste form, and poured into appropriate packaging. If Option Y (rebury blended TRUW/LLW) is selected, the slag could be poured into a monolith in the final packaging and controlled cooling used to obtain the optimum final waste form.

The melter processes need to be tested to determine how to minimize HVPM carryover, including TRU and LL radionuclides. Oxidation, followed by diffusion of the HVPM through a thick slag or foaming layer should reduce the loss into the offgas significantly. Any volatilized toxic or radioactive materials will be collected in the offgas treatment, assayed, dissolved in BSG in a lowtemperature Joule-heated melter, and packaged for disposal. Offgas collection may be by condensation/solidification or other specific process (e.g., for $\mathrm{Hg}$ ). These are $\mathrm{io}$ be determined for specific materials later.

\subsection{Recommended R\&D}

Irrespective of the melter type, the following topics must be addressed in the near future for proper completion of the pilot plant tests:

- Crucible tests of the disposition of HVPM and metal oxides in high-temperature (15(k)$1800^{\circ} \mathrm{C}$ ) processing. This should include As, $\mathrm{Cs}, \mathrm{Cd}, \mathrm{Hg}, \mathrm{Pb}$, and $\mathrm{Ln}$.

- Crucible and melter tests of the retention and dissolution of TRUW and reconfirmation of uranium in zirconia-augmented slags.

- Crucible and melter tests to study metal oxidation and dissolution in the melter in both surface and total oxidation modes. The removal of TRU and LL radionuclides from the surface of metal artifacts would be a major aspect of this topic.

- Melter tests to confirm refractory/skull corrosion effects.

- Melter tests to confirm expected electrode corrosion/erosion effects.

- The redox state in the slag and its influence on the HVPM, as well as controlled cooling processes and their influence on the phase composition of the linal waste form. 


\section{REFERENCES}

1. J. L. Mayberry, W. J. Quapp, F. Feizollahi, J. C. Dei Signore, and J. McFee, Preliminary Systems Design Study Assessment Report, EGG-WTD-9594, June 1991.

2. G. A. Reiman, J. D. Grandy, and T. L. Eddy, Suncey of INEL. Research on the Iron-Enriched Basalt Waste Form, EGG-WTD-10156, January 1992.

3. A. D. Donaldson, R. J. Carpenedo and G. L. Anderson, Melter Needs De'velopment Assessmemt, EGG-WTD..9911, January 1992.

4. M. J. Vigil, Subsurface Disposal Area (SDA) Waste Identification, EGG-WM-8727, January 1990 .

5. Handbook of Chemis $y$ and Physics, The Chemical Rubber Co., 52nd Ed., Cleveland, OH, 1972-72.

6. J. E. Flinn, P. V. Keliey, R. L. Tallman, S. P. Henslec, and W. C. Seymour, Anmual Repom on the TRU Waste Forr Studies with Special Reference to Iron-Enriched Symthetic Basalt. EGGFM-5366, 1980 .

7. W. MeCulla et al., "Treatment of Hazardous Wastes Using Wet Air Plasma Oxidation," 1st INEL Workshop on Plasma Applications to Waste Treatment, Idaho Falls, ID, January 16-17, 1991.

8. M. J. Kirshner, "The Use of Combined Plasma Photolysis in the Treatment of Flue Gases," 1 st INEL. Workshop on Plasma Applications to Waste Treatment, Idaho Falls, ID, Jamuary 16-17, 1991.

9. W. C. Neely and E. J. Clothiaux. "Decomposition of Organic Compounds by Silent Discharge Plasma," 1st INEL. Workshop on Plasma Applications to Waste Treatment, Idaho Falls, ID, January $16-17,1991$.

10. A. Czernichowski and H. Lesueur, "Multi-Electrodes High Pressure Gliding Arcs Reactor and Applications for Waste Gas and Vapor Incincration," 1st INEL W'orkshop on Plasma Applications to Waste Treatment, Idaho Falls, ID, January 16-17, 1991.

11. D. Dalton, E. M. Steverson, and G. L. Anderson, Air Pollution Control in Thermal Treatment, EGG.WTD-10038, January 1992.

12. F. E. Flinn, P. V. Kelsey, Jr., R. L. Tallman, S. P. Henske, and W. C. Seymour, Iron-Rich Basalt-Type Waste Forms for Transuranic and Low-Level Waste Containment: Evaluation of Electromelt Casting, EGG-FM-5241, April 1980.

13. K. D. Recve, D. M. Lrvins, J. L. Woolfrey, and E. J. Ramm, Adv. in Ceram. Vol 8, Nuclear W'aste Maragement, eds. G. G. Wicks and W. A. Ross, 1984, p. 20k).

14. M. I. Goldman, J. A. Servizi, R. S. Danicls, T. H. Y. Tebbutt, R. T. Burns, and R. A. Lauderdale. Proc. 2nd UN Conf. on Peoceful Uses of Atomic Energy Geneva, 1958, Vol 18. p. 27. 
15. R. Eliassen and M. I. Goldman, Hearings on Industrial Radioactive Wast: Disposal, ed. R. C. Doan, 1959, V(1) 3, p. 196(6.1979), U.S. Govt. Printing Office, Washington, DC:

16. C. A. Mawson, Manageme'n of Radioactive Wastes, Van Nostrand, Princelori N.J, 196.5, p. 196.

17. J. L. McElroy, W. J. Bjorklund, and W. F. Bonner, The Treatment and Handling of Radioactive Wastes, eds. A. G. Blasewitz, M. Davis and M. R. Smith, Springer, New York, 1982, p. 171.

18. J. R. Gorver and B. E. Chidley, British Report AERE-R-3178. Alomic Encrgy Rescarch Establishment, Harwell, England, 1960).

19. W. Bocola, A. Donato, and G. Sgalambro, Simp. on the Management of Radioactive Wastes from Fuel Reprocessing, LAEA, Paris, 1972, p. 449.

20. J. L. McElroy, K. J. Schneider, J. N. Hartley, J. E. Mendel, G. L. Richardson, R. W. Mckec, and A. G. Blasewitz, "Waste Solidification Program Summary Report," Vol 11, Evaluation of WSEP High Level Waste Solidification Processes, BNWI.-1607. July 1972.

21. J. A. Kelley, E. I. duPont de Nemours and Co.. Savannah River Laboratory, Aiken, SC, DP1382. May 1975.

22. J. E. Mendel, PNL 3946, Battelle Pacific Northwest Laboratories, December 1978.

23. M. J. Plodinec, G. C. Wicks, and N. E. Bibler, The Technology of High-Leved Nuclear Waste Disposal, Vol 2, ed. P. L. Hotmann, DOE, 1982, p. 336.

24. C. M. Jantzen, M. J. Plodinec, and J. Non Cryst, Solids, Vol 67, 1984, p. 207.

25. C. M. Jantzen and J. Non-Cryst, Solids, Vol 84 (1986), p. 215.

26. E. M. Levin, Phase Diagrams: Materials Science and Technology, Vol 6-1II, ed. A. M. Alper, Academic Press, New York, 1970, p. 143.

27. P. B. Queneau, D. E. Gregar and L. D. May, "Application of Slag Technology to Recycling of Solid Wastes," AIME-SME Annual Meeting, Denver; CO, February 25-28, 1991.

28. J. M. Welch, R. P. Schuman, and J. E. Flinn, Immobilization of Transuranic Sludge in GlassCeramic Materials, EGG-FM-570\%, March 1982.

29. G. J. McCarthy, J. Mat., Sci. Vol 8. 1973, p. 1358.

30. G. J. McCarthy and M. T. Davidson, Am. Ceram. Soc. Bull., Vol 54, 1975, p. 782.

31. R. O. Schochel, Am. Cerum. Soc. Bull., Vol 54, 1975, p. 495.

32. A. E. Ringwood, V. M. Overshy and S. E. Kesson, Proce Seminar on chemistry and Process Engineering for High-Level Liquid Waste Solidification, eds. R. Odoj and E. Merz, July Conf. 42, Vol 1, 1981, p. 495.

33. P. E. D. Morgan. D. R. Clarke, C. M. Jantzen, and A. B. Harker, J. Am Ceram. Soc, Vol 64, [981, p. 249. 
34. J. B. Dunson, Jr., A. M. Eisenberg, R. L. Sehuyler III, H. G. Haight, Jr., V. E. Mello, T. H. Gould, Jr.. J. L. Butler, and J. B. Pickett, DP-1625, E. I. duPont de Nemours \& Co., Savannah River Laboratory, Aiken, SC, March 1982.

35. A. K. De, B. Luckscheiter, W. Lutze, G. Malow, and E. Schiewer, Am. Ceram. Soc. Bull., Vol 55,1976, p. $5(K)$.

36. W. Lutze, J. Borchardt, and A. X. De, Scientific Basis for Nuclear Waste Management, ed. G. J. McCarthy. Plenum, New York, 1979, p. 69.

37. D. R. Clarke, J. Am. Ceram. Soc., Vol 64, 1981, C89.

38. A. B. Harker, D. R. Clarke, C. M. Jantzen, and P. E. D. Morgan, Surfaces and Interfaces in Ceramic and Ceramic-Metal Systems, eds. J. A. Pask and A. Evans, Plenum, New York, 1981. p. 207.

39. C. M. Jantzen, D. R. Clarke, P. E. D. Morgan and A. B. Harker, J. Am. Ceram. Soc, Vol 65, 1982, p. 292.

40. L. P. Hatch, Am. Scientist, Vol 41, 1953, p. 410.

41. B. C. Slaes and L. A. Boatner, Mat. Lett., Vol 2, No. 4B, 1984, p. 669.

42. B. C. Slaes and L. A. Boatner, ORNL-6168, May 1985, Oak Ridge National Lab., Oak Ridge, TN.

43. B. C. Slaes and L. A. Boatner, L. Non-Chyst. Solids, Vol 71, 1985, p. 103.

44. C. M. Jantzen, Am. Ceram. Soc. Abstr., 1986, p. 510.

45. L. Kahl and W. Bernotat, Am. Ceram. Soc. Abstr., 1986, p. 510.

46. E. R. Vance, D. J. Cassidy, K. L. Smith, and J. L. Woolfrey, Ceramic Transactions Vol 9, Nuclear Waste Management III, ed. G.B. Mellinger, 1990), p. 71.

47. H. W. Chan and D. G. Howitt, Ceramic Transactions, Vol 9, Nuclear Waste Management III, ed. G. B. Mellinger, 1990, p. 23.

48. R. C. Ewing and W. Lutze, Ceramic Transactions, Vol 9, Nuclear Waste Management III, cd. G. B. Mellinger, 1990), p. 33.

49. J. R. Bartet, J. L. Woolfrey and W. J. Buykx, Ceramic Transactions Vol 9, Nuclear Waste Management III, ed. G. B. Mellinger, 1990, p. 45.

50. J. M. Welch, R. P. Schuman, S. P. Henslec, and R. L. Tallman, Iron-Enriched Basalt as a Waste Form for High Level Nuclear Wastes, EGG-FM-5758. December 1982.

51. S. O. Bates, In Situ Vitrification Waste Form Product Evaluation Strategy, EGG-WTD-9148, August 1990, p. 15. 
52. USEPA, Toxicity Characteristic Leaching Procedure (TCLP), 40 CFR 268, App. I, U.S. Federal Register, Washington, DC, 1988, p. 728.

53. M. J. Plodinec, C. M. Jantzen, and G. G. Wicks, Scientific Basis for Nuclear Waste Management, Vol 7, G. L. McVay ed., North-Holland, NY, 1984, p. 755.

54. M. J. Plodinec, C. M. Jantzen, and G. G. Wicks, "Advs. in Ceramics," Vol 8. Nuclear Waste Management, ed. G. G. Wicks and W. A. Ross, 1984, p. 491.

55. C. M. Jantzen and M. J. Plodinec, J. Non-Cryst., Solids, Vol 67, 1984, p. 207.

56. C. M. Jantzen, "Advs. in Ceramics," Vol 20, Nuclear Waste Management II, eds. D. E. Clark, W. B. White, and A. J. Machicls, 1986, p. 703.

57. S. T. Kujawa, DOE/EPA SITE Demonstration: DOE Test Plan, INEL/MSE report 2DOE-PAFE-DOO2R1, MSE, Inc., Butte, Montana, April 1991.

58. G. A. Reimann and J. M. Welch, Electromelt Furnace Evaluation, EGG-FM-5566, September 1981.

59. B. C. Anderson, (Westinghouse Electric, WIPP), "Overview of Waste Regulations Defining NDE/NDA Requirements," Transuranic and Hazardous Waste' Characterization Information Exchange, Pocatello, Idaho, July 1991.

(6). Transuranic and Hazardous Waste Characterization Information Exchange, Pocatello, Idaho, July 1991.

61. J. M. Welch, R. L. Miller, and J. E. Flinn, Fuel and Core Storage and Disposal Development: FY-82 Immobilization of Three-Mile Island Core Debris, EGG-FM-6059, October 1982. 


\section{Appendix A}

Source Data for Waste Streams and Scenarios 


\section{Appendix A}

\section{Source Data for Waste Streams and Scenarios}

\section{A.1 Waste Stream Inventory Tables}

The specific buried waste inventory data which was used as background for this report is included as follows. Table A-1 indicates the opening and closing dates for waste locations in the Subsurface Disposal Area (SDA). 'Table A-2 indicates the evacuated container, soil, overburden, underburden and subsidence volume for the trenches and pits of interest. ${ }^{2,1}$ Table A-3 indicates the estimated mass of U, Pu, and Am shipped from Rocky Flats Plan: (RFP) in 1954 through 1970 (see Reference 1). Table A-4 and A-5 give the number and type of containers in each trench and pit, respectively (see Reference 2 and footnote a). Table A-6 gives special eonsiderations for waste buried in pits of interest. ${ }^{3}$ Table A-7 indicates the volumes of eerlain liquid wastes shipped from RFP (see footnote a). ${ }^{4}$ Table A- 8 gives the range of metal was.es in selected trenches and pits (see footnote a). ${ }^{5}$ Table A.9 is a summary of the drum wastes shipped from RFP Aqueous Waste Treatmerit Facility by type and year (see Reference 1). Table $A_{-}-10$ indicates the weight and volume fractions of wastes buried at the SDA." Table A-11 gives a detailed listing of materials known to be buried in Pit 9 and indicates some mass and/or volume data." Additional detailed information on the contents and the location within the trenches and pits, that will he useful during actual remediation, is being generated by Waste Technology Development Department (WTDD) personnel of EG\&G Idaho, Inc.

\section{A.2 SDS Incineration \& Melting Systems}

The system scenarios for treatment pivot around the recommendations of the System resign Study (SDS). "The two treatment systems proposed in the SDS that fall within the work siope of the JHM/PHM applications are Incineration \& Melting with Low-Level Waste (LLW) Presort (2-EG-1) and Incineration \& Melting with LLW Postsort (2-EG-4). In the LLW presort option an on-line assay is made to separate transuranic waste (TRUW) and LLW wastes prior to other sorting procedures common to both systems. Figure A-1 gives the process flow diagram for the system with L.LW presort (see Refierence 7).

The Postsort option is shown in Figure A-2. In the Postsort option, the On-Line Assay between TRUW and LLW and. henec, the ILLW Processing Subsystem are eliminated. With this system, the

a. D. A. Arrenholy and J. L. Knight, "A Brief Analysis and Description of Transuranic Waste Disposal in the Subsurface Area of the Radicative Waste Management Complex at the INEL," WTD-()-(1)16, November 1\%().

b. D. A. Arrenhole and J. L. Knight, "Historical Repert of Transuranic Waste Pits and Trenches at the Subsurface Disposal Area of the Radioactive Waste Maragement Complex at the INEL," WT1) 91-(2)?, August 1991. 
disposal options are the same, but the assay and separation of TRUW and LLW occur after the decontamination of metals, incincration of combustibles, and melting and dissolution.

The common sorting procedures occur at different stages and essentially separate into three classes: (a) TRUW for packaging and storage in a TRUW repository, (b) LLW wastes for separate treatment (from TRUW) and subsequent land disposal restriction (LDR) storage, and (c) clean offgas, water or soils for unrestricted disposal. Additional details are discussed elsewhere (see Section 5.2 and Reference 7).

The Retrieval Subsystem (S-BE-4) is show n in Figures A-3 and A-4. It separates the soils from the non-soil containers, machinery, ete. Ovesized, overly radioactive, and other waste stream materials that would be difficult to handle directly in the system are separated for special case processing requirements.

The Soils Processing Subsystem (S-EB-2) is shown in Figures A-5 and A-6. It separates the soil into TRU-contaminated soil, LL-contaminated soil, dean soil, and clean water.

The LLW Processing Subsystem (S-IT-3), is shown in Figures A-7 and A-8. It incinerates and solidities LDR materials, separates and decontaminates metals, and separates and decontaninates/encapsulates lead. Proposed outputs include packaged TRUW for a repository, packaged Li:W for LDR, clean lead, and clean stack gas.

The Metal Decontamination Subsystem (S-EG-1) is shown in Figures A-9 and A-10 sorts into TRUW metals, LLW metals, liquid/residue, and clean water. Figure A-10 also shows the general arrangement for the waste receiving, processing and packaging facility. 


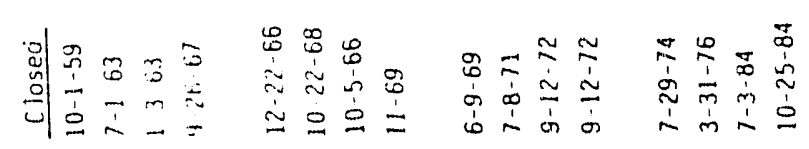

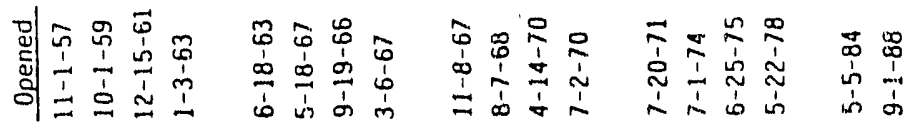

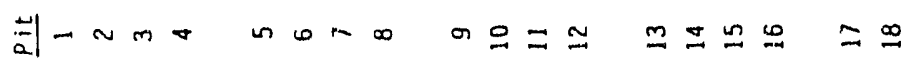

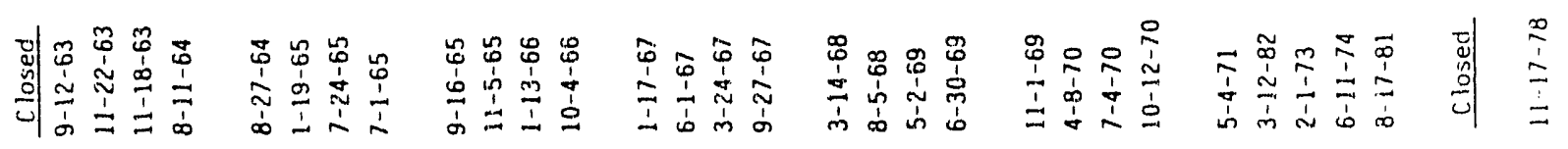

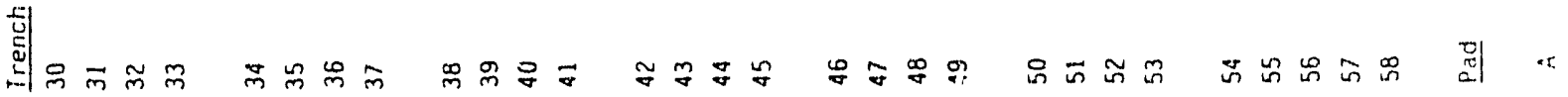

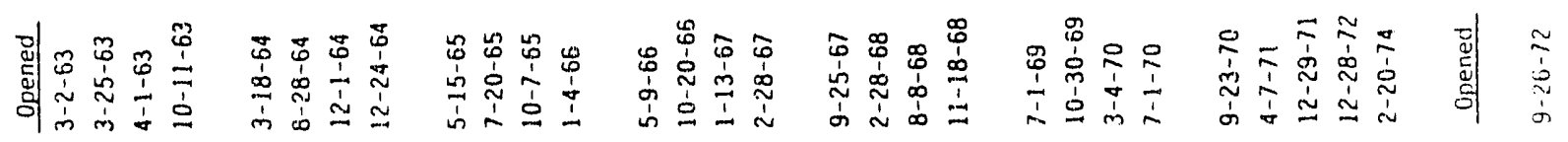

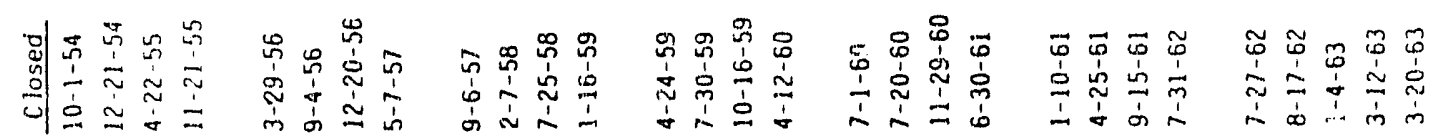

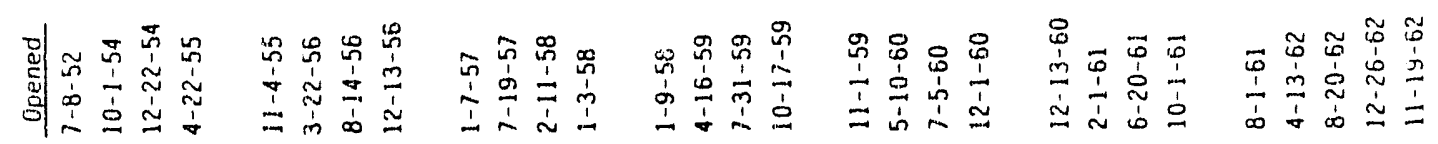

$\frac{5}{4}$

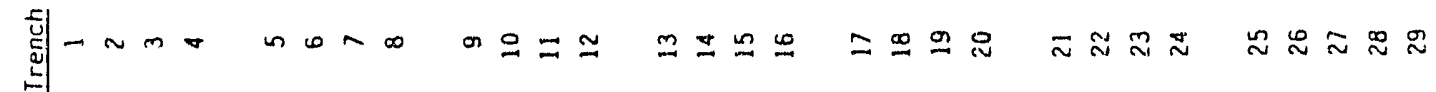




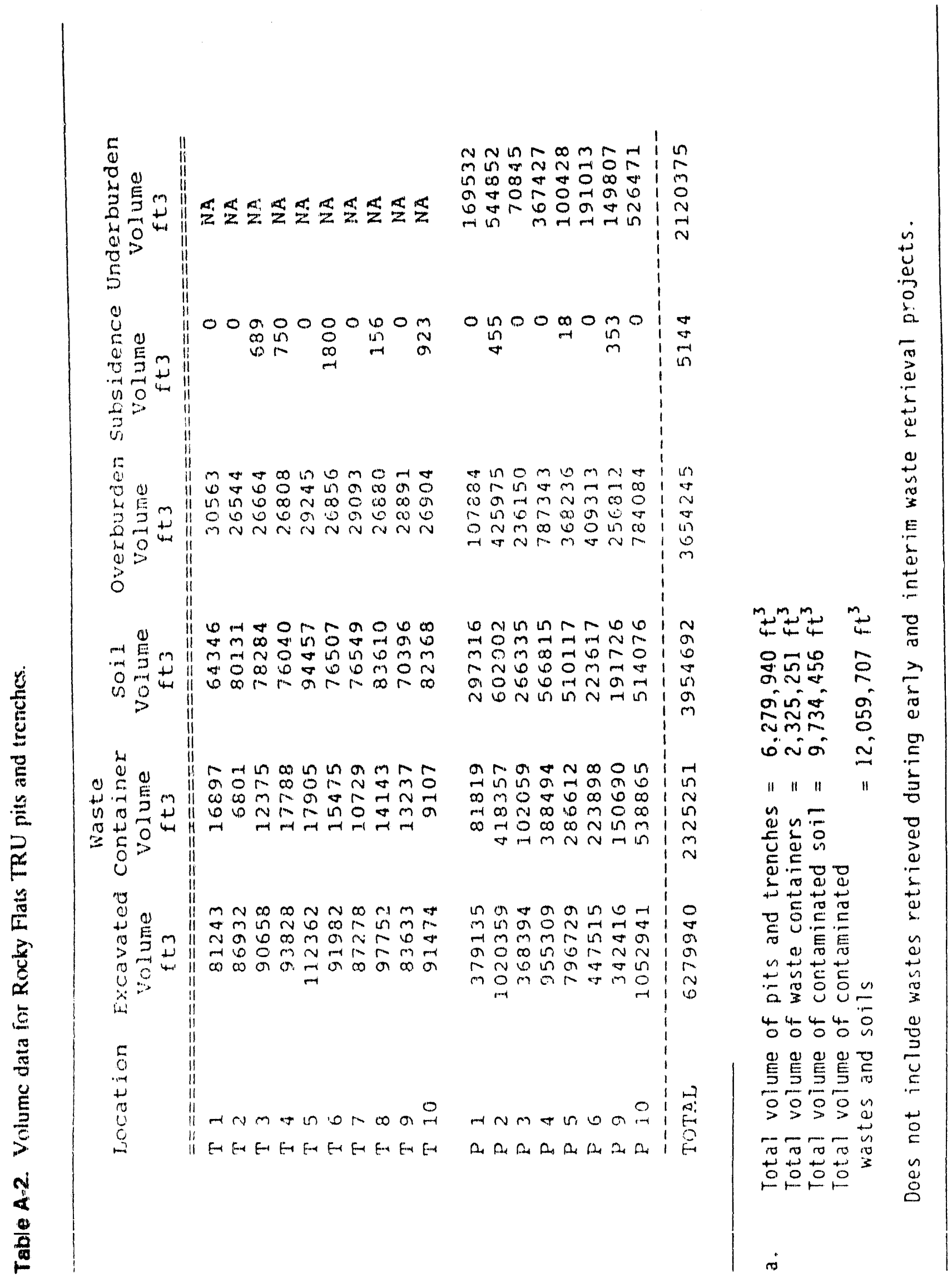




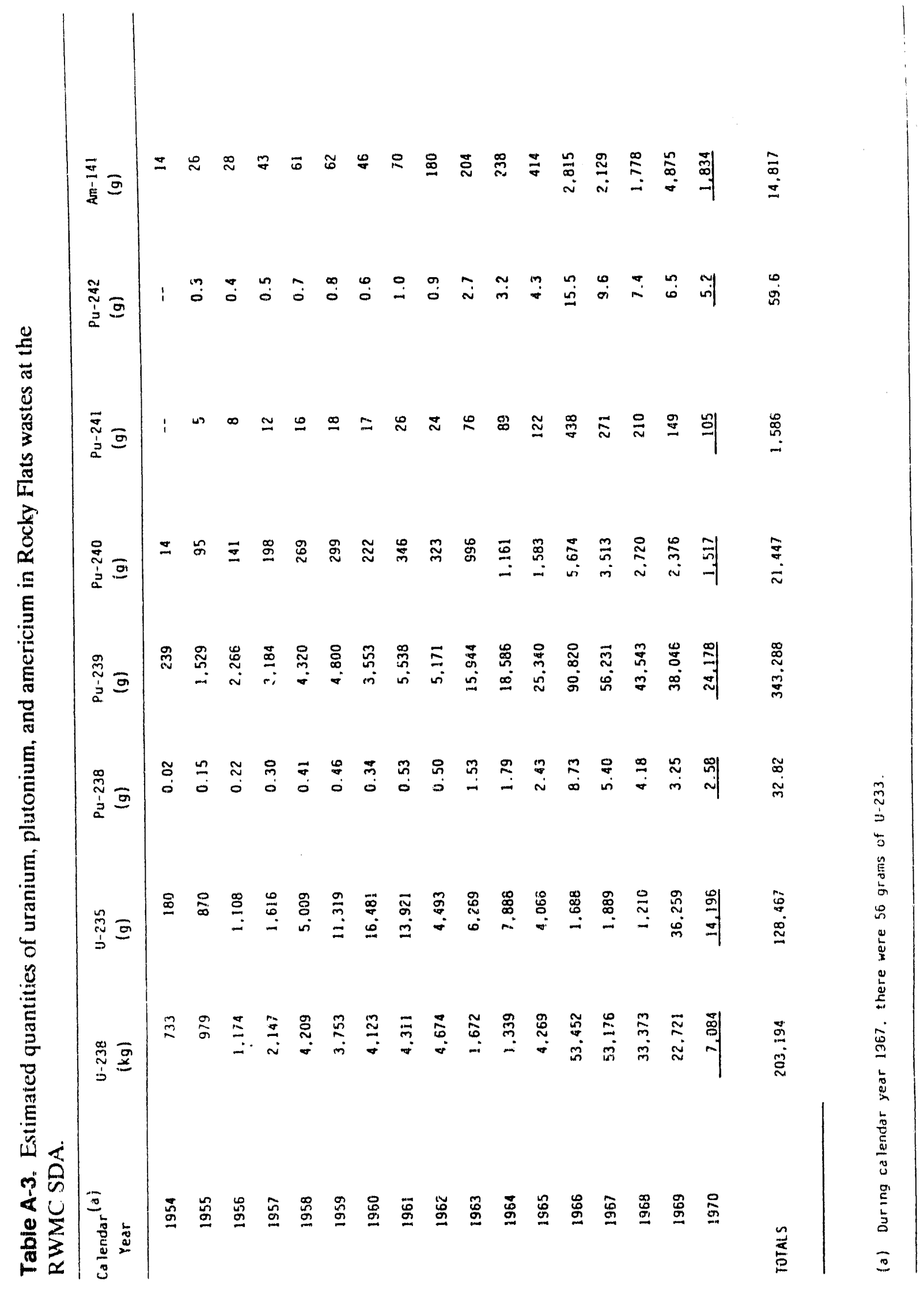


Table A-4. Waste container types, numbers, and total volumes for selected trenches at the SDA.

\begin{tabular}{|c|c|c|c|c|}
\hline Trencl & No. & Container Type & No. of Containers. & $\begin{array}{l}\text { Volume of } \\
\text { Containers } \\
\left(\mathrm{ft}^{3}\right)\end{array}$ \\
\hline 1 & & $\begin{array}{l}\text { Drums } \\
\text { Other }\end{array}$ & $\begin{array}{r}3,376 \\
1 \\
3,377\end{array}$ & $\begin{array}{r}16,747 \\
150 \\
16,897\end{array}$ \\
\hline 2 & & $\begin{array}{l}\text { Drums } \\
\text { Wooden Boxes }\end{array}$ & $\begin{array}{r}1,045 \\
4 \\
1,049\end{array}$ & $\begin{array}{r}6,761 \\
40 \\
6,801\end{array}$ \\
\hline 3 & & $\begin{array}{l}\text { Drums } \\
\text { Wooden Boxes } \\
\text { Cardboard Boxes }\end{array}$ & $\begin{array}{r}1,242 \\
6 \\
1,423 \\
2,671\end{array}$ & $\begin{array}{r}8,655 \\
162 \\
7,115 \\
15,932\end{array}$ \\
\hline 4 & & $\begin{array}{l}\text { Drums } \\
\text { Wooden Boxes }\end{array}$ & $\begin{array}{r}2,416 \\
1 \\
2,417\end{array}$ & $\begin{array}{r}17,761 \\
27 \\
17,788\end{array}$ \\
\hline 5 & & Drums & $\frac{2,541}{2,541}$ & $\frac{18,176}{18,176}$ \\
\hline 6 & & $\begin{array}{l}\text { Drums } \\
\text { Wooden boxes }\end{array}$ & $\begin{array}{r}2,283 \\
1 \\
2,284\end{array}$ & $\begin{array}{r}15,462 \\
13 \\
15,475\end{array}$ \\
\hline 7 & & Drums & $\frac{1,497}{1,497}$ & $\frac{10,729}{10,729}$ \\
\hline 8 & & $\begin{array}{l}\text { Drums } \\
\text { Cardboard boxes }\end{array}$ & $\begin{array}{r}1,654 \\
793 \\
2,447\end{array}$ & $\begin{array}{r}12,160 \\
3,965 \\
16,125\end{array}$ \\
\hline 9 & & $\begin{array}{l}\text { Drums } \\
\text { Wooden boxes } \\
\text { Cardboard box }\end{array}$ & $\begin{array}{r}1,769 \\
1 \\
2 \\
1,772\end{array}$ & $\begin{array}{r}13,008 \\
224 \\
10 \\
13,242\end{array}$ \\
\hline 10 & & $\begin{array}{l}\text { Steel drums } \\
\text { Cardboard boxes }\end{array}$ & $\begin{array}{r}1,236 \\
7 \\
1,243\end{array}$ & $\begin{array}{r}9,089 \\
\frac{35}{9,124}\end{array}$ \\
\hline a. & \multicolumn{4}{|c|}{$\begin{array}{l}\text { The stored waste in Trenches } 1-10 \text { consisted mainly of cardboard boxes } \\
\text { from the INEL on-site generators. Intermixed with the on-site boxes were } \\
\text { steel drums, wooden boxes, plastic bags, and loose waste. Some Rocky } \\
\text { Flats waste is a? } 1 \text { intermixed. Yalucs roflect the retrieved waste } \\
\text { removed. }\end{array}$} \\
\hline
\end{tabular}


Table A-5. Waste container types, numbers and total volumes for selected pits at the SDA.

\begin{tabular}{|c|c|c|c|}
\hline Pit No. & Container Type & No. of Containers & $\begin{array}{c}\text { Volume of } \\
\text { Containers }\left(\mathrm{ft}^{3}\right)\end{array}$ \\
\hline 1 & $\begin{array}{l}\text { Drums } \\
\text { Wooden Boxes } \\
\text { Cardboard Boxes } \\
\text { Other }\end{array}$ & $\begin{array}{r}8,285 \\
152 \\
2,173 \\
\quad \quad 2 \\
10,612\end{array}$ & $\begin{array}{r}60,917 \\
8,001 \\
12,869 \\
32 \\
81,819\end{array}$ \\
\hline 2 & $\begin{array}{l}\text { Drums } \\
\text { Wooden Boxes } \\
\text { Cardboard Boxes } \\
\text { Others }\end{array}$ & $\begin{array}{r}34,480 \\
1,048 \\
3,547 \\
443 \\
39,518\end{array}$ & $\begin{array}{r}252,077 \\
75,728 \\
17,960 \\
72,592 \\
418,357\end{array}$ \\
\hline 3 & $\begin{array}{l}\text { Drums } \\
\text { Wooden Boxes } \\
\text { Cardboard Boxes } \\
\text { Other }\end{array}$ & $\begin{array}{r}6,684 \\
201 \\
3,309 \\
62 \\
10,256\end{array}$ & $\begin{array}{l}48,961 \\
10,565 \\
30,774 \\
11,759 \\
102,059\end{array}$ \\
\hline 4 & $\begin{array}{l}\text { Drums } \\
\text { Wooden Boxes } \\
\text { Cardboard Boxes } \\
\text { Other }\end{array}$ & $\begin{array}{r}31,467 \\
624 \\
2,020 \\
268 \\
34,379\end{array}$ & $\begin{array}{r}231,330 \\
68,060 \\
16,617 \\
72,487 \\
388,494\end{array}$ \\
\hline 5 & $\begin{array}{l}\text { Drums } \\
\text { Wooden Boxes } \\
\text { Cardboard Boxes } \\
\text { Other }\end{array}$ & $\begin{array}{r}19,652 \\
919 \\
970 \\
102 \\
21,643\end{array}$ & $\begin{array}{r}144,355 \\
110,831 \\
7,773 \\
23,653 \\
286,612\end{array}$ \\
\hline 6 & $\begin{array}{l}\text { Drums } \\
\text { Wooden Boxes } \\
\text { Cardboard Boxes } \\
\text { Other }\end{array}$ & $\begin{array}{r}13,912 \\
590 \\
3,523 \\
36 \\
18,061\end{array}$ & $\begin{array}{r}102,272 \\
73,918 \\
41,242 \\
6,466 \\
223,898\end{array}$ \\
\hline 9 & $\begin{array}{l}\text { Drums } \\
\text { Wooden Boxes } \\
\text { Cardboard Boxes } \\
\text { Other }\end{array}$ & $\begin{array}{r}3,937 \\
520 \\
1,932 \\
72 \\
6,461\end{array}$ & $\begin{array}{r}28,942 \\
72,735 \\
29,571 \\
19,442 \\
150,690\end{array}$ \\
\hline 10 & $\begin{array}{l}\text { Drums } \\
\text { Wooden Boxes } \\
\text { Cardboard Boxes } \\
\text { Other }\end{array}$ & $\begin{array}{r}27,101 \\
2,311 \\
914 \\
295 \\
30,621\end{array}$ & $\begin{array}{r}189,857 \\
274,048 \\
11,830 \\
63,130 \\
538,865\end{array}$ \\
\hline
\end{tabular}


Table A-6. Special waste considerations buried in pits at the SDA.

\begin{tabular}{|c|c|}
\hline Pit No. & Comments \\
\hline 1 & $\begin{array}{l}\text { Pit reopened in October, } 1961 \text {, for disposal of some waste } \\
\text { from the SL-1 reactor incident. Waste contained } \\
\text { approximately } 120 \text { Curies of MFP. Highest radiation reading } \\
\text { recorded was } 10 \mathrm{R} / \mathrm{h} \text { at contact. This waste is probably } \\
1 \text { imited to the western end of the pit. }\end{array}$ \\
\hline 2 & $\begin{array}{l}\text { Large amounts of beta-gamma contaminated waste disposed with } \\
\text { the TRU drums and boxes. This waste includes reactor } \\
\text { shielding }(36,000 \text { lb), an aluminum heat exchanger }(20,000 \\
\left.\text { lb), drums with various contents, large (150 } \mathrm{ft}^{3}\right) \text { concrete } \\
\text { blocks contaminated with MFP, and other items. Also this } \\
\text { pit contains contaminated material from the cleanup of the } \\
\text { SL-1 incident. This pit was flooded in } 1962 \text {, prior to } \\
\text { closure. }\end{array}$ \\
\hline 3 & $\begin{array}{l}\text { NonTRU boxes from various on-site sources buried in this } \\
\text { pit. These boxes apparently contain MFP. Six boxes }(12,000 \\
\text { to } 14,000 \text { lb each) of intermediate-level waste (55-gal drum } \\
\text { centered in a box, and the box was then filled with concrete } \\
\text { shielding) buried at unknown locations in pit. SL-1 } \\
\text { incident cleanup waste also buried in this pit. }\end{array}$ \\
\hline 4 & $\begin{array}{l}\text { MFP wastes intermixed with TRU wastes; locations are not } \\
\text { clearly recorded (probably randomly dumped into the pit). } \\
\text { Non-TRU waste (containers, scrap lumber, concrete, } \\
\text { miscellaneous equipment, scrap metal, valves, and piping) } \\
\text { generally confined to the westernmost } 91 \mathrm{~m} \text { of the pit. }\end{array}$ \\
\hline 5 & $\begin{array}{l}\text { Burial location for some of the wastes may be in error. A } \\
\text { good possibility exists that some of the wastes may actually } \\
\text { be outside of recorded pit boundaries. }\end{array}$ \\
\hline 6 & $\begin{array}{l}\text { Drums and boxes were not segregated during burial. A large } \\
\text { number of boxes containing contaminated empty drums are } \\
\text { buried in this pit. }\end{array}$ \\
\hline 9 & $\begin{array}{l}\text { Drums and boxes were not segregated. A large number of } \\
\text { boxes containing contaminated empty drums are buried in pit. }\end{array}$ \\
\hline 10 & $\begin{array}{l}\text { Contains large number of boxes of contaminated empty drums, } \\
\text { but the number of drums per box is not known. This pit was } \\
\text { flooded in the spring of } 1969 \text {, before it was closed. }\end{array}$ \\
\hline
\end{tabular}


Table A-7. Volumes of organic wastes shipped from RFP to INEL.

\begin{tabular}{|c|c|c|c|c|c|}
\hline \multirow[b]{2}{*}{ Year } & \multirow[b]{2}{*}{$\begin{array}{c}\text { RWMC } \\
\text { Siatus } \\
\end{array}$} & \multirow[b]{2}{*}{$\begin{array}{l}\text { Number } \\
\text { of Drums }\end{array}$} & \multicolumn{3}{|c|}{ (Volumes in Gallons) } \\
\hline & & & $\begin{array}{c}\text { Texaco } \\
\text { Regal } \\
\text { Oil }\end{array}$ & $\begin{array}{c}\text { Carbon } \\
\text { Tetrachloride }\end{array}$ & $\begin{array}{c}\text { Other } \\
\text { Organic }\end{array}$ \\
\hline \begin{tabular}{l}
1966 \\
1967 \\
1968 \\
1969 \\
\multicolumn{1}{c}{ Total } \\
1970 \\
1971 \\
1972 \\
1973 \\
1974 \\
1975 \\
1976 \\
1977 \\
1978 \\
1979 \\
1980 \\
1981 \\
1982 \\
1983 \\
1984 \\
1985 \\
1986 \\
$1987^{\text {d }}$ \\
Total
\end{tabular} & $\begin{array}{l}\text { Buried } \\
\text { Buried } \\
\text { Buried } \\
\text { Buried } \\
\text { Buried } \\
\text { Stored } \\
\text { Stored } \\
\text { Stored } \\
\text { Stored } \\
\text { Stored } \\
\text { Stored } \\
\text { Stored } \\
\text { Stored } \\
\text { Stored } \\
\text { Stored } \\
\text { Stored } \\
\text { Stored } \\
\text { Stored } \\
\text { Stored } \\
\text { Stored } \\
\text { Stored } \\
\text { Stored } \\
\text { Stored } \\
\text { Stored }\end{array}$ & $\begin{array}{r}267 \\
5,518 \\
2,391 \\
533 \\
8,709 \\
1,092 \\
825 \\
953 \\
596 \\
572 \\
539 \\
361 \\
334 \\
471 \\
384 \\
422 \\
674 \\
480 \\
387 \\
276 \\
300 \\
463 \\
155 \\
9,284\end{array}$ & $\begin{array}{r}2,000^{b} \\
22,247 \\
10,771 \\
4,000^{b} \\
39,018 \\
2,528 \\
8,911 \\
11,322 \\
8,794 \\
9,158 \\
6,456 \\
4,548 \\
3,796 \\
3,388 \\
4,396 \\
5,095 \\
8,557 \\
6,736 \\
10,189 \\
8,646 \\
8,852 \\
8,617 \\
4,853 \\
124,842\end{array}$ & $\begin{array}{c}800^{b} \\
14,832 \\
7,181 \\
1,600^{b} \\
24,413 \\
1,685 \\
5,940 \\
7,548 \\
5,862 \\
6,106 \\
4,304 \\
3,032 \\
2,531 \\
2,259 \\
2,930 \\
3,396 \\
5,705 \\
4,491 \\
6,792 \\
5,764 \\
5,902 \\
5,744 \\
3,235 \\
83,226\end{array}$ & $\begin{array}{c}\text { No Record } \\
4,255 \\
18,313 \\
2,400^{b} \\
24,968 \\
35,135 \\
16,564 \\
10,771 \\
6,846 \\
5,356 \\
5,371 \\
4,179 \\
4,743 \\
\therefore ?, 431 \\
0,398 \\
7,925 \\
10,127 \\
7,670 \\
9,240 \\
120 \\
\ldots \ldots \\
\ldots \ldots \\
\ldots \ldots \\
142,876\end{array}$ \\
\hline
\end{tabular}

a. Mostly 1,1,1-trichloroethane, trichloroethylene, perchloroethylene, and used oil.

b. Data estimated.

c. In 1984, this category of organic wastes were processed separately and shipped to the Nevada Test Site as low-level wastes.

d. January to June 1987. 
Table A-8. Estimates of metal content in selected pits and trenches at the SDA.

\begin{tabular}{|c|c|c|c|}
\hline $\begin{array}{l}\text { Waste } \\
\text { Location }\end{array}$ & $\begin{array}{c}\text { Total Weight } \\
\text { of Waste } \\
(\mathrm{kg})\end{array}$ & $\begin{array}{c}\text { Maximum Metal } \\
\text { Weight } \\
(\mathrm{kg})\end{array}$ & $\begin{array}{c}\text { Minimum Metal } \\
\text { Weight } \\
(\mathrm{kg})\end{array}$ \\
\hline Pit 1 & 337,300 & 269,840 & 16,865 \\
\hline Pit 2 & $7,264,000$ & $5,811,200$ & 363,200 \\
\hline Pit 3 & 823,500 & 658,800 & 41,175 \\
\hline Pit 4 & $5,539,000$ & $4,431,200$ & 276,950 \\
\hline Pit 5 & $2,968,000$ & $2,374,400$ & 148,400 \\
\hline Pit 6 & $2,672,000$ & $2,137,600$ & 133,600 \\
\hline Pit 9 & $1,357,707$ & $1,086,166$ & 67,885 \\
\hline Pit 10 & $6,148,000$ & $4,918,400$ & $30 T, 400$ \\
\hline Trench 1 & 274,500 & 219,600 & 13,725 \\
\hline Trench 2 & 123,700 & 98,960 & 6,185 \\
\hline Trench 3 & 196,500 & 157,200 & 9,825 \\
\hline Trench 4 & 267,600 & 214,080 & 13,380 \\
\hline Trench 5 & 347,200 & 277,760 & 17,360 \\
\hline Trench 6 & 305,000 & 244,000 & 15,250 \\
\hline Trench 7 & 198,800 & 159,040 & 9,940 \\
\hline Trench 8 & 208,000 & 166,400 & 10,400 \\
\hline Trench 9 & 179,300 & 143,440 & 8,965 \\
\hline Trench 10 & 110,500 & 88,400 & 5,525 \\
\hline TOTAL & $27,962,900$ & $22,370,320$ & $1,398,145$ \\
\hline
\end{tabular}

a. Maximum metal weight was assumed to be $80 \%$ (worst-case scenario) of the total weight of the waste. Minimum metal weight was assumed to be $5 \%$ of the total weight of the waste. 


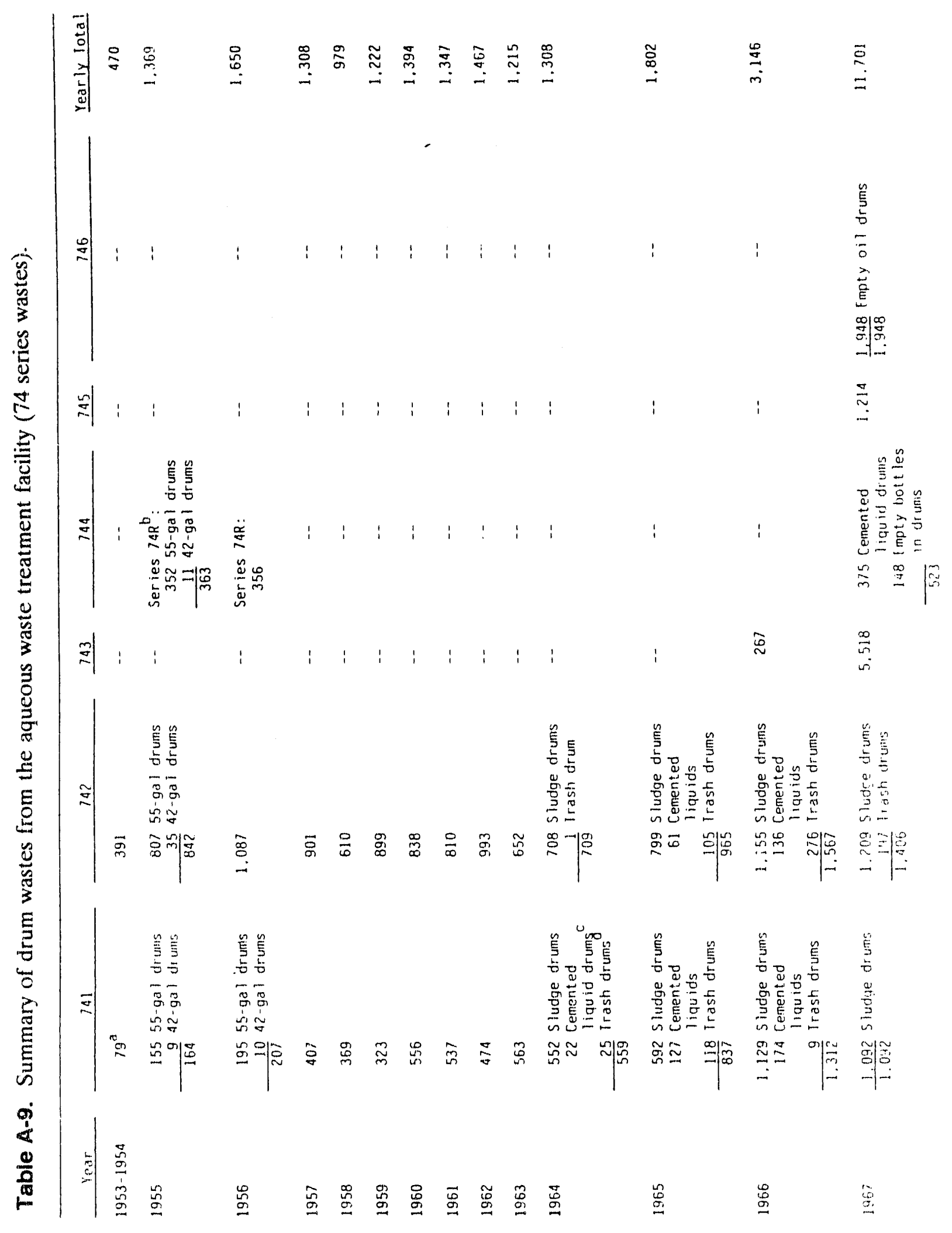




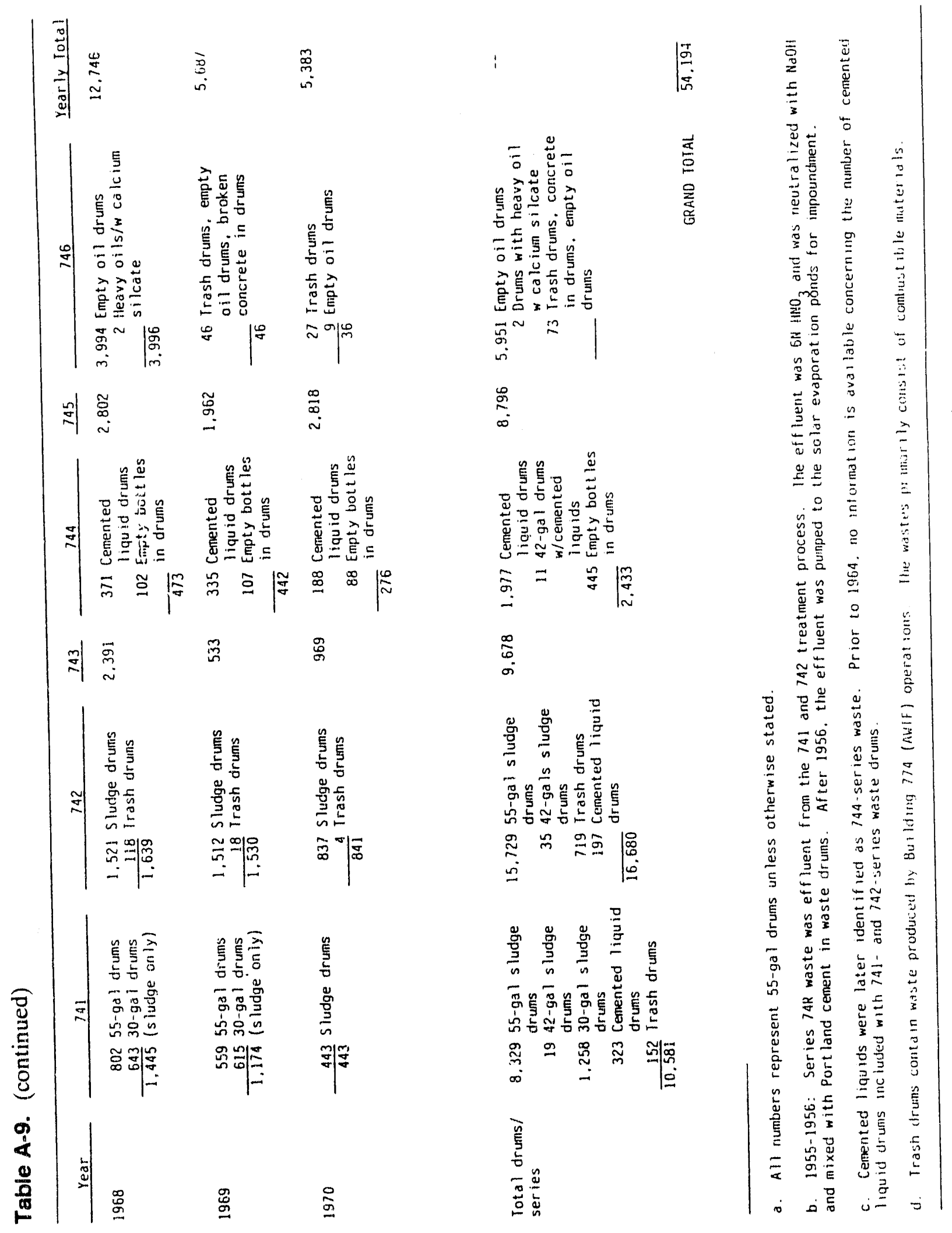


Table A-10. Weight and volume fractions of wastes stored at the RWMC.

\begin{tabular}{|c|c|c|c|c|c|}
\hline & Category & Codes & $\begin{array}{l}\text { Weight } \\
\text { Fraction }\end{array}$ & $\begin{array}{l}\text { Volume } \\
\text { Fraction }\end{array}$ & $\begin{array}{l}\text { Density } \\
\left(1 \mathrm{~b} / \mathrm{ft}^{3}\right)\end{array}$ \\
\hline & Combustibles & 40 & 0.201 & 0.42 & 17.73 \\
\hline & Sludge & 36 & 0.327 & 0.18 & 67.22 \\
\hline & Unknown/unclassifiable & 21 & 0.097 & 0.15 & 24.87 \\
\hline & Metals & 15 & 0.222 & 0.086 & 95.87 \\
\hline & Mixed waste & 22 & 0.0389 & 0.073 & 19.86 \\
\hline & $\begin{array}{l}\text { Concrete, brick, } \\
\text { particulates }\end{array}$ & 38 & 0.0791 & 0.045 & 65.70 \\
\hline & Nonmetals and glass & 18 & 0.0284 & 0.041 & 25.95 \\
\hline & Low level & 7 & 0.00389 & 0.005 & 31.81 \\
\hline & Remote handled & 2 & 0.000961 & 0.001 & 25.31 \\
\hline & NonTRU & 1 & 0.00133 & 0.001 & 47.87 \\
\hline & Salts & 11 & 0.000691 & 0.0007 & 39.37 \\
\hline ame & \multicolumn{5}{|c|}{$\begin{array}{l}\text { Weight and volume fractions of the buried TRU wastes are assumed to be } \\
\text { as that given for the stored TRU wastes. }\end{array}$} \\
\hline
\end{tabular}




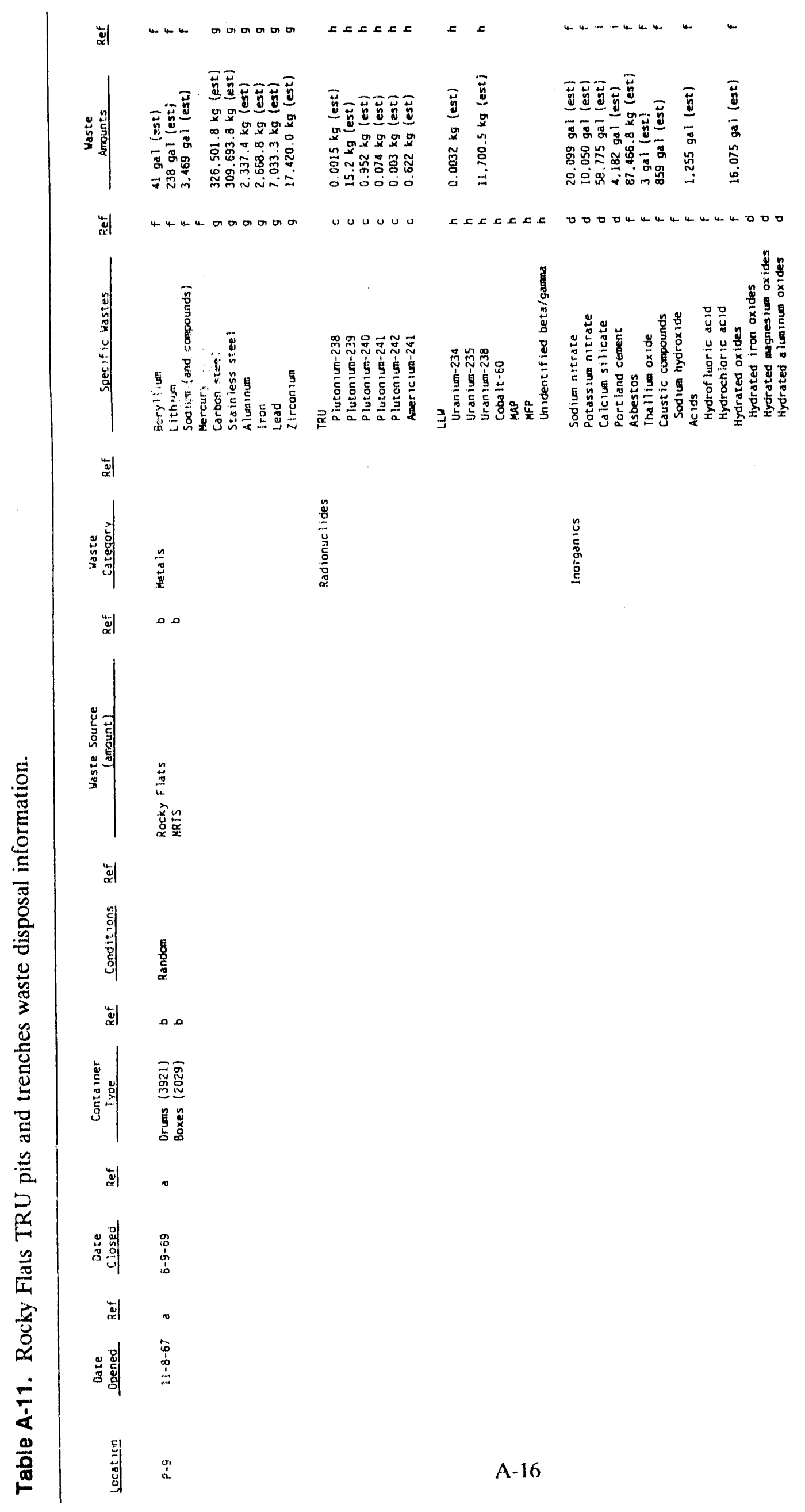




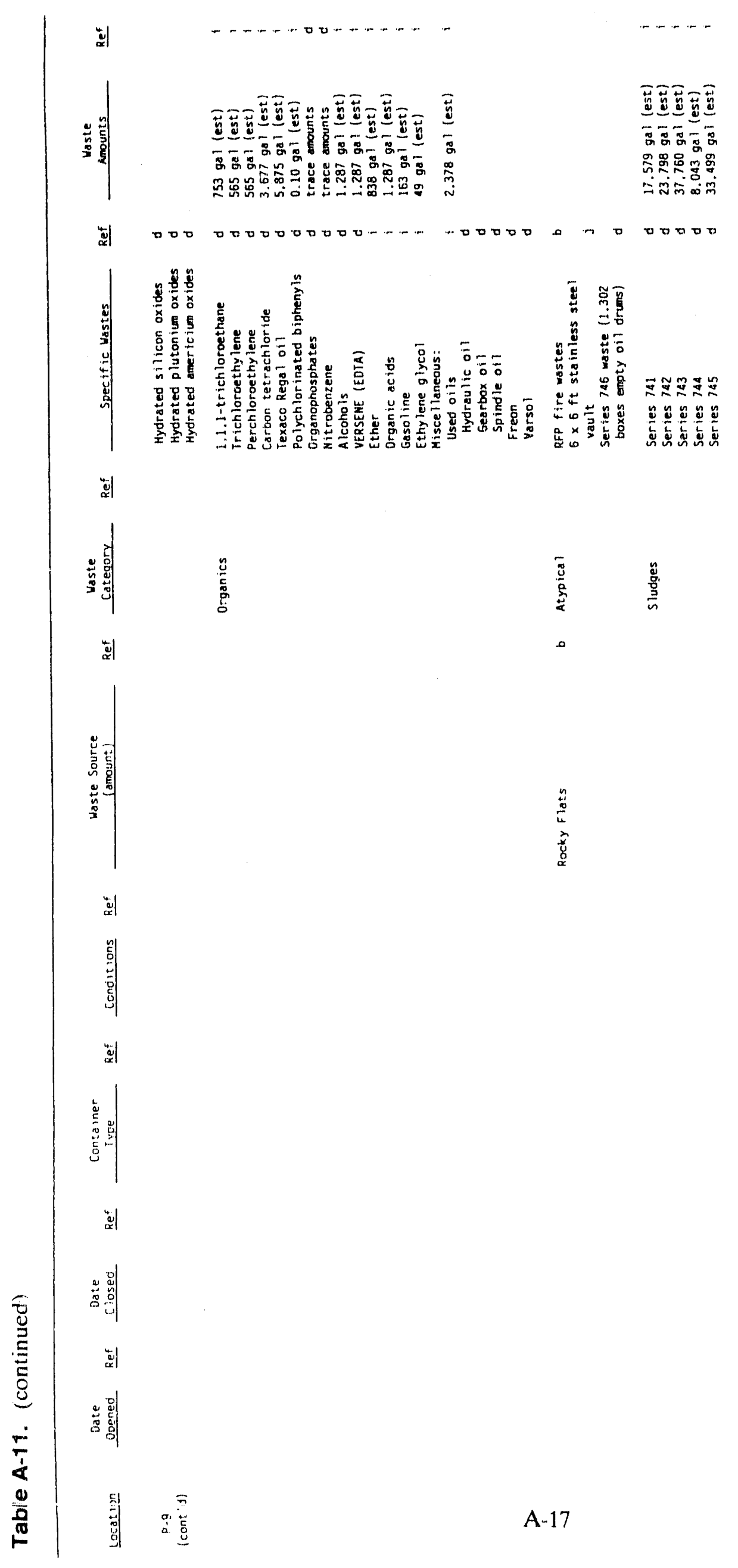




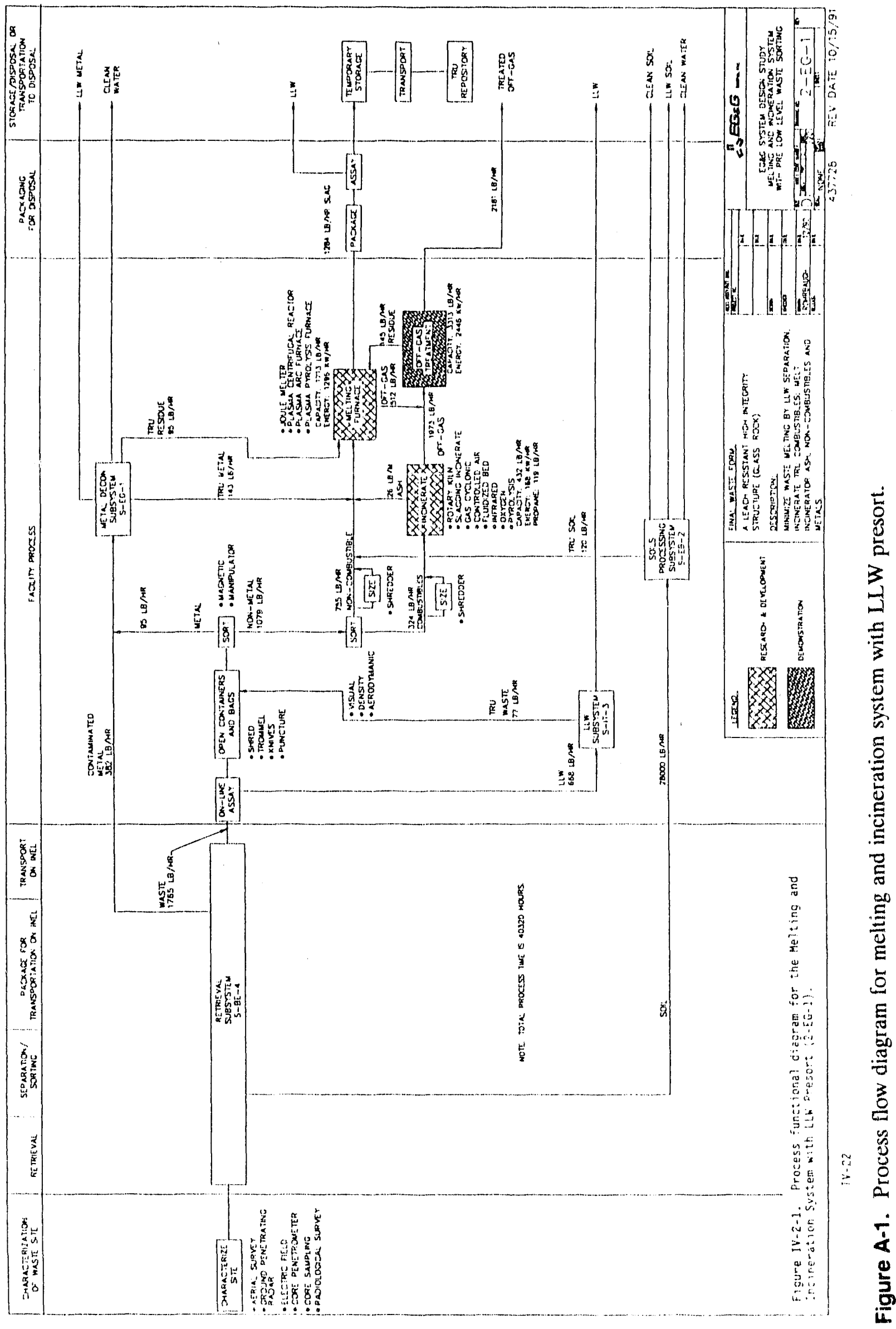




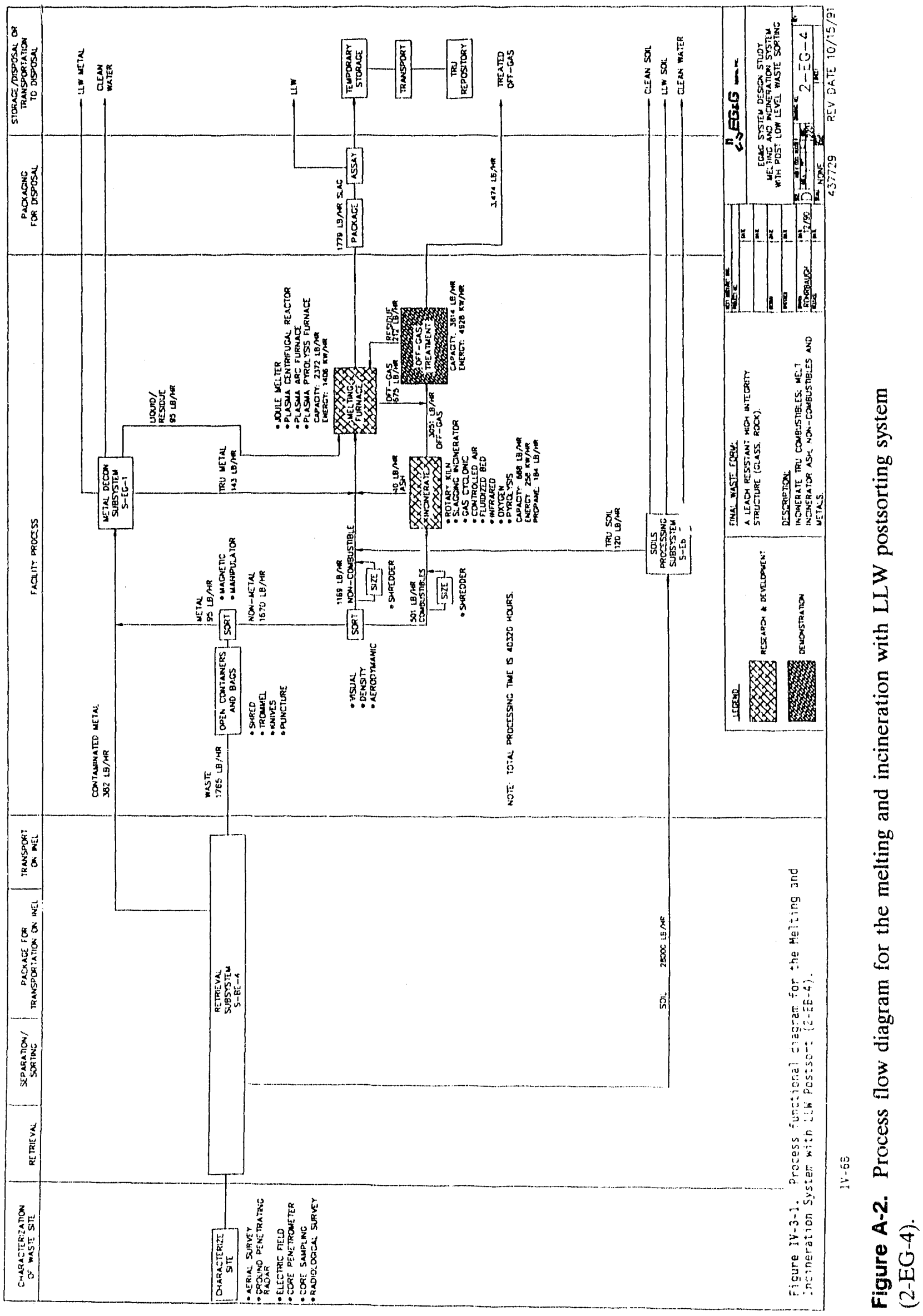




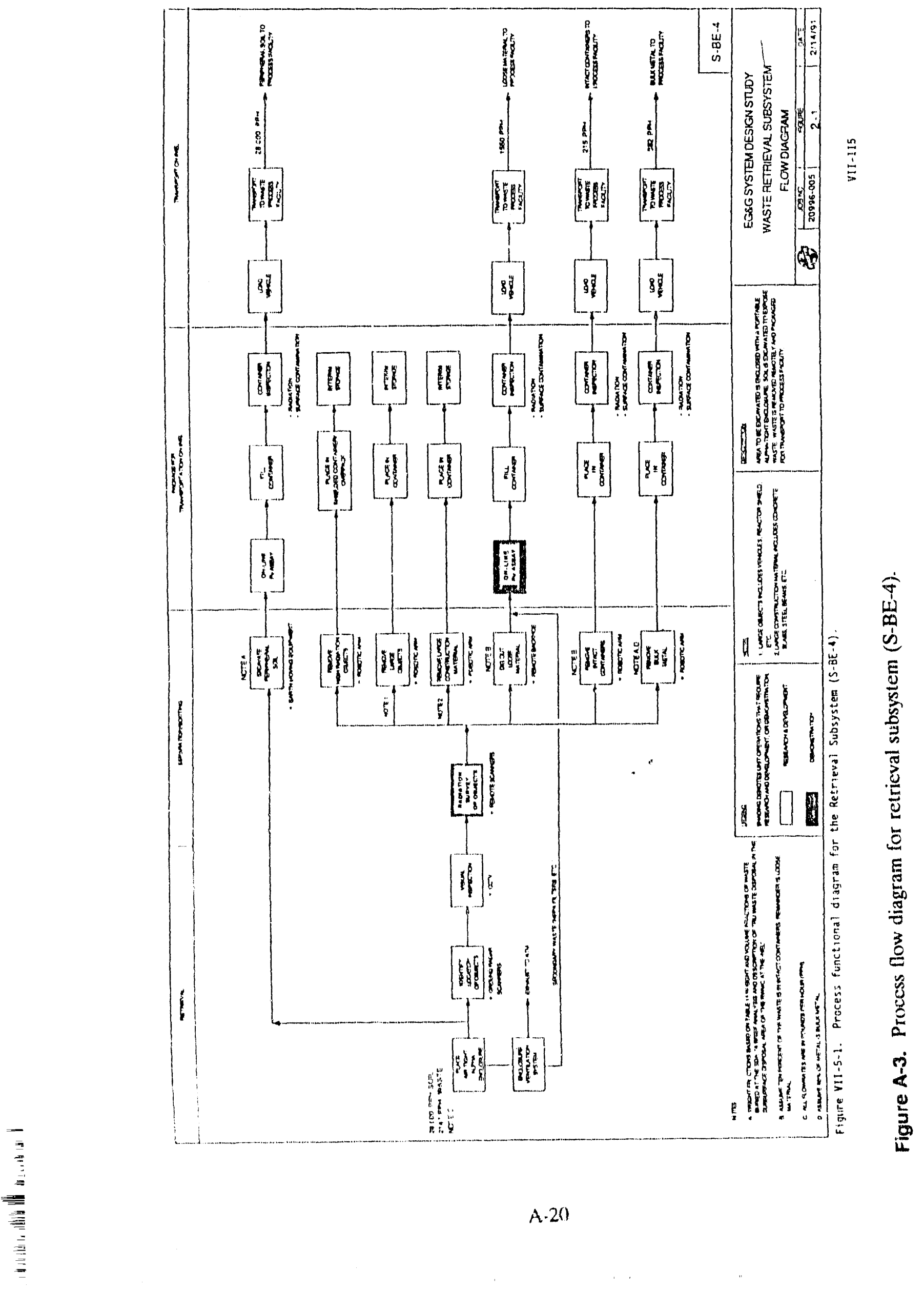



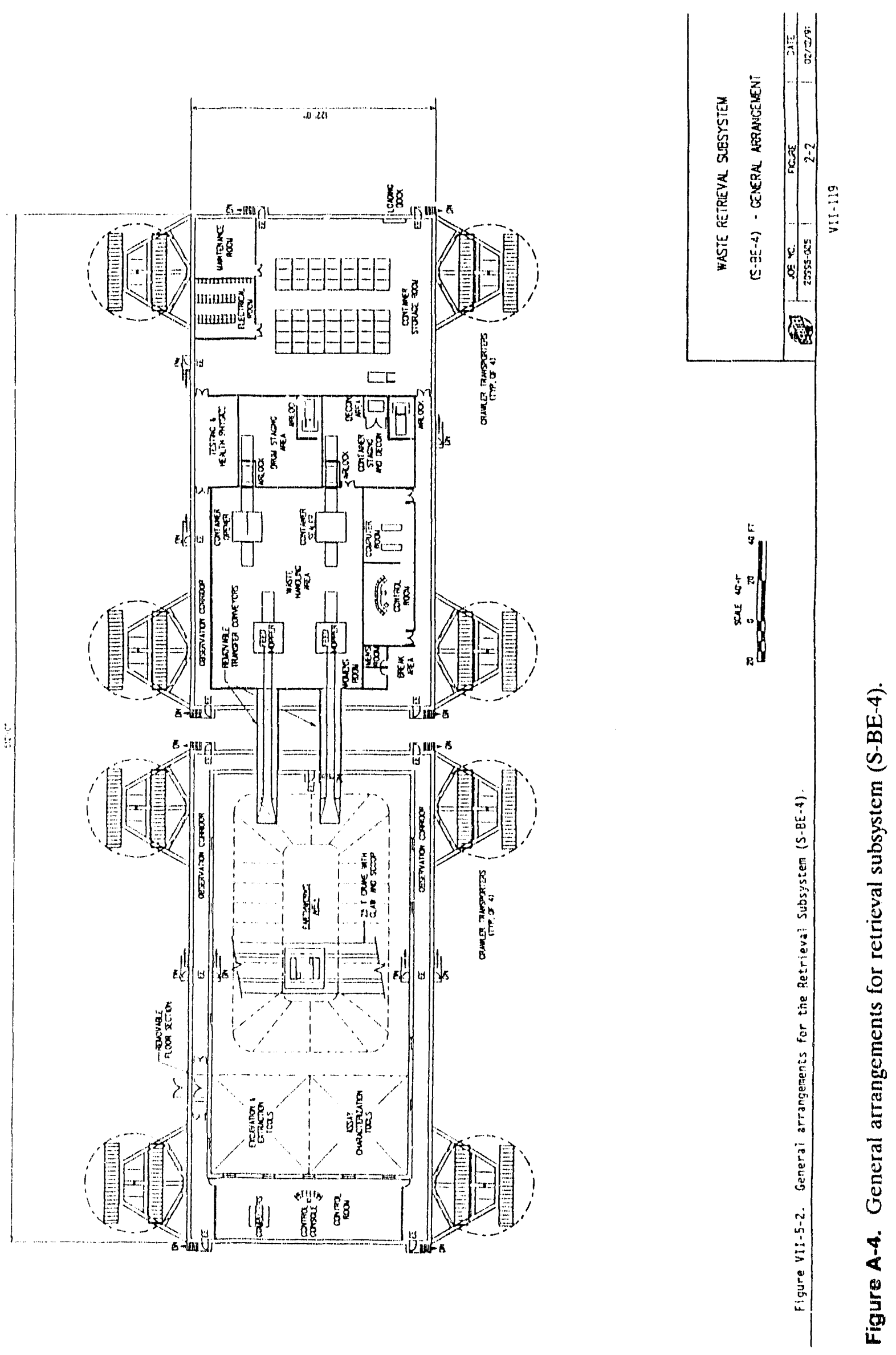


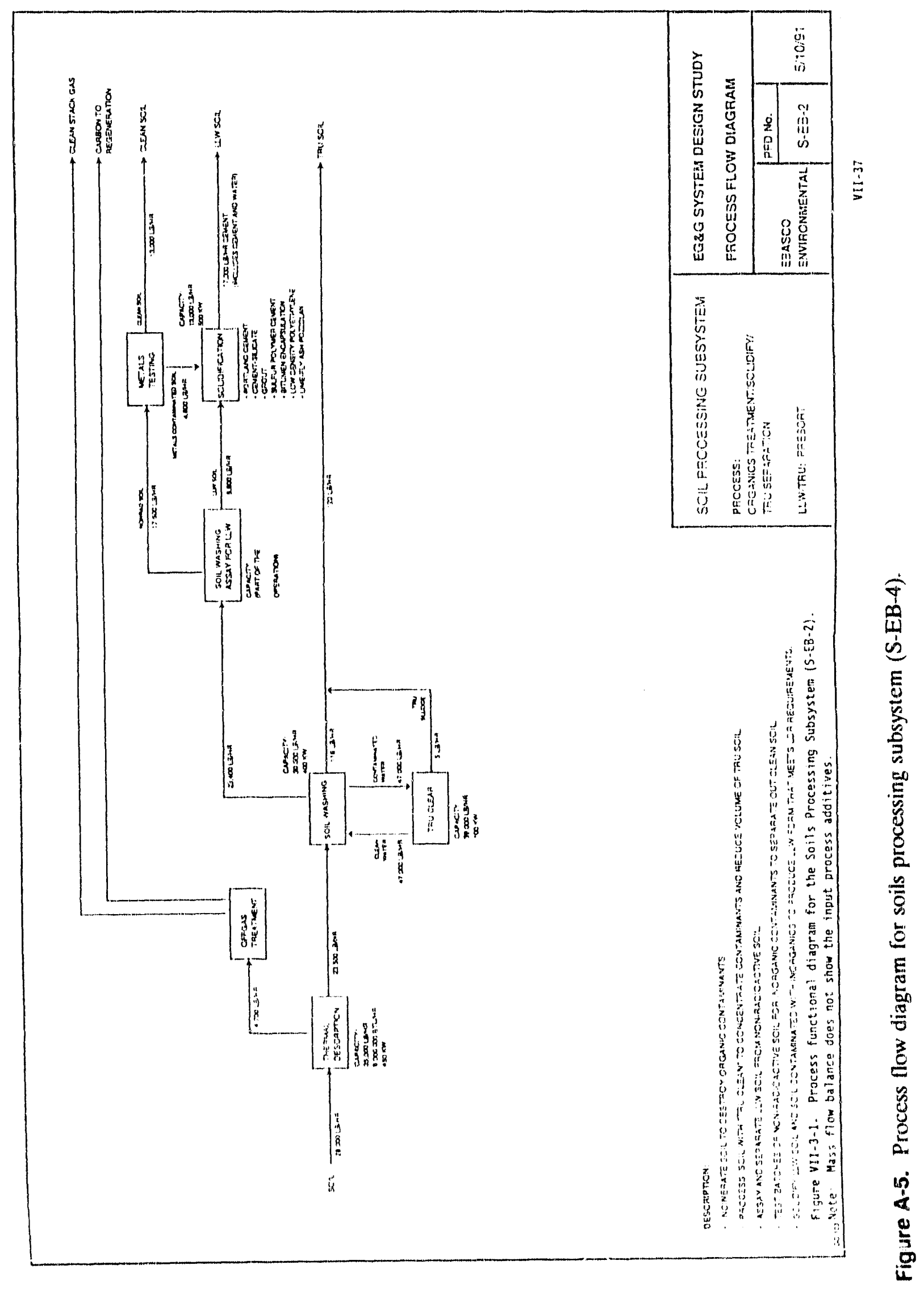




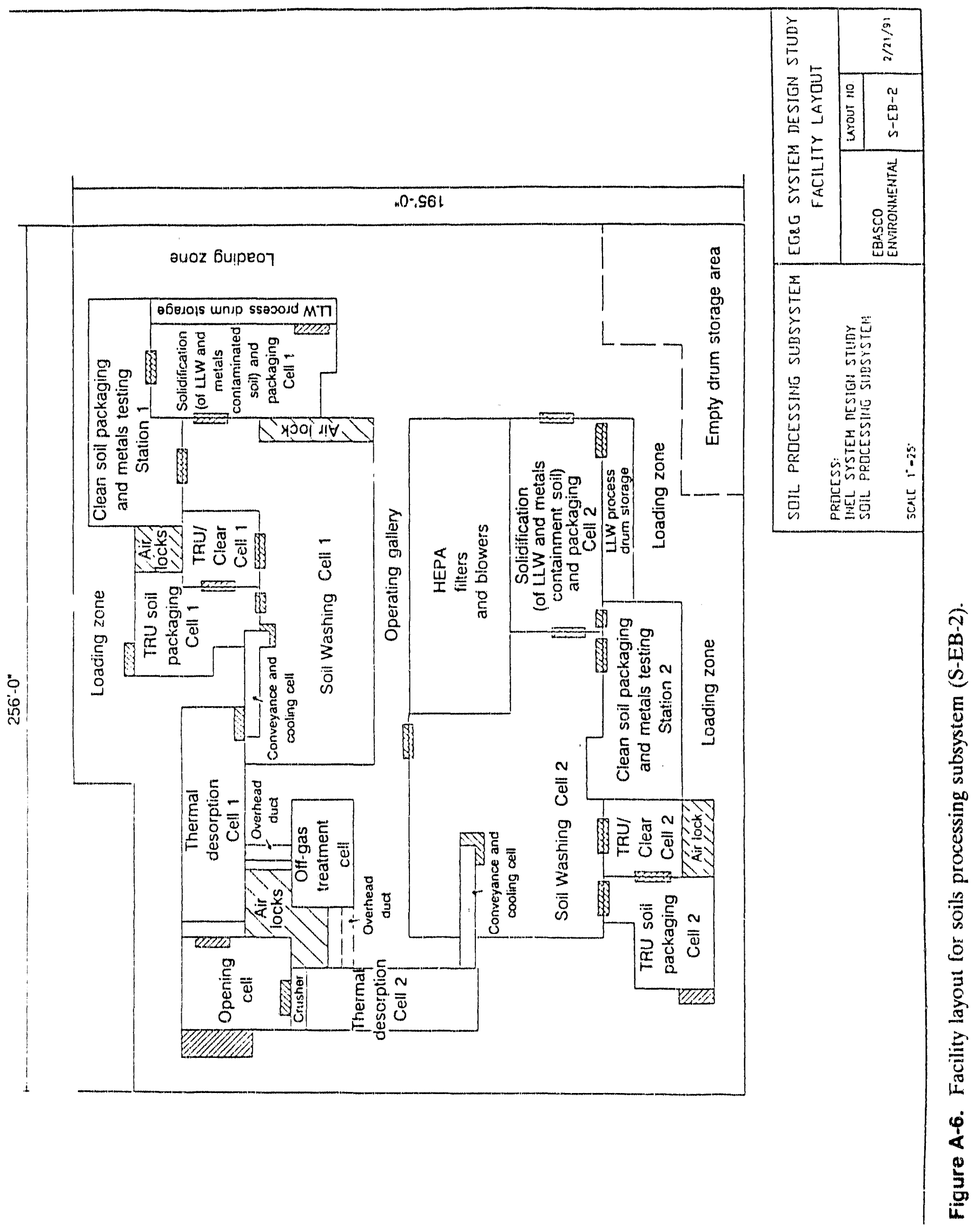




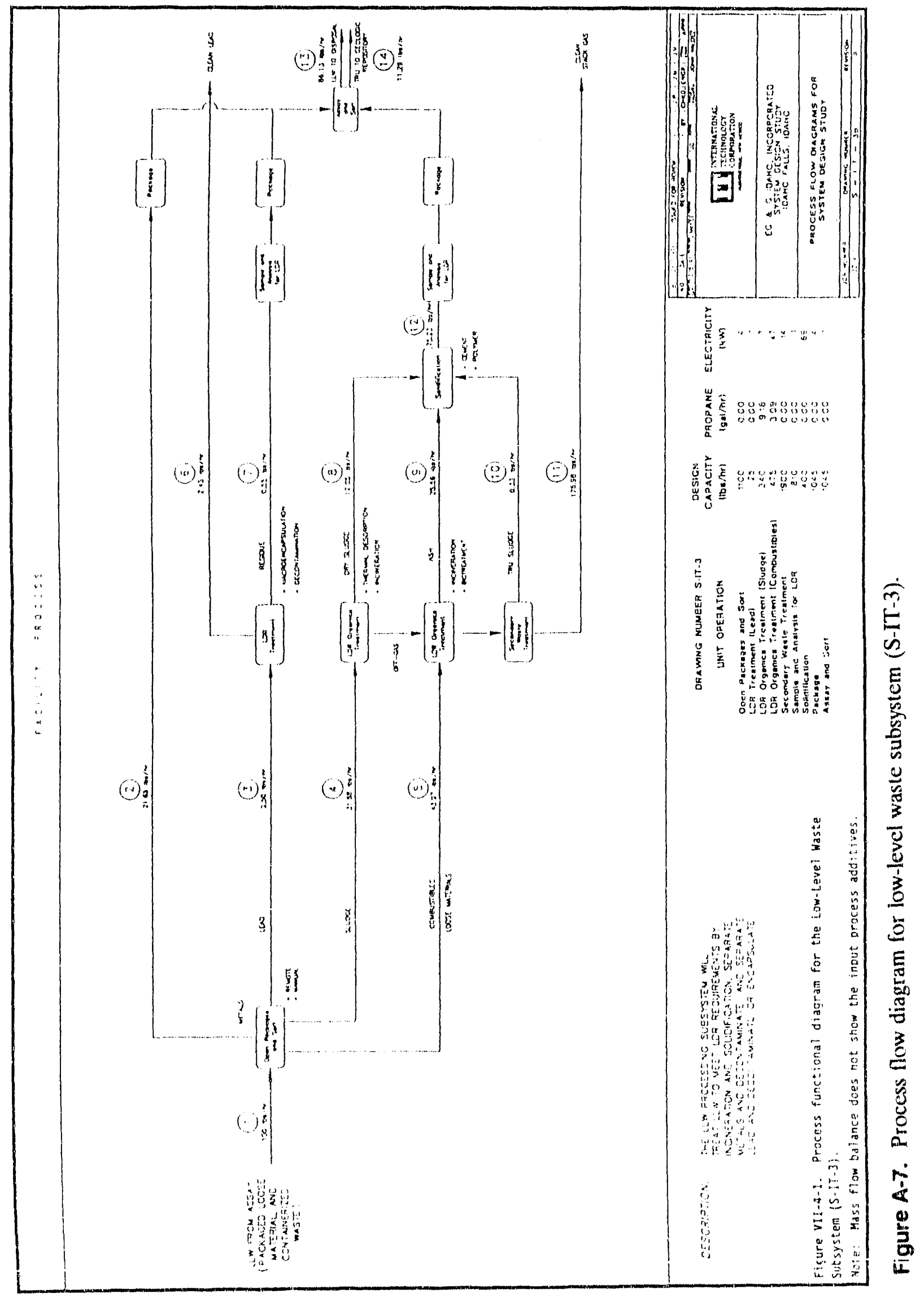




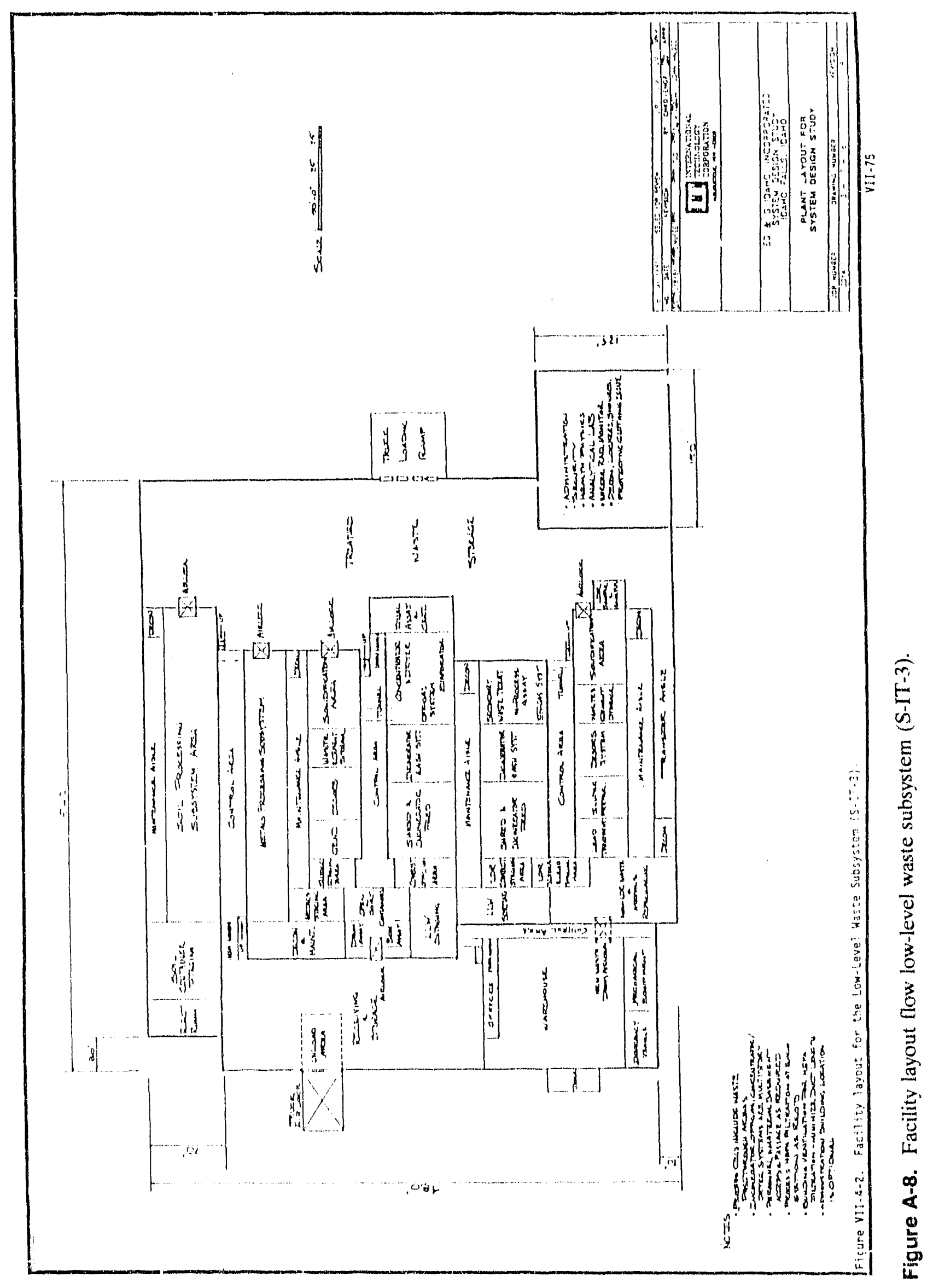




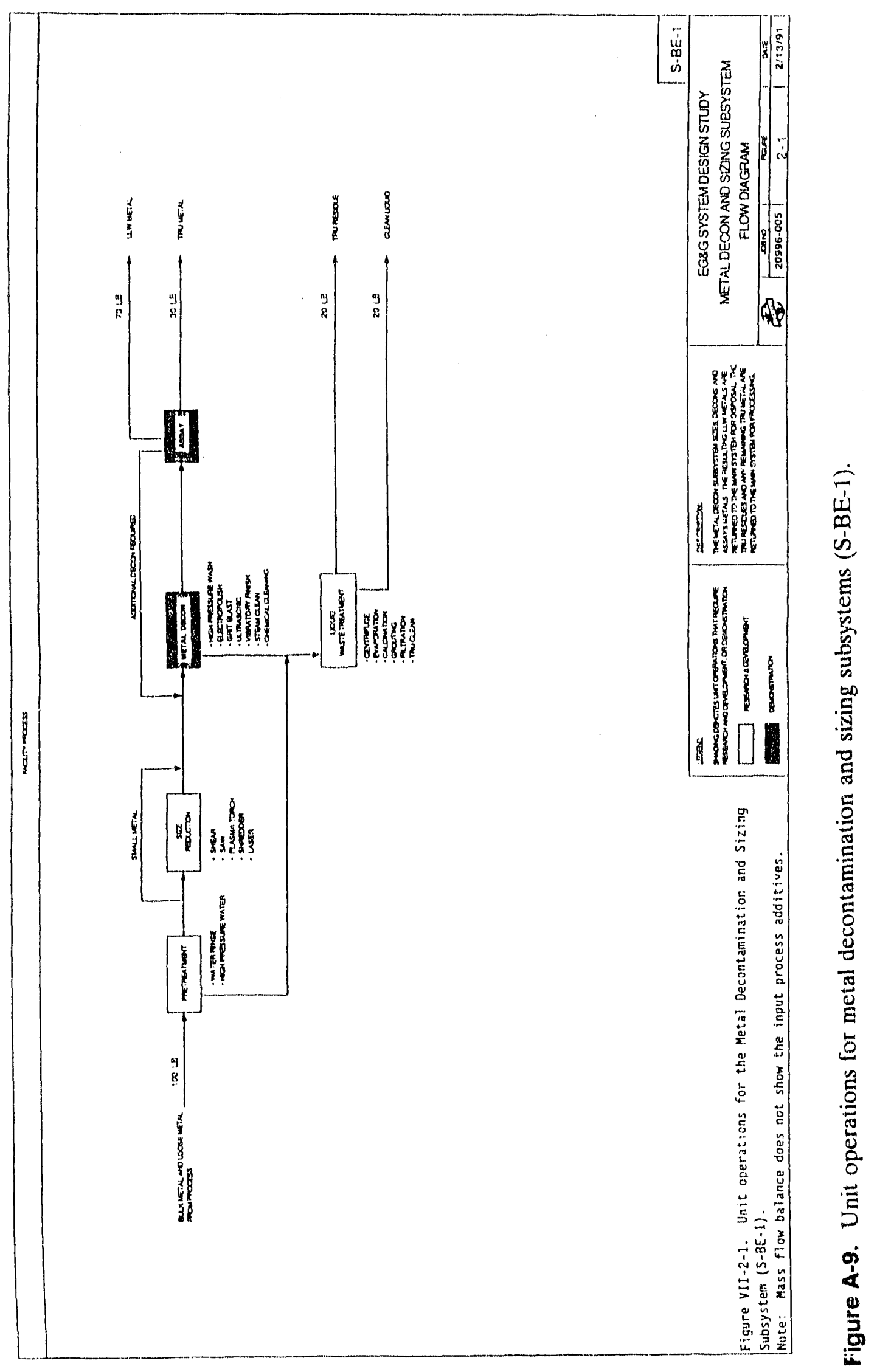

A. 26 


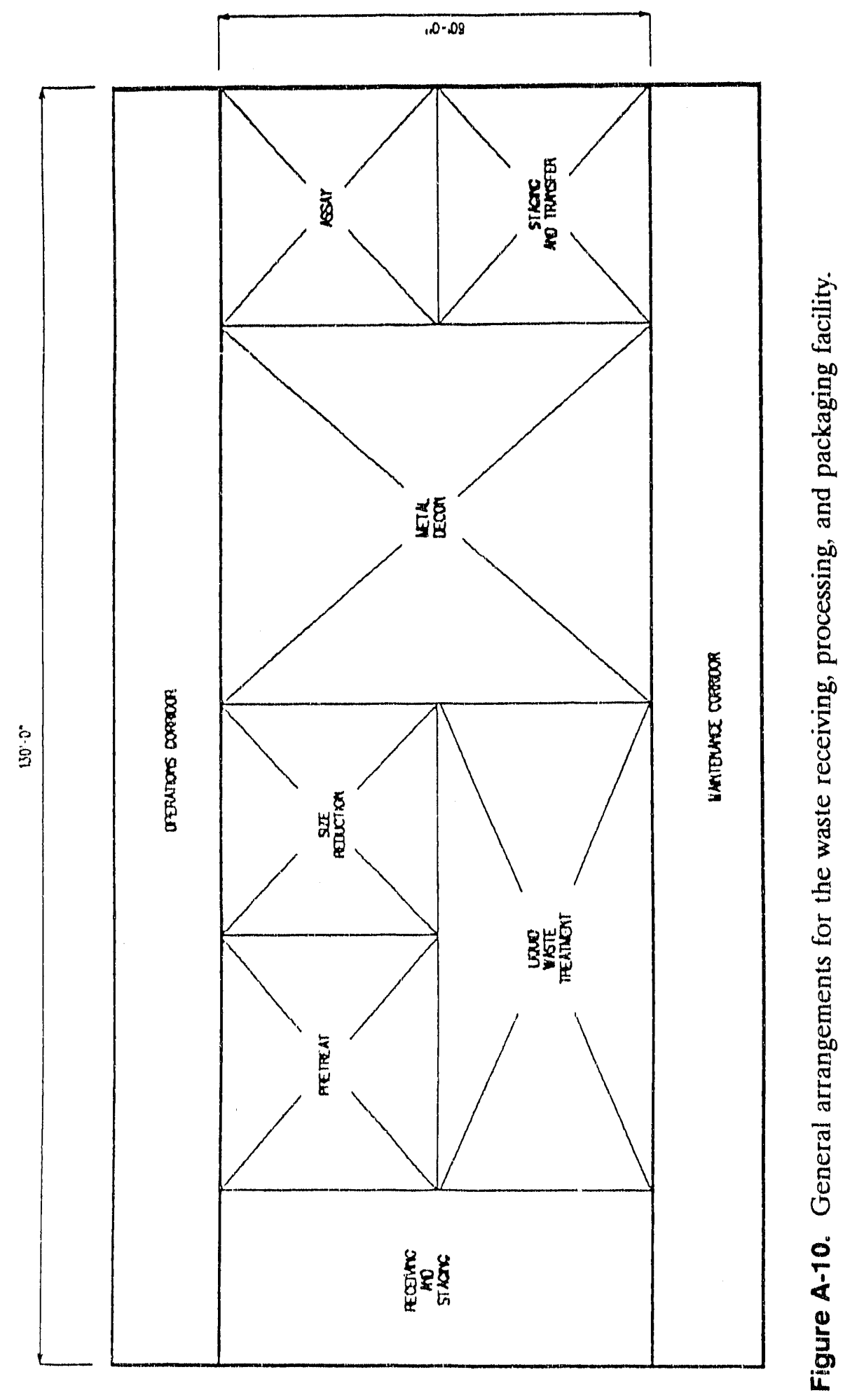




\section{REFERENCES}

1. M. J. Vigil, "Subsurface Disposal Area (SDA) Waste Identification," EGG-WM-8727, January 1990.

2. K. P. Guay, "Preparation of Soil Distribution in Trenches 1-10, and Pits 1-6, 9, and 10," BWPISV-011, in preparation.

3. D. H. Card, "History of Buried Transuranic Waste at INEL," WMP-77-3, March 1977.

4. D. E. Kudera, "Estimate of Rocky Flats Plant Organic Wastes Shipped to the RWMC," EG\&G Idaho, Inc., July 24, 1987.

5. E. C. Garcia, Thurmond, S. M., and Knight, J. L.., "Estimate of Metal Content of SDA," BWP-ISV-(0)5, January 24, 1989.

6. C. R. Edinborough, "Processing Criteria for TRU Removal from RWMC Stored Waste," ERDP 2802, 1990.

7. J. L. Mayberry, W. J. Quapp, F. Fcizollahi, J. C. Del Signore, and J. McFee, "Preliminary Systems Design Study Assessment Report," EGG-W'TD-9594, June 1991. 
Appendix B

Materials Characterization Methods 


\section{Appendix B}

\section{Materials Characterization Methods}

Materials characterization of the final waste form are discussed in detail for two aspects: (1) chemical, phase, and morphological analyses and (2) chemical, mechanical, and radiation durability tcsts.

\section{B.1 Chemical, Phase and Morphological Analyses}

The purpose of ehemical analysis is to determine the elemental eomposition of the final waste form as a whole, by regions, and of the phases in each region. The purpose of phase and morphological analyses is to identily the crystallographic phases of the bulk and in the regions. The molten slag is a complex elemental system which can form multiple phases while solidifying. During casting of the monolith, different regions of the cast will have different cooling rates and this will be reflected by the formation of heterogeneous phases in the monolith. Fast cooling outer regions of the monolithic bulk will vitrity to form glasses while the slow eooling inner regions will solidily into crystalline phases. Due to thermal diffusion effect, some glasses in the intermediate regions will partially devitrify to crystalline materials. The structure and elemental compesition of each region will reveal if any waste eomponents have segregated into less durable phases or migrated into interfaces between regions or the grain boundaries of crystalline phases.

The chemical, mechanical, and the irradiation lests supplemented by the material characte izations will provide the information on the overall durability of the monolithic final waste form. Any region in the monolith which shows strong departure from the statistical mean will be identified as a potential high release site.

Several analytical techniques are applicable to these types of evaluations. Each technique complements each other for complete analysis of the waste form products. Table B-1 summarics the available materials characterization techniques for the characterization of the linal waste form. These techniques will be discussed separately below.

\section{Inductively Coupled Plasma Atomic Emission Spectroscopy - ICP}

The ICP atomic emission spectroscopy can be applied to determine the overall elemental composition of different regions of the monolithic bulk material. The ICP will also provide the elemental composition to be used to determine normalized release in the durability tests. 
Table B-1. Summary table for linal waste form matcrial characterization.

\begin{tabular}{|c|c|}
\hline Techniques & Functions \\
\hline $\mathrm{ICP}$ & Elemental analysis in the bulk, regions and in leachates. \\
\hline $\mathrm{AA}$ & Elemental analysis in the bulk, regions and in leachates \\
\hline ICP-MS & Elemental and molecular functional group analysis \\
\hline SEM & $\begin{array}{l}\text { Morphology, particle sizes, phase identifieation, phase pereent, defects, } \\
\text { density determination, grain boundary and interlacial phases analysis (high } \\
\text { magnifications and resolutions) }\end{array}$ \\
\hline EDXS/WDXS & $\begin{array}{l}\text { Auxiliary analytical lunctions of the SEM } \\
\text { Semi-quantitative or quantitative elemental analysis, empirical chemical } \\
\text { compositions in phases }\end{array}$ \\
\hline X-ray Maps & $\begin{array}{l}\text { Auxiliary analytical lunctions of EDXS/WDXS } \\
\text { Detailed elemental distributions in phases }\end{array}$ \\
\hline OM & $\begin{array}{l}\text { Morphology, particle sizes, phase identification, phase percent, delects, } \\
\text { density determination, grain boundary and interfacial phases analysis (low } \\
\text { magnifications and resolutions) }\end{array}$ \\
\hline XRD & $\begin{array}{l}\text { Crystalline phase identification, phase amount determination and particle size } \\
\text { analysis }\end{array}$ \\
\hline STEM & $\begin{array}{l}\text { SEI mode - Scanning Electron Microscopy functions } \\
\text { TEI mode - Transmission Electron Microscopy functions, crystalline phases } \\
\text { identification by clectron diffraction, morphology and phase analysis by bright } \\
\text { field and dark field imaging }\end{array}$ \\
\hline XPS & $\begin{array}{l}\text { Elemental analysis, redox state information for the final waste form, } \\
\text { oxidation states and the bonding environment of the bonding elements, } \\
\text { provide information on leach surface revealing the preferential leach sites }\end{array}$ \\
\hline SAM & $\begin{array}{l}\text { Elemental analysis, local chemical bonding information, elemental } \\
\text { conecntration distribution by depth profiling, Auger electron maps reveal } \\
\text { elemental distributions, provide information on leach surface revealing the } \\
\text { preferential leach sites }\end{array}$ \\
\hline
\end{tabular}




\section{ICP-Mass Spectroscopy-ICP-MS}

This technique ean be used to augment the elemental analyses to yield mass fragment information of the molecular functional groups on the compound. Since the final waste form is an extremely complex system, ICP-MS may not be very useful in this regard.

\section{Atomic Absorption - AA}

The atomic absorption spectroscopy can be applied to determine the overall elemental composition of different regions of the monolithic bulk material. The AA will also provide the elemental composition to be used to determine normalized release in the durability tests.

\section{Scanning Electron Microscopy - SEM}

Scanning electron microscopy makes use of either secondary electrons or back scattered clectrons for image analysis. SEM can be applied to phase identification, morphology analysis, particle size analysis, phase pereent determination, defect formation, density determination, grain boundary and interfacial phase analysis, elc. The scanning electron microseope is a powerful instrument for detailed material ctaracterizations because it has much higher magnifications and resolutions than an optical microscope.

\section{Energy or Wavelength Dispersive X-ray Spectroscopy - EDXS/WDXS}

These Iwo are augmentational analytical techniques (o SEM. They provide semi-quantitative clemental analysis for the overall final waste form and for different regional composition. The approximate chemical formulation of phases can be inferred from semi-quantitative or quantitative analyses. X-ray mappings can provide detailed elemental distributions and segregations in all phases.

\section{Optical Microscopy - OM}

Optical microscopy (OM) can be used for phase identilication, morphology analysis, particle size analysis, phase pereent determination, defect analysis, density determination, grain boundary phase analysis, and interface segregation phenomena. The optical micrescepe is extremely easy to operate and is only good for quick preliminary analysis because of its low magnifications and resolutions. specimen preparations for electron and optical microscopes are moderately labor intensive.

\section{X-ray Diffraction Analysis - XRD}

XRD can be used to identify the structure of erystalline materials and their correspending phase amount in the sampling region, and for particle size analysis. When used in conjunction with the SEM, EDXS/WDXS, and $x$-ray mapping data, the specific crystalline phases that result from different cooling history in different regions of the monolith ean be determined. Knowledge of the crystalline morphology will help determine how waste components are incorporated into the linal waste form. allow for comparison to natural analogs, and assist in predicting its long-term behavior. 


\section{Scanning Transmission Electron Microscopy - STEM}

This instrumentation combines the lechniques of secondary electron imaging (SEI) and transmission electron imaging (TEI) for materials analyses. In the SEI mode it lunctions like a SEM. In the TEI mode it functions like a TEM and determines the crystal structure of all crystalline phases by electron diffraction. The morphology, defect structures, grain boundary phases (both crystalline and glasses), etc. can be identified by using both bright field and dark lield imaging techniques. Micro-micro electron diffraction techniques can be used to identily minute phases within a minor phase. STEM has higher magnifications, higher resolutions, and wider capabilities than an SEM but the sample preparation is extremely labor intensive. The instrumentation is particularly useful when grain boundary phases and interfacial segregations are studied.

\section{X-ray Photoelectron Spectroscopy - XPS}

Formerly known as ESCA, XPS uses a high energy x-ray beam for surface characterization. $X P S$ is useful in determining the redox state, the $\mathrm{Fe}^{2+} / \mathrm{Fe}^{3+}$ ratio in the final waste form. The redox state of the final waste form provides an indication to the valane state expected for the waste components and will help to predict in which phase the waste components will be partitioned in the final waste form. For example, if the condition in the slag melt is sufficiently reducing, transition elements, lead and eadmium may be partitioned to the bottom of the melter as a metal melt. XPS is also usclul for eomplete elemental analysis with the exception of hydrogen and helium. XPS can reveal the oxidation state, the bonding environment of an ion, and the elemental compositions in a phase. Since XPS is a surface analysis tool, it analyzes the top $10 \mathrm{~nm}$ layer of the material, it can provide information on a leached surface revealing the preferential leach sites.

\section{Scanning Auger Electron Microprobe - SAM}

This technique uses a highly focused high energy electron beam for surface and image analysis. Similar to XPS, it will perform elemental analysis and provide local chemical bonding information of clements in compounds. In situ sputtering can provide depth profiling of elements in the material. Auger electron mappings can be applied to reveal elemental distributions or segregation in the material. Similar to XPS, it can provide information on a leached surlace revealing the preferential kach sites.

\section{B.2 Chemical Durability Tests}

The following discussion on the chemical durability testing has been paraphrased from Bates' and can be applied to the evaluation of the final waste form by ex situ high temperature thermal processing since the final waste forms are very similar.

There are currently no specific durability specifications established for ISV/IEB final waste forms. The minimum expected lesting requirements will be those currently established for landfill disposal. Since September 1990, the Environmental Protection Agency (EPA) toxicity characterization keaching procedure (TCLP) ${ }^{2}$ has replaced the Extraction Procedure Toxicity Test (EPTox). Passing the test only classifies the ISV/IEB waste final form as satislying the RCRA criteria for EPA designated toxic metals keach characteristics. However, the TCLP test procedures neither address the radioactive components, provide an assessment for the keng-term durability, nor make a 
comparison to other highly durable linal waste forms or natural analogs. For each type of the durability tests, all major phases within the ISV/IEB tinal waste form should be lested, if possible. Where multiple phases cannot be separated, such as when devitrification produces an intimate mixture of different small grain erystalline phases, these multiphase mixtures should be tested as a single phase.

Sufficient replicates should be performed for each test sample to ensure the precision and accuracy of each test can be determined. The cost, amount of available samples, and the specilic durability tests will be the limiting factors to the number of replicates. Since no specific release requirements (except TCLP) have heen established for mixed and low-level TRU waste forms, no specific conlidence limits have been set.

\section{Reguluhong Required Tests - TCLP}

The required regulatory lest for the retention of waste eomponents is the TCLP tests. Waste is hazardous by delinition if it displays the characteristics of ignitability, reactivity, corrosiveness, and uxicity. Alter being formed at temperatures $>13(x)^{\circ} \mathrm{C}$, the ISV/IEB final waste forms are neither ignitable. reactive, or corrosive. The TCLP tests are designed to simulate the rainwater leaching process of ectain metals that a linal waste form would experience if disposed of in a sanitary landill. The maximum allowable concentration limits for the EPA designated metals is listed in Table B-2. No organics will be present in the ISV/IEB tinal waste form because of the exeedingly high processing temperatures. Therefore, no organic analysis will be required. The test consists of extracting $10(\mathrm{~g}$ of the powdered ISV/IEB linal waste form with $160(\%) \mathrm{g}$ of deionized water. Acetic acid is used to maintain the $\mathrm{pH}$ of the leaching fluid at $2.88 \pm 0.05$ or $4.93 \pm 0.05$. The procedure required the use of one of the pH values lor the leaching solution and temperatures between 20$)^{\circ} \mathrm{C}$ and $401^{\circ} \mathrm{C}$ lor a duration of 24 hours. The extract is then analyzed by ICP.

Table B-2. Maximum allowable concentrations lor EPA designaled metals.

\begin{tabular}{lc}
\hline Elements & Maximum Concentration (mg/licer) \\
\hline Arsenic (As) & 5.0 \\
Barium (Ba) & 100.0 \\
Cadmium (Cd) & 1.0 \\
Chromium (Cr) & 5.1 \\
Lead (Pb) & 5.0 \\
Mercury ( $\mathrm{Hg})$ & 0.2 \\
Selenium (So) & 1.0 \\
Silver (Ag) & 5.0 \\
\hline
\end{tabular}

\section{MCC.1 Shuic Lench Test}

The MCC-1 static leach lest ${ }^{3}$ measures the elemental mass loss of a glass sample as a lunetion (1) lime. For this test a glass monolith is suspended within a sealed tellon container. The surface 
area to volume ratio (surlace area of sample/volume of leachant, SA/V) is selected nominally $10 \mathrm{~m}^{-1}$. The leachant can be a synthetic ground water, a synthetic brine, or reagent water. The sealed container is maintained at $90^{\circ} \mathrm{C}$ for $3,7,14$, or 28 days. The test results are based on leachate elemental analysis from which the total concentrations of malerials leached from the sample are determined. The most commonly used test parameters are a SAV of $10 \mathrm{~m}^{-1}$ in deconized water at $97)^{\circ} \mathrm{C}$ for 28 days. These should be used for ISV/IEB testing to allow lor comparison with the large amount of data. One drawback for the MCC.-1 test is that it requires a small monolithic sample. Inhomogencities in the test samples. such as varying amounts of exposed phases, may result in inconsistent data. Therefore, MCC-I test procedure is more suitable for one-phase materials.

\section{MCC-3 Aginated Powder Leach Test}

The MCC-3 agitated powder leach test (see Reference 3) is similar to the MCC-1 test procedure. The only differenes are (a) specimens from the linal waste form are grounded to powders, and (b) powder and leachant are agitated by rotating the leflon container. The elemental concentrations from MCC-3 tests are estimated to be representative of the long-term extrapolation of $\mathrm{MCC}-1$ test results. This objective is achieved more rapidly in the $\mathrm{MCC}-3$ test because higher SAVV ratios are used than those for the MCC-1 lests. For cvaluation of ISV/IER final waste forms, the lest should be enducted with a SA $/ \mathrm{V}$ of $2000 \mathrm{~m}^{-1}$ in deionized water for 28 days (a large number of 7 to $\mathscr{C}$ ) day data also exist). Because of the higher SA/V used in the MCC-3 testing compared to that used for MCC-1 lesting. the keachants in the MCC-3 tests hecame saturated much sooner than the leachants in the MCC-1 lests. This saturation slows the dissolution process. Therefore, direct comparison of the normalized release values from the MCC-1 and $\mathrm{MCC}-3$ lests is not appropriate. Since MCC-3 tests use powdered samples, combination of glass and crystalline phases may be lested together.

To allow tor eomparison of leach test results from final waste forms with different compositions, results are given in terms of normalized elemental mass release for the MCC- 1 and MCC -3 tests and normalized concentration for the MCC 3 test. Normalized elemental mass releases can be calculated using the following equation:

$N R_{i}=m_{1} /\left(F_{i} \times S A\right)$

where

$$
\begin{aligned}
& N R_{i}=\text { normalized mass relcasc of element } \mathrm{i}\left(\mathrm{g} / \mathrm{m}^{2}\right) \\
& \mathrm{m}_{1}=\text { mass of element } \mathrm{i} \text { in leachate }(\mathrm{g}) \\
& \mathrm{F}_{1}=\text { fraction of element } \mathrm{i} \text { in linal waste form (dimensionless) } \\
& \mathrm{SA}=\text { surface area of monolith }\left(\mathrm{m}^{2}\right) \text {. }
\end{aligned}
$$

The following equation ean he used to calculate normalized elemental concentrations:

$N C_{i}=C_{1} / F_{1}$ 
where

$N C_{i}=$ normalized concentration of element $i\left(\mathrm{~g} / \mathrm{m}^{3}\right)$

$\mathrm{C}_{\mathrm{i}}=$ concentration of element $\mathrm{i}$ in leachate $\left(\mathrm{g} / \mathrm{m}^{3}\right)$

$F_{i}=$ fraction of element $i$ in final waste form (dimensionless).

\section{Forward Rate of Dissolution $\left(\mathrm{K}_{+}\right)$}

The lastest rate at which a glass/ecramic will dissolve is the forward rate of dissolution $\left(\mathrm{K}_{+}\right)^{4.56}$ This parameter has the most technical relevance when evaluating the dissolution behavior of different final waste glasses. The $\mathrm{K}_{+}$will indicate the durability of the final waste form under the condition of dynamic llow of unsaturated leachants (ground water).

To understand the forward rate, it is beneficial to discuss the following three different regimes typically observed in glass dissolution:

1. The time in which the glass first contacts a leachant and the glass dissolution rate is inhibited by any solubility eflects. In this period the leachant is highly unsaturated.

2. A transient regime where the increase in the concentrations of the dissolved components in the leachate impedes the dissolution rate through solubility effects.

3. A steady-state regime in which the dissolution rate is constant because the leachant has reached saturation i.c., reaching an equilibrium solubility product constant.

Typical release data can be plotled as elemental concentration in the leachate versus (SA/V)*t which shows three diflerent regions (see Figure B-1). The plot is rather sensitive to SA/V and at large values of $S A / V$ the slope of region 1 will increase much steeper than small values of $S A / V$.

Low values of $(S \mathrm{~A} / \mathrm{V}) *$ are analogous to the ambient conditions expected for the ISV/IEB waste form as unsaturated surface water percolated past the final waste form. Because the ISV/IEB final waste lorm will be in a near-surface environment where water thow rales will probably be relative high, saturation of the water may not occur and the forward rate of dissolution will limit the release rate. However, the $\mathrm{K}_{\text {, is }}$ strongly temperature dependent. Because of the high durability of the ISV IEB waste forms, it may not he possible to conduct leach tests at ambient ground temperatures $\left.(-2)^{\circ} \mathrm{C}\right)$ and have concentrations in the leachate above analytical detection limits. Conducting leach testing at higher temperatures $\left.(40)^{\circ} \mathrm{C}(0) 9()^{\circ} \mathrm{C}\right)$ will provide adequate leachate concentrations. II conducted at three or more temperatures, the $K_{+}$'s Arrhenius activation energy can be determined, which will allow the cemperature dependence to be esilablished and then calculate the $K_{+}$al ambient temperatures.

\section{B.3 Physical Durability Tests}

The physical durability of the final waste form can be evaluated using a variety of mechanical icisi mishotis. 


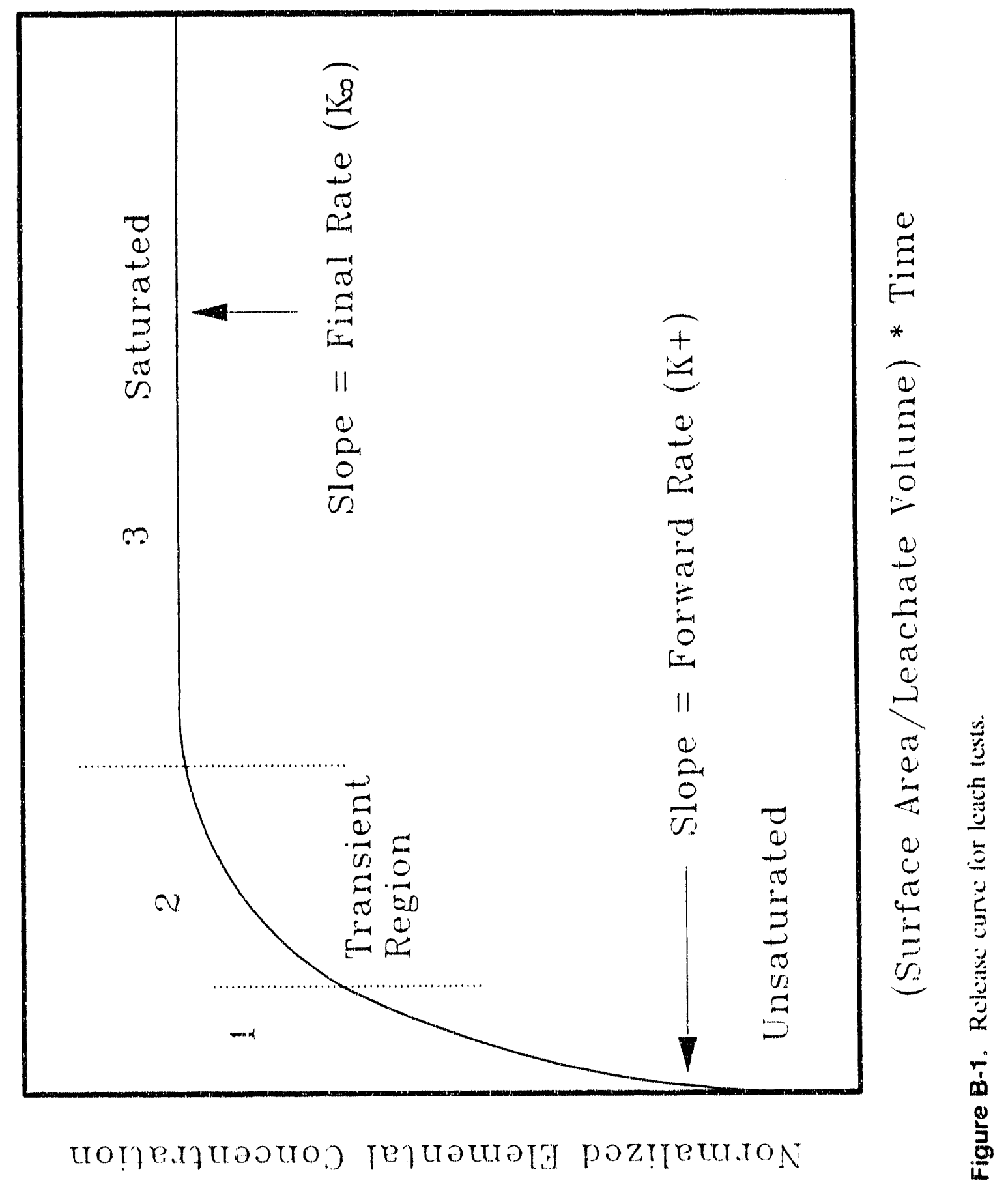

B. 10 
Impact Test

This test will reveal the resistance of the monolith during impact to generate breathable lines. This test is not applicable to small final waste forms such as water granulated marbles. This test would be necessary to satisly TRAMPAC requirements.

Bending Test

This test will reveal the fracture toughness of the final waste form. Either a three-point or a four-point bending test can be perform on the specimens $t$ ) measure the fracture toughness of the material. Large sampling of the bending test on core drilled specimens from different regions of the monolith will provide a statistical average of the fracture toughness of the final waste form.

\section{Indentation Test}

This test will reveal the hardness of the final waste form. Large sampling of indentation lest on core drilled specimens from different regions of the monolith will provide a statistical average of the hardness of the final waste form.

\section{Splituing Tensile Strength Test}

The splitting tensile strength test will give the maximum strength of the final waste form. This test is very sensitive to the surface condition and is a strong function of the surlace microcrack density.

\section{B.4 Radiation Durability Tests}

\section{Simulated Radianion Damage Test}

This test will provide the comparative resistance of the amorphous and the crystalline phases in the final waste form to atomic displacement and ionization damage due to internal radiation source eflects. To irradiate the final waste forms with high energy electron beams, gamma rays, and ion source can simulate the radiation damage tests. The internal radiation damage can produce bubbles, gas generation, atomic displacement, and ionization of the elements by high velocity radionuclides. These changes have important consequences for the durability of the final waste forms. 


\section{REFERENCES}

1. S. O. Bates, EGG-WTD-9184, August 199(), p. 15.

2. USEPA, Toxicity Characteristic Leaching Procedure (TCLP), 40 CFR 268, App. I, U.S. Federal Register, Washington, D.C., 1988, p. 728.

3. Nuclear Waste Materials Handbook, DOE/Tli-11400, Rev 7, Technical Information Center, Springficld, Virginia, 1986.

4. J. G. Carter, S. O., Bates, and G. D. Maupin, PNL-6174, Pacific Northwest Laboratory, Richland, Washington, 1987.

5. B. C. Bunker, G. W. Arnold, E. K. Beauchamp, and D. E. Day, J. Non-Cryst. Solids, Vol 58, 1983, p. 295.

6. N. Kawanishi, H. Igarashi, H. Nagaki, and Tsunoda, PNCT N831-80-()1, Power Reactor and Nuclear Fucls Corporation, Japan, 1980.

7. H. W. Chan and D. G. Howitt, Coramic Transactions, Vol 9, Nuclear Waste Management III, ed. G. B. Mellinger, 1990, p. 23.

8. R. C. Ewing and W. Lutze, Ccramic Transactions, Vol 9, Nuclear Waste Management III, cd. G. B. Mellinger, 1990, p. 33. 

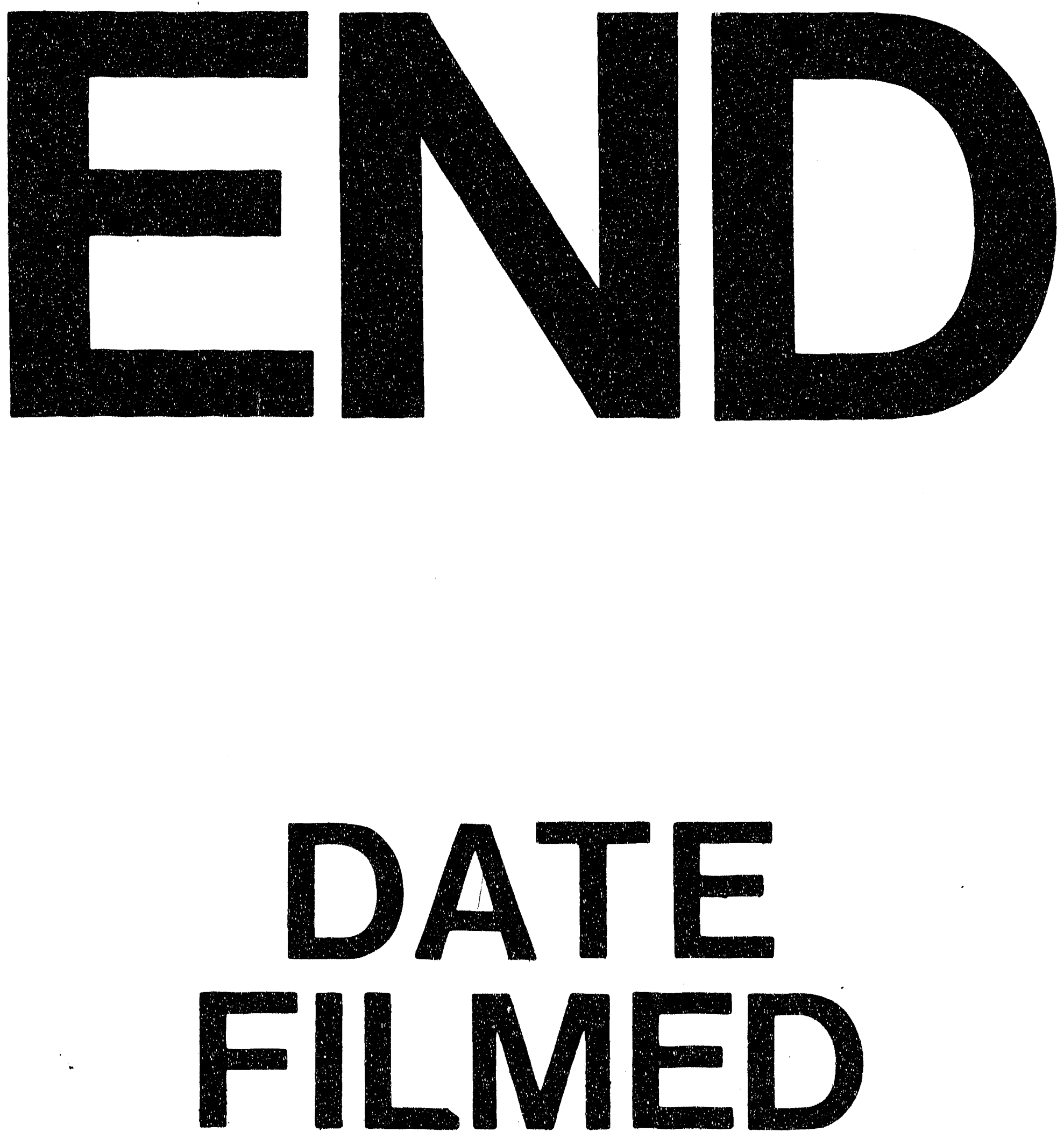

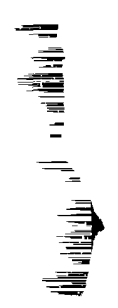

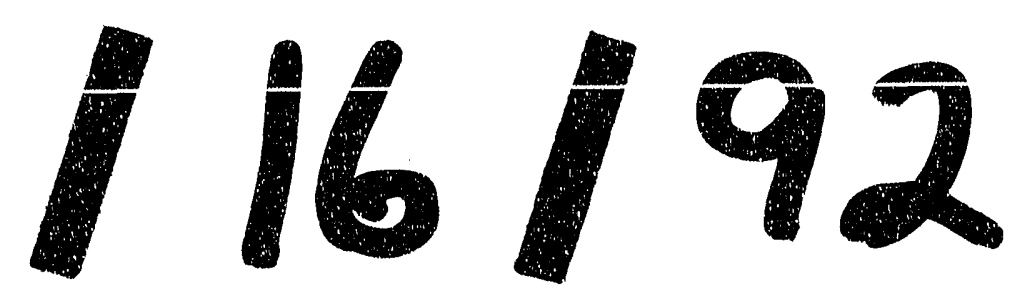




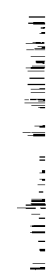

